\title{
Matrizes interacionais a comunicação constrói a sociedade
}

\author{
José Luiz Braga \\ Regina Calazans \\ Leon Rabelo \\ Caroline Casali \\ Michelli Machado \\ Paula Reis Melo \\ Rosana Zucolo \\ Ana Lúcia Medeiros \\ Pedro Benevides \\ Eloísa Klein \\ Monalisa Pontes Xavier \\ André Dornelles Pares
}

\section{SciELO Books / SciELO Livros / SciELO Libros}

BRAGA, J.L., RABELO, L., MACHADO, M., ZUCOLO, R., BENEVIDES, P., XAVIER, M.P., CALAZANS, R., CASALI, C., MELO, P.R., MEDEIROS, A.L., KLEIN, E., and PARES, A.D. Matrizes interacionais: a comunicação constrói a sociedade [online]. Campina Grande: EDUEPB, 2017, 449 p. Paradigmas da Comunicação collection. ISBN: 978-85-7879-572-6.

https://doi.org/10.7476/9788578795726.

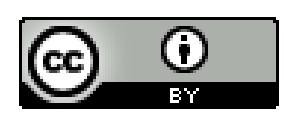

All the contents of this work, except where otherwise noted, is licensed under a Creative Commons Attribution $\underline{4.0 \text { International license. }}$

Todo o conteúdo deste trabalho, exceto quando houver ressalva, é publicado sob a licença Creative Commons Atribição 4.0. 
MATRIZES INTERACIONAIS
A comunicação constrói a sociedade 


\section{Conselho Editorial}

Presidente

Luciano do Nascimento Silva

\section{Conselho Científico}

Alberto Soares Melo

Cidoval Morais de Sousa

Hermes Magalhães Tavares

José Esteban Castro

José Etham de Lucena Barbosa

José Tavares de Sousa

Marcionila Fernandes

Olival Freire Jr

Roberto Mauro Cortez Motta

\section{Design Gráfico}

Erick Ferreira Cabral

Jefferson Ricardo Lima Araujo Nunes

Leonardo Ramos Araujo

Divulgação

Zoraide Barbosa de Oliveira Pereira

\section{Revisão Linguística}

Elizete Amaral de Medeiros

Normalização Técnica

Jane Pompilo dos Santos

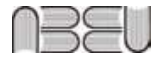

Editora filiada a ABEU

\section{EDITORA DA UNIVERSIDADE ESTADUAL DA PARAÍBA}

Rua Baraúnas, 351 - Bairro Universitário - Campina Grande-PB - CEP 58429-500

Fone/Fax: (83) 3315-3381 - http://eduepb.uepb.edu.br - email: eduepb@uepb.edu.br 


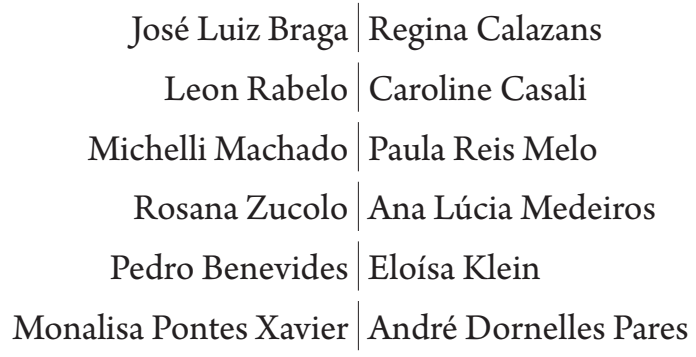

MATRIZES INTERACIONAIS
A comunicação constrói a sociedade

eduepb

Campina Grande - PB

2017 


\title{
Copyright $\odot$ EDUEPB
}

A reprodução não autorizada desta publicação, por qualquer meio, seja total ou parcial, constitui violação da Lei no 9.610/98.

A EDUEPB segue o Acordo Ortográfico da Língua Portuguesa de 1990, em vigor no Brasil, desde 2009.

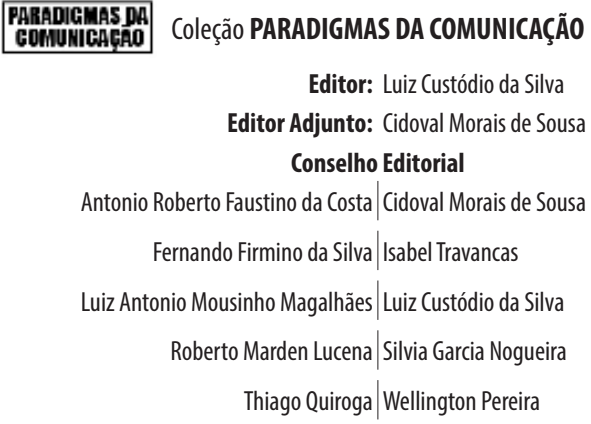

\section{Autoria: Grupo de Pesquisa Dispositivos \& Circuitos em Comunicação}

Depósito legal na Biblioteca Nacional, conforme decreto n0 1.825, de 20 de dezembro de 1907.

FICHA CATALOGRÁFICA ELABORADA PELA BIBLIOTECA CENTRAL - UEPB

M436 Matrizes interacionais - A comunicação constrói a sociedade. José Luiz Braga; Regina Calazans; Leon Rabelo et al. - Campina Grande: EDUEPB, 2017.

2100 kb. 452 p. (Coleção Paradigmas da Comunicação).

Modo de acesso: http://www.uepb.edu.br/ebooks/

ISBN 978-85-7879-449-1

ISBN E-BOOK 978-85-7879-450-7

1. Comunicação social. 2. Comunicação mediática. 3. Redes sociais. 4. Facebook. 5. TV. 6. Jornalismo. 7. Processos comunicacionais. 8. Interação social. I. Braga, José Luiz. II. Calazans, Regina. III. Rabelo, Leon. IV. Título. 


\title{
Nota dos EDitores
}

\begin{abstract}
A Coleção PARADIGMAS DA COMUNICAÇÃo tem como foco estudos que contemplem a comunicação social e midiática como constituinte da sociabilidade contemporânea, a partir de abordagens teóricas múltiplas dos diferentes campos de conhecimento.
\end{abstract}


1. Dispositivos Interacionais

José Luiz Braga

2. Circuitos de Comunicação

José Luiz Braga

3. 0 encaminhamento à pesquisa

José Luiz Braga

Parte II - Estudos Empíricos.

.85

4. Assange, Snowden, Greenwald .........................................................

Leon Rabelo

Suíte $n^{0} 1$ (JLB).

5. Redes sociais: um perfil no Facebook

Caroline Casali

Suíte $n^{0} 2$ (JLB)

6. Minisséries da TV: um circuito para a história

Michelli Machado

Suíte $n^{0} 3$ (JLB)

7. 0 fluxo comunicacional de ACERCADACANA

Paula Reis Melo

Suíte n ${ }^{\circ} 4$ (JLB).

8. TV \& Comunidades: um dispositivo em construção

Rosana Cabral Zucolo

Suíte nº 5 (JLB) 


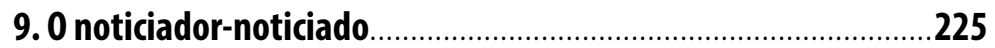

Ana Lúcia Medeiros

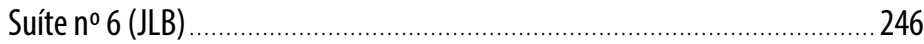

10. Jornalismo sob fluxos e ajustes: da autopercepção de

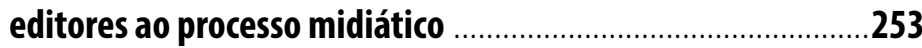

Pedro Benevides

Suíte $n^{0} 7$ (JLB)

11. As manifestações de junho, 2013: espalhamento e recriação midiática

Eloísa Joseane da Cunha Klein

Suíte no 8 (JLB)

12. Dispositivos "psi” midiatizados: a coluna Vida Íntima

Monalisa Pontes Xavier

Suíte no 9 (JLB)

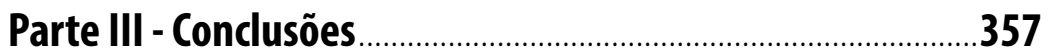

Conclusões: Inferências transversais ............................................359

José Luiz Braga e Maria Regina Zamith Calazans

Posfácio - Um diálogo com André Pares

A comunicação social como invenção, tentativa e experiência......409 André Dornelles Pares

A tentativa, a experiência .

José Luiz Braga

Bibliografia

Os autores. 


\section{Apresentação}

Os processos comunicacionais são habitualmente "perguntados” a partir de angulações sociológicas, econômicas, linguísticas, políticas (entre outras) - direcionadas por premissas daqueles campos. Diversamente, nosso enfoque busca perguntas e ângulos de observação mais próximos de preocupações comunicacionais.

Temos a premissa de que todos os processos sociais se desenvolvem tentativamente - a partir de problemas, necessidades e interesses inerentes ao próprio fato de compartilharmos o mundo da natureza e dos humanos.

Diante das questões sociais encontramos, historicamente disponíveis, padrões de interação para enfrentá-las - em comum ou em disputa. Os padrões estabelecidos se oferecem na experiência acumulada, seja na cultura geral, no acervo do senso comum ou no âmbito dos campos especializados em que a questão se forma. As regras pertinentes são então acionadas, assim como estratégias de ajuste à situação específica.

Se a experiência acumulada não oferece respostas, os participantes envolvidos são levados a interagir tentativamente - para testar ou inventar soluções. Na medida em que essa experimentação seja exitosa, sua lógica tende a ser reiterada em outras situações consideradas semelhantes, estabilizando, assim, os processos testados, como uma forma de invenção social.

Entendemos que também aqueles arranjos interacionais historicamente estabelecidos o terão sido por um processo idêntico. Inferimos, então, que um elemento importante na construção social são as estratégias interacionais, comunicacionalmente elaboradas para fazer coisas em comum (ou em disputa organizada) - que acabam gerando regras de comportamento, componentes da cultura e do senso comum. 
Tais padrões se mantêm como experiência consolidada - e são incorporados como modo de agir enquanto pareçam adequados e eficazes para as necessidades sociais. São modificados, reajustados ou substituídos sempre que, reformuladas as condições de contexto, se percebam menos eficazes. A esses conjuntos de padrões incorporados - comunicacionalmente produzidos - chamamos de matrizes interacionais. Nós as trataremos, neste livro, na forma de dispositivos interacionais ou de circuitos sociais.

Este livro, apesar de apresentar capítulos com autores individualmente nomeados, não é uma coletânea de artigos. A obra é uma produção conjunta do Grupo de Pesquisa Dispositivos \& Circuitos em Comunicação, com a composição indicada na capa (na ordem dos capítulos). Os trabalhos foram iniciados por um Seminário, em outubro de 2012, a partir da heurística, então em fase preliminar de elaboração, proposta por José Luiz Braga, coordenador do grupo. Um conjunto de quinze pesquisadores participou dos debates intensivos, trazendo suas propostas de temas para observação empírica, em que a heurística em estudo poderia ser usada como tática de abordagem, reflexão e busca de compreensão. Os objetos empíricos, em alguns casos relacionados a pesquisas então em andamento para dissertação de mestrado ou tese de doutorado, foram apresentados em formulação preliminar, com duas ou três páginas.

No Seminário, além da apresentação e debate geral sobre a heurística em desenvolvimento, cada questão de investigação empírica foi exposta e extensivamente debatida. Esse material foi transcrito e reunido na forma de anais (Seminário Dispositivos e Circuitos, 2012) - incluindo cada texto preliminar, seguido dos comentários, perguntas, objeções e sugestões dos demais participantes. Além 
disso, cada participante, após o seminário, apresentou por escrito questões e propostas sobre o texto de um(a) dos(as) colegas.

Depois desse movimento de partida é que os textos passaram a ser desenvolvidos. A pesquisa pessoal do coordenador do grupo teve continuidade, buscando, como era seu objetivo, uma formulação mais refletida da heurística em elaboração.

Os autores dos temas empíricos seguiram apresentando o avanço de suas pesquisas e seus estudos, acionando, no pertinente, os insumos do Seminário, além de suas investigações específicas. Esses capítulos, então como um trabalho em progresso, foram estudados por José Luiz Braga e por Maria Regina Calazans, levando a diálogos com os respectivos autores, o que resultou em reajustes e reformulações dos textos. Por outro lado, forneceram complementações para a heurística. Um bom exemplo - entre muitos outros - foi o desenvolvimento das articulações agora expostas (ver o segundo capítulo) entre as noções de dispositivos e de circuitos que, durante o Seminário, eram ainda pouco claras para nós.

Os nove estudos empíricos que fazem parte deste livro tratam dos seguintes temas: vigilância e segredos de espionagem; um perfil no Facebook; minisséries históricas; um filme documentário de denúncia social; grupos comunitários \& TV; jornalistas que são notícia; os circuitos digitais que atravessam o jornalismo profissional; as manifestações de junho, 2013; práticas "psi” na mídia. A diversidade de processos, produtos e situações é relevante, no estudo, para testar a abrangência da heurística; assim como sua capacidade de superar a dispersão pelo acionamento de perspectivas comuns.

Dois conjuntos principais compõem, então, a obra, se apoiando e repercutindo mutuamente. Na perspectiva da heurística, observase o caso empírico como oferta de processos concretos para o desenvolvimento dos aspectos comunicacionais que mostram aí 
seus indícios. Na perspectiva dos episódios estudados, a heurística tem a finalidade principal de funcionar como ângulo de observação para aprofundar uma percepção compreensiva (e não de reduzi-los por uma chave explicativa fechada). Isso significa que o episódio concreto sempre extrapola categorizações restringentes, devendo ser compreendido per se.

Embora os capítulos da obra sejam identificados pelas autorias individuais de cada responsável específico, devemos assinalar uma parcela significativa de autoria conjunta nos resultados finais, particularmente no avanço e na complexidade das proposições heurísticas. Enfatizamos que estas são fortemente devedoras do elenco de estudos e reflexões trazidos sobre os diferentes materiais empíricos aqui reunidos.

Agregamos no final do livro as referências propriamente bibliográficas - que são comuns a vários autores. Mantivemos junto aos capítulos as indicações de materiais relacionados a suas temáticas específicas de pesquisa.

Além do trabalho integrado e dialogal de que resulta a obra, outro movimento assegura a articulação interna do estudo. Ao final de cada estudo empírico, elaboramos reflexões específicas, repassando relações entre sua especificidade e os conceitos trabalhados, procurando, na observação relatada, estímulos para o desenvolvimento da heurística. Com isso, os comentários são próximos do observável tratado, mas iniciam uma prospecção modelizadora, como passo intermediário para subsequente tratamento transversal aos casos, de modo a testar e aperfeiçoar a heurística. Encaminham assim a reflexão para as inferências que aparecem na parte final do livro. Adotamos a denominação de "suítes" para essas reflexões articuladoras da sequência que vai dos estudos empíricos em direção às conclusões. 
Nas conclusões, baseadas nestes materiais e proposições, retomamos as reflexões, agora para obter aquelas inferências transversais e comparativas entre os diversos casos estudados - levando assim a conclusões mais abrangentes e lastreadas em referências de realidade. Com isso, se explicitam as contribuições que os capítulos empíricos trazem para a continuidade da reflexão sobre os processos comunicacionais em estudo, assim como o uso feito da heurística para o esquadrinhamento dos empíricos.

Acrescentamos, ainda, um Posfácio, com observações e questões postas por um dos participantes do grupo de pesquisa, André Dornelles Pares, seguidas de comentários pelo coordenador do grupo.

Este livro é oferecido aos interessados nos processos sociais em todas as áreas de conhecimento das Ciências Humanas e Sociais (e das práticas correlatas) - como uma heurística voltada para sua compreensão em uma perspectiva centralmente comunicacional. 
Parte I

Matrizes Interacionais 


\section{Dispositivos Interacionais}

José Luiz Braga

\section{Introdução}

Este estudo aborda dois grandes tipos de matrizes comunicacionalmente produzidas e exercidas: dispositivos interacionais; e circuitos de comunicação.

Os estudos da Comunicação geraram, no século XX, uma variedade de teorias que procuram apanhar o fenômeno, senão em sua totalidade, naquilo que parecia a seus autores ser o ângulo essencial da questão. Desde os anos 1990, entretanto, já não encontramos as ciências humanas e sociais muito focadas nesse objetivo - talvez porque foi sendo constatada a complexidade do fenômeno, sua diversidade de aspectos, sua presença em todos os contextos e em toda a processualidade humana.

Teorias continuam a ser propostas e acionadas, e pesquisas realizadas - entretanto, concentradas em ângulos específicos. No caso do Brasil temos um período rico em diversidade de questões e de abordagens que, desde a fundação da Compós ${ }^{1}$, mantém sua dinâmica. Efetivamente, como os encontros anuais da entidade o evidenciam, temos uma variedade de características sendo estudadas com intensidade. Este parece ser um bom caminho para o

1 Associação Nacional dos Programas de Pós-Graduação em Comunicação, fundada um 1991. 
conhecimento. Por outro lado, a diversidade de abordagens tem levado a uma dispersão de perspectivas (Braga, 2014).

Recusando a viabilidade e o interesse de uma teoria geral que pretendesse vencer a dispersão por uma sistematização de pretensão abrangente (que, inevitavelmente, excluiria aspectos), passei a me preocupar, desde 2008, não com explicações ou conceituação do fenômeno, mas com heurísticas que liberem a reflexão comunicacional de sistematizações próprias a outras CHS. Tenho estudado aspectos locais ou pontuais do fenômeno comunicacional, convencido de que nesse espaço de observação de ocorrências - no episódio, no caso concreto - é que melhor percebemos aspectos relevantes do fenômeno.

Com esse foco, minha pesquisa tem procurado articular o que já chamei de "teoria tentativa", no sentido de trabalhar com um pequeno conjunto de aspectos, com foco intermediário de abrangência, mas que permitisse observar uma boa diversidade de objetos, casos e situações em que a ação comunicacional seja vista como questão principal e ângulo prioritário para descobertas. Essa proposição se organizou com algumas metas principais:

- dar atenção central ao "comunicacional" sobre outros ângulos presentes (sociológicos, linguísticos, culturais, estéticos, educacionais, psicológicos, etc.), sem, entretanto, descartar esses ângulos - e sim os assumindo como caracterizadores de contexto ou como modalizadores;

- favorecer esse desentranhamento do comunicacional não por meio da busca de sua essência, mas sim da percepção de aspectos encontráveis na ocorrência do fenômeno, e que possam ser tomados como características comunicacionais;

- viabilizar, então, ângulos de comparabilidade entre casos e situações empíricas diversas, sem abstrair a diversidade, 
mas inversamente, permitindo que os aspectos em comum funcionem como referência - na situação empírica - para a compreensão do específico e do diverso.

Com tais perspectivas, a heurística em elaboração não se apresenta como uma teoria geral da comunicação, mas sim como a busca de uma teoria intermediária, ou de médio alcance (Merton, 1968) - voltada para um determinado subconjunto de aspectos do fenômeno geral "comunicação" - esperando gerar sentido e aprofundar a investigação sobre as situações em que as características aí articuladas sejam significativas. Essa perspectiva se justifica pela premissa de que a presença de um pequeno número de teorias intermediárias que se possam tensionar mutuamente parece ser, no momento, a melhor tática para enfrentar a dispersão, sem restringir a diversidade.

O conceito central de minha reflexão teórica é o de dispositivos interacionais, que procura dar sentido integrado às características de base. Por sua vez, a articulação comunicacional entre diferentes dispositivos viabiliza um segundo conceito, o de circuitos - complementar ao primeiro. Na perspectiva da Comunicação, apresentam-se como relevantes matrizes na construção social de realidade. Em artigos desenvolvidos entre 2011 e 2015², apresentei algumas perspectivas sobre esses conceitos e suas relações com a processualidade tentativa da comunicação, os aspectos de código e inferências, e sua composição na prática social. Este livro agrega, desenvolve e busca dar consistência a tais perspectivas.

2 Ver na Bibliografia alguns dos artigos publicados no período. 


\section{Premissas}

O fenômeno comunicacional se realiza em episódios de interação entre pessoas e/ou grupos, de forma presencial e/ou midiatizada. Essa é uma premissa relacionada à decisão de desenvolver conhecimentos comunicacionais não a partir de uma ontologia do fenômeno - como busca de sua essência conceitual - e sim da observação de características esquadrinhadas na prática cotidiana do processo, assim como por meio de heurísticas investigativas promissoras sobre o empírico. Assumindo que não há comunicação sem interação, podemos estipular que as interações sociais correspondem ao lugar em que podemos tentar nos aproximar do fenômeno comunicacional em sua ocorrência. As interações envolvem uma grande variedade de circunstâncias, processos, participantes, objetivos e encaminhamentos. De certo modo, cada episódio pode ser considerado singular, na sua existência histórica.

Na grande variedade de episódios interacionais de que participamos ou que observamos cotidianamente, nos episódios que investigamos em nossas pesquisas, e ainda naqueles que são relatados em estudos empíricos, vemos a comunicação como um trabalho de compartilhamento entre diferenças. Os motivos, os objetivos e os procedimentos podem variar indefinidamente, mas o processo de compartilhamento aparece sempre como um modo de enfrentar, resolver ou fazer agir criativamente as diferenças - para algum fim prático qualquer, para objetivos simbólicos ou distantes, ou ainda pelo simples jogo da interação.

A tendência, ainda encontrada, de pensar a comunicação como mensagem, apenas enfatiza produtos possíveis da comunicação, não observa a substância desta. Considerando, para os efeitos de nossa pesquisa, o trabalho de compartilhamento que a comunicação realiza, podemos afirmar sua característica performativa, 
qualquer que seja seu resultado, havendo ou não geração de um "produto" que concretize sua incidência, ocorrendo ou não compartilhamento equalizador (consenso ou acordo).

Essa busca de compartilhamento pode ter os mais diversos propósitos; e funciona ou não: constatamos também que o processo é sempre tentativo - seja em decorrência dos desafios impostos pela alteridade entre os participantes, seja pela complexidade do mundo e das questões processadas.

Assim, na observação de episódios interacionais, assumimos como "comunicação" não só aquela de valor alto, do processo bemsucedido ou da obtenção de consenso ${ }^{3}$ - mas toda troca, articulação, ou tensionamento entre grupos, entre indivíduos, entre setores sociais; frequentemente desencontrada, conflituosa, agregando interesses de todas as ordens; marcada por casualidades que ultrapassam ou ficam aquém das “intenções" (que, aliás, podem ser altas ou rasteiras). Pessoas se comunicam inclusive no conflito, na opressão ou na manipulação. Comunicação parece ser o processo voltado para reduzir o isolamento e para a ação conjunta entre humanos quaisquer que sejam os objetivos e os modos de fazer - admitindo, exatamente porque tentativos, que o ajuste e a sintonia são apenas aproximadamente previsíveis, geralmente de reduzida qualidade. A comunicação pode ser - e frequentemente é - canhestra. Mas é isso que precisamos entender como funciona, quais as margens de aperfeiçoamento possível; e quais os espaços em que é da própria imprecisão que se espera a flexibilidade para o humano e para o social. Pois é essa imprecisão mesma que, em algumas situações,

3 Esses critérios podem ser, é claro, adotados pelos participantes, conforme seus objetivos - mas serão parte do conteúdo da interação, e não condição sine qua non para caracterização do processo comunicacional. 
equilibra a opressão comunicacional e se põe como barreira última para o "pensamento único".

Esse processo determina uma diversidade probabilística complexa - até porque os critérios de "sucesso interacional" podem ser múltiplos, para uma mesma interação. Eles variam conforme as intenções dos participantes, a clareza dos enunciados, $\mathrm{o}$ atendimento de objetivos diversos, o equilíbrio ou desequilíbrio entre os participantes.

É preciso então não confundir "comunicação" com "comunicação bem sucedida" ou com "comunicação de boa qualidade". Menos ainda com um padrão extremo de controle dos resultados. É claro que valores altos e sucesso comunicacional devem ser compreendidos e buscados, assim como a seus critérios - mas devemos ter uma apreensão mais abrangente do processo, mesmo em seus "desvios", ineficácias, valores baixos, resultados canhestros, inclusive para compreender o que se define aí como valor.

Dois ângulos caracterizam a perspectiva de que a comunicação é tentativa. Pelo primeiro ângulo, os processos comunicacionais são relativamente imprecisos. As contribuições dos participantes são aproximativas - e sempre abaixo de uma possibilidade de desenho rigoroso. Com essa imprecisão, não se pode assegurar a qualidade dos resultados ou o sucesso do que é tentativamente desenvolvido. Para ponderar esse sucesso, é preciso apreender os próprios critérios internos, práticos, referentes aos resultados pretendidos no episódio.

Pelo segundo ângulo, os episódios comunicacionais são probabilísticos - significando que alguma coisa relativamente previsível pode acontecer. Por esse aspecto, então, devemos perceber diferentes graus de probabilidade, desde uma efetiva ocorrência de resultados 
até uma baixa ou nula realização. Certamente é possível estudar tais condições - mas não me refiro a estudos estatísticos ou cálculo de probabilidades, uma vez que não temos controle sobre a multiplicidade de fatores nem sobre suas incidências mútuas. Apenas observamos (justamente por essa impossibilidade de cálculo prévio) que bons resultados tendem a reforçar os comportamentos que, nas tentativas feitas, parecem estar em sua base.

Afirmar a comunicação como tentativa não corresponde a dizer que ela se realizará ou não, em uma postura "tudo ou nada" - o que levaria à simples confirmação da raridade de ocorrência de uma comunicação perfeita. Não parece haver, na sociedade, uma alternativa mutuamente excludente entre comunicação e ausência radical de comunicação. Essas duas possibilidades seriam apenas os extremos abstratos de uma dimensão contínua, com graus, níveis e direções variáveis de atingimento. Em síntese, a comunicação se exerce em uma ampla diversidade de graus qualitativos, de sucesso e de valor.

Não devemos, entretanto, fazer coincidir exclusivamente o "processo tentativo" com aquilo que o enunciador tenta obter em um episódio comunicacional - e que corresponde a sua eficácia em fazer passar aquilo que pretende (seja informação, proposição polêmica, interpretação, estímulo estético ou sentimento).

Certamente, o que devemos chamar de "tentativa do participante" é uma parte relevante de nossa tese. Essa tentativa se evidencia na busca de ajustar a expressão às condições de sua recepção; e ainda, na busca de obter uma interpretação da mensagem em coerência com o ponto de partida (emissão). A tentativa do participante receptor, por sua vez, seria a de interpretar em função de sua visada cultural, desmontando manejos ou sutilezas da mensagem que o possam enganar; e escolhendo, das mensagens, as que efetivamente lhe mereçam a sintonia, realizando a boa crítica. Mas tomar 
como critérios únicos de sucesso a obtenção de sintonia, pelo emissor, e a apropriação ativa, pelo receptor, sobre-enfatizaria esses dois polos - reduzindo o comunicacional aos objetivos particulares de suas partes, sem considerar o processo social mais amplo.

É importante para nossa tese assinalar que não só os participantes em uma interação acionam suas tentativas (e obtêm ou não sucesso, em diferentes graus e modos, conforme seus próprios critérios); também os processos comunicacionais, em perspectiva mais abrangente que a dos participantes, são tentativos.

Podemos então distinguir as tentativas dos participantes e as tentativas sociais que se atualizam a cada episódio interacional as tentativas de processo. As tentativas dos participantes (cada qual tentando ser bem sucedido em sua visada específica, na troca) se dão em um contexto processual no qual alguma coisa está em jogo. Dentro deste quadro, o participante tenta. O contexto processual não apenas organiza e desenvolve as tentativas diversificadas, como também diz o tipo de coisas que podem ser aí tentadas.

O modo básico pelo qual a sociedade faz essa organização de tentativas aparece na forma de geração de dispositivos sociais para a comunicação - uma produção social de dispositivos interacionais que articulam duas características básicas: a necessidade de "códigos" compartilhados entre os participantes; e o desenvolvimento de inferências.

\section{Componentes mínimos: códigos e inferências}

Dada a extraordinária diversidade dos episódios interacionais constantemente ocorrentes na sociedade - e a variedade de tipos de participantes, aspectos institucionais, objetivos compartilhados ou em processo polêmico, táticas acionadas, âmbitos sociológicos e culturais, e ainda suas relações com outros e outros episódios 
- como pensar seus processos e investigar sua ocorrência com uma preocupação específica sobre o comunicacional, na base dessa diversidade, em meio a essa dispersão?

Em nossa busca metódica dos processos mais simples e frequentes, encontramos dois componentes mínimos, que parecem estar presentes em todo episódio interacional: códigos e inferências ${ }^{4}$.

Em vários ângulos, é válido enfatizar na linguagem verbal seu aspecto de "código": no próprio conceito de "gramática"; em seu aspecto de "estrutura" prévia e profunda, que comandaria o discurso; na perspectiva de Saussure sobre a língua, como sistema autônomo diante da realidade; na relação da linguagem com o pensamento ("função expressiva", em que a linguagem funcionaria como organizador/tradutor); na articulação com as coisas do mundo ("função constativa", "função de representação", "função descritiva” - que tratariam do mundo em termos lógicos e/ou relacionados à verdade das afirmações).

Os estudos de linguagem, mesmo quando levam em conta relações de fluxo com o que não é código, frequentemente elaboram sua reflexão tomando a este como ponto de partida ou de chegada. Isso parece ocorrer também quando, ultrapassando o foco no verbal, tratam de outras substâncias - som, imagem, gesto. Procuram nestas, sobretudo, os elementos regrados, mesmo quando essas substâncias não autorizam mais que uma categorização de paracódigo às construções observadas. É assim, por exemplo, que se fala em uma "gramática da televisão".

Quando se trata, porém, dos usos da linguagem em situação concreta - da interação, da "fala" em perspectiva comunicacional a concentração nos aspectos da codificação já não parece suficiente.

4 Esta proposição é lastreada em pesquisa empírica sobre cem textos acadêmicos da área apresentados na Compós entre 2006 e 2008 (Braga, 2010c; Braga 2010d). 
Isso se nota claramente na teoria dos atos de linguagem. Os enunciados - que segundo Austin (1976), não são simplesmente "falsos ou verdadeiros", mas, em perspectiva performativa, "felizes ou infelizes" - não o são em virtude da clareza ou do rigor do código, nem de regras formalizadas, mas sim em função de seu relacionamento com as circunstâncias variáveis da situação concreta.

Assim, para o estudo da Comunicação, sem desconhecer a forte presença e o acionamento de elementos codificados em toda interação, e maiormente de para-códigos, devem ser enfatizados os processos mais sutis e menos controláveis, não codificados, que necessariamente se põem em marcha para integrar e completar toda e qualquer comunicação, por mais codificada que esta seja. Em suma: os processos inferenciais.

Em sua crítica ao "modelo do código", Sperber \& Wilson afirmam que "a compreensão implica mais que a decodificação da mensagem linguística” (1997, p. 189). Na sequência, propõem que:

há um abismo entre as representações semânticas das frases e os pensamentos realmente comunicados pelos enunciados. Este abismo não é preenchido por mais codificação, e sim pela inferência.

[...]

A pragmática deve explicar como os ouvintes resolvem as ambiguidades, como completam as frases elípticas, [...] como identificam as intenções de referência assim como a força ilocucionária, [...] enfim, como recuperam o que não é senão implicitamente comunicado (Sperber \& Wilson, 1997, p. 189 - as traduções são nossas).

Isso corresponde a afirmar que, no processo de produção e reconhecimento do sentido, os participantes de uma interação devem produzir hipóteses para, de modo inferencial, relacionar os 
enunciados com o que pode ser a intenção do falante e com a situação contextual em que os enunciados são feitos.

Fica claro que o código linguístico, mesmo no rigor de sua estrutura, é insuficiente para assegurar a comunicação social. Entre o código e o seu uso, incidem as condições extralinguísticas do mundo, do pensamento, das relações entre os participantes da interação, das conjunturas do episódio - que pedem um processo adicional ativo (inferências) para completar a comunicação.

Em outra obra (1979) Wilson e Sperber sugerem, para esse trabalho de recuperar a parcela de implícito, que a desambiguação e a determinação dos referentes podem ser subsumidas a um axioma: as inferências corresponderiam a um esforço de maximização de pertinência entre a interpretação e o enunciado. $\mathrm{O}$ que os autores enfatizam, aí, é a possibilidade de exercício de processos lógicodedutivos para ampliar a compreensão.

Em tal perspectiva, o inferencial parece estar a serviço do código - no sentido de apenas completar lacunas, de trazer os participantes ao melhor sentido codificado, ou de tornar explícitas as referências com o mundo. Diversamente, em nossa perspectiva, o processo comunicacional - que depende mesmo da presença de códigos como elemento necessário (isto é, de elementos compartilhados de referência comum entre os participantes) - não parece, entretanto, acionar processos inferenciais apenas para suprir lacunas e realizar ajustes. Além de efetivamente realizar estas ações requeridas, defendemos que as inferências desenvolvidas em um episódio interacional se mostram como o próprio núcleo da atividade comunicacional. É pelo jogo complexo e criativo de inferências exercidas mutuamente e em comum (embora não necessariamente em consenso) que a comunicação ocorre.

Embora a razão e a lógica sejam efetivamente processos muito interessantes de maximização do rigor (redução da imprecisão) e 
para a ampliação probabilística do sucesso na comunicação; é importante assinalar que nem todo "programa comunicacional" humano aposta principalmente nos controles voltados para a univocidade nem, correlatamente, na adoção de inferências lógicas relacionadas a códigos rigorosos. Os processos estéticos, como também os afetivos e os comportamentais práticos, tendem diversamente a procurar outros âmbitos de ação comunicacional - apostando antes em transações complexas e difusas, jogando justamente com a "tentativa” e a imprecisão na expectativa de gerar sintonias não baseadas na univocidade e sim na potencialidade de acordes compostos entre os participantes. A metáfora musical é adequada para sublinhar que a comunicação não é mera obtenção de identidade de vistas, mas composição complexa da diversidade humana.

Assim, os processos inferenciais, mais que um jogo lógico, são resultado de um problema prático para o qual os participantes devem oferecer soluções - que serão boas ou más; e que terão seus critérios direcionados pelas condições contextuais específicas. Por exemplo, em uma conversa de bar, uma reunião de epistemólogos, um debate parlamentar ou uma relação afetiva.

Propomos, então, inverter a relevância entre os dois elementos necessários para a comunicação. A inferência é o elemento central - que, no processo de aperfeiçoamento de suas táticas sociais e pessoais, desenvolve códigos (elementos compartilhados) que favoreçam e agilizem comunicações crescentemente complexas. Isso corresponde, também, a dizer que "códigos comunicacionais" abrangem, além da linguagem (verbal) e de "linguagens" (sistemas expressivos de diferentes ordens - particularmente audiovisuais, no mundo contemporâneo) uma grande variedade de processos, bastando que se exerçam como elemento compartilhado ou imediatamente compartilhável entre participantes: códigos propriamente ditos (de transposição), o algoritmo, as "gramáticas", o sistema da 
língua, regras e padrões sociais de comportamento, regularidades práticas, informações e referências em comum sobre o mundo. Desde que tais possibilidades sejam compartilhadas, qualquer que seja seu rigor ou precisão, já não estamos isolados comunicacionalmente - dependendo, é claro, de um acionamento de nossas competências inferenciais, sem as quais os códigos não se exercem ou funcionam mal.

O que referimos como "código" entre participantes da comunicação pode ir, então, desde o nível mais estrito de codificação (a transposição criptográfica) até o nível mais vago das referências em comum, passando por processos crescentemente flexíveis ou difusos. Em nível ainda mais elementar, há um aspecto básico de compartilhamento, não social mas biológico: pertencemos todos à mesma espécie. Partilhamos uma estrutura genética que fornece padrões de percepção e de ação sobre o mundo (Braga, 2015).

Em tensionamento com esses processos "de código", as inferências práticas correspondem, corriqueiramente, a um processo inferencial abdutivo. Para António Zilhão (2006), a abdução é uma "inferência para a melhor explicação" - com base nos dados disponíveis no momento em que se faz a hipótese. Isso quer dizer que a inferência abdutiva é sempre tentativa - pois não há limite para o acréscimo de novos dados e outros aspectos contextuais, assim como para a reinterpretação destes, que levem a reformulações da hipótese ${ }^{5}$.

Se a interpretação é necessária e variada mesmo nas trocas mais simples, é porque a comunicação não é feita só de acionamento de

5 É claro que, conforme os objetivos de uma interação, pode ser reforçado o interesse ou mesmo a necessidade de inferências indutivas ou dedutivas, para busca de univocidade. Acreditamos mesmo que tais modos inferenciais foram desenvolvidos a partir da competência humana "natural" para a abdução. A dedução e a indução aparecem como derivações daquela, voltadas para sistematização do rigor, sempre 
códigos - mas envolve, estruturalmente, uma parte de inferências abdutivas, não calculada em abstrato e não totalmente calculável nas situações concretas. Ou seja: não é possível regrar previamente a precisão nem a segurança das inferências. Não é possível estabelecer um super código que resolva todas as indefinições de código com relação à situação dada - pois este super código seria ainda tentativo e, por sua vez, pediria inferências de ajuste a cada situação singular.

As inferências não correspondem apenas à interpretação do sentido mais provável da manifestação recebida. Voltam-se também para o melhor ajuste dessa manifestação nas perspectivas e no acervo do receptor e para a continuidade do processo. Isso corresponde a dizer que não se pode pensar nas inferências inerentes aos processos comunicacionais como hipóteses que levam em conta apenas a "busca do melhor sentido" ou desambiguação da manifestação do falante. As "hipóteses para a melhor explicação" incluem referência a dados como, por exemplo, o acervo do participante-ouvinte, as condições contextuais e os objetivos da interação conforme o episódio interacional e suas "lógicas práticas". Incluem ainda a probabilidade de tensionamentos entre diferentes estímulos imbricados.

Interpretar o sentido de uma fala e ajustar esse sentido ao repertório do receptor não são dois aspectos independentes entre si. Assumimos que interpretação e ajuste reverberam mutuamente - ajustamos o sentido percebido, percebemos o sentido conforme os ajustes possíveis a nosso repertório. $\mathrm{O}$ resultado final desse jogo corresponde a que os episódios interacionais são inferenciais (logo, tentativos) no seu conjunto - pois se trata de obter algum tipo de

que o trabalho comunicacional seja assim favorecido. Mas sabemos como um diálogo baseado em lógica formal resulta emperrado ou ridículo em situações que não o exigem. 
ajuste em processo, entre todas as participações, e destas com seus contextos e seus objetivos, viabilizando uma ação em comum.

Por mais que tais processos sejam marcados por reduzida previsibilidade e pela imprecisão, é desse modo - tentativo - que as interações avançam e a comunicação, pragmaticamente, se desenvolve, com suas margens variáveis de ensaio-e-erro.

As inferências são certamente direcionadas pelos códigos existentes acionados: linguísticos, culturais, institucionais ou práticos; longamente estabilizados na sociedade ou constituídos ad-hoc a serviço de interações específicas. Mas estas também incidem sobre o código, por sua vez tensionando, solapando, assoreando. No longo prazo ou conforme a intensidade/novidade da situação, acabam por modificar ou criar novos códigos, por transformação ou superação (Braga, 2010c).

Simplificadamente, podemos dizer que a inferência é que permite atualizar o código, exercê-lo para além de um processo mecânico de codificação/decodificação, que não faria mais que transmitir informação - componente possível do processo comunicacional, é claro; mas nem de longe podendo caracterizá-lo como um todo.

Devemos notar, entretanto, que a maximização dos elementos "de código" (normatização) não significa necessariamente maior probabilidade e precisão; as regras podem levar também a sistemas fechados, sem flexibilidade interpretativa e de pretensão determinista. A abertura inferencial por sua vez, não significa necessariamente flexibilidade, espaço para a criatividade, democracia na participação; pode simplesmente reduzir a clareza, levar ao desentendimento ou produzir interações excessivamente dependentes do acaso.

Assim, além de valorizar o uso conjunto de códigos e de inferências para o processo comunicacional, devemos evitar uma 
interpretação simplificadora segundo a qual o código (verbal, cultural ou institucional) seria uma parte sólida, rigorosa; e a inferência, o componente tentativo meramente complementar. Embora no código (e conforme seu grau de abertura ou fechamento) as regras direcionem largamente os processos, os códigos são também tentativos - pois se produzem e desenvolvem através de interações concretas e pelas estratégias acionadas ${ }^{6}$. Isto é: se desenvolvem probabilisticamente, alguns prevalecendo sobre outros e ocupando a cena, enquanto outras tentativas de código fenecem; e funcionando, na prática, com graus variáveis de imprecisão - sendo por isso mesmo "aperfeiçoáveis" até certo ponto, segundo os critérios de suas próprias lógicas dinâmicas; mas também pelos embates que vão sofrendo a partir das condições concretas de uso (acionamento) e conforme as interfaces com as quais, socialmente, são levados a interagir.

Inferências e códigos são, assim, elementos com presença importante nos episódios e nos dispositivos interacionais que a sociedade desenvolve.

\section{Dispositivos Interacionais}

Se o processo da redução de ambiguidade, se o ajuste possível entre interpretações não coincidentes e a clareza de percepção dos referentes não podem ser subsumidos a uma regra geral (como a proposta de "maior pertinência", de Sperber e Wilson - que seria ainda um código pretendido determinista, ou então normativo); isso não significa, porém, que a cada episódio interacional os

6 Um pouco diferente da perspectiva sociológica (Bourdieu, 1990), não vemos estratégias apenas como variações de acionamento a partir de regras; mas também como processos práticos geradores de regras. 
participantes sejam obrigados a inventar e a desenvolver processos ad-hoc, inteiramente específicos e originais, a serviço de seus objetivos interacionais.

Constatamos, ao invés, a existência - socialmente produzida e disponível no ambiente cultural - de uma grande quantidade de táticas-padrão, de modelos reconhecíveis, mas com grande plasticidade de acionamento, que podem ser chamados pelos participantes a serviço de sua comunicação.

Denomino a esses modelos, para efeito de referência e conceituação, de "dispositivos interacionais". Para a conceituação inicial desse tipo de processo, amplio a noção de dispositivos sociais expressa em "A sociedade enfrenta sua mídia - dispositivos sociais de crítica midiática" (Braga, 2006). Nesse livro, trabalhamos exclusivamente dispositivos críticos. Agora tratamos, em geral, da diversidade de matrizes socialmente elaboradas e em constante reelaboração - que de um modo ou outro a sociedade aciona para poder interagir. No presente estudo, o que importa é a constatação de que tais dispositivos são elaborados através do processo mesmo de interações tentativas - que geram, por aproximação sucessiva, modos e táticas na busca de uma efetividade comunicacional ampliada, desenvolvendo, na prática, objetivos e critérios indicadores de sucesso. Os processos elementares que compõem um dispositivo interacional são inferências - solicitadas pelo aspecto lacunar das coisas compartilhadas; pela alteridade dos participantes; pela copresença de códigos diversificados; e pelas necessidades internas de produtividade da interação; e códigos - quaisquer elementos compartilhados entre os participantes e trazidos como base comum para a ação comunicacional destes. Um dispositivo interacional é um modelo desenvolvido pela prática experimental (tentativas) que conta com uma articulação mais ou menos definida 
de processos "de código" e de espaços não codificados solicitadores da inferência dos participantes.

A expressão "dispositivos" tem sido usada em uma diversidade de áreas de conhecimento, com sentidos variados. Tanto os objetos referidos como "dispositivos" se multiplicam; como a própria noção parece se moldar, plasticamente, a vários propósitos de reflexão. Frank Kessler (2006, p.1) assinala "a enorme variedade de campos em que o termo é usado de vários modos” (as traduções são nossas). Anota seu aparecimento nos anos 70, de modo independente, nas obras de Jean-Louis Baudry e de Michel Foucault.

Em entrevista feita em 1977, Foucault, perguntado sobre o sentido da expressão, responde:

o que eu tento apreender sob este nome é, primeiro, um conjunto resolutamente heterogêneo, comportando discursos, instituições, projetos arquitetônicos, decisões reguladoras, leis, medidas administrativas, enunciados científicos, proposições filosóficas, morais, filantrópicas, em suma: tanto o dito como o não dito - tais são os elementos do dispositivo. $\mathrm{O}$ dispositivo, mesmo, é a rede [o sistema de relações] que se pode estabelecer entre esses elementos" (Foucault, 1977; grifo nosso).

Sabemos que Foucault se preocupa, aí, sobretudo com dispositivos de controle, regulatórios. Assim, os tipos de elementos referidos são os que mais de perto dizem respeito a tais processos. Mas o sucesso da expressão "dispositivos" deriva antes de sua flexibilidade e transponibilidade para outros objetos e propósitos, do que de uma definição concentrada no foco foucaultiano - garantindose, entretanto, a percepção central de "sistema de relações". Como distinta da visada centrada no controle, Kessler assinala (2006, p. 4) a perspectiva de Michel de Certeau: "o conceito de dispositivo 
é explorado como um tipo de formação que não apenas produz controle e restrições, mas também abre possibilidades de contacto, participação, processos lúdicos, assim como experiências corporais e sensuais". Efetivamente, encontramos hoje uma variedade de "aplicações" outras - que levam a considerar elementos diferenciados (pertinentes aos propósitos do uso): dispositivos de percepção, de mediação, midiáticos, de aprendizagem, de conhecimento, de regulação, de tomada de decisão. De interação, acrescentamos - e esses são muito generalizados para toda ação humana conjunta.

Devemos assinalar que Foucault propõe, mais que uma visada sobre o controle, uma verdadeira "filosofia do dispositivo" (Deleuze, 1989). Dentro dessa filosofia, se preocupa com um tipo ou modo específico de dispositivos, os de controle. De nossa parte, fazemos referência à filosofia foucaultiana (complementada pela perspectiva de Michel de Certeau e por proposições de Maurice Mouillaud sobre matrizes), e não àquele objeto específico.

Trata-se então de refletir e observar os elementos interacionais mais pertinentes a nosso tipo de objeto; e sobretudo, de investigar o sistema de relações que entretêm. Assim, sem uma preocupação de definição preliminar, trata-se de ressaltar aspectos da noção que a tornam interessante. Um primeiro aspecto é justamente essa constatação do heteróclito - da reunião de aspectos heterogêneos que, de algum modo se articulam em um determinado processo social. Observamos que alguns destes elementos são da ordem da codificação (como a língua, por exemplo); outros são inferenciais. Nesse processo, ocorrem centralmente, em nossa perspectiva, jogos complexos entre elementos compartilhados de antemão (códigos); e elementos em processamento (inferências) que resultarão em outras partilhas - logo, ação e transformações.

Outro aspecto que deve ser sublinhado, no dispositivo, é sua contraposição a "estrutura" em sentido estruturalista - em oposição 
à imanência desta, prévia e determinante sobre o que nela é moldado. Com os dispositivos, o que temos é antes uma organização ad-hoc, prática, pragmática mesmo, que funciona enquanto funciona, recuperando portanto sua historicidade. Kessler enfatiza, no dispositivo, seu aspecto de "arranjo", de "tendência" (2006, p. 3). Podemos acrescentar que, enquanto a estrutura buscada pelo estruturalismo é fixa, prévia e profunda; um dispositivo é visto por seu estado "de superfície", expressando mais o próprio processo que um determinante. No dispositivo, a "organização" não é independente dos processos. ${ }^{7}$

Evita-se assim uma distinção forte entre estruturas e processos, que parecia ocorrer no estruturalismo. Por mais ancorada na tradição que seja uma "estrutura" (como modo de organizar e fazer funcionar as coisas), ela não é uma entidade à parte que - de fora comanda os processos. Entendemos que o aspecto "organizador" ou articulador dos dispositivos decorre historicamente dos processos. Processos reiterados tendem a se configurar como modos tendenciais para seu exercício continuado, logo como "estruturais" para o que se faça em sua esfera - ou seja: tornam-se padrões, regras, códigos, para-códigos. Para esse conjunto de atividades relativamente estabilizadas, ora mais tentativas, ora mais ancoradas em repetições e automatismos - creio que a denominação de "dispositivo" é adequada: modos de fazer socialmente produzidos e tornados disponíveis.

Além disso, em coerência com a constatação de elementos heterogêneos em articulação, os dispositivos têm sido vistos, em

7 Isso não significa que a organização dependa exclusivamente dos participantes imediatos. É claro que incidências institucionais, político-culturais e outras ocorrem intensamente - mas estas não são monolíticas nem extra-históricas. Sofrem, portanto, a pressão da própria interação. 
contraposição à ideia de instituições e regras muito definidos, como "ambientes de experiência” (GReMS, 1998): "Para além da questão da aprendizagem feita em dispositivos, põe-se também a questão da experiência feita dos dispositivos, enquanto constitutiva, em nossa sociedade, das conexões que mantemos entre nós, os outros e o mundo" (tradução nossa).

A apresentação do Colóquio "Dispositifs \& Médiation des Savoirs", do GReMS, assinala que a noção de dispositivo oferece um alargamento do quadro em que "a mediação dos conhecimentos tem sido geralmente apreendida: o livro, a escola, a biblioteca" (estes, mais propriamente institucionais). "Ao lado destes campos específicos [podemos] detectar outras formas e outros lugares em que os saberes se constituem: os gêneros televisuais, as exposições, os jornais, as revistas, os cibercafés, as multimídias [...]” GReMS, 1998, p. 2).

A constatação desse alargamento é interessante - mas devemos evitar a idéia simplificadora de que se trataria, aí, simplesmente dos "meios de comunicação", de suas tecnologias ou de suas formas mais bem sucedidas. Por mais pregnante que seja o elemento tecnológico, não é este que deve ser tomado como dispositivo interacional - mas o conjunto heterogêneo de materiais e de processos que não decorrem necessariamente da tecnologia, e que, sobretudo, podem dar direção e sentido a seu uso. Kessler observa, também, esse risco de excessivo foco no elemento técnico, que aparece na expressão em inglês adotada para o "dispositif" francês: "aparatus" (2006, p. 5) - razão pela qual adota, no título de seu estudo em língua inglesa, a expressão francesa - "Notes on dispositif". O sentido proposto de dispositivo, como "um quadro conceptual ou estratégico que torna possível um determinado fenômeno ocorrer" (2006, p. 2) aproxima-se bastante do que adotamos no início do presente 
item - matrizes socialmente elaboradas. Lembrando que a elaboração social se faz na prática das interações.

Por outro lado, o conceito é particularmente propício para estudos da mediatização - exatamente porque permite ultrapassar uma referência exclusiva aos "meios" (tecnologias, empresas midiáticas e/ou a forma de seus produtos) ou apenas às circunstâncias muito concretas e imediatas de sua apropriação (a relação "direta" de recepção) Tratar de "dispositivos" permite incluir as mediações que o usuário traz para a interação; as expectativas sobre o usuário, no momento da criação dos produtos - levando à "construção do leitor", aos modos de endereçamento, às promessas e contratos; permite incluir os processos em geral que cercam a circulação mediática; e aí também os contextos significativos de produção, de apropriação e da "resposta social" (sob qualquer forma em que esta ocorra).

Podemos então considerar que "dispositivos de interação" são processos e modos de ação, não apenas caracterizados por regras institucionais ou pelas tecnologias acionadas; mas também pelas estratégias, pelo ensaio-e-erro, pelos agenciamentos táticos locais - em suma - pelas atividades específicas da experiência vivida e das práticas sociais. Fica evidente, ao tratarmos de regras e de agenciamentos táticos, que consideramos os dispositivos interacionais como modelos muito diversamente compostos de códigos e inferências. Isso é evidente, aliás, na medida em que tais dispositivos são comunicacionalmente desenvolvidos e culturalmente acionados para o exercício de episódios interacionais - que já defendemos como sendo basicamente compostos por elementos de código, elementos de ordem inferencial e pelas relações complexas desenvolvidas entre estes.

O episódio interacional é o próprio dispositivo em momento de realização, caracterizado pela especificidade de seus elementos, 
seus objetivos e pelo sistema de relações comunicacionais constituído; modulado pelas circunstâncias de sua ocorrência singular. Nessa mesma linha, dispositivos referem episódios reiterados que elaboram um mesmo tipo de arranjo, exercido na prática comunicacional da sociedade. Uma mesma expressão pode designar tanto o episódio como o dispositivo. Por exemplo: aquela aula que dei ontem de tarde (episódio) é uma aula (dispositivo interacional) porque corresponde ao modelo socialmente reconhecido e acionado para esse tipo de interação. Dentro do modelo "aula", o episódio se desenvolve com suas especificidades próprias. A observação do sistema de relações desse dispositivo permite compreender os processos-tipo (do modelo acionado); as especificidades do episódio singular observado; e ainda, permite fazer observações comparativas com outros episódios de mesmo modelo; e com outros modelos - outros dispositivos - bastante diversos.

É também nesse sentido básico que podemos entender (com as variações decorrentes dos enfoques específicos) o núcleo conceitual que aproxima diferentes usos do conceito originalmente foucaultiano. Em todo caso, é nesse sentido que adotamos a expressão neste livro - assinalando ainda que estamos voltados para dispositivos que se organizam social e praticamente como base para comunicação entre participantes (em qualquer abrangência, número, dimensão ou processualidade). É nesse sentido abrangente que tratamos de "dispositivos interacionais"

É claro que, para o estudo empírico de tais "objetos", será necessário fazer opções, decidir que aspectos predominantes serão investigados no observável, conforme a problematização específica envolvida em cada pesquisa. Em síntese, selecionar. Ainda assim, o objeto mantém sua abertura, sua flexibilidade de acesso aos aspectos que sejam relevantes para a investigação - sem subsumi-la a dados pré-determinados por uma seleção apriorística (a forma do 
produto; a "linguagem", a empresa, a tecnologia, a mediação,...) que levaria a um esquecimento de elementos heterogêneos e das ponderações diversas que esses elementos podem ter em diferentes episódios.

Não se trata de classificar cada elemento percebido no episódio ou dispositivo como sendo "código" ou "inferência". Interessa antes observar processos, articulações, tensionamentos. Se percebemos elementos de código particularmente centrais, é claro que os destacaremos; se apreendemos incidências específicas de tais ou tais táticas inferenciais, será relevante observar sua ação. Nenhuma vantagem, entretanto, em fazer classificações - códigos e inferências não são categorias explicativas, são apenas processos que podem ser observados em suas lógicas específicas no caso em investigação.

Qualquer que seja o elemento "forte" selecionado pelas teorias adotadas e/ou pelo pesquisador, é importante considerar que suas incidências sobre o desenho do dispositivo se articulam com os demais elementos da interação. Isso corresponde a recusar uma ordem específica de elementos como necessariamente determinante dos demais - mesmo em casos assemelhados. A cada episódio, deve ser possível (a) perceber o que, aí, apresenta ponderação mais relevante; e (b) levar em conta, ainda assim, a presença e a incidência de outros fatores na composição específica.

Embora uma interação específica possa ser percebida como largamente "direcionada" por um dos elementos à escolha (a linguagem, os signos, as lógicas de empresa midiática, as características da tecnologia, o processo político-econômico, o peso da instituição, etc.); restam sempre composições diversas em outras interações de mesma linha. Mais ainda: é na sedimentação do que vai sendo tentado, testado e selecionado nas interações sucessivas de um dispositivo que ele mesmo se transforma, assim como a seus 
componentes - produtos, linguagens, lógicas, tecnologias e invenções de uso.

As proposições apresentadas neste capítulo devem ser percebidas prioritariamente pelo que solicitam do olhar pesquisador, bem mais que na simples assertividade do que dizem. Não são explicações apriorísticas sobre a realidade, mas sim ângulos para sua investigação em contexto. Os aspectos afirmativos são, então, proposições heurísticas - apenas assumidas como válidas para o efeito de busca de conhecimento.

Ao observar a realidade pela perspectiva de tais hipóteses de trabalho, deve-se buscar nas ocorrências empíricas (a que chamamos de "episódios" e "dispositivos"), os modos específicos daquilo que se afirma. Por exemplo: na afirmação de que "a comunicação é tentativa”, o que importa é observar que tentativas o processo interacional parece elaborar. Na percepção de que "a comunicação é transformadora”, é buscar o que é especificamente transformado, como, com que limitações. Uma questão válida para todas as afirmações seria: como isso ocorre? Caso efetivamente ocorra.

É apenas na obtenção de respostas interessantes para tais questões que a proposição heurística pode buscar sua sustentação.

No próximo capítulo apresentamos reflexões sobre um âmbito ampliado em que os episódios e dispositivos podem se desdobrar: o dos circuitos em que eventualmente se inscrevem, no processo de circulação comunicacional. Os dois conjuntos de proposições serão, depois, em um terceiro capítulo, observados por suas possibilidades heurísticas em apoio ao trabalho de pesquisa empírica. 


\section{Circuitos de Comunicação}

José Luiz Braga

\section{Introdução}

Ampliando a reflexão do enfoque sobre os episódios interacionais para sua inserção no espaço social geral, percebemos que as diferentes situações de interação frequentemente não se encerram em seus próprios objetivos e resultados. Potencialmente, onde termina um episódio interacional, inicia-se outro.

Isso significa que os resultados de uma interação se oferecem como matéria possível para outras interações. Essa matéria pode aparecer na forma de um produto (qualquer registro, como um texto, um vídeo, gravação sonora, anotações); ou ainda como memória, disponível entre os participantes, das falas, gestos e decisões que compuseram o próprio episódio. Sua existência, materialmente objetivada ou objetivável em narrativas possíveis, resulta em referências - pouco importa se principais ou secundárias - para outras interações, diretamente derivadas da primeira ou acionadas a partir de outros locais, participantes ou objetivos.

Os elementos de saída de um episódio (decisões, encaminhamentos, ideias sentimentos expressos, objetivos... ) se põem a circular, alimentando sucessivos episódios interacionais - que os relacionam, por sua vez a seus próprios processos e metas, inscrevendo-os em outros sistemas de relações e viabilizando novas inferências. Os objetivos, resultados e transformações repassados 
de episódio a episódio se apresentam como informação (elementos compartilhados ou imediatamente compartilháveis) ou como questões que pedem novas ações comunicacionais, nos episódios subsequentes.

A força da informação, em nossa abordagem (e nesse caso caracterizando-a como "código") é a de ser algo imediatamente compartilhável, podendo passar quase instantaneamente (na medida em que se ofereça para acervos de acolhimento em condições de abertura e acessibilidade para sua entrada) à situação de base compartilhada para interações - inclusive aquelas referentes à contestação de sua factualidade. Aliás, esta seria mesmo uma possibilidade de conceito de informação, em perspectiva comunicacional: é tudo aquilo que pode passar diretamente de um estado de não compartilhado para um estado de compartilhado. Sobre esse "compartilhado" se exercem, então, ações comunicacionais de ordem inferencial.

O processo de circulação não exige que o vínculo entre um episódio e outro, anterior ou subsequente, seja desenhado e constituído ad-hoc a cada processo de passagem. A sociedade elabora (sempre através de tentativas comunicacionais de criação, de ajuste e de aperfeiçoamento) processos mais ou menos reiterados de conexão e de tensionamento entre diferentes tipos de episódios - desenvolvendo assim lógicas articuladoras entre os dispositivos interacionais.

Essa reiteração de conexões entre diferentes dispositivos interacionais acaba se caracterizando como um circuito, que passa a direcionar explicitamente o fluxo comunicacional adiante, em determinadas condições contextuais. As expectativas de passagem entre episódios, na medida em que fazem reforçar as tentativas mais bem-sucedidas (na visada dos participantes) acabam por estabilizar e dar forma ao circuito, e por repassar indicativos aos próprios dispositivos interacionais. 
O circuito, uma vez constituído, pode ser então compreendido como uma base objetivada para aquilo a ser repassado como circulação "de mãos em mãos". A cada ponto nodal ou "estação" identificável, são realizadas ações interacionais, adjunção de códigos, geração de inferências - desenvolvendo portanto outros sistemas de relações entre os componentes aí articulados.

Ocorre, assim, sempre que temos um circuito instituído ou em experimentação social, um encadeamento de dispositivos interacionais parcialmente relacionados, podendo envolver manutenção, modificação, contraposição e acréscimo de ações, encaminhamentos e objetivos - de tal forma que o conjunto "circuito" elabora e exerce processos interacionais, repercutindo uma ação comunicacional em transformação, em fluxo contínuo. Lembrando que um mesmo dispositivo interacional pode estar inscrito em diferentes circuitos (ou trabalhar diferentes circuitos).

Em síntese: podemos considerar que circuitos comunicacionais são tendencialmente produzidos quando os processos e resultados (saída) de um dispositivo interacional de ação continuada ou frequente são de interesse para outros dispositivos que de algum modo trabalharão tais elementos como componentes de entrada para sua ação interacional.

\section{Circulação e circuitos}

Uma tendência frequente é a de pensar "circulação" como referência ao processo desenvolvido pelo produto midiático, da emissão à recepção. Nessa perspectiva, mensagem, informação, produtos da mídia circulam.

Eventualmente, considera-se um segundo movimento de circulação do produto, após a recep̧ção. Temos aí "respostas", novos produtos derivados dos primeiros, re-mediação, remakes, 
multimediação, cross-media. Todos esses processos evidenciam que o círculo do produto é bem mais amplo que a relação "curta" da emissão à recepção.

Minha perspectiva do "sistema social de resposta" (Braga, 2006) assinala ainda outro processo de circulação. Depois da recepção, e a partir de reações deste subsistema "de resposta social" (com suas mediações e "desvios" interpretativos próprios) o fluxo comunicacional não para e novos episódios interacionais, diferenciados, se iniciam: os que produzem leituras, objeções, debates, apropriações e desenvolvimentos em deriva. Um sistema de resposta social se desenvolve, repondo na sociedade (frequentemente através de processos midiatizados, mas também por ação direta) vozes que se posicionam e procuram agir comunicacionalmente - podendo, entre outras ações, exercer uma crítica da mídia. Eventualmente, estas ações retornam aos emissores originais, na continuidade de seu trabalho.

Em determinado momento, chegamos a considerar o sistema social de resposta como o principal elemento da "circulação comunicacional em sociedade de mediatização". Mas atualmente, em consequência de pesquisa continuada, derivamos outro espaço heurístico, dando maior abrangência ao conceito de circulação.

Trata-se de substituir a ênfase no "produto que circula" por uma percepção de circuito mais ampla - procurando enfocar a observação em nível mais abstrato. A comunicação social pode ser vista como um fluxo incessante de ideias, informações, injunções e expectativas que circulam em formas e reconfigurações sucessivas. Isso corresponde justamente às composições entre diferentes dispositivos interacionais e seus episódios, em que cada elemento de saída pode ser entrada para outra interação.

À diferença das interações conversacionais, o fluxo interacional abrangente em uma sociedade não se manifesta como ida-e-volta entre participantes. Na conversação (e seus variados dispositivos), 
o que se entende por "resposta" é uma fala que o receptor "devolve" ao emissor inicial, na forma de retorno. É frequente que se enfatize, na internet, essa capacidade de viabilizar retornos imediatos e pontuais sobre uma "fala inicial" - adota-se a expressão "interatividade" para expressar essa possibilidade. Embora esse processo efetivamente possa ocorrer, como componente relevante, entendemos que a circulação midiatizada articula, ainda, processos relevantes de outras ordens - tanto na internet como nos meios de massa.

Percebemos, então, um fluxo comunicacional contínuo $e$ adiante que dinamiza passagens de resultados entre dispositivos interacionais de ação frequente. Após a apropriação dos sentidos de uma mensagem originada em qualquer ponto da sociedade, seus captadores/apropriadores podem sempre pôr em circulação no espaço social sua resposta. Essa resposta, independente de um retorno imediato, segue adiante, em processos diferidos e difusos. Eventualmente, no conjunto da circulação e pelo embaralhamento cultural dos múltiplos circuitos, as ideias, proposições, imagens, posições polêmicas e tendências expressas se reforçam, se contrapõem, desaparecem ou retornam. O "retorno" que consideramos relevante nesse nível é aquele, difuso, do circuito ampliado e não a volta imediata ao ponto de partida.

Não devemos assumir a interação conversacional (ida-e-volta) como modelo geral para a comunicação social. Não cabe, por outro lado, excluir os dispositivos interacionais que correspondem a esse modelo, como potencialidade significativa para diferentes circuitos. Quando se enfatiza a observação de produtos nomeáveis tende-se a reforçar uma percepção restrita ao ambiente midiatizado (indústria cultural). Nosso objeto de reflexão e observação, em perspectiva comunicacional, é entretanto bem mais vasto e diversificado.

Embora a midiatização social tenha trazido uma acuidade perceptiva e uma intensidade operacional aos circuitos de comunicação, 
estes não se restringem nem aos produtos que circulam, nem aos momentos diretamente midiáticos. Na verdade, é importante, para uma compreensão aprofundada da comunicação social, observar os dispositivos interacionais não midiáticos que se interpolam nos circuitos, capilarizando a geração e a circulação de ideias, opiniões, atitudes, perspectivas sociais, propagação de códigos em compartilhamento - e tudo o que possa interessar, de perto ou de longe, à sociedade e a seus participantes.

Assim, é interessante não descurar dos momentos em que os dispositivos criadores e repassadores dos processos em circulação sejam de ordem conversacional, presencial ou a distância, públicos ou privados, que justamente, hoje, têm condições de não ficarem acantonados no vasto espaço "mudo" da recepção. Diversamente, podem interpolar sua fala no fluxo aparentemente mais vistoso e acelerado da mídia.

Nesse fluxo, o produto ocupa um lugar especial por sua materialidade e consequente facilidade de captura para observação e inferências. Mas, apesar dessa especificidade, o produto não é "o objeto inicial" de um percurso a ser seguido. Seria antes um "momento" (particularmente feliz, por sua materialização) de um circuito que começa antes e continua depois - passando a carregar a configuração que se formalizou no modo reconhecível de produto (ou seja: registro disponível e durável).

Isso permite perguntar a esse objeto mais percebido, que é o produto, como ele ocupa um lugar nesse circuito; que proposições recolhe e organiza; como reage sobre o que o antecede, o que produz nesse percurso e o que dirige "adiante", fazendo continuar a circulação.

Essa abrangência ampliada, entretanto, não caracteriza ainda o quadro completo do que assumimos como "circulação comunicacional" na sociedade. Entendemos que a comunicação social, na medida em que se amplia e se acelera pela midiatização social, se 
articula crescentemente à "escuta" e à produção centrada no polo receptor (Braga, 2007). Podemos começar a discernir aí uma espécie de retroação de sentidos, que vai da recepção à produção - ou mais exatamente: de cada ponto nodal subsequente ao ponto nodal antecedente. Não como "retorno de resposta", mas como previsão, pela auscultação anterior, da leitura que será feita daquilo que dizemos: uma antecipação.

Pela escuta, pela importância de "sintonizar" a recepção, pelas delicadezas de ajuste de endereçamento (nunca exato, sempre disperso e tentativo) alguma coisa retroage, "modificando" a interação e seus resultados a partir das expectativas sobre sua recepção e pela repercussão destas expectativas na configuração das falas. Cada "momento" da circulação, por antecipar os seguintes, procura se adaptar previamente a estes. Como assinalamos antes, esses momentos ou estações de um circuito correspondem aos episódios discerníveis (que acionam dispositivos interacionais socialmente produzidos).

É claro que esse "circuito inverso" existe desde sempre - mas se torna socialmente evidente em uma sociedade em midiatização. Mais que evidente: torna-se processo comunicacional inarredável, componente para o que quer que se faça ou se pretenda, comunicacionalmente, fazer. A tendência à serialidade que se evidencia na sociedade em midiatização favorece que as expectativas sobre os passos subsequentes de um circuito sejam aperfeiçoadas e ativadas para as novas "edições" dos passos anteriores. Nessa incidência retroativa, passamos a acionar interações a partir das respostas que pretendemos, esperamos ou receamos. Fica evidente a importância, para uma boa percepção das lógicas de circuitos, a observação da especificidade dos dispositivos que se relacionam, das lógicas de fluxos entre saídas e entradas - pois é nessa relação que o fluxo segue adiante e que antecipações se realizam. 


\section{Os sentidos da circulação}

Nas relações, agora percebidas como bem mais complexas, entre a produção e a recepção, o conceito de circulação - antes restrito ao intervalo entre os dois polos - ganha vigor e relevância, e acaba por extrapolar esses limites. Em "A sociedade enfrenta sua mídia”, afirmamos que

quando se trata de valores simbólicos e da produção e recepção de sentidos, o que importa mais é a circulação posterior à recepção. [...] O sistema de circulação interacional [em midiatização] é essa movimentação social dos sentidos e dos estímulos produzidos inicialmente pela mídia. (Braga, 2006, p. 28 - grifos no original).

Fausto Neto (2010b) assinala um desenvolvimento do conceito de "circulação" que, na medida em que se complexifica, se torna nuclear para pensar a midiatização da sociedade. Fazemos aqui uma apropriação do artigo, pelo ângulo em que estuda a sucessão de sentidos dados à expressão.

No período da ênfase nos meios, a circulação era vista meramente como a passagem de algo do emissor ao receptor. Uma preocupação central era a de verificar a consistência entre o ponto de partida e o ponto de chegada - o principal critério acionado era o da busca de correspondência e identidade entre emissão e recepção.

Com a percepção de que os receptores são ativos, a circulação passa a ser vista como o espaço do reconhecimento e dos desvios produzidos pela apropriação. Aparece então "como resultado da diferença entre lógicas de processos de produção e de recepção de mensagens" (Fausto Neto, 2010b, p. 10 - grifo nosso). Torna-se, portanto, um espaço de maiores possibilidades de ocorrência interacional, na prática social; e de descobertas, na investigação. 
Dada a possibilidade de desarticulação entre essas lógicas, por suas diferenças, coloca-se a questão de contratos para "descrever as possibilidades de construção de vínculos entre produção/recepção" (Fausto Neto, 2010b, p. 10). Uma pergunta relevante se volta para entender como a sociedade evita que as diferenças entre as lógicas da produção e as da recepção levem à simples incompreensão mútua.

A circulação é, então, "transformada em lugar no qual produtores e receptores se encontram em jogos complexos de oferta e reconhecimento" (Fausto Neto, 2010b, p. 11). Em nossa reflexão sobre dispositivos interacionais, "produtores" são quaisquer participantes de um episódio interacional que fornece elementos para circulação; e "receptores" são os participantes de outro episódio, que acionam aqueles elementos para suas ações comunicacionais.

Nesse estágio, "as lógicas dos contratos são subsumidas por outras lógicas de interfaces [...] os receptores perambulam por várias mídias, migrando em seus contatos com os mesmos, e quebrando zonas clássicas de fidelização". Fausto Neto reitera, ainda, em sua conclusão: "novas condições de circulação afetam as lógicas de instituições produtoras e sujeitos-receptores, por força da ambiência da midiatização" (Fausto Neto, 2010b, p. 12, 13 e 14. Grifos no original).

Podemos observar aí os desenvolvimentos sobre a relação produção/recepção. A partir desses entendimentos sucessivos sobre "circulação", mais um passo deve ser proposto: indo além das relações diretas entre produtor e receptor, importa o fato de que este último faz seguir adiante as reações ao que recebe. Isso decorre não apenas da presença de novos meios, mas também de que os produtos circulantes da "mídia de massa" são retomados em outros ambientes, que ultrapassam a situação de recepção (o espectador diante da tela). 
Esse "fluxo adiante" acontece em variadíssimas formas - desde a reposição do próprio produto para outros usuários (modificado ou não); à elaboração de comentários - que podem resultar em textos publicados ou em simples "conversa de bar", por exemplo, sobre um filme recém visto; a uma retomada de ideias para gerar outros produtos (em sintonia ou contraposição); a uma estimulação de debates, análises, polêmicas - em processo agonístico; a esforços de sistematização analítica ou estudos sobre o tipo de questão inicialmente exposta; passando ainda por outras e outras possibilidades, incluindo aí, naturalmente a circulação que se manifesta nas redes sociais.

Nesse fluxo, dois âmbitos de escuta ganham acuidade: uma escuta para apropriação dos resultados de episódios anteriores a serem acionados como elemento a ser processado em nova interação; e uma "escuta-expectativa" buscando prever a potencialidade de acolhida e tensionamento do que se dirá. Essa "intuição" de interpretações futuras não tem nada de adivinhação: na reiteração serial dos passos de um circuito, pode-se efetivamente observar reações dadas e fazer ajustes tentativos.

Nessas circunstâncias, já não é tão simples distinguir "pontos iniciais" e "pontos de chegada", produção e recepção como instâncias separadas. O que, aliás, nos faz perceber que tal construção decorre mais de uma condição histórica específica (a fase de implantação dos meios de massa) do que de uma pretendida "natureza" do processo interacional. A interação, pela própria etimologia da palavra, enfatiza antes a indistinção de papeis (ou distinções ad-hoc muito diversas) do que uma especialização "por estrutura". Ou seja: o exercício de diferentes ações, as assimetrias e opressões, devem ser relacionadas antes a cada tipo específico de interação - cada dispositivo interacional acionado - assim como a seus contextos significativos; e não a uma pretendida lógica diferencial no interagir. É 
claro que no caso dos meios de massa podemos distinguir claramente essas duas posições - que devem ser assim estudadas segundo suas lógicas específicas; mas evitando naturalizar estes papeis como se fossem categorias inelutáveis da midiatização. É consensual que, nas redes sociais, as diferentes lógicas interacionais definem outros papéis para os participantes. Mas mesmo nos meios ditos unidirecionais, uma vez absorvidos seus processos, culturalmente, pela sociedade e integrados a outros circuitos, a "diferença" deixa de significar necessariamente assimetria insuperável.

Por raciocínio complementar, se abordamos a circulação nessa visada abrangente, decorre daí que o produto mediático não é o ponto de partida no fluxo. Pode muito bem ser visto como um ponto de chegada, como consequência de uma série de processos, de expectativas, de interesses e de ações que resultam em sua composição como "um objeto para circular" - e que, por sua vez, realimenta o fluxo da circulação, como material de passagem entre as diferentes estações processuais, que são os episódios interacionais (e correspondentes dispositivos interacionais) dinamizadores da circulação. A rigor, não é "o produto" que circula - mas encontra um sistema de circulação no qual se viabiliza e ao qual alimenta.

Considerar a comunicação como um processo, como o fazemos, sugere que os dispositivos interacionais e seus episódios é que são os pontos nodais da circulação. O "produto", em sua percepção expandida, é antes um caracterizador dos elementos de saída e de entrada que relacionam dispositivos interacionais no circuito.

Por outro lado, o produto, como já indicamos, é um momento particularmente auspicioso da circulação - justamente porque, consolidado em sua forma que permanece (e que se multiplica, na sociedade em midiatização), pode continuar circulando e repercutindo em outros espaços. $\mathrm{O}$ produto, por sua permanência e também porque se molda ao mesmo tempo em que busca moldar 
os ambientes em que se põe a circular, torna-se um especial objeto de observação para inferências sobre os processos mais gerais em que se inscreve ${ }^{8}$.

Os processos e as consequências desse modo preferencial de circulação, próprio da sociedade em midiatização, devem então ser estudados. Uma questão que se põe aqui é a de como explicitar características dessa perspectiva abrangente, de modo a transitar da elaboração reflexiva e ensaística para o trabalho da pesquisa empírica. Uma primeira aproximação corresponde a perceber que essa circulação em fluxo contínuo não é apenas uma descrição abstrata. Ela se manifesta concretamente na sociedade, na forma dos circuitos culturalmente praticados, reconhecíveis por seus usuários e que podem ser descritos e analisados por pesquisadores. Os dois próximos itens pretendem concretizar minimamente esse conceito, como base para investigações específicas.

\section{Circuitos versus Campos}

Os circuitos não se desenvolvem no vazio. Há uma sociedade pré-mediática solidamente instalada por suas instituições e estruturas historicamente elaboradas. Um bom modo para tratar esse ambiente estabelecido é referir os campos sociais, conforme a perspectiva de Bourdieu - estudados como "microcosmos relativamente autônomos":

Uma das manifestações mais visíveis da autonomia dos campos é sua capacidade de refratar, retraduzindo sob uma forma específica as pressões ou

8 Em uma abordagem de dispositivos e de circuitos interacionais, podemos observar o produto (conforme sua inserção na circulação) indo além de sua expressão e conteúdos - como conjunto de indícios para fazer inferências a respeito dos dispositivos e dos circuitos de que participa. 
demandas externas. [...] quanto mais autônomo for um campo, maior será seu poder de refração e mais as imposições externas serão transfiguradas, a ponto, frequentemente, de se tornarem perfeitamente irreconhecíveis. (2003, p. 22. Grifo no original)

Adriano Rodrigues propõe que "um campo social constitui uma esfera de legitimidade" (1990, p. 143). Observando que "cada um dos campos sociais coexiste com uma multiplicidade de outros campos, compondo entre si [...] as funções expressivas e pragmáticas e as formas simbólicas de visibilidade" (idem, 149), Rodrigues oferece, em 1990, uma boa percepção sobre a instauração do "campo dos media" na sociedade. De modo pertinente para o que ocorria ao final da década dos 80 , propõe que

a legitimidade do campo dos media é de natureza predominantemente vicária ou delegada. A fonte da sua legitimidade resulta de um processo de autonomização de uma parte das funções de mediação dos outros campos sociais, autonomização exigida pelo processo generalizado de disseminação das esferas da experiência no mundo moderno. (idem, p. 155).

Entretanto, na sociedade em midiatização, já não se podem restringir os processos sociais a essa inclusão de um campo especial, através da cessão de mediações pelos outros campos ao campo mediático. Em nossa aproximação do conceito, resistimos à perspectiva de que a midiatização da sociedade apenas decorra da "ação dos meios", seja pela incidência da indústria cultural ou como decorrência direta da inovação tecnológica, ou da ação dos ambientes institucionais/profissionais que, em torno de tais processos, caracterizariam o "campo dos media". 
É certamente válido fazer referência a um "campo dos media", restrito, entretanto como um dos espaços - aquele do delineamento institucional/profissional mais evidente, e para o qual as universidades principalmente oferecem sua formação em Comunicação. Mas esse campo não é "o responsável" pela midiatização da sociedade, senão na medida em que todos os campos sociais igualmente o são, cada um com suas incidências específicas. Fausto Neto considera que

já não se trata mais de reconhecer a centralidade dos meios na tarefa de organização de processos interacionais entre os campos sociais, mas de constatar que a constituição e o funcionamento da sociedade - de suas práticas, lógicas e esquemas de codificação - estão atravessados e permeados por pressupostos e lógicas do que se denominaria a "cultura da mídia". (2008b, p. 92).

O surgimento de modos diversificados para interagir na sociedade, a intensidade da circulação simbólica, o surgimento de articulações e de fricções onde anteriormente os processos principais podiam ser conduzidos pelas lógicas de campos específicos e por negociação em zonas de fronteira entre campos - tudo isso leva à necessidade de processos experimentais pela sociedade em sua abrangência.

Seja para fazer de outro modo as mesmas coisas, seja para acionar processos antes não viáveis (ou talvez sequer pensáveis), todos os setores da sociedade são instados, pela própria predominância da midiatização "como processo interacional de referência" (Braga, 2007), a se articularem através de circuitos pouco habituais. A midiatização geral da sociedade torna inevitável a continuidade entre processos mediáticos e outros processos interacionais de sociedade - que se relacionam crescente e diversificadamente com as interações midiatizadas. 
O uso de processos tecnologicamente acionados para a interação já não é mais um "fato da mídia” (campo social) - assim como a cultura escrita não é um fato das editoras, dos autores e das escolas, exclusivamente. Esses dois grandes processos culturais (hoje com fortes interpenetrações) são antes de tudo fatos comunicacionais da sociedade.

Cada setor ou processo de sociedade participa de circuitos múltiplos. Com a midiatização crescente, os campos sociais, que antes podiam interagir com outros campos segundo processos marcados por suas próprias lógicas e por negociações mais ou menos específicas de fronteiras, são crescentemente atravessados por circuitos diversos.

A cultura comunicacional mediadora passa a ser caracterizada por tais processos fortemente tentativos. O que importa assinalar, em nível distinto das observações genericamente recusadoras ou deslumbradas, é que a passagem do estranhamento à absorção como cultura não se faz apenas por uma "habituação" - mas sim, fortemente, por invenção social. A cultura da midiatização em implantação se faz por experimentação. É claro que processos inventados socialmente e historicamente tornados vigentes podem resultar valoráveis ou negativos - e geralmente são, de modo tensionado, bons ou maus conforme as circunstâncias - o que significa que devem ser criticados com especificidade.

Os diferentes campos sociais, no seu trabalho de articulação com o todo social, desenvolvem táticas e usos para as tecnologias disponíveis, moldando-as a seus objetivos. Ao experimentarem práticas mediáticas, ao se inscreverem, para seus objetivos interacionais próprios, em circuitos midiatizados, ao darem sentidos específicos ao que recebem e transformam e repõem em circulação - os campos sociais agem sobre os processos, inventam, redirecionam ou participam da estabilização de procedimentos da midiatização. Essa processualidade 
interacional inevitavelmente repercute sobre o próprio perfil do campo - por exemplo, incidindo sobre o equilíbrio das forças que o desenham em dado momento, abrindo possibilidades para determinadas linhas de ação e fechando outras, exigindo diferentes tipos de ajuste ao contexto. Mas isso também requer invenção social.

Além dessas "ações institucionais" de ajuste do próprio campo ao ambiente midiatizado, ações "novas" se desenvolvem no contexto, que remetem a desafios antes não acionáveis e para os quais não há respostas prontas. Algumas dessas ações são diretamente "subversivas", como assinala Victor Folquening (2011) - correspondendo à possibilidade de agentes externos a um campo social (inclusive agentes individuais) produzirem incidências sobre um campo estabelecido a partir de pontos externos a este, uma vez que consigam estimular circuitos e dispositivos interacionais tentativos, encontrando ressonância no próprio campo ou em suas áreas de entorno. Isso pode ocorrer porque todos os campos sociais, na sociedade em midiatização, parecem estar mais atrelados a necessidades de interação "externa", mesmo à custa de não poder impor suas próprias lógicas para dizer "suas coisas".

Paralelamente, determinados agentes com posição interna em um campo social - e utilizando o capital social aí amealhado - passam a interagir com o ambiente externo fora das lógicas estritas mais habituais desse campo, acionando processos e lógicas diferidos e difusos, próprios da midiatização. Mesmo quando tais processos de circulação encontram uma recusa crítica por parte dos grupos definidores e controladores das "lógicas do campo" (no estado atual do jogo de forças), o capital social anteriormente acumulado por aqueles agentes, complementado pelos capitais da "aceitação externa", modifica os sistemas de relações internos.

Por todas estas razões, a capacidade de refração dos campos se encontra inevitavelmente diminuída, em todo caso "deformada" por 
comparação ao desenho estabelecido. Outra maneira de expressar isso seria considerar que a "esfera de legitimidade" estabelecida pelos diferentes campos sociais se encontra agora constantemente em risco, devendo ser continuadamente reconsiderada e reelaborada.

Exemplos podem se multiplicar - basta observar a incidência das aprendizagens não-controladas pelo campo educacional; ou a difusão de falas em modo diferido e difuso com relação a campos que asseguram, habitualmente, um contato controlado entre seus especialistas e o público atendido (como é o caso da medicina e do campo psicológico). Mesmo no espaço profissional estabelecido da comunicação social (os meios institucionalizados e o exercício das "profissões da comunicação social"), observamos a incidência de uma sobremidiatização, quando diferentes pessoas e instituições envolvidas em fatos de atualidade se deslocam da situação de "fonte" (isto é, de fornecedores de uma informação que deve ainda passar pelo crivo interpretativo-seletivo de um jornalista) para uma posição de informadores "diretos", com base em uma reivindicação de credibilidade por se vincularem diretamente ao acontecimento relatado.

São apenas exemplos - mas parece suficiente para esclarecer nossa proposição. Não estamos sugerindo que os campos sociais se diluirão em favor de uma espécie de "comunicação direta" da sociedade através de redes difusas. Mas afirmamos que as mudanças decorrentes de processos de interação "em midiatização" modificam (e modificarão crescentemente) o perfil, os sentidos e os modos de ação dos campos sociais; que outros campos se desenvolvem; e sobretudo que os modos de interação entre os campos sociais, e entre cada um destes e a sociedade ao largo, correlatamente se modificam.

Pelo menos até que, eventualmente, após um período de forte experimentação social, aos poucos se desenvolva algum tipo de 
estabilidade de processos, nosso foco de estudos envolve estarmos atentos para esses aspectos "tentativos". Devemos enfatizar que, embora esse impulso de experimentação estimule certamente a inovação tecnológica, essas tentativas se demarcam sobretudo como buscas de procedimentos de interação - e portanto, como geração e seleção constante de dispositivos interacionais 9 .

É nesse âmbito de processos - de natureza comunicacional que muitas questões sociais se encontram em jogo. Estudar circuitos é relevante para compreender a sociedade em midiatização - justamente porque não prevalecem aí, simplesmente, as lógicas deste ou daquele meio, nem mesmo as lógicas preferenciais de determinados tipos de meios. Assim, não é interessante contrapor os meios digitais aos meios de massa como se fossem caracterizadores de mundos diferentes. Cada circuito compõe diferentes articulações entre o massivo e o digital, engastando ainda, aí, o presencial e a escrita.

\section{Para fazer inferências}

Pode-se perceber, na continuidade entre as duas noções, de dispositivos interacionais e de circuitos da comunicação, que não há uma diferença de natureza entre os dois objetos. A diferença corresponde, antes, à abrangência - de composição e de extensão - do processo comunicacional que queremos investigar; assim como ao enfoque e à problematização adotados pelo pesquisador.

Se nos concentramos em episódios para examinar sua lógica interna de processamento, para nos perguntarmos sobre o sistema

9 Não é demais lembrar que "dispositivos interacionais” não são aparatos tecnológicos: são sistemas de relações interacionais mais ou menos estabilizados - são modos práticos disponíveis na cultura. 
de relações que articula os participantes mais imediatos, uma abordagem pelo modelo de dispositivos interacionais (acionados ou em construção) deve ser mais produtiva.

Se observamos uma situação mais ampla e diversificada, em que o interesse e o questionamento se voltam antes para os resultados e insumos relacionados a diferentes dispositivos discerníveis, observando as passagens entre processos diferenciados - então a abordagem a partir de circuitos pode se evidenciar como mais interessante.

Em pesquisas complexas (e assumindo um trabalho de equipe e/ou maior tempo de dedicação pessoal), pode ser relevante articular o estudo de um circuito e o das lógicas específicas que caracterizam alguns dos dispositivos que o compõem.

Nos debates entre os autores deste livro, desde o primeiro momento de elaboração, em 2012, percebemos que alguns temas escolhidos se prestavam mais facilmente a um enfoque na perspectiva dos dispositivos interacionais; enquanto outros se mostravam mais adequados a uma abordagem pela observação de circuitos mesmo não tendo, então, maior clareza sobre as relações entre os dois ângulos, que só depois desenvolvemos na sequência.

Não se trata de objetos radicalmente diferenciados no âmbito da comunicação social, como percebemos pela introdução da noção de circuitos. Que um estudo empírico adote preferencialmente um ângulo ou outro parece ser decorrente da formulação do problema a pesquisar - levando a que se concentre na especificidade de um episódio, ou tipos de episódios; ou que, diversamente, peça maior atenção sobre os processos e lógicas de encadeamento social produzidos para passagens (saídas e entradas) de dispositivo a dispositivo. Se estudarmos o circuito, perceberemos em visada mais abrangente ou transversal os diferentes dispositivos (episódios) que o constituem ou aí exercem uma incidência. 
É claro que no estudo de circuitos, malgrado a ênfase nos processos de passagem, é possível também dar uma atenção ao que ocorre em cada estágio interacional "entre passagens", ou seja, nas estações em que um tipo de episódio exerce suas próprias lógicas. De modo correlato, nada impede que, no estudo de determinado dispositivo interacional, se observem elementos de entrada e saída, buscando-se, para maior compreensão de episódios de interação, indicações sobre o que os inscreve em tais circuitos.

Dada essa contiguidade entre os dois conceitos (e entre os objetos correspondentes), entendemos que premissas e características assinaladas no primeiro capítulo, relacionadas ao fenômeno comunicacional, mantêm todo seu interesse para o estudo dos circuitos. Assim, na problematização, na descrição e na produção de inferências sobre estes, deve ser necessário observar:

- as tentativas processuais encaminhadas;

- as ações desenvolvidas, em sua performatividade;

- as diferenças que entram em contato, no fluxo; e o trabalho comunicacional associado a essas diferenças, seja na produção de acordos, na negociação ou na explicitação das distâncias e oposições;

- as transformações internas ao circuito, através das passagens entre suas estações (que são os dispositivos); ou relativas às lógicas de conjunto do circuito;

- as configurações práticas resultantes da adjunção entre dispositivos diversos em seus processos de escuta, de encaminhamentos complementares e de tensionamentos mútuos;

- o trabalho de acionamento de códigos compartilhados, de espaços abertos para inferências, de invenção necessária de códigos e de seu direcionamento no fluxo; 
- as modulações que incidem no fluxo conforme sua passagem por dispositivos de âmbitos e campos sociais diversos, assim como a incidência do próprio circuito sobre tais campos.

O objetivo da heurística aqui trabalhada é então o de viabilizar investigações sobre processos muito diferenciados de circuitos, na sociedade, percebendo suas lógicas comunicacionais para apreender similaridades e diferenças entre tais processos.

Esse trabalho descritivo e inferencial se propõe como investigação sobre toda uma diversidade de processos sociais segundo uma perspectiva comunicacional - ou seja

a. um enfoque que atribui centralidade a aspectos do fenômeno social sobre outras perspectivas focalizadas pelas CHS, favorecendo o desentranhamento de um conhecimento propriamente comunicacional;

b. e que procura derivar daí uma percepção de como o fenômeno comunicacional, por suas características próprias, se articula com outros processos e objetivos da sociedade - educacionais, políticos, psicossociais, culturais, etc. ao mesmo tempo viabilizando seus encaminhamentos e sendo aí modalizado.

Não sabemos ainda com precisão a abrangência possível desse instrumento metodológico e heurístico, nem seu alcance em produtividade de conhecimento - o presente livro representa uma experimentação e um teste, no sentido de obter maior precisão nesses aspectos, mas o alcance e o desenho da pertinência só se desenvolverão na medida de um eventual uso diversificado pela área. 
No momento, percebemos, pelas perguntas viabilizadas nesse âmbito heurístico, que a abordagem favorece uma compreensão de episódios interacionais e de circuitos sociais em dois níveis:

a. para apreender lógicas de relações interacionais bastante estabilizados na prática social;

b. mas também para inferir lógicas em vias de constituição - experimentação de processos, tentativas sociais de elaboração de dispositivos e de circuitos - ou seja, para capturar, ainda em curso de desenvolvimento, o que chamamos de "invenção social na e pela comunicação".

Esse segundo nível nos parece particularmente relevante, na medida em que as ações de midiatização generalizada, na sociedade, têm estimulado uma forte experimentação de dispositivos e de circuitos.

No presente livro encontramos entre os capítulos de observação empírica tanto processos estabilizados como experimentações sociais que, exatamente porque "em elaboração", evidenciam explicitamente a centralidade do comunicacional nessa construção tentativa.

No próximo capítulo, antecedendo a apresentação dos nove casos empíricos em que as presentes reflexões são testadas e foram aperfeiçoadas, fazemos indicações sobre o acionamento possível da perspectiva comunicacional para o trabalho de pesquisa. 


\section{0 encaminhamento à pesquisa}

José Luiz Braga

\section{Introdução}

Afirmamos, desde o primeiro capítulo, a preocupação de que nossas proposições não se apresentem com pretensão explicativa das características do fenômeno comunicacional. Certamente posições são tomadas, premissas são assumidas, características são elaboradas. Mas evitamos uma caracterização da realidade que pretenda estabelecer processos aprioristicamente classificadores ou determinados de antemão por relações genéricas de causalidade.

Nesse sentido, podemos afirmar que as reflexões feitas se colocam em perspectiva heurística - como estímulo e apoio ao trabalho de investigação e descoberta sobre realidades múltiplas em que vemos a comunicação humana e social se exercer.

Em variadas discussões preliminares sobre os conceitos aqui propostos, ouvimos a seguinte questão, posta em diferentes formulações: como usar essa perspectiva a serviço da pesquisa empírica?

A questão se justifica, pela frequência de aplicação de teorias por sua característica de explicação de uma realidade geral, em que se faz simplesmente entrar o objeto específico pesquisado nas categorias lá estabelecidas ou em que se busca apenas explicar os efeitos por causas dadas e conhecidas. Como as presentes reflexões efetivamente não oferecem categorias prontas nem relações causais 
pré-definidas, tais démarches (eventualmente interessantes para outros objetos) não encontram aqui aplicabilidade.

O propósito de uma heurística é sobretudo o de fornecer modos de olhar um objeto a ser investigado, de fazer aproximações tentativas que, em vez de inscrever o objeto em um conceito que dedutivamente o explica, procuram inquiri-lo até obter descobertas sobre sua especificidade, suas características próprias. A palavra heurística significa justamente a arte da descoberta.

As características próprias do objeto, descritivamente obtidas, devem por sua vez se relacionar em um quadro de percepções mais abrangentes, no qual a singularidade do objeto forneça elementos para uma percepção ampliada do fenômeno geral de nosso interesse, que é a comunicação.

O processo da heurística se faz em dois níveis. Primeiro, estimulando determinadas perguntas, para esclarecer aspectos do objeto que permitam evidenciar características comunicacionais deste. Depois, e na medida em que perguntas desse tipo (não necessariamente as mesmas, mas de mesma ordem) sejam feitas a outros e outros objetos, ainda que diferenciados entre si, será possível, então, cotejar esses objetos, malgrado sua variedade, pelas respostas que oferecem. Obtém-se, no processo, uma percepção mais abrangente a respeito das características observadas.

Dado esse critério comum, de responder a uma mesma ordem de perguntas, a própria diversidade deixa de ser dispersão, passando a constituir um corpo relacionado de características, de aspectos, de variações, que informam sobre o fenômeno maior do qual os objetos são realizações e exercícios singulares.

Assim, episódios, dispositivos interacionais, circuitos, tentativas, códigos, inferências consideradas nos processos comunicacionais em estudo não são categorias, entre as quais houvesse 
qualquer interesse em distribuir elementos observados em nosso objeto de estudo. Podemos - muito diversamente - decidir se é estimulador de descobertas (ou não) tratar nosso objeto específico segundo tais perspectivas.

Assumindo que o seja, como exercer essa heurística?

Para encaminhar essa questão, desenvolvemos dois passos metodológicos. $\mathrm{O}$ primeiro corresponde a reunir as proposições feitas, agora em formulação aforística, para referência sintética. As duas séries de proposições, sobre dispositivos interacionais e sobre circuitos - a segunda, articulada à primeira; ambas se caracterizando como diferentes modos de interação - consolidam nossas principais premissas.

No segundo passo, desenvolvemos perguntas relacionadas às premissas. São questões tentativas - outras podem ser elaboradas. São também abrangentes - podem ser consideradas questões de horizonte a partir das quais perguntas mais especificamente voltadas para os observáveis em investigação serão feitas segundo as lógicas do caso em estudo.

Esses dois passos são expostos sucessivamente, adiante - nos itens 2 e 3 , as premissas; nos itens 5 e 6 as perguntas.

Não se trata, então, de uma listagem para aplicação formal, como se de sua resposta decorresse, meio automaticamente, o sistema de relações interacionais do processo comunicacional em pesquisa. Para cada pesquisa específica, para o caso singular, algumas podem ser pertinentes, outras não. Algumas talvez sejam diretamente aplicáveis, outras precisarão de redirecionamento solicitado pelo próprio objeto. As questões indicadas se colocam, então, apenas como estímulo a uma postura interrogativa sobre o objeto, na lógica das reflexões heurísticas aqui trabalhadas. 


\section{Premissas básicas da heurística: Dispositivos Interacionais}

\subsection{A Comunicação}

a. A comunicação se realiza nos episódios de interação em que os seres humanos se engajam cotidianamente.

b. A comunicação é um trabalho de compartilhamento entre diferenças, como modo de enfrentar, resolver ou fazer agir criativamente essas diferenças.

c. A comunicação é sempre uma ação entre participantes em contexto. $\mathrm{O}$ modo pelo qual a sociedade produz seus variados processos interacionais viabiliza o funcionamento de ambientes de articulação, dando espaço (apenas parcialmente normatizado) para os participantes sociais exercerem suas táticas e estratégias.

d. A comunicação não é algo que ocorre ou não ocorre, como alternativas mutuamente excludentes. Frequentemente canhestra, sempre imperfeita, se exerce em variados graus de qualidade, sucesso e valor.

e. A comunicação é tentativa - se realiza probabilisticamente, com graus variados de "sucesso". Essa tentativa se refere mais propriamente ao que a sociedade tenta viabilizar pelos processos disponíveis do que apenas ao esforço dos participantes para atingir seus objetivos diferenciados.

f. A comunicação é transformadora, acionando elementos já compartilhados, em um determinado momento, como base para produção de novos compartilhamentos, fazendo incidir esse processo, inferencial, sobre o já compartilhado, produzindo mudanças de sentido, e tensionando o próprio dispositivo em uso. 


\subsection{Episódios \& Dispositivos}

g. Em cada situação, a sociedade gera tentativamente, em modo prático - por seus episódios interacionais - processos inferenciais para seu funcionamento. Tais práticas acabam se organizando em dispositivos variados, que por sua vez "modelam" o funcionamento comunicacional das interações que acionam os dispositivos.

h. O episódio comunicacional, que é a comunicação concreta, se desenvolve, assim, no âmbito de "dispositivos interacionais", produzidos nas circunstâncias históricas e acionados nos contextos específicos dos participantes.

i. Correlatamente, o episódio interacional acionador de tais dispositivos lhes dá forma, sentido, substância e direcionamento. Na sucessão de episódios, os dispositivos interacionais são desenvolvidos, mantidos etransformados, por suas táticas e inferências para ampliar a probabilidade de obtenção de resultados.

j. Os objetivos dos participantes se articulam aos objetivos do processo e os tensionam.

k. Na ausência ou insuficiência social de dispositivos para os objetivos singulares de um episódio, entram em ação processos experimentais que, na medida de seu interesse social mais amplo, são potenciais geradores de novos dispositivos.

\subsection{Códigos \& Inferências}

1. Os componentes básicos de episódios e dispositivos interacionais podem ser observados por suas características de "código" - elementos compartilhados que dão suporte 
à organização dos dispositivos e à interação real; e pela presença ou exigência de trabalho inferencial, como elemento interacional ativo.

m. A distinção entre códigos e inferências não caracteriza um objeto fraturado, dual: através da inferência, o ainda não compartilhado se produz em compartilhamento; o código, sempre incompleto, se desenvolve pela inferência; que, por sua vez, na reiteração tentativa, acaba por se organizar como código.

n. O processo comunicacional de transformação se manifesta particularmente nesse trânsito contínuo entre aqueles dois aspectos da comunicação: os códigos se exercem por acionamento inferencial; as inferências, na medida de sua pertinência, geram códigos.

o. Por isso mesmo, no trabalho de pesquisa, o que interessa não é classificar os elementos nas duas categorias; mas sim perceber como se relacionam, para qual trabalho interacional são acionados, que sistema de relações compõem, quais as suas dinâmicas na interação.

\subsection{Contextos}

p. Os dispositivos interacionais são modulados pelos contextos e processos instituídos ou experimentais específicos em cujo ambiente ou referência se desenvolvem.

q. Além disso, reflexivamente, os processos desenvolvidos nos episódios interacionais passam a incidir sobre seus contextos, modificando-os através de seus resultados e do fenômeno da circulação. 


\section{Premissas básicas da heurística: Circuitos de Comunicação}

\subsection{Circulação \& Circuitos}

a. Os resultados de um episódio interacional se oferecem como matéria possível para outras interações, tanto materializados em produtos de sentido, como na forma de memória e referência a falas, gestos e decisões.

b. Os elementos de saída de um episódio (decisões, encaminhamentos, ideias, sentimentos expressos, objetivos, etc.) se mostram em circulação, alimentando sucessivos episódios interacionais. Os episódios que acolhem aqueles elementos os relacionam, por sua vez, a seus próprios processos e metas, inscrevendo-os em outros sistemas de relações e viabilizando novas inferências.

c. Constatamos, nesse processo, um fluxo comunicacional contínuo e adiante que dinamiza o que se passa entre diferentes dispositivos interacionais. Após a apropriação de sentidos daquilo que recebem ou captam, os participantes de um episódio podem pôr em circulação no espaço social sua resposta. Essa resposta, à diferença das interações conversacionais, não se manifesta como ida-e-volta entre participantes. $\mathrm{O}$ retorno relevante nesse âmbito é aquele, difuso, do circuito ampliado e não a volta imediata ao ponto de partida.

d. A comunicação social pode ser apreendida, em parte, como um fluxo incessante de ideias, informações, injunções e expectativas que circulam em formas e reconfigurações sucessivas. As múltiplas ideias, proposições, imagens, posições polêmicas e tendências expressas se reforçam, se contrapõem, desaparecem ou retornam. Nesse processo, 
a circulação extrapola o intervalo, que era antes assumido como enfoque principal, entre "produção" e "recepção".

e. Assim como os dispositivos e episódios interacionais, o processo de circulação entre eles é também tentativo. Mas os percursos e vínculos entre os sucessivos núcleos de interação não se constituem $a d-h o c$, a cada processo de encaminhamento. A sociedade elabora - através das tentativas comunicacionais de criação, de ajuste e de aperfeiçoamento - processos mais ou menos reiterados de conexão e de tensionamento entre diferentes tipos de episódios, desenvolvendo assim lógicas articuladoras entre os dispositivos interacionais acionadores da circulação. Tais conexões acabam por constituir um circuito habitual que passa a direcionar o fluxo comunicacional - envolvendo manutenção, modificação, contraposição e acréscimo de ações, encaminhamentos e objetivos.

f. O circuito, uma vez constituído entre diferentes dispositivos interacionais, implica trânsito de objetivos, resultados e transformações - que se apresentam como informação (elementos compartilhados ou imediatamente compartilháveis); e como questões para reinterpretações e novas ações comunicacionais, nos episódios subsequentes, viabilizando frequentes redirecionamentos.

g. Um mesmo dispositivo interacional pode estar inscrito em diferentes circuitos.

\subsection{Escuta e retroação de sentido}

h. Na medida em que a comunicação se amplia e se acelera pela midiatização social, aciona crescentemente uma escuta e uma produção centrada no polo receptor. 
Podemos discernir aí uma retroação de sentidos, que vai da recepção à produção, não como "retorno de resposta", mas como previsão e antecipação da leitura que será feita.

A tendência à serialidade que se evidencia na sociedade em midiatização favorece que as expectativas sobre os passos subsequentes de um circuito sejam aperfeiçoadas e ativadas para as novas "edições" dos passos anteriores. Na reiteração serial dos passos de um circuito, pode-se efetivamente observar reações dadas e fazer ajustes tentativos: a comunicação, nesse movimento, remonta de jusante a montante. Nessa incidência retroativa, passamos a acionar interações a partir das respostas que pretendemos, esperamos ou receamos.

\subsection{Pontos nodais da circulação}

i. Os dispositivos interacionais e seus episódios são os pontos nodais da circulação. $\mathrm{O}$ "produto" corresponde apenas a uma parte dos elementos de saída e de entrada que relacionam dispositivos interacionais no circuito. Em cada ponto nodal ou "estação" identificável, são estimuladas ações interacionais, adjunção de códigos, acionamento de inferências e, portanto, geração de outros sistemas de relações entre os componentes aí articulados.

\subsection{0 produto no circuito}

j. Como o circuito comunicacional extrapola as relações entre produção e recepção, o produto mediático não deve ser visto como ponto de partida no fluxo. $O$ produto se elabora, já, como consequência de processos, expectativas 
e ações que resultam em sua composição como "um objeto para circular”. O produto não institui sua própria circulação: se faz para um circuito no qual se viabiliza e ao qual alimenta. É preciso então substituir a ênfase no "produto que circula” por uma percepção de circuito mais ampla, procurando enfocar a observação em nível mais abstrato.

k. O produto, entretanto, é um momento auspicioso da circulação - porque, consolidado em sua forma que permanece (e que se multiplica, na sociedade em midiatização), pode continuar circulando e repercutindo em outros espaços. Torna-se um especial objeto de observação e pesquisa para inferências sobre os processos mais gerais em que se inscreve. Ocupa um lugar especial por sua materialidade e consequente facilidade de captura para observação e inferências. É um "momento" particularmente feliz, por sua materialização, de um circuito que começa antes e continua depois.

\subsection{As lógicas do circuito}

1. Nos circuitos da sociedade em midiatização não prevalecem as lógicas deste ou daquele meio nem de determinados tipos de meios. Não cabe contrapor os meios digitais aos meios de massa como se fossem caracterizadores de mundos diferentes. Cada circuito compõe diferentes articulações entre o massivo e o digital, engastando ainda, aí, o presencial e a escrita.

Não cabe, também, descurar os momentos em que os dispositivos criadores e repassadores dos processos em circulação sejam de ordem conversacional (presencial ou a distância), organizados 
ou espontâneos - não mais acantonados em um espaço mudo de recepção. Diversamente, tais dispositivos comunicaconais interpolam sua fala no fluxo aparentemente mais vistoso e acelerado da mídia.

\subsection{Circuitos versus Campos Sociais}

$\mathrm{m}$. Os circuitos não se desenvolvem no vazio. Há uma sociedade pré-mediática instalada, por suas instituições e estruturas historicamente elaboradas, que ativam, como hábito, seus processos comunicacionais constitutivos. Tais estruturas podem ser percebidas e estudadas enquanto campos sociais (Pierre Bourdieu; Adriano Rodrigues).

Dentre esses campos, o "campo dos media" corresponde a um delineamento institucional/profissional evidente Este campo não é, porém, "o responsável" pela midiatização da sociedade, senão na medida em que todos os campos sociais igualmente o são, cada um com suas incidências específicas.

Cada campo social participa de circuitos múltiplos. Com a midiatização crescente, os campos sociais, que antes podiam interagir com outros campos segundo processos marcados por suas próprias "lógicas de campo" e por negociações mais ou menos específicas de fronteiras, são crescentemente atravessados por circuitos diversos.

n. A intensidade atual da circulação, o surgimento de articulações e de fricções leva a uma ocorrência de processos experimentais pela sociedade: a cultura da midiatização em implantação se faz por experimentação, estimulando fortemente a invenção social. 
o. Onde anteriormente os processos principais da comunicação podiam ser conduzidos pelas lógicas de campos específicos e por negociação em zonas de fronteira entre campos, hoje o trabalho de articulação com o todo social exige o desenvolvimento de táticas e usos para os circuitos disponíveis, negociando com seus objetivos.

p. Paralelamente, os campos sociais agem sobre os circuitos, inventam, redirecionam ou participam da estabilização de procedimentos da midiatização, experimentam práticas mediáticas, se inscrevem, para seus objetivos interacionais próprios, em circuitos midiatizados, dão sentidos específicos ao que recebem, transformam e repõem em circulação - por isso mesmo, modificando a si próprios. Por ação de determinados agentes internos aos campos sociais, assim como de agentes externos, mudanças decorrentes de processos em experimentação modificam os sentidos e os modos de ação dos campos sociais; outros campos se desenvolvem; e, sobretudo, os modos de interação entre os campos sociais, e entre cada um destes e a sociedade ao largo, se modificam.

\section{0 gesto da heurística}

Como entender - e sobretudo, como acionar para a pesquisa - essas proposições? Podemos afirmar que são inferências sobre determinados aspectos do fenômeno comunicacional. Foram lentamente refletidas a partir de observações empíricas de pesquisas que venho desenvolvendo nos últimos doze a quinze anos. Estão sendo testadas sobre diversos outros materiais e situações - o suficiente para que tenhamos, hoje, uma percepção de sua razoável abrangência para o estudo de casos em perspectiva propriamente 
comunicacional - sempre que possamos assumir a importância, em um estudo de caso, de perceber suas lógicas interacionais.

São, entretanto, afirmações genéricas: não respondem, de modo algum, sobre a especificidade do caso a observar, nem explicam sua inserção em uma categoria geral qualquer. Afirmar que "a comunicação é um trabalho de compartilhamento entre diferenças"; ou que "a comunicação é tentativa" não consolida o caso.

Posso, porém, descrever o caso segundo tais perspectivas. Se a comunicação é tentativa (uma premissa heurística envolve um elemento condicional, uma possibilidade a ser posta como estímulo), posso descrever o caso segundo aquilo que os participantes estão ali tentando; e sobretudo, observar o que no próprio processo se apresenta como tentativo.

O que obtenho, com essa descrição, não é uma resposta padrão que reconduza o caso a uma categoria anteriormente dada - mas sim uma percepção de suas lógicas específicas quanto a esse ângulo. Não se pretende, é claro, que cada lógica interacional seja sui-generis, que seja singular - a própria ideia de dispositivos socialmente elaborados e disponíveis se põe contra essa alternativa. Mas só após a descrição segundo o ângulo assumido terei a especificidade do caso. Essa especificidade (diferente da ideia de singularidade) é explicitada como modelo próprio, que esclarece o sistema de relações e as lógicas práticas ocorrentes naquele caso. Só após a descrição poderei obter o quadro em que o objeto da pesquisa se inscreve de modo não banalizado - como o seria se fizéssemos sua inserção prévia dentro de um conjunto de categorias.

É preciso sublinhar que a questão iniciada pela condicional "se", conforme estabelecemos no presente argumento ("se a comunicação é tentativa, então...”) não se resolve como raciocínio dedutivo. $O$ passo seguinte não é uma conclusão lógica e necessária que relacione a premissa posta (como se fosse uma premissa maior) com uma premissa 
menor (referente ao caso) para dar rigor de verdade ao resultado. Dada a premissa heurística, de ordem abrangente, o passo seguinte é tirar daí uma pergunta que pede a descrição: se a comunicação é tentativa, o que - aqui, nesse caso em estudo - está sendo tentado?

A heurística pede, justamente, a busca de indícios, através de uma descrição segundo o ângulo da pergunta feita; e a elaboração, a partir daí, de inferências abdutivas - assumindo, assim, o paradigma indiciário de investigação (Ginzburg, 1989; Braga, 2008). A inferência abdutiva é que será, então, nossa resposta. Hipotética, mas crescentemente testada e completada pela sucessão de perguntas e de descrições.

A cada uma das proposições encaminhadas nos itens anteriores, podemos, portanto, fazer perguntas correspondentes - de ordem geral e tentativa - por sua vez estimuladoras de descrições direcionadas para a descoberta a respeito do caso específico que se esteja esquadrinhando. As referências entre parênteses remetem às premissas correspondentes.

\section{Questões decorrentes de premissas sobre Dispositivos Interacionais}

\subsection{A Comunicação}

Ver se é possível (e se é produtivo) observar e descrever o objeto da pesquisa como um caso de episódio interacional (2.1.a).

Que diferenças parecem ser relevantes e podem ser levantadas, descritas, no observável? Que modos de compartilhamentos os participantes tentam? (2.1.b).

Lembrar que "compartilhamento" é diferente de consenso ou acordo. O compartilhamento pode se conflituoso. (2.1.b). 
Que ações? Como posso perceber suas lógicas? O que está "em questão"? (2.1.c).

Observar graus qualitativos do processo. (2.1.d).

Quais seriam os objetivos sociais do processo (enquanto distintos dos objetivos deste ou daquele participante)? O que a sociedade tenta realizar através do dispositivo interacional (já disponivel ou em construção no caso examinado)? (2.1.e).

Como as ações dos participantes se relacionam com os elementos já compartilhados entre eles? Ocorrem transformações (nas ações dos participantes; nos dispositivos acionados; no grau de compartilhamento; nos processos de compartilhamento; na experiência compartilhada)? Como parecem ocorrer essas transformações? (2.1.f).

\subsection{Episódios \& Dispositivos}

Que dispositivos "habituais" (culturalmente difundidos) podem ser percebidos em ação, acionados por um ou mais participantes? Parece ocorrer tendência de geração experimental de dispositivos? (intencional ou não) (2.2.g-2.2.h).

Em quê o episódio parece especificar e/ou tensionar dispositivos mais habituais? (2.2.i).

Como esses objetivos se articulam? Como se tensionam mutuamente? (2.2.j).

Há processos experimentais em curso? (no episódio específico em estudo; e/ou na classe de episódios na qual o que observamos se inscreve) (2.2.k). 


\subsection{Códigos \& Inferências}

É possível perceber incidências mútuas entre os diferentes processos - reiterações, tensionamentos, mixagens? Que inferências são requeridas para o uso dos códigos? Ações inferidas tendem a reiteração? $(2.3 .1-2.3 . m-2.3 . n-2.3 .0)$.

\subsection{Contextos}

Que contextos parecem relevantes? Como os ambientes observados incidem sobre o episódio interacional em estudo? (2.4.p - 2.4.q).

$\mathrm{Na}$ ocorrência de processos experimentais, como o que é experimental relaciona episódio e contexto? (2.4.p - 2.4.q).

Como os processos do episódio em estudo parecem incidir sobre o que o pesquisador assumiu como contexto relevante? (2.4.p $-2.4 . q)$.

\section{Questões decorrentes de premissas sobre Circuitos de Comunicação}

\subsection{Circulação \& Circuitos}

Verificar se é mais produtivo circunscrever a observação aos processos interacionais do episódio; ou se é mais interessante estudar sobretudo as conexões e tensionamentos entre dispositivos interacionais, com base no circuito que se estabelece entre eles. (3.1.a).

Quais são os elementos de saída? Como são apropriados e acionados por interações sucessivas? Que reinserções essa acionamento 
faz, para inscrever os elementos acolhidos em seu sistema de relações interacionais específico? (3.1.b).

Que fluxo se constitui no processo de acolhimento de elementos de outros dispositivos interacionais; de apropriação e acionamento; de geração de "respostas", como novos elementos de saída? (3.1.c).

Que seleções, complementações, transformações, contraposições e redirecionamentos são exercidos nos produtos, nas proposições, informações, etc. que são repassados da sequência do circuito? (3.1.d).

Que tentativas sociais de circulação o circuito caracteriza? Como essas tentativas se compõem no conjunto de dispositivos interacionais? Que sistema de relações se pode perceber nessa composição de conjunto - em termos de reforço, tensionamento, agonística, contraposição, desvio, questionamentos e outras ações? Que tentativas processuais caracterizam o circuito? (3.1.e).

Que aportes informacionais os elementos apropriados/acionados trazem para o episódio que os acolhe? Que questões e desafios oferecem? (3.1.f).

Alguns dos dispositivos interacionais do circuito em observação apresentam a característica de comutadores entre diferentes circuitos? (3.1.g).

\subsection{Escuta e retroação de sentido}

Há ações explícitas e relevantes de escuta de um dispositivo sobre outro? Como se realiza? Que previsões e antecipações se fazem 
em determinado dispositivo interacional quanto às apropriações e acionamentos a serem feitos nos dispositivos subsequentes? Há processos de serialização que viabilizem ajustes de saída com base no acolhimento já experimentado? (3.2.h).

\subsection{Pontos nodais da circulação}

Como a ação dos pontos nodais ou entre pontos nodais se evidencia como caracterizadora do produto (ou qualquer outra forma de processo em circulação)? (3.3.i).

\subsection{0 produto no circuito}

Correlatamente à questão anterior, como o produto (e processos correlatos em circulação) se faz, em vista do circuito para o qual é previsto? Em consequência de quais interações a montante; e na expectativa de quais processos a jusante? (3.4.j).

Como o produto realiza a processualidade interacional que o antecede, em dispositivos anteriores? Como o produto consolida os processos que o elaboram, no dispositivo interacional de sua criação? Como o produto expressa tais interações - e portanto viabiliza inferências sobre estas? (3.4.k).

\subsection{As lógicas do circuito}

Diante de um circuito observado, que lógicas articulam, com especificidade, os diferentes pontos nodais (dispositivos), os diferentes meios, os momentos midiáticos e os momentos de ordem conversacional? Como o sistema de relações entre os pontos nodais, que são 
os dispositivos interacionais, conjugam, na sua existência singular, tais diferenças e especificidades? (3.5.l).

\subsection{Circuitos versus Campos Sociais}

Que campos sociais são atravessados pelo circuito em observação? Como determinados pontos nodais se relacionam com tais campos? Como os campos sociais negociam processos com os circuitos que os atravessam, e sobre os quais buscam ter incidência? (3.6.m).

Que processos de experimentação e de invenção social podemos discernir no circuito em estudo? Como as lógicas dos campos sociais interessados sofrem tais experimentações ou as exercem? (3.6.n).

Que sentidos específicos, que apropriações, os campos sociais em pauta exercem por sua inserção no circuito em observação; e como se reformulam nesse processo mesmo? Como a complexidade do campo social e suas tensões internas são levadas a esse espaço de circuitos externos ao campo? Por quais tipos de agentes internos? Que agentes externos ganham espaço de ação sobre processos antes circunscritos a decisões esotéricas dos campos? (3.6.o).

Os nove capítulos que se seguem expõem casos empíricos trabalhados por seus autores individuais a partir do Seminário de outubro de 2012, referido na Apresentação. Representam, concomitantemente, uma mesma preocupação de captar as lógicas e características comunicacionais específicas de seus objetos, segundo a apropriação que seus autores fazem de nosso ângulo de estudo. 
É relevante assinalar que, naquele Seminário, nosso ponto de partida reflexivo eram três artigos apresentados a debate: "Nem rara, nem ausente, tentativa"; "Dispositivos Interacionais"; e "Circuitos versus Campos Sociais" (José Luiz Braga, respectivamente 2010c; 2011 b; 2012b). Estes artigos foram elaborações iniciais da perspectiva aqui apresentada. $O$ texto até aqui apresentado não se confunde com estes artigos - embora os tenha tomado como ponto de partida. As reflexões expostas nesses três capítulos iniciais derivam, primeiro, dos próprios debates do Seminário de 2012; em seguida, de atividades de pesquisa sobre os temas, sempre em desenvolvimento nesse período; e finalmente, dos nove capítulos empíricos que se seguem - em relação estreita com nossas reinterpretações destes.

Após cada capítulo, fazemos um comentário curto, a que denominamos "suíte", explicitando aspectos comunicacionais relacionados às perspectivas conceituais aqui apresentadas. Outras reflexões, transversais, são feitas, após, em capítulo de conclusão, completando as articulações desenvolvidas entre a parte reflexiva geral do livro e os elementos específicos de observação empírica. 


\section{Parte II \\ Estudos Empíricos}




\title{
4. Assange, Snowden, Greenwald
}

\author{
Leon Rabelo
}

\section{Introdução}

De que forma a acessibilidade da esfera pública contemporânea está se reconfigurando mediante as dinâmicas de apropriação e deslocamento de grupos constituídos nas novas culturas de rede? Que circuitos e nódulos estão emergindo, particularmente quando se analisam as 'problemáticas de atravessamento' de campos historicamente consolidados e basilares da esfera pública moderna, tais como o jornalismo e os estados nacionais democráticos?

Sabe-se que a esfera pública sempre foi um conceito em transformação. Há muito tempo não se fala mais de uma esfera pública, mas de inúmeras esferas, que vão se delineando a partir de suas interações específicas. (Crossley \& Roberts, 2004) Ou seja, as características ideais de abertura e acessibilidade discursiva dos espaços públicos modernos, segundo as quais todos seus integrantes teriam as mesmas possibilidades de participação, sempre foram tensionadas por condições e circunstâncias de funcionamento efetivas. Nestas, operam as mais diversas estratégias, recursos, interesses e correlações de força. Além disso, as esferas públicas sempre foram plasmadas por configurações relativas às suas estruturas materiais, técnicas e institucionais. Todos esses fatores, que sempre serão controversos e cambiantes historicamente, compõem em seu conjunto as diferentes 'arquiteturas de acesso' à publicidade. As últimas 
duas décadas de nosso tempo estão vivendo fortes movimentos de mudança quanto a esse tipo de configuração, sendo hoje consenso que as tecnologias de rede emergentes, com sua facilidade de produção, publicação e compartilhamento, provocam importantes curvaturas na maneira de como diferentes temas e discussões chegam à atenção pública e nela circulam.

Dentre inúmeros exemplos, serão aqui descritos e discutidos três casos, escolhidos por serem indiciais de algumas dessas mudanças: o caso da organização Wikileaks, ${ }^{10}$ no relato de seu aparecimento, sucesso e crise; o caso mais recente das revelações feitas por Edward Snowden, o ex-funcionário da Agencia Nacional de Segurança dos Estados Unidos que, em junho de 2013, revelou ao mundo uma série de informações sigilosas, indicando que esse e outros órgãos de segurança governamentais estavam excedendo e fazendo mau uso de suas funções; ${ }^{11}$ e a fundação do website The Intercept por Gleen Greenwald.

Embora os três casos sejam distintos, separados por um intervalo de alguns poucos anos e tenham protagonistas diferentes, eles podem ser vistos como paralelos quanto aos seus movimentos de inflexão. Eles parecem indicar como grupos ou indivíduos estão encenando movimentos tentativos (Braga, 2010c) para alterarem os rumos do acesso social à informação publicamente relevante, especialmente sobre problemas e abusos das instituições de poder sobre os direitos individuais e as regras democráticas. Sobretudo, há novidades quanto à maneira pela qual esses grupos acessam, se apropriam e lançam suas questões de interesse na esfera pública, para ali serem acolhidos, rejeitados ou debatidos.

10 https://wikileaks.org/ consultado em 28/07/2014

11 http://en.wikipedia.org/wiki/Edward_Snowden 
Em termos práticos, os três casos se fundam na ação de vazamento de informações sensíveis e sigilosas, oriundas de diferentes instituições de poder. Informações cuja relevância para o olhar público, incluindo-se a pertinência de sua publicação, é sujeita a fortes controvérsias de interpretação, revelando problemáticas sobre diversas regras institucionais e seus protocolos. Fica evidente, no acompanhamento dos três casos, a importância justamente da quebra desses protocolos, a quebra de regras sistêmicas e suas consequências para as atores envolvidos, bem como seu desdobramentos enquanto debate público. Tem-se aí um problema comunicacional de enfrentamentos, atravessamentos, disputas e contradições entre diferentes grupos e agendas. Os três casos, portanto, podem ser visto como indiciais de circuitos que rearranjam os modos de acesso à atenção pública.

Como estratégia de abordagem, escolhemos apresentar o relato dos três casos, tais como eles surgiram na cena contemporânea, mostrando os modos e complicações pelas quais foram atraindo a atenção dos meios de comunicação, dos atores institucionais e diversos interpretadores. À medida que apresentarmos as três narrativas, serão mostradas aproximações ou diferenças entre elas, para que no final algumas conclusões possam ser tentadas. Faz-se a ressalva que os três casos ainda são processos em curso - especialmente o caso de Snowden - e que portanto ainda podem surgir movimentos imprevistos e contraditórios com o que será exposto aqui.

\section{Wikileaks}

É presumível que o Wikileaks já seja um projeto esgotado ou ao menos enfraquecido, após seu auge no começo da década de 2010. Sua importância, no entanto, faz com que ele ainda mereça ser debatido. Como foi amplamente noticiado desde seu surgimento 
em 2006, o Wikileaks é "uma organização transnacional de mídia sem fins lucrativos" ${ }^{12}$, cujo objetivo é publicar "postagens (posts) de fontes anônimas, documentos, fotos e informações confidenciais, vazadas de governos ou empresas, sobre assuntos sensíveis." ${ }^{13}$ Usando ferramentas de software de última geração, entre as quais "MediaWiki, Freenet, Tor e $P G P^{\prime 14}$, a proposta original do Wikileaks era proteger com anonimato a origem ou identidade de suas fontes, "permitindo um modo universal de revelar injustiças escondidas ou censuradas." ${ }^{15}$ Após o lançamento de seu site, o Wikileaks publicou uma série de vazamentos documentais que repercutiram na mídia internacional. Entre outros, foi divulgado, em abril de 2007, um vídeo mostrando o ataque de um helicóptero estadunidense a um grupo de pessoas em Bagdá, capital do Iraque, matando ao menos 12 delas, dentre as quais dois jornalistas da agência de notícias Reuters. ${ }^{16}$ Outra publicação que mereceu destaque foi o manual que instruía sobre o tratamento dos prisioneiros na prisão militar estadunidense de Guantanamo, em Cuba. ${ }^{17}$ Além disso, foram publicados relatórios militares secretos das forças de ocupação americanas no Afeganistão e Iraque, que atestam a morte de um grande número de civis. ${ }^{18}$ Finalmente, em novembro de 2010, no que talvez tenha sido a publicação de maior destaque, foi exposta uma grande quantidade de documentos diplomáticos secretos dos

12 www.wikileaks.org, consultado em 28/07/2014

13 http://pt.wikipedia.org/wiki/Wikileaks, consultado em 28/09/11

14 Idem.

15 Idem.

16 O vídeo, bem como um fórum de discussão a seu respeito, podem ser vistos em http://collateralmurder.com/ (consultado em 20/12/2011)

17 http://wikileaks.ch/gitmo/\# (consultado em 20/12/2011)

18 http://wikileaks.org/irq/ (consultado em 20/12/2011) 
Estados Unidos, em especial telegramas que discorriam sobre as relações e posicionamentos dos corpos diplomáticos americanos em relação aos seus aliados e amigos. ${ }^{19}$

Os resultados práticos da colaboração entre o Wikileaks e importantes publicações de notícias foram consideráveis. No caso dos telegramas diplomáticos, por nove dias consecutivos, as histórias extraídas dos documentos publicados pelo Wikileaks foram matéria de capa do jornal The New York Times, causando considerável repercussão midiática e institucional, além de ocupar, nas semanas e meses seguintes, importante lugar no agendamento noticioso internacional. ${ }^{20}$

Como bem observa Sergio Amadeu da Silveira, o Wikileaks não foi o primeiro fenômeno de publicação online de documentos ou materiais sigilosos, nem foi o primeiro caso em que se usaram ferramentas informatizadas para ocultar a identidade ou origem de suas fontes (Silveira, 2011). Mundo afora, há inúmeras postagens de vídeos e imagens na internet sobre assuntos sensíveis para instituições de poder e governos, especialmente sobre países ou governos totalitários, ou sobre ações politicamente controversas das democracias ocidentais. O Wikileaks, no entanto, foi um dos primeiros atores dentre essas novas práticas de publicação a conseguir credibilidade junto à opinião pública mundial, como instituição ou ator definido, atraindo assim atenção não só para essas novas práticas, quanto para si mesmo. Pode-se especular sobre os motivos disso.

Possivelmente, o Wikileaks teve sucesso em se apresentar como uma organização bem articulada e programática, e não apenas

19 http://wikileaks.org/cablegate.html (consultado em 20/12/2011)

20 Ver, por exemplo: http://uscpublicdiplomacy.org/index.php/newsroom/specialreports_detail/wikileaks_cablegate_media_monitor_reportl/_consultado em $07 / 03 / 2012$. 
como uma série de ações individuais. Ou simplesmente as condições estavam maduras, em termos de disseminação das culturas da internet e existência de grandes bancos de dados digitais, para possibilitar as ações que tornaram o Wikileaks conhecido no mundo inteiro. De qualquer maneira, o Wikileaks não deixa de se constituir num conjunto grande e complexo de problemáticas a ser analisado. Seu principal elemento característico - a publicação de vazamentos de documentos e conteúdos sigilosos - se apresenta em volumes e ritmos que antes do advento das novas tecnologias de informação e comunicação eram praticamente impensáveis.

Para comparar: um dos vazamentos mais famosos da recente história ocidental, que por suas características tem certa semelhança aos do Wikileaks, foi o caso chamado "Pentagon Papers", em 1971. ${ }^{21}$ Nele, cerca de sete mil páginas de documentos militares estadunidenses foram vazadas, durante a Guerra do Vietnã, e publicados pelo jornal The New York Times, causando uma alteração significativa de como a opinião pública internacional percebia aquela guerra no sudoeste asiático.

Já os vazamentos mais importantes do Wikileaks, tais como os da Guerra do Afganistão, do Iraque e os Relatórios Diplomáticos Estadunidenses, continham respectivamente $91.731^{22}, 391.832^{23} \mathrm{e}$ 251.287 documentos. ${ }^{24}$ Segundo o principal jornalista a cargo da publicação dos "Pentagon Papers", Daniel Ellsberg, em 1971 passaramse 22 meses entre o momento em que ele teve acesso aos documentos

\footnotetext{
21 http://en.wikipedia.org/wiki/Pentagon_Papers consultado em 10/11/2011

22 http://en.wikipedia.org/wiki/Afghan_War_Logs consultado em 10/11/2011

23 http://en.wikipedia.org/wiki/Iraq_War_Logs consultado em 10/11/2011

24 http://en.wikipedia.org/wiki/Cablegate consultado em 10/11/2011
} 
e sua publicação pelo The New York Times. ${ }^{25}$ Já nos casos do Wikileaks, em poucas horas, centenas de milhares de documentos e conteúdos publicados pelo site ficam acessíveis no mundo inteiro, para qualquer pessoa que tivesse acesso à internet. Obviamente, isso não implica em nenhuma diferença na valoração entre os dois processos, mas na observância de que as novas dinâmicas, tais como ocorrem dentro do ciberespaço, se diferenciam em função de fatores como o volume, rapidez e modalidades das publicações e que, em função disso, suas mediações e respostas precisam ser analisadas especificamente.

\section{Processamento em rede}

A funcionalidade mais importante do Wikileaks - a que propriamente engendra uma multidão de interações e interpretações ao seu redor - é a de permitir o livre processamento de seus bancos de dados a quem quiser, bastando acessá-las diretamente em seu site. Além de se poder fazer o download do conjunto dos documentos, é possível também acessar diferentes ferramentas online que possibilitam seu manuseio. Ou pode-se criar ferramentas novas, que contenham os vieses que bem se entender. Informações sensíveis de documentos, antes sigilosos, podem ser analisadas, sintetizadas e republicadas, por quem esteja interessado, seja em trabalhos individuais ou coletivos de investigação.

Essa 'funcionalidade social' quanto ao processamento de informações é estruturante do Wikileaks. É ela que engendra o ecossistema comunicacional ao seu redor. E ela se liga a dois aspectos correlatos, igualmente importantes: primeiramente, o volume massivo dos documentos publicados pelo site, contados em centenas

25 Documentário Page One - Inside The New York Times, http://www.imdb.com/ title/tt1787777/ consultado em 10/11/2011 
de milhares, faz com que sua análise, ao menos a curto prazo, não possa ser feito manualmente, seja por indivíduos ou organizações isoladas. Elas precisam ser processadas através de softwares especificamente criados, que permitem a totalização e visualização das informações contidas nos documentos. O surgimento do ecossistema em seu entorno é assim, ao menos em parte, uma demanda técnica, cujo resultado prático foi o surgimento dos inúmeros sites e ferramentas de análise dedicados a ela. ${ }^{26}$

$\mathrm{O}$ segundo aspecto estruturante, ligado ao necessário processamento coletivo dos dados publicado e constituinte de um campo de interações, é o surgimento de centenas de locais no ciberespaço que além de produzirem análises sobre os documentos vazados também hospedam cópias inteiras das próprias bases de dados do Wikileaks. Essas bases de dados copiadas são denominadas 'espelhos', sendo que em dezembro de 2010, apenas algumas semanas após a publicação final dos relatórios diplomáticos estadunidenses, já se podiam contar mais de 800 sites que desempenhavam essa função propagadora e apoiadora do Wikileaks. ${ }^{27}$

Uma observação, possível de ser feita a partir do exposto acima, é que o surgimento desse ecossistema em torno do Wikileaks não torna seu cerceamento mais difícil apenas do ponto de vista técnico -operacional. Como os sites espelho estão espalhados em inúmeros países, submetidos cada qual à suas jurisdições, seu cerceamento tampouco pode ser feito de maneira fácil e unificada dos pontos

26 Por exemplo: https://github.com/search?q=wikileaks\&type=Repositories $\& x=0 \& y=0$ consultado em $20 / 01 / 12$

27 http://tecnologia.terra.com.br/noticias/0,,OI4831926-EI12884,00-Quase+sites+pelo+mundo+ja+hospedam+copias+do+WikiLeaks.html consultado em 10/11/2011; e http://tecnologia.terra.com.br/noticias/0,,OI4841857-EI12884,00Google+Earth+cria+mapa+mundial+de+espelhos+do+WikiLeaks.html consultado em 04/12/2011 
de vista policial e legal. A partir das funcionalidades dos modos de publicação do Wikileaks, tem-se imbricações, portanto, ao mesmo tempo de ordem prática e técnica como jurídicas, políticas e mesmo diplomáticas.

É importante entender, também, que esse ecossistema de interações no entorno do Wikileaks não se constitui de processos harmônicos, previsíveis ou mesmo pacíficos. Seus desdobramentos são bastante complexos e, muitas vezes, contraditórios. Nestes, surge uma série de resistências e choques, dentro de uma teia de relações e acontecimentos frequentemente inéditos que fogem dos planejamentos ou acordos prévios entre seus atores, precisando ser analisados à medida que acontecem. Talvez, seja essa a fundamental dimensão dos movimentos comunicacionais do Wikileaks: a teia de conflitos e choques que suas ações provocam.

Por motivo de brevidade, será analisada resumidamente, uma dessas frentes, em que culturas institucionais ou praticas estabelecidas reagiram fortemente em relação às ações das novas formas de publicação do Wikileaks: a do jornalismo.

\section{Wikileaks e o Jornalismo: colaboração e disputa}

As maneiras usuais de produção noticiosa, ou parte significativa de suas práticas, rotinas e conceitos foram tensionadas e desafiadas pelo Wikileaks. Ao mesmo tempo, o Wikielaks não poderia existir sem o campo do jornalismo. Para que formulações e sínteses possam ser feitas a partir dos documentos vazados, para que essas informações possam ter um rápido acesso e circulação na esfera pública, os documentos devem ser trabalhados de acordo com os parâmetros clássicos de criação noticiosa, ou ao menos esta tem que ser tomada como referência prática. Essa continua sendo, afinal, a melhor maneira de, em cima de um banco de documentos 
ou dados, rapidamente se identificar tramas, atores, motivos e processos, reconstituir fatos e contextos relevantes para o alimento informacional da sociedade contemporânea.

Surge aí uma disputa: pela maneira que o Wikileaks opera, usando a internet como principal meio de publicação, a tarefa de criação noticiosa poderia, em tese, passar ao largo das instituições estabelecidas do jornalismo e suas atribuições tradicionais, bastando para isso que eles fossem publicados online. Percebe-se por vários testemunhos que houve - ao menos na época em que o Wikileaks eclodiu como fenômeno - uma considerável preocupação, por parte de importantes integrantes do jornalismo internacional, de como seriam afetados suas rotinas e a cultura em decorrência das novas dinâmicas de publicação na internet. ${ }^{28}$ Sendo o jornalismo uma forma estabelecida de mediação entre a realidade social e os públicos modernos, poder-se-ia apressadamente inferir que as novas dinâmicas do ciberespaço prescindiriam do que poderia ser chamado da 'intermediação institucional' do jornalismo. ${ }^{29}$

No entanto, ao menos no caso do Wikileaks, essa expectativa não se confirmou. $\mathrm{O}$ que surgiu foi um quadro bastante diferente $\mathrm{e}$ problematizável, no qual a afirmação de que o Wikileaks não precisa dos órgãos de notícia tradicionais deve ser fortemente relativizada, o que pode ser observado nos desdobramentos dos principais vazamentos do Wikileaks.

Numa entrevista em fins de 2010, o porta-voz do Wikileaks, Julian Assange, afirma que, no início de suas atividades, havia a expectativa, por parte da organização, de que os usuários individuais, não

28 Documentário Page One - Inside the New York Times, http://www.imdb.com/ title/tt1787777/ consultado em 20/02/2012.

29 Cf. entrevista com o editor do jornal espanhol "El País", Luis Cebrián, disponível em http://migre.me/5NOLt consultado em 26/09/11 
institucionais, espalhados pelo mundo, pudessem realizar, de forma espontânea e não coordenada, o trabalho inteiro de processamento dos documentos publicados por sua organização. ${ }^{30}$ No entanto, mesmo surgindo inúmeros 'sites espelho' e mapas interativos disponibilizados, houve um resultado muito abaixo do esperado em termos de resultados investigativos concretos que sintetizassem esse potencial em histórias esclarecedoras para o grande público. Nas palavras do próprio Assange: "em 2006, nós esperávamos que o público geral iria escrever artigos e análises, de forma colaborativa. Isso não se concretizou de fato." ${ }^{31}$ Não houve uma ampla onda de resultados 'noticiosos' em resposta às publicações do Wikileaks - $\mathrm{e}$ sobretudo, os resultados não foram rápidos.

Um possível motivo para esse resultado pouco expressivo é que, para que as tais 'histórias jornalísticas' fossem extraídas das massas de documentos publicados, são necessários dedicação e know-how propriamente jornalísticos. Ou seja, precisa-se de elementos conceituais, rotinas práticas e recursos humanos que se encontram nos órgãos de imprensa tradicional, e não nos públicos espalhados pelos ambientes virtuais.

Outro fator a ser considerado é que a internet não pode, de uma hora a outra, substituir todo um conjunto social de práticas, uma cultura e hábitos de como e onde as pessoas procuram se informar e inteirar sobre os acontecimentos. A credibilidade e a capilaridade que o campo jornalístico possui não podem ser transferidas automaticamente para uma organização como o Wikileaks.

30 Cf. documentário Wikirebels - The Documentary, disponível em http://onlinejournalismblog.com/2010/12/12/wikileaks-the-documentary/ consultado em 04/10/2011

31 Idem. 
A confirmação disso é que o Wikileaks, diante dos resultados iniciais abaixo do esperado, partiu para estabelecer diferentes parcerias com órgãos de notícia tradicionais, cujos profissionais, capacitação técnica e cultura investigativa lhes pudessem vir de auxílio. Assim, quando em fins de 2010 foram publicados os 'Relatórios Diplomáticos Estadunidenses', essa ação, desde seu início, foi planejada e realizada em parceria com importantes jornais, tais como o New York Times, o The Guardian, o Der Spiegel e o El País. Outro motivo para essa parceria, de ordem prática, foi uma necessidade ligada à deontologia jornalística: a da proteção das fontes.

Explica-se: em muitos casos, como por exemplo no dos relatórios diplomáticos estadunidenses, se todas as informações dos documentos vazados pelo Wikileaks fossem rigorosamente postas a claro, haveria o inevitável comprometimento de segurança de muitos dos informantes e delatores que tinham servido como fontes de informação para a feitura dos documentos. Tratava-se, muitas vezes, de interlocutores clandestinos que, se expostos, correriam grandes riscos de segurança pessoal. Sua proteção era uma exigência importante e se enquadra num dos preceitos mais básicos da prática jornalística: "a máxima exposição de assuntos de relevância pública, mas sem o comprometimento das identidades ou da segurança das fontes que as revelaram - caso seja essa sua vontade ou necessidade." (Christensen, 2012). Essa exigência, ademais, está de acordo com os princípios de origem do Wikileaks, que se apresentou como uma organização capaz de garantir - no processo de produção noticiosa - aquilo que até o presente o jornalismo, enquanto instituição, sempre tivera como uma de suas garantias. As matérias publicadas, em cima dos documentos vazados, requeriam esse tratamento prévio por parte dos jornalistas dos órgãos de notícia com quem o Wikileaks firmara parceria. 
Por tudo isso, vê-se que a afirmação 'o Wikileaks não precisa dos jornais' era equivocada. $\mathrm{O}$ Wikileaks teve grande necessidade dos órgãos de imprensa, restando o debate se essa relação é benéfica para as duas partes ou, por falta de termo melhor, 'parasitária' em prol do Wikileaks. Ora, pode-se também concluir que a função do Wikileaks dentro desses processos de parceria é bem diferente da função clássica de 'fonte de informações'. O Wikileaks entra na parceria com uma agenda própria. Na verdade - e eis uma constatação do presente trabalho - seus movimentos são de disputa quanto à correlação de poder dentro dos processos noticiosos, podendose observar uma inequívoca tentativa, por parte do Wikileaks, de interferência nos processos de pauta da agenda midiática. Há uma estratégia e tentativas de capturar, por parte da organização, a atenção pública. E tal ambição não vem tanto, ou apenas, do teor $\mathrm{e}$ relevância de seus documentos vazados, mas se mostra como clara tentativa de interferência e deslocamentos nos processos e rotinas usuais que, até o presente, regeram a criação cotidiana de notícias. Em última instância, é essa sua agenda, e é em relação a ela que os órgãos de notícia tradicionais necessitam oferecer respostas e reações. São esses, portanto, alguns dos elementos e movimentos propriamente comunicacionais da relação entre o Wikileaks com a mídia tradicional e as práticas do jornalismo.

\section{Crise do Wikileaks e surgimento de novos casos}

Ao encaminhar as conclusões do caso abordado, há que se lembrar que o Wikileaks é ainda uma história em andamento. Diversos fatores, no entanto, indicam que a organização chegou a uma crise bastante severa, talvez terminal. No final, ela não aguentou as diferentes formas de perseguição e contra-ataques desferidos por vários governos e instituições, tanto em relação à sua operação quanto ao 
financiamento. ${ }^{32}$ Sofreu também dissidências por conta do estilo excessivamente personalista de seu líder, Julian Assange ${ }^{33}$, e concorrência com o surgimento de organizações semelhantes. Um evento, em especial, parece ser sintomático das insuficiências do Wikileaks enquanto projeto. Naquilo que foi descrito como "uma cadeia de erros de diversos atores; uma espécie de falha colaborativa, ${ }^{34}$ houve a publicação inadvertida na internet dos documentos vazados sem nenhum tratamento que ocultasse as identidades das fontes e informantes. $\mathrm{O}$ princípio de proteção das fontes foi ferido e, em função disso, a organização foi severamente criticada pelos órgãos de imprensa com os quais ele tinha colaborado anteriormente, tais como os jornais The Guardian, The New York Times, Der Spiegel e El País. ${ }^{35}$

A relação mista de colaboração e disputa com o campo jornalístico, portanto, acabou se desequilibrando, com resultados desfavoráveis e mesmo inviabilizadores para o futuro do Wikileaks. Mas, para além do destino particular da organização, há que se observar o surgimento paralelo, ou decorrente, de várias outras organizações com objetivos similares. ${ }^{36} \mathrm{O}$ Wikileaks deve ser visto como um primeiro ensaio de uma tendência mais ampla e, portanto, como um indicador de mudança em como se darão as disputas por atenção por temas sensíveis na esfera pública. Isso fica evidente

32 http://www.independent.co.uk/news/world/politics/wikileaks-hit-by-new-online -onslaught-2151570.html consultado em 01/03/2012.

33 Conforme entrevista de David Leigh ao Globo News de 17/05/2011 http://migre. me/5Q0oH consultado em 04/10/2011.

34 http://apublica.org/2011/09/wikileaks-a-contagem-final-do-cablegate/ consultado em $14 / 09 / 2011$

35 http://www.dw-world.de/dw/article/0,,15362016,00.html consultado em $02 / 10 / 2011$

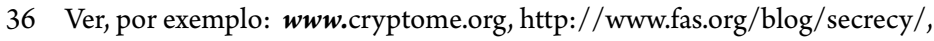


pela comparação com um caso semelhante e mais recente: o dos vazamentos de Edward Snowden. A comparação entre os dois casos parece indicar que os atores envolvidos em revelação de segredos institucionais estão criando uma cultura de aprendizado em relação a esse tipo de processo.

\section{0 Caso de Edward Snowden}

Em maio de 2013, um funcionário terceirizado da Agência Nacional de Segurança dos Estados Unidos, Edward Snowden, procurou o jornalista norte-americano Glenn Greenwald e a documentarista Laura Poitras, deslanchando um novo vazamento de documentos ultrassecretos, provenientes de instituições de segurança e controle do governo norte-americano. Segundo novamente a avaliação abalizadora do veterano jornalista Daniel Ellsberg, o mesmo do vazamento dos "Pentagon Pappers", em 1971, a importância desse vazamento superou qualquer vazamento anterior, inclusive os do Wikileaks. ${ }^{37}$

As comparações entre o Wikileaks e o caso Snowden são interessantes tanto por suas semelhanças quanto diferenças. Os dois processos tiveram como elemento desencadeante uma quebra de protocolo a partir de dentro de rígidos sistemas de segurança. No caso mais célebre do Wikielaks, o dos documentos diplomáticos, soube-se depois que o vazamento teve origem nas ações de um técnico de segurança das forças armadas estadunidenses, Chelsea Manning ${ }^{38}$. Quanto a Edward Snowden, ele também estava estrategicamente colocado, dentro do aparato de vigilância dos Estados

37 http://www.theguardian.com/commentisfree/2013/jun/10/edward-snowden-united-stasi-america consultado em 08/08/2014

38 http://en.wikipedia.org/wiki/Chelsea_Manning consultado em 19/07/2014 
Unidos. Ele fora gestor de sistemas para a Agência Central de Inteligência (CIA) e instrutor de contraespionagem da Agência de Inteligência da Defesa (DIA). Mais tarde, Snowden passou a trabalhar em postos-chave de empresas terceirizadas da Agência de Segurança Nacional (NSA).$^{39}$ Foi de lá que ele resolveu, depois de longa preparação, vir a público com o que sabia sobre os métodos, a seu ver pouco republicanos, do sistema de vigilância das agências estatais em que tinha trabalhado.

Nota-se que no caso Snowden, o acesso à atenção da esfera pública se deu por meios bastante mais convencionais do que o Wikileaks. Não se constituiu para tal um site ou plataforma tecnológica específica. Desta vez, a opinião pública tomou conhecimento do vazamento por meios das reportagens jornalísticas geradas em cima de entrevistas, a entrega pessoal de arquivos sensíveis, além da publicação de um livro. É neste último, escrito por Glenn Greenwald e lançado em maio de 2014 e intitulado "Sem Lugar para se Esconder: Edward Snowden, a NSA e a Espionagem do Governo Americano", que se pode acessar os relatos da parceria entre jornalistas e o consultor técnico em vigilância online, resolvido a expor em público os desmandos de importantes agências estatais de segurança.

De saída, nessa nova parceria entre fonte e jornalista, é digna de nota a complexidade já do primeiro contato. Para não deixar pegadas digitais e para não tornar sua localização passível de rastreio, Snowden tem que primeiro instruir o jornalista a uma série de medidas de precaução digital até que finalmente o encontro presencial possa ocorrer, fora do território e da jurisdição norte-americana. Foi num hotel em Hong Kong que Snowden grava uma série de entrevistas a Glenn Greenwald e Laura Poitras. Ele também entrega arquivos de material sensível e altamente confidencial

39 http://en.wikipedia.org/wiki/Edward_Snowden 
que, segundo ele, indicaria claramente que a Agência Nacional de Segurança dos Estados Unidos estaria extrapolando os limites razoáveis de atuação, passando a agir de forma daninha para os direitos de privacidade dos cidadãos e fora dos preceitos do estado de direito democrático.

No entanto, uma vez estabelecida essa parceria e arquitetada uma estratégia de como essas informações seriam reveladas, notase que ao contrário do caso Wikileaks, a principal fonte não quer se esconder. ${ }^{40}$ Mesmo se fazendo objeto de seriíssimas acusações criminais, por ter quebrado um sem número de protocolos e leis de segurança nacional, Edward Snowden não cogita o anonimato como estratégia, mas faz questão de vir a público e revelar sua identidade.

As punições do governo dos Estados Unidos não tardaram, tendo o Departamento de Justiça acusado Snowden de violar a Lei de Espionagem e roubo de propriedade do governo. Algumas semanas depois, seu passaporte foi revogado e Snowden acaba pedindo asilo político na Rússia, onde se encontra até o presente. Mesmo assim, a resolução de revelar sua identidade, sua atitude de se expor publicamente, faz com que no caso Snowden a fonte tenha um protagonismo inteiramente diferente da do caso Wikileaks. Aqui, ela é a principal baliza da credibilidade das informações e um articulador político de pleno direito. Vir a público e assumir politicamente a quebra das regras do protocolo é justamente o primeiro passo para se levantar o debate e propriamente iniciar uma discussão pública sobre a validade ou não de sua posição crítica.

Outro aspecto relevante do amadurecimento estratégico, no caso de Snowden, é o alto nível de organização do material entregue

40 http://www.theguardian.com/world/2013/jun/09/edward-snowden-nsa-whistleblower-surveillance consultado em 08/08/2014 
por ele aos jornalistas. Pelo relato de Greenwald, mais do que apenas um gesto repentino de assalto aos bancos de dados das agências de segurança, Snowden foi pacientemente coletando evidências das improbidades, organizando-as segundo suas áreas especificas para depois poder apresentá-las de forma clara e pedagógica aos jornalistas. Estes, mesmo com a boa experiência que tinham nesse tipo de assunto, ficaram abismados com a vastidão do sistema de espionagem montado pelas agências de segurança, ainda mais porque o sistema foi desenvolvido sem qualquer prestação de contas, transparência ou limite. Não apenas contra organizações pretensamente inimigas e de caráter terrorista, mas contra a própria população civil dos Estados Unidos e de países amigos e democráticos (Greenwald, 2014, p.97).

Entre os documentos vazados por Snowden, havia comprovantes de inúmeros programas e ações que possibilitam a coleta indiscriminada, por parte dos agentes de segurança, de qualquer tipo de rastro informacional deixado por um indivíduo ou organização, em qualquer modalidade de comunicação existente. A evolução tecnológica dessas ferramentas torna possível acessar ligações telefônicas, e-mails, registros comerciais, contábeis, buscas no Google, sites visitados e, claro, qualquer tipo de interação nas redes sociais, sejam elas privadas ou públicas, tudo isso em tempo real. (Greenwald,2014,p.162) E pior, essas ações podem ser feitas sem nenhum tipo de autorização judicial ou supervisão de outra autoridade. Nas palavras do próprio Snowden: "sentado à minha mesa, eu podia grampear qualquer pessoa, de você ou seu contador até um juiz federal ou mesmo o presidente; bastava ter um endereço de e-mail pessoal". (Greenwald, 2014, p.167).

Nota-se aqui uma interessante diferença entre os dois casos. O Wikileaks divulgou eventos, fatos e documentos. Já nas revelações de Snowden ficam mais evidentes, já de saída, os processos e metodologias da vigilância institucionalizada. Ou seja, há um valor 
agregado maior nas revelações de Snowden. Elas são mais instrutivas quanto às características do sistema de vigilância como um todo, não apenas sobre alguns de seus casos particulares.

As revelações de Snowden já mostram claramente, também, como as metodologias de vigilância eram usadas como estratégias políticas por parte do governo dos Estados Unidos e seus aliados próximos. Já ficam claros muitos de seus propósitos como, por exemplo, as ações de vigilância eram usadas para fazer espionagem corporativa e diplomática, mesmo em relação a governos, países e organizações democráticas sem nenhuma suspeita de envolvimento em atividades de risco para a segurança dos Estados Unidos. As informações extraídas eram simplesmente usadas para dar vantagens nas negociações que os Estados Unidos e seus aliados próximos tinham com esses países. (Greenwald, 2014, p.142-161).

Além dessas ações, já graves, as agências de segurança expostas por Snowden também usavam seu poder de intromissão para influenciar, de diferentes maneiras, o debate público. Seja agindo de maneira sub-reptícia em fóruns de discussão, seja criando factoides ou denegrindo a imagem pública de indivíduos e grupos que eles quisessem atingir, a sua presença velada se fazia sentir nos processos de criação e circulação de opinião na sociedade. (Greenwald, 2014, p.198-207). Pode-se argumentar que esse tipo de ação difamatória sempre existiu, por partes de governos e organizações. Mas a que tipo de situação se chega quando os agentes responsáveis por essas ações possuem praticamente qualquer tipo de informação disponível sobre a privacidade dos indivíduos ou as atividades de grupos que querem atingir, além de que essas informações foram obtidas sem os devidos processos legais ou qualquer responsabilização e auditoria? 
As revelações de Snowden tomaram a atenção pública com praticamente a mesma intensidade que o Wikileaks. Já nos primeiros dias, quando as matérias escritas por Greenwald foram divulgadas pelo The Guardian, os links foram retransmitidos centenas de milhares de vezes nas redes sociais. A entrevista de Snowden, onde ele se identifica e esclarece seus motivos teve três milhões de acessos no Youtube e outros tantos no site do The Guardian. (Greenwald, 2014, p.91). Como ocorrera no caso do Wikileaks, a esfera pública mundial mais uma vez voltou sua atenção às problemáticas de privacidade e vigilância, discutindo como as mediações tecnológicas contemporâneas permitem ora ocultamentos, ora desvelamento de improbidades institucionais ou do poder governamental.

Igual ao Wikileaks, a ação de Snowden foi motivo de violentas controvérsias sobre sua justeza ou legalidade. Alçado à condição de herói por respeitadas vozes do debate público norte-americano e internacional, ${ }^{41}$ para outros tantos ele era um dissidente ${ }^{42}$ ou mesmo um traidor. ${ }^{43}$ Enquanto um ex-diretor da CIA queria que Snowden fosse literalmente "enforcado" ${ }^{44}$, a Alta Comissária da Nações Unidas para Direitos Humanos, Navi Pillay, advogava que Snowden nem deveria ser julgado, pela relevância pública de suas revelações. Fica claro que, por sua radicalidade, uma ação como

41 http://www.newyorker.com/online/blogs/johncassidy/2013/06/why-edward-snowden-is-a-hero.html consultado em 12/08/2014

42 http://www.usnews.com/news/blogs/washington-whispers/2013/08/01/ edward-snowden-receives-asylum-in-russia-poll-shows-americans-sympatheticto-nsa-whistle-blower consultado em 12/08/2014

43 http://www.pbs.org/newshour/rundown/2014/01/gates-on-snowden.html consultado em 12/08/2014

44 http://www.foxnews.com/politics/2013/12/17/ex-cia-director-snowden-should -be-hanged-if-convicted-for-treason/ consultado em 12/08/2014 
a de Snowden choca-se com as normas convencionais e com as práticas usualmente aceitas dos campos político, diplomático e midiático, causando dissonâncias na maneira pelas quais estes se harmonizavam. Pode-se verdadeiramente falar aqui em dinâmicas de "atravessamento de campos" (Braga, 2012b), para as quais os diferentes mecanismos de resposta setoriais não tinham protocolos prontos e previstos.

Como resposta quase imediata das revelações, houve vários embaraços entre os Estados Unidos e países amigos, tais como o México, Brasil e a Alemanha. ${ }^{45}$ A revelação de grampeamentos até dos celulares dos mais altos representantes governamentais desses países causou mal-estar, chegando até a cancelar uma visita de Estado que a presidente Dilma Rousseff faria aos Estados Unidos. ${ }^{46}$ Cogita-se, ainda, que o caso Snowden tenha impulsionado, no Brasil, a retomada e tramitação do "Marco Civil da Internet", que distanciou o país das políticas de internet dos Estados Unidos e reacendeu o debate por uma governança global da rede mundial de computadores. ${ }^{47}$

No entanto, são ainda mais interessantes, para a presente análise, os desconfortos e choques que o caso começou a gerar entre o jornalista envolvido e sua relação com os órgãos de notícia para quem ele trabalhava. A esse respeito, Glenn Greenwald relata detalhadamente os cuidados, excessivos a seu ver, que o jornal para qual ele trabalhava, o The Guardian, tinha em relação a publicar ou não o material apresentado por Snowden. Invocando cláusulas de

45 http://www.theguardian.com/world/2013/oct/24/nsa-surveillance-world-leaders-calls consultado em 12/08/2014

$46 \mathrm{http}: / /$ politica.estadao.com.br/noticias/geral,dilma-cancela-viagem-aos -eua, 1075730 consultado em 12/08/2014

47 http://g1.globo.com/tecnologia/noticia/2014/04/netmundial-inicia-com-obrigado-snowden-e-defesa-da-internet-livre.html consultado em 12/08/2014 
segurança nacional e a possibilidade de sofrer retaliações, os editores relutavam em soltar as matérias de Greenwald. Mesmo sendo considerado uma publicação de linha editorial independente e arrojada, a insegurança do The Guardian chocou-se com os ideais do jornalista:

Tive a sensação de que estávamos deparando exatamente com o tipo de barreira institucional ao jornalismo agressivo que eu entrara no Guardian para evitar: preocupações jurídicas. Consultas a funcionários do governo. Hierarquias institucionais. Aversão ao risco. Atrasos. (Greenwald, 2014, p.75)

No campo jornalístico surge também o inevitável debate se Glenn Greenwald era, de fato, um jornalista. Embora ele já estivesse por anos atuando no campo de notícias, atuando como blogueiro e cobrindo sobretudo questões ligadas à política e a proteção dos direitos individuais na era da internet, sua formação superior fora em direito. Iniciou-se agora um debate, como no caso do Wikileaks, se o que ele estava fazendo era "jornalismo" ou "ativismo". Isso não apenas tinha implicações sobre a legitimidade de sua produção noticiosa, mas também sobre os tipos de proteção jurídica que Greenwald poderia invocar, caso fosse processado por suas ações. (Greenwald, 2014, p.225)

Novamente, percebe-se aqui o tensionamento de fronteiras entre os campos criados pelas dinâmicas de um evento de irrupção. Pretensamente, só se Greenwald fosse um jornalista 'de verdade', alojado dentro de uma instituição jornalística 'genuína', seguindo seus preceitos e deontologias, ele poderia fazer jus às suas proteções institucionais. Se não pertencesse a elas, segundo essa maneira de pensar, ele seria apenas um militante. Enfim, vê-se que as respostas 
sociais às ações ao caso Snowden patinam na indecisão de qual deveria ser, afinal, seu endereçamento correto.

\section{Fundação do The Intercept}

O corolário dessa problemática foi a saída de Greenwald do The Guardian ${ }^{48}$ e o estabelecimento, em fevereiro de 2014, do website The Intercept. ${ }^{49}$ Eis um movimento 'tentativo' importante, que pode ser visto como uma resposta aos impasses e dificuldades encontrados nos órgãos de notícia tradicionais. A finalidade do The Intercept, primeiramente é a de "fornecer uma plataforma de informação para os documentos da NSA apresentados pelo denunciante Edward Snowden". Essa cobertura, promete a equipe do The Intercept, será "abrangente, inovadora e multifacetada." Promete-se, ainda, que serão usadas todas as formas de mídia digital para a sua divulgação, que serão também publicados os documentos de fonte primária em que elas se baseiam e que especialistas externos com conhecimento da área serão convidados para contribuir com os relatórios criados. Além disso, será fornecida uma plataforma para comentários e interação dos leitores. ${ }^{50}$

A longo prazo, o objetivo do The Intercept é criar uma plataforma de produção noticiosa de pleno direito:

Nossa missão de longo prazo é produzir, sem medo, jornalismo crítico em uma ampla gama de questões. A independência editorial dos nossos jornalistas será garantida. Eles serão incentivados a perseguir suas paixões, cultivar uma voz única e publicar histórias sem levar em conta a quem

\footnotetext{
48 http://www.bbc.com/news/world-us-canada-24545344 consultado em 14/08/2014

49 https://firstlook.org/theintercept/ consultado em 14/08/2014

50 https://firstlook.org/theintercept/about/ consultado em 12/08/2014
} 
eles podem irritar ou atrapalhar. Acreditamos que o valor principal do jornalismo é o seu poder de impor transparência, e, assim gerar accountability, em relação aos mais poderosos órgãos governamentais e corporativos. Aos nossos jornalistas serão fornecidos todos os recursos e apoio necessários para fazerem isso. ${ }^{51}$

A equipe de uma quinzena de pessoas que compõe o The Intercept mostra trajetórias diversas. A grande maioria é do jornalismo, mas há também denominações como "autor independente", "analista de tecnologia", "especialista em sistemas operacionais de códigos abertos 'Linux/GNU”, “advogado”, “documentarista e artista". 52

A solução tentada - e que seja frisada a tentativa - não é a de criar uma ferramenta tecnológica de última geração, como foi no caso do Wikileaks. Trata-se antes de criar um espaço interacional que permita a agregação de experiências diversas. Através das mediações que as novas tecnologias permitem, pretende-se preencher algumas das lacunas criadas nos limites, ou impasses, entre as ações institucionais dos meios de comunicação, órgãos de segurança e os direitos da cidadania.

Nesse sentido, a tecnologia não é o mais importante. O The Intercept não é 'apenas' um blog ou website. Suas características fundamentais, as maneiras pelas quais ele pode engendrar interações e novos circuitos comunicacionais não vêm por conta de seu formato, ou pela tecnologia de web com o qual ele foi construído. A pretensão do The Intercept é ser, ao menos potencialmente, um dispositivo agregador da confiabilidade noticiosa e articulação de atenção pública.

51 Idem.

52 https://firstlook.org/theintercept/staff/ consultado em 13/08/2014 
Para ele, houve a migração de pessoas e funcionalidades de arranjos institucionais anteriores, que levaram consigo credibilidade, técnicas, acúmulos de conhecimentos e práticas. $\mathrm{O}$ The Intercept, enquanto encruzilhada de caminhos, enquanto dispositivo interacional, não estaria completo sem a presença de atores como o próprio Snowden, que ali pode aportar toda sua bagagem de conhecimento, sua trajetória dentro das agências de inteligência, com cujas práticas se viu constrangido e radicalmente insatisfeito, pelas consequências daninhas que, a seu ver, elas têm para a cidadania e a democracia.

De forma mediada, estará lá também a mistura de sucesso e fracasso que foi a experiência do Wikileaks. Quando foi a vez de Snowden se rebelar contra o sistema, ele buscou não o Wikileaks, mas um novo arranjo, que tivesse equacionado melhor a relação entre práticas jornalísticas e plataformas de internet. Não parece ser otimismo demais concluir, portanto, que da mesma forma que as agências e governos estão cada vez mais inteligentes no uso das novas tecnologias para vigiarem e controlarem a sociedade, os atores desta sociedade também estão aprendendo a ficar cada vez mais hábeis em resistir e enfrentá-los. 


\title{
Suíte $n^{0} 1$
}

\section{“Assange, Snowden, Greenwald", de Leon Rabelo}

\author{
José Luiz Braga
}

Os dispositivos e circuitos abordados por Leon Rabelo se organizam em um campo de forças muito tensionado pela política e por lógicas de segredo - de controle rigoroso da circulação e do acesso à informação. Os padrões institucionais de espionagem, muito estabelecidos, são enfrentados por uma lógica abrangente, de ordem social, que é a de resistir àqueles controles de circulação.

$\mathrm{O}$ estudo de Leon mostra duas tentativas originadas em pontos diversos da sociedade - se desdobrando, depois, em uma terceira processualidade que busca levar em conta dificuldades enfrentadas no âmbito das duas primeiras. Aparecem, no conjunto, movimentos claros de invenção social, através de correções e redirecionamentos sucessivos, com base nas experiências anteriores - aspecto relevante da comunicação. A invenção social é resultado de processos interacionais em que se aprende com a experiência e com as tentativas dos demais, fazendo reajustes e tentando outras coisas. Mesmo ocorrendo inicialmente em modo disperso, na medida de sua eficácia, passa a ser incorporada na cultura, na forma de modelos confiáveis que podem ser então acionados como dispositivos sociais. É o que parece começar a ocorrer, no âmbito apresentado pelo capítulo.

Quando acompanhamos nos jornais, sucessivamente, os dois casos, do Wikileaks e de Edward Snowden, a impressão predominante foi a de percebê-los como caracterizados centralmente por uma lógica de vazamento de informações assumidas como sigilosas. Embora a lógica e os processos de vazamento ocupem um papel 
importante nessa questão de circulação, Leon Rabelo aprofunda a observação, mostrando processos mais complexos.

Um primeiro aspecto assinalado pelo capítulo é que a diversidade de casos evidencia um processo social de experimentação - $\mathrm{e}$ não apenas tentativas isoladas entre si. Embora o estudo se concentre na análise dos casos observados, mostra também o "surgimento paralelo, ou decorrente, de várias outras organizações com objetivos similares" ${ }^{33}$. Sem entrarmos na história do esforço comunicacional pela transparência, contemporâneo do surgimento do jornalismo, na Europa do século XVII, sabemos que a complexidade crescente das democracias modernas faz o segredo ocupar espaço no exercício do poder, em contradição com uma valorização afirmada da esfera pública como espaço de deliberação.

Por sua vez, o jornalismo de grande mídia, vinculado a processos econômicos dominantes, adota um excessivo comedimento na defesa dos valores de esfera pública, sempre que as políticas do segredo acionam argumentos de segurança nacional ou referentes a interesses político-econômicos ditos "do país".

Somando-se a insuficiência da ação jornalística em defesa da transparência, os valores nunca abandonados de esfera pública (mesmo se pouco exercidos) e as possibilidades tecnológicas atuais de fazer circular informações, reúnem-se condições estimuladoras de diferentes iniciativas sociais em busca de uma comunicação social mais transparente. Os casos estudados se destacam não só pela repercussão que mereceram, como porque aí se desenvolvem ações comunicacionais relevantes e tentativas de elaboração de circuitos - pelas quais se amplia a compreensão dos processos em curso.

53 Salvo outra indicação expressa, todas as citações nas Suítes se referem ao capítulo imediatamente anterior, que estas comentam. 
No caso Wikileaks, a ênfase se coloca inicialmente no vazamento das informações. Trata-se sobretudo de acionar desvios, por meio de informadores contatados nos circuitos do segredo, de modo a disponibilizar maciçamente as informações obtidas. A expectativa de Assange (aliás mostrada na denominação ${ }^{54}$ ) seria a de que a simples disponibilização dos dados geraria uma ação social de interpretações colaborativas, que faria circular espontaneamente as notícias - selecionadas e analisadas em modo aberto.

Se se realizasse em abrangência adequada, essa ação difusa teria a potencialidade de concorrer com o sistema jornalístico instituído, para os temas desviados do segredo. Podemos inferir aí duas crenças, não plenamente realizadas como ação espontânea: no processo interpretativo difuso e na geração de circuitos mais ágeis através das redes sociais.

Leon mostra que as dificuldades do Wikileaks aparecem em diversos níveis: para a geração de interpretações e produção de sentido sobre os dados capturados; para obtenção de processos de circulação com alguma competência de estabilidade; para angariar credibilidade; e finalmente, para manter o compromisso de proteção das fontes.

Aparece aqui, com clareza, a diferença entre informação (como conjunto de dados a respeito de temas do mundo e ações da sociedade); e os processos comunicacionais. Na informação, trata-se apenas de dados, que entram na lógica da passagem - em que nada se modifica, na transmissão entre o ponto de saída e o ponto de chegada.

$\mathrm{Na}$ comunicação, embora a informação seja tipicamente um elemento presente, a transmissão não basta. $\mathrm{O}$ que caracteriza a

54 O termo "wiki”, a partir de expressão havaiana, corresponde nas redes informatizadas a características de rapidez, sistema aberto, edição coletiva e processos colaborativos. 
comunicação, ao contrário, são o gesto interpretativo, a produção conjunta de sentidos (mesmo se tensa e tentativa), a agregação de outras perspectivas, as modificações em processo (ao inverso de entrega pronta); e uma circulação que se faz atravessando ambientes e acervos de densidade e composição variável, incidindo sobre esses contextos e recebendo deles diversas leituras e sentidos múltiplos.

Aparentemente, Assange acreditava que tais processos ocorreriam, produtivamente, em modo colaborativo e espontâneo - o que lhe permitiria dar ênfase ao esforço de disponibilizar. Isso não significa, é claro, que sua ação fosse meramente informativa. $O$ simples fato de desviar informações de um circuito de segredo para torná-lo acessível em circuito aberto é já uma ação política e transformadora, em defesa da transparência e a favor da esfera pública. Como nota o capítulo, Assange e o Wikileaks não se põem apenas como fonte para circuitos noticiosos: desenvolvem uma política própria que facilmente entra em conflito com os campos sociais estabelecidos - inclusive o da própria grande imprensa.

Assim, embora os vazamentos não tenham produzido aquelas ações espontâneas, em volume, sentido e rapidez pretendidos, a disponibilização de dados vazados gerou um forte atravessamento de campos sociais: político, econômico, diplomático e do jornalismo estabelecido - constituindo, como o capítulo mostra, um verdadeiro ecossistema, que evidencia espaços de receptividade social para seus objetivos e procedimentos.

O segundo caso observado apresenta processos complementares que enriquecem a experiência e a invenção social do processo. Leon mostra que os vazamentos efetuados por Edward Snowden especificam diferentemente a experiência social. Uma primeira especificidade foi a de buscar acionar diretamente, dentro do jornalismo estabelecido, setores mais promissores para seus objetivos - assegurando assim a presença de circuitos já dados, para o desvio 
dos circuitos do segredo. Um segundo aspecto foi a exposição do ponto de origem do vazamento, o próprio Snowden, como responsável por este e pela sistematização de dados - o que se torna diretamente notícia, conforme padrões habituais do jornalismo.

O capítulo mostra ainda outra especificidade importante, que é o desdobramento do enfoque informativo: ao lado dos documentos, aparecem informações sobre o próprio processo de geração dos dados dentro do sistema de vigilância, assim como sobre objetivos e usos feitos de tais informações - envolvendo, sob a cobertura do segredo, ações ilegais, contrárias ao estado de direito e à privacidade dos cidadãos, e para beneficiar interesses menos defensáveis, sob a justificativa de interesses nacionais americanos.

Essa explicitação desdobra as ações de vazamento em um nível propriamente noticioso; e um nível diretamente político. Com isso se explicita a multiplicidade de circuitos outros e de campos sociais que são atravessados pelos processos de circulação ampliada. Outro aspecto mostrado por Leon evidencia um aperfeiçoamento do "nível de organização do material entregue", o que desenvolve as lógicas interacionais do processo. Esse aspecto é interessante porque implica uma atenção que vai além dos dados - fazendo perceber diretamente os requerimentos da produção de sentido.

Interessantemente, e malgrado o fato de que Snowden buscou a própria imprensa como principal responsável pela circulação da transparência, evidencia-se também aí um atravessamento do campo jornalístico, pela tensão que os materiais trazem aos padrões habituais desse campo. Quando Greenwald, jornalista do The Guardian, observa os "cuidados excessivos" do jornal na publicação das informações, evidencia justamente uma "barreira institucional".

A última experiência que aparece no capítulo é a do próprio Greenwald, na constituição de uma plataforma para assegurar um sistema de relações interacionais pertinentes ao processo. $\mathrm{O}$ 
capítulo explicita essas características: além da disponibilização de documentos e do trabalho jornalístico habitual, participação de especialistas externos com conhecimentos de área, composição diversificada da equipe e espaço para interação de leitores. As lógicas comunicacionais da plataforma envolvem uma vocação crítica - uma perspectiva com critérios analíticos para interpretação e produção de sentido; defesa do valor de transparência, cobrança de accountability.

Duas proposições do capítulo devem ser destacadas, nesse aspecto. Leon Rabelo observa que a tentativa do The Intercept "não é a de criar uma ferramenta tecnológica de última geração, como foi no caso do Wikileaks. Trata-se antes de criar um espaço interacional que permita a agregação de experiências diversas". E ainda, que a "pretensão do The Intercept é ser, ao menos potencialmente, um dispositivo agregador da confiabilidade noticiosa e articulação de atenção pública" (grifo no original).

Essa perspectiva evidencia desenvolvimentos da invenção social em curso, partindo do vazamento enquanto desvio de circuito. Essa ação comunicacional é ampliada, no caso Snowden, pelo desvelamento dos meandros de um dispositivo de captura e usos contrários ao estado de direito, que é protegido por um "circuito de segredo". No terceiro caso, de Greenwald, aparentemente mais ancorado em processos jornalísticos, podemos na verdade perceber uma elaboração mais complexa, em que lógicas de jornalismo são articuladas com processos mais especificamente focados em uma circulação requerida para os objetivos sociais e políticos defendidos. Isso fica evidente, no texto, tanto pela composição da equipe do The Intercept; como no próprio debate sobre se Greenwald seria de fato um jornalista ou um ativista.

Para além da disponibilização de dados e da geração de processos de circulação que contestam os circuitos do segredo, 
mostra-se, no conjunto de casos, um trabalho socialmente cumulativo na gestação de dispositivos interacionais e de circuitos com lógicas interacionais ajustadas à transferência de políticas do segredo para processos de esfera pública. 


\section{Redes sociais: um perfil no Facebook}

Caroline Casali

\section{Notas iniciais sobre tecnologia e dispositivo interacional}

Desde as primeiras invenções de ferramentas que serviram como extensão do homem, duas atitudes contrapostas são reiteradamente assumidas: de entusiasmo e de medo. A história dos meios de comunicação de massa está repleta dessas angústias.

Quando o rádio ainda dava seus primeiros passos na conquista de grandes audiências, em 1938, a leitura da narrativa ficcional Guerra dos Mundos, na CBS estadunidense, gerou alvoroço. Dois anos depois, em 1940, Chaplin discursava palavras de ordem, ao final de $\mathrm{O}$ Grande Ditador, dizendo que a aviação e o rádio nos aproximaram ainda mais com o intuito de uma sociedade mais amável. A televisão, por sua vez, continua sendo apontada, constantemente, ora como difusora de cultura, ora como ditadora de padrões.

As dicotomias nas análises do uso de tecnologias para a comunicação permanecem na cultura digital - inovações tecnológicas avançam com intensidade, mas os discursos sobre elas parecem perceber apenas dois polos para sua configuração na sociedade: a tecnologia como ferramenta adaptável ao uso do homem ou como configuradora de uma sociedade que é refém de seu uso. Trata-se, afinal, da dicotomia assinalada por Umberto Eco (1993), entre apocalípticos e integrados. 
Quando falamos em redes sociais ${ }^{55}$, esses discursos também se revelam: em uma extremidade, pensadores glorificam sociabilidades que só acontecem, segundo eles, pelas oportunidades tecnológicas; por outro lado, há quem acuse a comunicação que acontece via tablets ou smartphones de promotora de relações efêmeras, superficiais ou simplesmente maniqueístas.

Em contraposição a tais perspectivas, busco problematizar os discursos extremistas sobre o uso de redes sociais, analisando fluxos comunicacionais nele envolvidos. O que pretendo, nessa análise, é enfatizar relações entre circuitos comunicacionais existentes fora das redes e fluxos empreendidos nas redes. Por isso, inicio destacando dois pontos fundamentais à análise: (1) a existência de interações heterogêneas a partir das potencialidades experimentadas pelas redes sociais, e (2) a prioridade que os sujeitos conferem, nessas experiências, às relações já efetivadas em outros circuitos.

Sobre as interações heterogêneas, Recuero (2013) já destacava a funcionalidade das conversações em rede.

Com isso, temos o surgimento de conversações em rede, práticas coletivas, onde a conversação é acessível a diferentes grupos, interconectados dentro de uma mesma rede, cuja infra-estrutura está proporcionada pelos sites de rede social. Vemos essas conversações em todo o lugar: são aquelas que transcendem os grupos e espalham-se pelas redes, seja através das práticas comunicativas

55 Entendemos, a partir da conceituação de Recuero (2013), que o uso adequado do termo seria "sites de redes sociais", contudo, abreviamos a terminologia para o uso comum "redes sociais". Para Recuero (2013), que cita a definição de Boyd e Ellison (2007), sites de redes sociais são aquelas ferramentas que permitiriam aos seus usuários (1) a criação de um perfil individualizado, (2) a publicização de suas redes sociais e (3) a interação. Recuero ainda complementa que os usuários não só utilizam essas redes como também as modificam, de maneira que as redes sociais online sejam cada vez mais interconectadas. 
características das ferramentas (como "curtir" ou "dividir" uma conversação com a rede no Facebook, retuitar uma informação para sua rede no Twitter e etc.). (Recuero, 2013, p.02).

Embora a autora atribua as conversações heterogêneas a potencialidades da infraestrutura das redes sociais, acredito que não são os aparatos digitais de rede que direcionam a conversação desses diferentes grupos. A rede social não provoca circuitos próprios, funciona antes como um espaço em que fluxos comunicacionais são estabelecidos em relação a circuitos já existentes na sociedade ou em experimentação a partir de múltiplas dinâmicas sociais - via dispositivos interacionais que se constituem na rede, mas não são gerados por esta.

Cada episódio comunicacional, na sua prática de fenômeno em ação, recorre a determinadas matrizes interacionais e modos práticos compartilhados para fazer avançar a interação. Tais matrizes - culturalmente disponíveis no ambiente social (e em constante reelaboração e invenção) correspondem ao que chamamos aqui de "dispositivos interacionais”. (Braga, 2011b, p.05).

Então, ao analisar o fenômeno comunicacional nas redes sociais a partir dos fluxos comunicacionais em uma página de perfil no Facebook ${ }^{56}$, percebo que a matriz organizadora desses fluxos não são as tecnologias de rede em si, mas sim o conjunto de usuários, que opera e organiza suas relações, acionando diferentes potencialidades daquele espaço.

56 Facebook é site e serviço de rede social lançado em fevereiro de 2004, operado e de propriedade privada da Facebook Inc. 
Dentro de um processo tecnológico geral, que oferece suas características materiais para interações muito diversificadas, o que procuro observar são estruturas, códigos, estratégias que se articulam com aquelas potencialidades tecnológicas para, direcionando-as, produzir um conjunto específico de episódios comunicacionais - na forma de um dispositivo interacional. Busco apreender interações, segundo as especificidades de um caso: o perfil da docente de Jornalismo, Márcia Franz Amaral ${ }^{57}$, no Facebook ${ }^{58}$.

\section{Dispositivo interacional no Facebook: análise do perfil Márcia Franz Amaral}

Para analisar os fluxos comunicacionais empreendidos a partir do perfil pessoal de Márcia Franz Amaral no Facebook, optei pelo estudo de um período específico de atualizações da página: o mês que sucedeu o incêndio na boate Kiss, tragédia ocorrida em 27 de janeiro de 2013 e que vitimou fatalmente 242 pessoas. Trata-se, portanto, de analisar um ambiente no qual Márcia, que participa de circuitos institucionalizados de saberes em Jornalismo, empreende diálogos com profissionais da comunicação, e/ou acadêmicos dessa área, mas também com sujeitos de outras áreas do conhecimento interações, portanto, heterogêneas.

Com vistas a caracterizar as interações realizadas pela docente no período, classifiquei previamente as postagens efetuadas em

57 Márcia Franz Amaral é docente do Departamento de Ciências da Comunicação do Centro de Ciências Sociais e Humanas da Universidade Federal de Santa Maria (UFSM) e do Programa de Pós-Graduação em Comunicação da UFSM, e líder do grupo de pesquisa Estudos de Jornalismo (CNPq/UFSM).

58 O perfil de Márcia Franz Amaral foi também objeto de minha Tese de Doutoramento (Casali, 2014), que traz uma análise mais detalhada das articulações e tensionamentos ali empreendidas. 
duas categorias: (1) postagens originais e (2) compartilhamentos - considerando que postagens originais são aquelas realizadas na linha do tempo da própria página, pela usuária, enquanto que compartilhamentos são postagens derivadas de outros perfis do Facebook. Nessa primeira classificação, observei que, das 133 postagens realizadas no período, 39 foram proposições originais da docente e outras 94 postagens derivaram de outros perfis.

Essa primeira inferência vem no sentido de confirmar as conversações em rede que se efetivam a partir de potencialidades oferecidas pelos sites de redes sociais - como as ferramentas de curtir e compartilhar. Claro, nesse sentido a questão tecnológica salta aos olhos, porque permite uma circulação muito maior dos assuntos levantados nas redes sociais.

Se as ferramentas de curtir e compartilhar funcionam já no espaço interno do Facebook, quando consideramos as interações entre diferentes redes sociais falamos de circulação ainda maior. Existe, por exemplo, a possibilidade de que postagens realizadas em outras redes como Twitter ${ }^{59}$ ou Instagram ${ }^{60}$ sejam duplicadas no Facebook, sem contar que a maioria dos sites de notícias oferece links para que suas publicações sejam compartilhadas nas redes sociais dos leitores.

Cabe destacar, por outro lado, que as postagens compartilhadas pelos usuários se dão no sentido de reforçar essa identidade, assumida por eles nas redes sociais. Não se trata simplesmente de duplicar as informações a esmo, mas de usá-las em favor de vontades, desejos e experiências que o usuário já traz de circuitos dos

59 Twitter é uma rede social e servidor para microblogging lançado em 2006, que permite ao usuário enviar e receber atualizações em textos com até 140 caracteres.

60 Instagram, lançada em 2010, é uma rede social gratuita para compartilhamento de fotos e vídeos, que podem ser comentados ou curtidos pelos seguidores da conta do usuário. 
quais participa nas relações presenciais. Quando Márcia Franz Amaral escolhe as publicações que quer partilhar, ela deixa clara a legitimação de certo perfil, que nesse estudo é o perfil docente.

Ao olhar para as postagens compartilhadas por Márcia, buscando regularidades, percebo que a maioria de suas interações se dá a partir de circuitos profissionais. Pude segmentar seus compartilhamentos em cinco categorias: (1) de meios de comunicação de massa (notícias); (2) de perfis acadêmicos; (3) de perfis profissionais; (4) de perfis amadores; e (5) de perfis institucionais, conforme demonstra a Figura 1.

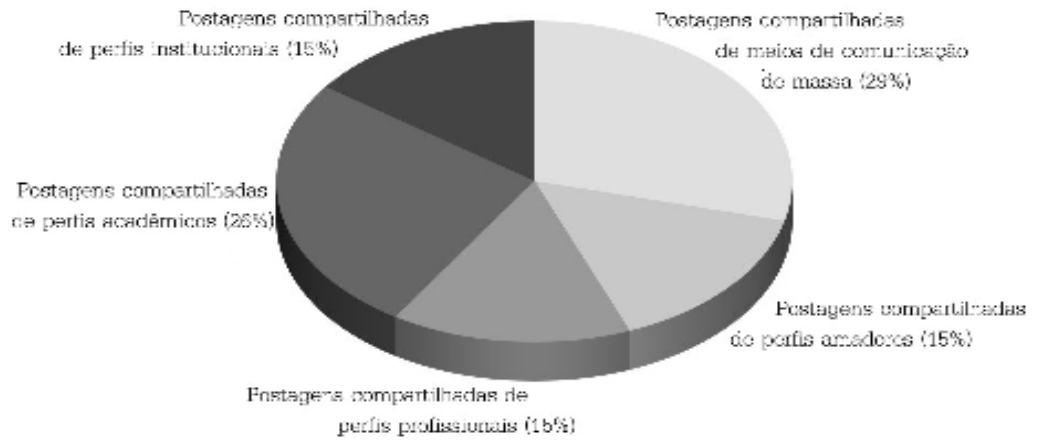

Figura 1: Gráfico de postagens compartilhadas por Márcia Franz Amaral, de 27 de janeiro a 28 de fevereiro de 2013.

Destaco, claro, que essa categorização é de cunho sociológico e necessária apenas para traçar um mapa de relações; contudo não se pretende definitiva nem excludente de outras interações estabelecidas por Márcia no Facebook. Sobre as categorias, entendemos como compartilhamentos de meios de comunicação de massa a duplicação de notícias veiculadas em sites ou páginas oficiais dos meios de comunicação no Facebook; como de perfis acadêmicos, foram considerados os compartilhamentos realizados a partir de 
publicações de usuários que mantém relação profissional e acadêmica com Márcia Franz Amaral fora do ambiente virtual, o que se pode verificar pela forma de tratamento entre os usuários; como de perfis profissionais são considerados os compartilhamentos derivados de profissionais da comunicação, dentre os quais se destacam ex-alunos da docente; já de perfis amadores foram os compartilhamentos derivados de amigos de Márcia cuja relação acadêmica não foi detectada; e, enfim, como de perfis institucionais, foram tomados os compartilhamentos realizados a partir de postagens de páginas oficiais de instituições no Facebook, dentre as quais se destacam páginas de eventos em Comunicação ou de outras universidades.

De acordo com a Figura 1, 25\% dos compartilhamentos são derivados diretamente de perfis acadêmicos, organizando fluxos acadêmicos fora dos espaços formais da universidade. Pode-se considerar, ainda, que os compartilhamentos de perfis institucionais são quase em sua totalidade derivados de instituições de ensino, pesquisa e/ou extensão e que os compartilhamentos de profissionais da Comunicação representam o contato de Márcia com ex-alunos. Dito isso, verifica-se que $56 \%$ das interações estabelecidas pela docente em sua página, são diretamente ligadas a sua vida profissional como docente e pesquisadora de Jornalismo, observando, além disso, que grande parte dos compartilhamentos de notícias de meios de comunicação de massa menciona acadêmicos ou egressos de Jornalismo.

Molda-se via Facebook, então, uma complexa rede de conexões acadêmicas fora do espaço institucionalmente direcionado para isso - a universidade. Nesse sentido, destaca-se que, mesmo diante de possibilidades de interações heterogêneas, a maior parte das relações de Márcia Franz Amaral no Facebook se coloca em relação às interações presenciais exercidas por ela. Dentre esses compartilhamentos estão: divulgação de eventos e oportunidades 
acadêmicas, tais como a chamada para bolsas de estudo em jornalismo ambiental (que contou com a curtida e compartilhamento de uma ex-aluna de Márcia), a veiculação de oportunidade de estágio em comunicação no Brasil (que foi compartilhada por outras duas docentes - da UFSM e da Universidade Franciscana), a divulgação de um artigo publicado originalmente no Boletim da Universidade Federal de Minas Gerais e que trata do ritmo de produção da pesquisa acadêmica no Brasil, a divulgação de inscrições para o Festival do Minuto ${ }^{61}$, a chamada para inscrição de trabalhos na Revista Rizoma $^{62}$, e a divulgação do calendário acadêmico 2013 da UFSM. Por isso, podemos entender que a matriz que organiza as conversações no Facebook, nesse caso, é o perfil da usuária - que coloca em relação amadores e acadêmicos, graduandos e já graduados.

Vejamos alguns exemplos de como isso acontece em compartilhamentos de perfis acadêmicos, lembrando que, nesse ambiente, evidenciam-se dois tipos diferentes de relações: docente-docente e docente-discente.

As relações entre docentes permitem inferir um enfoque maior na promoção do contato do que na produção de circuitos para o Facebook. Exemplo disso é que, em meio às postagens sobre a tragédia, em 12 de fevereiro de 2013, Márcia recebe o convite do docente da Universidade de Santa Cruz do Sul (UNISC), Demétrio Soster, para o lançamento do livro "Tempo Horizontal", em que Demétrio publica suas poesias, o que indica que a rede social serve ao estreitamento de relações acadêmicas. Márcia, inclusive, curtiu a publicação de Demétrio, legitimando o contato.

61 Festival virtual de vídeos produzidos com durações de tempo variadas. Disponível em: http://www.festivaldominuto.com.br/ . Acesso em: 15 de junho de 2013; 13:00.

62 Publicação científica do Departamento de Comunicação da Universidade de Santa Cruz do Sul (UNISC). Disponível em: http://online.unisc.br/seer/index.php/ rizoma. Acesso em: 15 de junho de 2013; 13:00. 
Outras duas postagens evidenciam as interações docentedocente que primam pela manutenção do contato. A primeira refere-se à frase postada pela docente em 26 de fevereiro de 2013: "Cenas insólitas de Santa Maria. Academia, várias pessoas na esteira. $\mathrm{Na}$ TV, Ana Maria Braga entrevista mãe que perdeu filhos na boate Kiss. Olho pro lado, todo mundo chorando". Dentre os comentários dessa postagem está uma ponderação de Carlos Franciscato, Doutor em Comunicação e Cultura Contemporânea e Professor da Universidade Federal de Sergipe, expressando "eu não consigo ler notícias ou imagens sem ficar profundamente tocado", ao que Márcia replica: "Quando vais aparecer Carlos? Avisa! Abraços", e complementa depois "Queremos te ouvir no curso de Jornalismo." Percebemos, aqui, um diálogo que se estabelece para o estreitamento da relação acadêmica e não, necessariamente, para o aprofundamento do tema inicialmente exposto naquele espaço: as cenas insólitas de Santa Maria por ocasião da tragédia.

Da mesma forma quando, em 28 de janeiro de 2013, Márcia desabafa suas impressões sobre a caminhada pela paz, ocorrida em Santa Maria naquela noite, os comentários demonstram solidariedade sem que necessariamente questões centrais do comentário de Márcia sejam aprofundadas (Figura 2).

Márcia Franz Amaral (28 de janeiro):

Entre os colegas que encontrei na caminhada, uma pergunta... como voltar a dar aulas depois de tudo? Como cuidar de uma gurizada triste e desamparada que precisa do colo de seus pais?

Curtir: 38 Comentar: 11

Figura 2: Postagem original de Márcia Amaral sobre a volta às aulas após a tragédia da boate Kiss, em sua página pessoal no Facebook. 
Dos 11 comentários informados na Figura 2, sete são de docentes da Universidade Federal de Santa Maria e de outras universidades do Rio Grande do Sul, que se solidarizam à preocupação de Márcia e comentam que a dúvida que a perturbava seria de todo o coletivo. Destaca-se a fala de um professor da Universidade Federal do Rio Grande do Sul: "o semestre, já torto e complicado, acabou. Como cobrar presença, assiduidade e comprometimento quando tudo parece sem sentido?". O docente em questão revela, em seu comentário, a condição ímpar do semestre em curso devido à greve nas universidades federais brasileiras em 2012 - mas essa discussão não é levada adiante e permanece a sensação de que o lamento de Márcia se constitui em pergunta retórica.

As interações realizadas ali, então, se dão em função de Márcia, e não da produção de circuitos no e para o Facebook - prima-se pela preservação das relações com a docente em sua função de docente. Considera-se, dessa forma, que o modo prático que opera as relações estabelecidas naquela página é o perfil de Márcia, e não apenas a rede social em si - esta funciona como possibilidade para o dispositivo interacional. Braga (capítulo 3, p. 70) expõe justamente que "os dispositivos interacionais são modulados pelos contextos e processos instituídos ou experimentais específicos em cujo ambiente ou referência se desenvolvem".

Interessa perceber, também, uma função diferente nas relações docente-discente, mas que ainda preserva o caráter do perfil como "matriz organizadora das relações". Os fluxos docente-discentes, no Facebook, parecem funcionar dando maior destaque à lógica de controle sobre a produção de saberes do que à de manutenção do contato. Dois compartilhamentos endereçados a orientandas de Márcia chamam atenção para isso. Dois dias após a tragédia, Márcia realiza a primeira postagem que não trata 
do incêndio: recomendava, a duas alunas do Programa de PósGraduação em Comunicação Midiática da UFSM, um evento de Comunicação - a Jornada de Comunicação de Crises, que se realizaria em Madri/Espanha no dia 14 de fevereiro de 2013 (Figura 3).

Márcia Franz Amaral (29 de janeiro):

Para A. D. e M. L.

Top comunicación - Inscribete (grátis) a La Jornada sobre Comunicación de Crisis de Aleph Comunicación www.topcomunicacion.com

Comentar: 2

Figura 3: Compartilhamento de Márcia Amaral endereçado a duas orientandas, em sua página pessoal no Facebook.

O fato de abrir espaço em seus desabafos para divulgar uma Jornada de Comunicação de Crises a duas orientandas suas no Programa de Pós-Graduação em Comunicação da UFSM indica a importância conferida por Márcia aos circuitos dos quais participa fora das redes sociais. Além disso, quando uma das orientandas responde prontamente justificando que não poderia participar em função de compromissos assumidos com a docência em outra universidade, e introduz seu texto com a expressão "Profa. Márcia", se evidencia o espaço de controle que a docente exerce enquanto orientadora no PPG e que se duplica nesse ambiente virtual.

Nesse mesmo sentido, em 07 de fevereiro de 2013, Márcia compartilhou um artigo do Blog Cultura Mídia e Educação, intitulado "Mídia e Educação: existirá um jornalismo de prevenção?", referindo-se às mesmas alunas do Programa de Pós-Graduação na introdução da postagem (Figura 4). 
Márcia Franz Amaral compartilhou um link via Portal de La Comunicación InCom-UAB (7 de fevereiro):

Para A. D. e M. L.

Mídia e Educação: Existirá um jornalismo de prevenção? culturamidiaeducacao.blogspot.com.es

Curtir: 1 Comentar: 1 Compartilhar: 1

A. D. curtiu isto.

M. L: professora lido. Achei muito legal. Estou organizando algumas ideias para escrever artigo para Intercom. Espero levar no início das aulas para discutirmos juntas.

8 de fevereiro, às 10:04.

Curtir: 1

Figura 4: Postagem de Márcia Amaral indicando um texto a duas orientandas, em sua página pessoal no Facebook.

Interessa perceber, nesse caso, três diferentes interações: a curtida de uma das alunas citadas; o comentário da segunda aluna citada; e o compartilhamento da postagem por outra docente de Jornalismo.

Sobre a primeira interação, observa-se que, ao curtir a postagem sem comentar nada a seu respeito, uma das alunas citadas busca dar ciência sobre a leitura do texto a partir das ferramentas que aquele espaço proporciona - o Facebook permite, por meio da opção curtir, que afirmemos nossa leitura, mesmo sem o prolongamento do diálogo. Nesse sentido, ainda que o núcleo do dispositivo interacional, enquanto matriz organizadora das interações, seja o perfil de Márcia, a rede social, em si, confere certas características às relações estabelecidas. $\mathrm{O}$ ambiente no qual as interações se elaboram compõe o dispositivo.

Já o comentário da segunda aluna citada indica novamente uma interação que deriva do circuito externo à rede social - a universidade. Essa interação, embora esteja nos moldes da ferramenta 
comentar, acontece respeitando as funções dos sujeitos na instância acadêmica; vejamos que a aluna inicia seu comentário se referindo ao perfil de Márcia como "professora” e, em resposta à orientação dada, afirma que "está organizando algumas ideias para escrever artigo para Intercom”. É interessante perceber que quando as postagens são endereçadas assumem quase que um caráter de orientação de pesquisa - formando um fluxo comunicacional com fins acadêmicos fora do espaço universitário. $\mathrm{E}$ Márcia exerce com consciência esse papel de mediação; em certa publicação ela inclusive afirma: "Amigos, me desculpem, sei que estão todos cansados, mas como professora de jornalismo, com um perfil seguido por muitos alunos, não posso deixar de compartilhar as reflexões que nos acompanharão por muito tempo no Curso de Jornalismo da UFSM.” (grifos meus).

Por fim, quanto ao compartilhamento do artigo recomendado por uma docente não citada na postagem, é interessante perceber o que acontece na releitura da publicação. A docente Luciana, ao compartilhar o link veiculado por Márcia, cita um parágrafo do artigo, dando destaque à reflexão sobre o jornalismo atual. Dentre os usuários que curtem a postagem de Luciana, está uma senhora não formada em comunicação - portanto considerada, aqui, amadora na área. Vejamos que, nesse caso, se confirma, mais uma vez, o caráter de conversações heterogêneas nas redes sociais. Contudo, não há como prever em que medida essas conversações ultrapassam o sentido fático.

À parte disso, interessa perceber como, a partir do perfil de Márcia Amaral, outros fluxos foram acionados, colocando em interação pesquisadores de comunicação e amadores. Sobre isso, surpreende a maneira como os amadores discutem questões midiáticas mencionadas. Em 12 de fevereiro de 2013, Márcia enunciou: 
"Boquiaberta: vi um programa ontem chamado Mulheres Ricas ${ }^{63}$. Patético, deprimente, ridículo. Como somos passivos ao permitir coisas assim na televisão brasileira? Como deixar aquelas mulheres abrirem a boca em rede nacional? O que dizem, pensam e fazem são ofensas para a maioria da população.", em postagem no Facebook (Figura 5).

Márcia Franz Amaral (12 de fevereiro de 2013)

Boquiaberta: vi um programa ontem chamado Mulheres Ricas. Patético, deprimente, ridículo. Como somos passivos ao permitir coisas assim na televisão brasileira? Como deixar aquelas mulheres abrir a boca em rede nacional? O que dizem, pensam e fazem são ofensas para a maioria da população.

L.C, C.T. e outras 17 pessoas curtiram isso.

Curtir: 19 Comentar: 7

C.M. Segunda temporada, se não me engano... (12 de fevereiro, de 2013 , às $17: 37$ )

Curtir: 1

L.C. Ontem não tinha nada $\mathrm{p}$ ver na $\mathrm{TV}$, acabei vendo um pouco dessa porcaria, tbém. (12 de fevereiro de 2013, às 07:53).

Curtir: 1

F.D. É deprimente. (12 de fevereiro de 2013, às 08:26).

Curtir: 1

G.B.G.G. Aí eu me pergunto, que público é este? (12 de fevereiro de 2013, às 09:07).

Curtir: 1

63 Mulheres Ricas é um seriado que está em sua segunda temporada, veiculado pela Rede Bandeirantes de Televisão. Em sua descrição do Programa, o site da Band enuncia: "Em sua segunda temporada, "Mulheres Ricas" já causa burburinho na casa da família brasileira. Seis mulheres ricas e suas rotinas repletas de luxo, glamour e comportamentos imprevisíveis, prometem despertar muitos sentimentos. Há quem as ame, mas também há quem as odeie, e acredite, isso pode acontecer até entre elas mesmas. Menos ostentação e mais conflitos pessoais, é esta a proposta do diretor, Diego Pignataro, para o retorno das ricas.. Disponível em: http://mulheresricas. band.uol.com.br/o-programa.asp. Acesso em: 04 de junho de 2013; 14:00. 
D.C. O pior é que essa droga tem audiência!! Caso contrário não teria a segunda temporada!! Eu vi uns 2 cap da primeira... Vergonha alheia!! (12 de fevereiro de 2013, às09:19)

Curtir: 2

C.T. Semana a semana, vejo muitos comentários aqui no face de pessoas que veem justamente pelo grotesco que é. Acham engraçado e reproduzem muitas das "pérolas" aqui. O problema é que, assim como esses, QUANTOS deixam seus televisores ligados ORDINARIAMENTE naquele canal.

Figura 5: Postagem de Márcia Amaral comentando o Programa Mulheres Ricas, em sua página pessoal no Facebook.

Parece claro que adjetivos como "patético", "deprimente" ou "ridículo" não cabem em textos científicos confeccionados em espaços acadêmicos, contudo seu uso faz emergir as teorias sobre as quais Márcia constrói sua crítica midiática - a superficialidade, a espetacularização, o sensacionalismo, etc. A postagem em questão gerou sete comentários, realizados em sua maioria por profissionais da comunicação e ex-alunos de Márcia, e chama a atenção certa paridade nas teorias acionadas por especialistas e amadores nos comentários.

Vejamos o comentário de uma fisioterapeuta: "O pior é que essa droga tem audiência!! Caso contrário não teria a segunda temporada!! Eu vi uns 2 cap [sic] da primeira.... Vergonha alheia!!”. Ela critica o programa afirmando que, mesmo ruim, existe uma audiência que se mantém fiel e que levou o programa a sua segunda edição. No mesmo sentido, segue o comentário de uma doutoranda em Comunicação pela Universidade Federal do Rio Grande do Sul: "Semana a semana, vejo muitos comentários aqui no face de pessoas que veem justamente pelo grotesco que é. Acham engraçado e reproduzem muitas das "pérolas" aqui. O problema é que, assim como esses, QUANTOS deixam seus televisores 
ligados ORDINARIAMENTE naquele canal, dando audiência para aquilo?!”.

A equivalência dos dois comentários permite inferir que a fisioterapeuta entende a lógica do consumo midiático e, portanto, discute a rotina dos meios de comunicação ainda que não os tenha estudado na academia; ela propõe questões que não foram discutidas até ali, como a relação entre audiência e programação televisiva de má qualidade. Infere-se, a partir dessa observação, que mesmo não sendo da Comunicação, a usuária entra na discussão com propriedade, incluindo informações até então não cogitadas, e o faz a partir de suas "ressonâncias ideológicas".

Portanto, as análises realizadas no período entre 27 de janeiro e 28 de fevereiro de 2013 permitem concluir que o Facebook é um espaço de conversações em rede. Não é, porém, do aparato que emanam circuitos comunicacionais: via Facebook, é Márcia Franz Amaral que se propõe como dispositivo interacional do qual emergem fluxos comunicacionais que respeitam certa ordem institucional e que, ao mesmo tempo, proporcionam o encontro de atores diferenciados em discussões sobre Jornalismo.

Márcia é mulher, mãe ${ }^{64}$, docente, cidadã, e todos esses papéis a compõem enquanto núcleo de um dispositivo ${ }^{65}$. É interessante per-

64 Em 06 de fevereiro de 2013, em provável referência a seu filho adolescente, Márcia enunciou: "Absurdo nosso sistema educacional que exige que um jovem de 16 anos já tenha que definir seu futuro profissional e escolher estratégias para alcançar o que supostamente "escolheu". \#unidunitê". A discussão, aí, se refere ao sistema educacional brasileiro, principalmente no que concerne ao ensino fundamental e médio. Nos comentários, ex-alunos de Márcia lembram suas decisões precoces e amigos aconselham consultoria psicológica à família. É interessante a constatação de que, embora a postagem seja exclusivamente de conteúdo familiar, também colegas de profissão e ex-alunos curtem a publicação; o fato revela certa liberdade de alunos e ex-alunos em conhecerem a vida privada da docente e opinarem sobre ela.

65 Márcia atua como figura nuclear dos episódios (e do dispositivo correspondente), por isso cabe nomear o dispositivo por seu nome. 
ceber justamente a maneira como essas relações docente-docente, docente-discente, docente-egressos, via Facebook, se dão em fluxos heterogêneos, porque são informais, mas respeitam certa ordem institucional, porque revelam conexões profissionais e de amizade e, principalmente, porque se oferecem também como insumo para diálogos com amadores.

\section{Considerações sobre o dispositivo interacional observado no Facebook}

Verificam-se, a partir das análises realizadas, três características bem marcadas do "dispositivo Márcia Franz Amaral" na rede social Facebook:

1. existem conversações heterogêneas a partir das interações empreendidas no perfil da docente no Facebook;

2. essas interações, via dispositivo, respeitam certa ordem já estipulada em circuitos externos à rede,

3. ao mesmo tempo em que acontecem a partir das ferramentas disponibilizadas pela rede social.

Nesse sentido, cabe destacar que as comunicações ali estabelecidas funcionam como processos tentativos, sem obedecer estreitamente a uma estrutura. É justamente o que Braga destaca sobre o caráter não estruturalista do dispositivo interacional.

Outro aspecto que deve ser sublinhado, no dispositivo, é sua contraposição a estrutura em sentido estruturalista - em oposição à imanência desta, prévia e determinante sobre o que nela é moldado. Com os dispositivos, o que temos é antes uma organização ad-hoc, prática, pragmática mesmo, que funciona enquanto funciona, recuperando portanto sua historicidade. (Braga, capítulo 1, p. 35). 
Ao tratar do dispositivo interacional em redes sociais - estudando uma situação comunicacional em específico - corroboro com Braga, para quem o dispositivo não coloca em separação estrutura e processo, mas possibilita interações que acontecem em função de ambos. Por isso mesmo, reconhecendo uma incidência das características tecnológicas do aparato Facebook no processo interacional, é importante, entretanto, evitar atribuir a este um papel exclusivamente determinante nas interações aí realizadas.

Constato que as interações realizadas no perfil de Márcia Amaral no Facebook acontecem a partir de ferramentas disponibilizadas pela estrutura da rede social; contudo as lógicas ali empreendidas obedecem igualmente a processos exercidos em circuitos extra rede - que redirecionam as potencialidades de sua tecnologia.

Dessa forma, não cabe considerar o Facebook como dispositivo interacional, afinal é o perfil de Márcia que funciona como matriz organizadora dos processos tentativos que acontecem alique ora são mais informais, ora são mais "ancorados em repetições e automatismos" (Braga, 2011b, p.10). O site de rede social é parte do dispositivo, mas são os processos comunicacionais que se estabelecem a partir dele que o caracterizam.

\section{Nota de Agradecimento:}

Agradecemos à Professora Márcia Franz Amaral a autorização para este estudo, assim como sua presença na Tese de Doutoramento defendida em 2014. 


\title{
Suíte $\mathbf{n}^{2} 2$
}

\section{"Redes sociais: um perfil no Facebook", de Caroline Casali}

\author{
José Luiz Braga
}

O texto de Caroline Casali prepara o leitor para seu objeto indicando dicotomias de referência frequente, que aparecem na forma de "explicações" prontas diante de novas experiências sociais - mormente quando relacionadas a tecnologias que parecem mudar radicalmente o modo de fazer as coisas. Duas dicotomias são referidas na introdução: aquela em que se contrapõem entusiasmo e medo diante de novas tecnologias; e outra, em que se atribui aos aparatos tecnológicos uma ação determinista sobre circuitos e usuários, versus uma ação independente pelos circuitos e usuários.

Tanto a perspectiva referida aos apocalípticos e integrados, de Umberto Eco, como a que se contrapõe ao poder determinante das tecnologias, encaminham o leitor para um caso concreto em que se evidenciam respostas mais sutis - e que por isso mesmo se apresentam com maior variação.

$\mathrm{Na}$ abordagem do caso em estudo, o texto dilui outras dicotomias frequentes - o que faz aquela abertura do capítulo se mostrar estimuladora de um olhar lúcido para o exame das questões de interação. Outras duas disjunções habituais têm igualmente sua superação mostrada no texto: a separação ocorrente na cultura, que distingue fortemente proposições de especialistas por um lado e falas leigas ou amadoras, por outro; e uma tendência - não rara de exacerbar o virtual e as redes informatizadas como à parte do "mundo real" (IRL). Em todos esses dualismos, o caso estudado por Caroline Casali evidencia que não se trata de optar genericamente 
por uma ou outra angulação: a realidade, com processos mais diversificados, mostra articulações e continuidades entre polos aparentemente opostos.

Uma das questões diz respeito à midiatização da sociedade. Com excessiva frequência, o senso comum - mas também pesquisadores da área - consideram a midiatização da sociedade como a simples presença intensiva dos diversos media - de massa, audiovisuais, digitais, em rede, hipertextuais - que, com suas lógicas próprias, condicionariam todos os processos comunicacionais da sociedade. Nessa perspectiva, as tecnologias aparecem como determinantes e a sociedade como se acolhesse passivamente tais lógicas e processos.

O caso estudado por Carol, diversamente, mostra "que a matriz organizadora desses fluxos não são as tecnologias de rede em si, mas sim o conjunto de usuários, que opera e organiza suas relações, acionando diferentes potencialidades daquele espaço”. A elaboração, através do texto, dessa perspectiva, permite reconfirmar ao final que

não é [... do aparato que emanam circuitos comunicacionais: via Facebook, é Márcia Franz Amaral que se propõe como dispositivo interacional do qual emergem fluxos comunicacionais que respeitam certa ordem institucional e que, ao mesmo tempo, proporcionam o encontro de atores diferenciados em discussões sobre Jornalismo.

A autora justifica assim nomear o dispositivo pela figura nuclear dos episódios estudados ("dispositivo Márcia Franz") e não pelo aparato - pois é o processo interacional que apresenta as especificidades mostradas.

É claro que as funcionalidades técnicas comparecem sempre mas o que direciona a comunicação são os diversos acionamentos 
e objetivos que os usuários dão a tais lógicas (Feenberg, 2005). O aparato oferece funcionalidades e demarca limites. Ambos, funcionalidades e limites, são importantes, é claro - não se justificaria descartar os componentes técnico-midiáticos, que incidem sobre as interações. Os participantes necessariamente negociam com as lógicas do aparato - negociação que vai no sentido de acionar diversificadamente (e se possível, criativamente) as funcionalidades oferecidas; e de trabalhar os limites como desafios, fazendo seus objetivos interacionais enfrentá-los e eventualmente superá-los: por desvios, criações indiretas, elaborações críticas, tratamento ironizante. Tais processos representam dinâmicas interacionais que, embora acionem o tecnológico (seguindo, portanto, suas características), não se tornam exclusivamente dependentes deste.

Seria possível argumentar que o descrito vale para o caso estudado - e que outros casos serão diferentes. Certamente: mas é essa diversidade que evidencia o aparato tecnológico como não determinante, pois se o fosse, todos os casos mostrariam processos interacionais idênticos. Estudar tais variações nos aproxima mais de uma percepção de características da comunicação do que simplesmente atribuir-lhe generalizadamente as lógicas diretamente derivadas da tecnologia acionada.

A superação de dois outros dualismos infusos na cultura comunicacional constrói caracterizadores principais da especificidade do dispositivo Márcia Franz, como mostra o estudo de Caroline. Logo nas "Notas iniciais", a autora destaca a heterogeneidade dos participantes, assim como a prioridade conferida a relações estabelecidas em outros circuitos. É interessante observar, no capítulo, como essas duas lógicas (aceitação da heterogeneidade e comutação entre circuitos) compõem o desenho do dispositivo. $\mathrm{O}$ texto mostra que este 
funciona [...] como um espaço em que fluxos comunicacionais são estabelecidos em relação a circuitos já existentes na sociedade ou em experimentação a partir de múltiplas dinâmicas sociais - via dispositivos interacionais que se constituem na rede, mas não são gerados por esta (grifo no original).

Há então uma continuidade entre o que se passa nas redes informatizadas e as interações "do mundo real". Efetivamente, a relação interacional que constitui o núcleo do dispositivo parece começar por uma relação pedagógica entre a professora, estudantes e orientandos - um processo evidente, no campo acadêmico - que se expande, em camadas sucessivas, para colegas, outras instituições acadêmicas, profissionais de jornalismo, ex-alunos, e finalmente outros participantes mais ou menos indefinidos. Ao mesmo tempo em que essa diversidade expressa a heterogeneidade referida pelo texto, constrói também passagens dinâmicas dos circuitos mais típicos do campo universitário (com a presencialidade da sala de aula) até uma circulação mais difusa, própria dos processos midiáticos. Essa variação é gradual - os processos de rede e os processos individuados (seja pela presença física, seja pela especificidade e direcionamento de falas) não se mostram como dois espaços distintos com passagens controladas entre um e outro, mas ao contrário, como imbricados e mutuamente dependentes.

O dispositivo se mostra, assim, como um processo de expansão e diversificação, em relação a referências interacionais e circuitos mais estabelecidos, englobando e articulando estes - que continuam presentes, portanto, por suas lógicas - com aquelas viabilizadas pelo aparato, segundo articulações específicas do "dispositivo Márcia Franz".

A segunda continuidade enfatizada por Caroline Casali, a partir da evidência da heterogeneidade, é a ultrapassagem de circuitos muito especializados. No dispositivo, não há separação estanque 
entre a fala especialista e a fala amadora. Ao explicitar os diferentes perfis participantes, o texto caracteriza justamente a presença de circuitos variados - desde o propriamente acadêmico, ao profissional, às instituições, aos meios de massa, aos amadores. Isso não leva a uma dispersão temática ao sabor da diversidade dos participantes. Há uma perspectiva segundo a qual os temas são tratados: a visada jornalística, marcada não só como processo de ver o mundo, mas também como objeto per se, como questão a ser refletida. Por outro lado, o capítulo evidencia, em diversos trechos, que não se trata de um dispositivo de especialistas. Há sempre passagens entre um "dentro" e um "fora": da profissão, do ensino acadêmico, das relações professor-aluno, do que se vê na grande mídia, como analista mas também como espectador, de posições escoladas mas também de posições de senso comum esclarecido. Em todos esses processos, se evidenciam lógicas de articulação entre o conhecimento acadêmico, o conhecimento profissional jornalístico, e um conhecimento de leitor, sobre jornalismo.

Isso leva a um tom menos formalizado por lógicas de campo. Justamente, o caso aparece como uma das possibilidades interessantes de atravessamento de campos sociais por circuitos e dispositivos interacionais "em experimentação". É claro, aqui, que esse atravessamento não aparece como problemático para as lógicas do campo acadêmico (embora possa apresentar desafios interessantes).

Lógicas de campos sociais muito estabelecidos tendem a ser dominadas por perfis especialistas - os conhecedores. Assim, o campo médico, o campo psicológico, os espaços profissionais especializados em geral, o espaço acadêmico de formação e de pesquisa. Diversamente, no dispositivo estudado nesse capítulo - e nos circuitos em que ele seja um ponto nodal - aparecem tentativas mais abertas: 
a. uma circulação ampliada de conhecimentos especialistas relevantes, com capilarização para espaços não especialistas, alimentando o conhecimento geral em outros âmbitos sociais, e oferecendo possibilidades de esfera pública, espaços de vida prática, estimulação crítica, e um senso comum esclarecido, relevantes para a cidadania;

b. mas também no sentido inverso - uma circulação dos terrenos do senso comum e da vida prática em direção aos campos especializados (no caso, da academia e da profissão jornalística) que, menos fechados em seu jargão próprio, em sua auto-referencialidade, podem capturar estímulos de renovação e plasticidade reflexiva.

Finalmente, cabe observar as relações entre dispositivos e circuitos, em que o caso evidencia articulações muito claras. $\mathrm{O}$ capítulo mostra âmbitos de circulação em que Márcia Franz vai buscar seus materiais para compartilhamento. Como mostra Carol, "quando Márcia Franz Amaral escolhe as publicações que quer partilhar, ela deixa clara a legitimação de certo perfil, que nesse estudo é o perfil docente". Há um processo de seletividade que participa centralmente das lógicas e da legitimação do dispositivo. As postagens da própria responsável pela página organizam e dão o tom para as interações ocorrentes. Em seguida, essa seleção se enriquece pelas curtidas, comentários e compartilhamentos subsequentes, pelos seguidores da professora, entre colegas professores, profissionais, estudantes e amadores. Com isso, o dispositivo vai alimentar outros e outros circuitos - no processo rizomático frequentemente associado às redes sociais.

Fica muito evidente, aqui, aquela característica que determinados dispositivos podem exercer, enquanto pontos nodais em circuitos sociais de comunicação - captando e selecionando materiais de diferentes circuitos; realizando seleções e agenciamentos 
próprios; e dinamizando e direcionando novas interações em circuitos a jusante. No cruzamento de circuitos diversos, o dispositivo estudado amplia um espaço de fronteira, que se mostra como âmbito de inquirição, reflexão e aprendizagem para a academia. 


\section{Minisséries da TV: um circuito para a história}

Michelli Machado

\section{Introdução}

Nosso foco de observação neste capítulo são produtos midiáticos que funcionam como tratamento ficcional da narrativa histórica, com possíveis reflexos no processo educacional contemporâneo. Embora a virtualização tenha estimulado desenvolvimentos nessa direção, no espaço estabelecido da TV já encontramos a possibilidade de refletir sobre o desenvolvimento de questões de aprendizagem. $\mathrm{O}$ texto se propõe a pensar esse fenômeno pelo estudo de caso de uma minissérie histórica; e de outro programa de TV, que reapresenta sua trama ampliando as questões políticas e culturais tratadas na minissérie.

A experiência destacada para essa observação é a da obra Chiquinha Gonzaga, exibida, pela Rede Globo, em 1999 e de sua reapresentação no programa Faixa Comentada, do Canal Futura, em 2008. Enquanto a minissérie a partir de uma biografia traz questões históricas, políticas e culturais para o cotidiano, o programa Faixa Comentada tem um tom mais pedagógico e busca expressamente ter uma incidência no processo de aprendizagem.

As minisséries de ficção que narram a história por meio da representação midiática da experiência vivida, coletiva e/ou 
individualmente, assumindo um caráter histórico, suscitam polêmicas e debates pelo modo como reconstroem a realidade. $\mathrm{O}$ cuidado, ou não, com os detalhes, a forma como o período é reconstruído, direcionam a recepção solicitada pela obra como leitura poética da história, trazendo, porém, rastros da realidade.

As minisséries, voltadas essencialmente para a narrativa dramática, podem ser consideradas, nessa perspectiva, como núcleo de um dispositivo interacional de entretenimento. Por outro lado, considerando seu elemento de referência histórica (central, para a caracterização do gênero), podemos nos perguntar sobre sua potencialidade para ser tratada, também, como núcleo de um dispositivo interacional de ordem da aprendizagem.

Esse processo que entrevemos nos permite refletir sobre o tema e desenvolver questionamentos. Que potencialidades de aprendizagem se evidenciam, aí? Que elementos podem ser destacados como modo de propor conhecimento? Podemos afirmar que produtos midiáticos "oferecem aprendizagem"? Em síntese: se há um dispositivo interacional de aprendizagem, o que oferece?

\section{Panorama empírico}

O eixo heurístico que aciona essa reflexão é o processo de midiatização da sociedade, que se observa a partir de diversos ângulos comunicacionais, gerando dispositivos interacionais e circuitos que atravessam o campo social. As minisséries históricas acionam um acontecimento real para a construção ficcional de suas narrativas, criando episódios e personagens a partir de situações encontradas em registros e documentos históricos.

Há nas minisséries, que buscam contar episódios da trajetória política e cultural de uma nação, uma costura entre história e romance histórico, que vai tecendo a ficção televisiva baseada em 
um acontecimento. As obras se ancoram em documentos, apresentando-os, seja como recurso expressivo, seja como forma de evidenciação do passado vivido. A distância no tempo representado, entretanto, altera a forma de construção dessas narrativas, trazendo particularidades da cultura brasileira do presente ao modo como estas passagens da história do país são narradas. Esse traço se manifesta seja na própria escolha dos fatos narrados, seja no modo de narrar.

Com a ficcionalização e a possibilidade de dar rosto a figuras históricas, ganham visibilidade personalidades e realidades antes apenas imaginadas, através de relatos. Paralelamente, o fato referido se inscreve em uma narrativa com tensão dramática.

Poder presenciar através da televisão o que frequentemente não é mostrado na história escolar faz das minisséries um veículo de entretenimento e aprendizagem. As versões escolhidas por quem conduz a narrativa ficcional buscam capturar o interesse do público. Essa tendência pode ser observada na escolha dos atores que vivem os personagens históricos, indo de figuras consagradas e queridas pelo público, até anônimos, que são apresentados aos telespectadores pela minissérie, para parecerem mais verossímeis. Em alguns casos, pode ocorrer uma associação do ator com o personagem por parte de público.

É importante voltar o olhar para a questão dos processos de aprendizagem, porque há uma demanda difusa por aprendizagem no país. Desta forma, processos midiáticos, como as minisséries, podem se caracterizar por uma potencialidade de encaixe com algumas características dessa demanda.

As minisséries contribuem para uma percepção de realidade que não tem compromisso com o rigor da descrição histórica, mas sim se propõem como elaboração de sentido - inventado na liberdade da imaginação ou inferido a partir de elementos da realidade. 
As obras vão em busca do não vivido para dar algum sentido ao vivido, onde o tempo presente se explica numa lógica que cruza história e ficção. Nessas releituras, o passado é glamorizado, os padrões de beleza e os comportamentos sociais dos personagens refletem, às vezes, sensibilidades e problemáticas contemporâneas, mais que as questões da época representada.

A minissérie Chiquinha Gonzaga contou a vida da personagem título, de seu nascimento até sua morte. A história é narrada a partir de uma burleta ${ }^{66}$, que se realiza em homenagem a Chiquinha Gonzaga, nesse momento com 87 anos de idade. A trama se inicia quando Chiquinha, já idosa, vai ao teatro assistir sua própria história. A protagonista, vez ou outra, enquanto a encenação transcorre, faz interrupções e comentários sobre o que efetivamente lhe acontecera, e pensa como seria sua vida se tivesse tomado outras decisões. O que a minissérie mostra é, então, construído na forma dessas reminiscências.

A obra é perpassada de acontecimentos históricos do período de vida da compositora, (de 1847 a 1935), entre eles, a Guerra do Paraguai, a Abolição da Escravatura e a Proclamação da República. Todos esses eventos contribuem para que a trama sirva como "onda portadora" de informações históricas.

O programa Faixa Comentada reapresentou a minissérie quase dez anos depois e ampliou sua abordagem no que diz respeito à música, à história e aos bastidores da trama. Através de entrevistas com autor, produtor, diretor, elenco e outras pessoas envolvidas na obra, como especialistas em literatura, história e produção de TV. Ou seja, o programa "age sobre" a obra, e nessa perspectiva ultrapassa uma simples relação entre produção e recepção. Trazendo informações sobre o modo de fazer, sobre as expectativas das

66 Gênero de teatro, com características cômicas e musicais, de origem italiana. 
minisséries, sentidos pretendidos por parte dos criadores e diferentes ângulos de observação, traz a trama para um outro modo de circulação.

\section{A obra Chiquinha Gonzaga}

Chiquinha Gonzaga apresenta aos telespectadores a obra e a vida de Francisca Edwirges Neves Gonzaga. Escrita por Lauro César Muniz, a trama narra, em 38 capítulos, a história de Chiquinha, uma das maiores musicistas brasileiras, tendo como pano de fundo a sociedade carioca do século XIX.

Ao final de cada capítulo da minissérie, uma música diferente de Chiquinha Gonzaga é tocada ao piano, por diversos artistas. A abertura da obra conta também com uma música da compositora, e muitas partituras de piano onde os nomes do elenco vão aparecendo, como se fossem as notas musicais. A forma de abrir e encerrar a minissérie, nos dá um pouco o tom da trama, que relaciona a vida de Chiquinha com suas composições musicais.

O eixo dramático da obra se firma em Chiquinha e tudo mais que a cerca se torna pano de fundo, ambientação. $O$ que importa é contar a história sob o ponto de vista de Francisca, reproduzir seus sentimentos, suas lembranças, suas vontades e suas histórias. Entretanto, a pequena história, a história íntima da vida de Chiquinha se cruza com a história do país, com os acontecimentos marcantes na construção política, social e cultural do Brasil. Chiquinha viveu em um tempo de mudanças e transformações históricas. O surgimento da luz elétrica, a extinção da escravatura e a proclamação de república são alguns fatos importantes para o país, que também trazem consequências para a vida da musicista, e assim, a partir da visão da protagonista, passam a ser narrados. 
A minissérie tem assim abordagem biográfica. Esse tipo de construção narrativa é uma forma simples e eficiente de produzir vínculos entre a protagonista e os telespectadores. Se por um lado a ficcionalização de personagens históricos tende a produção de mitos, por outro, ao narrar um acontecimento a partir dos sentimentos de quem vive a história, a obra se torna o relato da vida de alguém e o espectador, entrando na intimidade de seus dramas, se torna cúmplice do personagem.

O roteiro da trama serve-se do comportamento de Chiquinha, não sintonizado com as normas conservadoras do tempo em que viveu, e busca em sua construção ficcional, dar sentido às atitudes da compositora. Com isso, a eficiência histórico-narrativa é dupla: favorece a identificação dos telespectadores pela relativa proximidade com um comportamento da maestrina e singulariza a personagem pelo contraste que faz com o ambiente de sua época.

A minissérie propõe idas e vindas entre o passado e o presente a partir da memória da musicista. Cenas de Chiquinha idosa, revendo sua história no teatro são costuradas com imagens dela jovem, vivendo sua vida e fazendo suas escolhas. Esse movimento apresenta para os telespectadores as reflexões de Francisca sobre sua história. A partir dessa possibilidade de rever sua trajetória, a obra explica algumas atitudes da protagonista, ao mesmo tempo que redime Chiquinha dos erros cometidos. Esse movimento entre diversas fases de sua vida faz com que na estrutura da narrativa haja um embaralhamento entre ficção e realidade, dentro da obra de ficção que é a minissérie, possibilitando uma percepção de que a vida e a reconstrução da vida trazem pontos de contato, eixos comuns, mas são construções diferentes de um mesmo fato.

A obra explica e justifica algumas atitudes de Chiquinha, como o fato de abandonar os filhos e dar prioridade à carreira. $O$ ponto de conflito se dá, porque embora hoje a liberdade e a independência 
sejam valoráveis, o abandono dos filhos por parte das mulheres que devem sempre ter um estremado instinto maternal - não se apresenta facilmente como aceitável nos padrões predominantes. Dessa forma, apesar de mostrar o abandono dos filhos por parte da heroína, a minissérie reitera muitas vezes seu arrependimento diante de tal atitude e mostra que a musicista tenta, ao longo da vida, muitas vezes se aproximar dos filhos abandonados, mas é sempre impedida por alguém ou mesmo rejeitada pelos filhos, com os quais volta a conviver somente em sua idade adulta, mesmo assim, em relações muito tumultuadas.

A peça de teatro inicia narrando o nascimento de Chiquinha em 1847. A partir dos fatos relatados pela montagem teatral, a memória de Chiquinha é acionada, e à medida que a protagonista relembra o que aconteceu, a história volta a época antiga. A construção de uma história pelo viés da biografia é uma fórmula que tem se repetido, na literatura e em obras televisivas, devido ao apelo de intimidade que esse tipo de texto possibilita. Biografias, por trazerem à tona peculiaridades muito pessoais de personalidades públicas e figuras históricas, costumam interessar leitores e telespectadores, pela sensação de estar conhecendo de forma mais aprofundada o universo particular de pessoas que pareciam distantes do alcance ou convívio pessoal.

$\mathrm{Na}$ cena final, há o encontro das três fases da personagem, sendo que as duas primeiras fases já foram apresentadas pela trama: Chiquinha jovem e adulta. E a terceira é a velhice, momento em que a musicista vai ao teatro rever sua história. Essa terceira é um nível "moldura" que oferece o momento presente da narrativa; as duas outras são fases de memória. Chiquinha vai para casa após o espetáculo em sua homenagem, senta-se na cama e recebe a visita de si mesma em duas outras idades. As três conversam, e a mais velha afirma que elas sempre fizeram o melhor que puderam em tudo, ou 
seja, a obra permite que Chiquinha reflita e se absolva de seus enganos. Antes de morrer, ela pede para que as duas Franciscas, em outras idades, sigam para o carnaval pelas ruas do Rio de Janeiro e em seu epitáfio escrevam: sofri e chorei. Essa frase redime Chiquinha de algumas atitudes julgadas como condenáveis, já que nas narrativas as personagens são resgatadas pelo sofrimento. $\mathrm{E}$ assim a personagem de Chiquinha pode ser perdoada e os telespectadores podem dar sua adesão sem se sentirem incorrendo em um dilema moral.

A produção e a direção de arte da minissérie procuram reconstituir cuidadosamente os objetos de época em cena. Para que a cidade fosse retratada de 1847 a 1935, detalhes como a mudança nos transportes, o surgimento da luz elétrica e as modas que fizeram parte do período foram mostradas. Apesar de ser uma obra que destaca elementos da arte e da cultura brasileira, a minissérie também apresentou discussões políticas.

\section{A circulação da minissérie no Faixa Comentada}

O programa Faixa Comentada possibilitou observar um outro tipo de circulação, que se dá a partir da reapresentação, da revisão do que já foi visto, e de um aprofundamento histórico, cultural e midiático sobre o assunto. No exame da minissérie Chiquinha Gonzaga, traz aos telespectadores um leque de informações extras sobre a trama.

O programa se propõe a refazer o percurso de produção e traz a tona obras antigas e fatos passados sob um novo prisma, ao explorar elementos não trabalhados na obra. Por meio de entrevista com atores, diretor, autor, musicólogos, produtores de arte, historiadores, cenógrafos, entre outros profissionais, é possível ampliar a discussão suscitada pela minissérie. Todas as entrevistas foram produzidas especialmente para o programa. Os depoimentos eram 
individuais, mesclados com cenas que possibilitavam maior ambigüidade de interpretação. O Faixa Comentada ampliou o debate sobre as situações ficcionais da trama, fazendo um paralelo entre os fatos que tem registro histórico e o que foi licença poética do autor.

Em todas as sequências de cenas trabalhadas pelo programa, foi esclarecido pelo autor o que era registro e o que era ficção. Essa discussão, sobre como a ficção se constrói a partir do que existe e intuindo sobre o que não se sabe, mostrou que o ficcional, na minissérie Chiquinha Gonzaga, esteve embasado em possibilidades reais. O autor buscou se aprofundar na personalidade da musicista para imaginar como ela teria reagido a determinadas situações e que histórias íntimas pode ter vivido, sem que nunca tenha havido qualquer registro que comprove isso. $\mathrm{O}$ autor fala da transformação da personalidade em personagens, no momento em que se traz o íntimo, os detalhes, através da criação do ficcional, com base no que pode ter acontecido.

Ao comentar a trama o programa traz esclarecimento sobre determinados ângulos da história. Conta como era a publicação de partituras no Brasil imperial, o que recebiam os músicos e como se deu a mistura de gêneros cultos e afros que compuseram a musicalidade brasileira. A obra abre espaço para comentar o maxixe, gênero do qual Chiquinha se tornou grande compositora e possibilita aprofundar a discussão sobre a censura, e o quanto esta foi danosa para o país. Também suscita o interesse por fotografia e arte, a partir da evolução das técnicas trazida pela minissérie.

As explicações feitas pelo musicólogo, pelo figurinista e pelo historiador buscam sempre mostrar e esclarecer as situações históricas referidas. A Rua do Ouvidor foi recriada pela obra e a confeitaria da trama foi inspirada na Confeitaria Colombo, com influência francesa, e contou até com doces de época. A minissérie quando recircula mostra as condições de vida dos músicos e compositores 
nos anos iniciais da carreira e fala da importância do O Abre Alas para os rumos do carnaval no Brasil.

A circulação da série reacendeu o interesse pelo tema e isso despertou para leitura de obras sobre a musicista, sobre história e sobre a formação da música popular brasileira. $\mathrm{O}$ autor Lauro César Muniz comenta que até o túmulo de Chiquinha voltou a ser visitado com a exibição da minissérie. A reexibição da narrativa no Faixa Comentada tornou a captar olhares para a história da maestrina.

Questões sobre a luta e os resultados do abolicionismo, sobre o movimento abolicionista e suas ligações com o movimento republicano e a importância de figuras históricas como José do Patrocínio, foram trazidas para a discussão pelo programa, que através do historiador, Joel Rufino dos Santos, esclareceu alguns aspectos dessas questões.

O programa Faixa Comentada fez a minissérie Chiquinha Gonzaga circular novamente, nove anos após sua exibição. Essa circulação ampliou a abordagem da trama e possibilitou rever o que já tinha sido visto e ver o que não tinha sido mostrado. $O$ programa usou a minissérie para falar da necessidade de uma obra de época ser fiel ao espírito do tempo que retrata. Apesar de infidelidades cometidas pela ficção, os figurinos, a cenografia, os fatos históricos que ocorrem, paralelamente, a vida de Chiquinha e a chegada do progresso, com os bondes e com a luz elétrica, foram cuidados que trouxeram ao telespectador o realismo da época apresentada pela trama. Tiza de Oliveira falou para o programa sobre o imenso trabalho de produção de arte, reproduzindo fachadas e interiores do Rio de Janeiro imperial.

A obra mostra a transformação da luta pessoal de Chiquinha em uma causa maior pela liberdade, quando por amor a João Batista ela efetivamente tomou sua primeira atitude em favor ao abolicionismo. O programa possibilitou fazer um paralelo entre a paixão de 
Chiquinha por um homem e a paixão pela música, indicando que formavam uma só força irresistível para ela.

É interessante ver como, ao longo do Faixa, os atores vão se posicionando frente às atitudes dos personagens. Odilon Wagner fala das contradições do militar Basileu, pai de Chiquinha. Diz que a filha e o pai se pareciam muito, pois os dois tinham a alma libertária e relembra que seu personagem rompeu com a família para casar-se com uma mestiça, em 1847, quando Chiquinha nasceu. Essa afirmação do ator "dá gancho" para a fala do historiador Rufino, sobre a raridade de casamentos interraciais no século XIX.

No programa Faixa Comentada, as lógicas da circulação buscam um tom pedagógico, por isso as entrevistas trazidas não querem polemizar, mas esclarecer. Os depoimentos buscam sempre o lado positivo do que é mostrado e mesmo as críticas à produção ocorrem de forma amena. A fala de Rufino, sobre o "branqueamento" de Chiquinha, por exemplo, não acontece de forma agressiva, mas numa perspectiva que busca a educação. Ou seja, a intenção do historiador é relembrar as origens negras de Chiquinha, destacando que o branqueamento é ficcional, sem com isso questionar a escolha do autor ou a "verdade" transmitida pela obra. O programa se propõe assim, por meio de uma reapresentação da trama e de entrevistas, reler a história já trabalhada na minissérie pelo viés da atualidade.

\section{Lógicas do objeto e ângulos de reflexão sobre o tema}

A narração da história na televisão propõe por meio de dispositivos técnicos, como som e imagem, reconstruir uma memória que muitas vezes não existe, ou aparece de forma desbotada. $\mathrm{Na}$ verdade, ao dar rostos aos personagens históricos, as minisséries televisivas constroem uma memória borrada, mas em cores vivas, composta de rastros históricos e ficção. 
Essa reapresentação de fatos e figuras reais a partir do imaginário do autor, do produtor e do próprio intérprete, se desenha como outra forma de mostrar a história, por meio da dramatização, o que possibilita outro tipo de aprendizagem, mediada pela televisão. Mais do que apenas informações factuais da história, esses produtos estimulam a absorção de conhecimento, por meio da circulação do programa e de sua abordagem política e cultural. Assim, minisséries históricas trazem em suas narrativas a potencialidade de debater sobre processos sociais, culturais e políticos, que podem agregar base de experiências à vida prática, gerando circuitos que trazem uma parcela, pequena que seja, de sabedoria das coisas da cultura, da sociedade, da história como coisa vivida.

Toda vez que falamos de obras de ficção que partem de acontecimentos reais, ou relatam a vida de uma personagem histórica, há um tipo de aprendizado sobre a história da nação e de figuras importantes na construção política, social, econômica ou cultural do Brasil. Ou seja, este tipo de trama, invariavelmente, oferece mais que entretenimento, embora seja esta sua principal função. $\mathrm{O}$ tipo de aprendizagem gerada e o entendimento da realidade histórica produzida vão depender da capacidade de edição dos telespectadores e de sua bagagem cultural acumulada. Mas todos podem ir além do mero entretenimento para entrever sentidos históricos nas histórias contadas e nos personagens.

Não devemos ignorar a aprendizagem que temos a partir dos meios de comunicação, mas precisamos estar atentos para que sejamos críticos ao que a mídia está transmitindo, uma vez que o aprendizado midiático traz informações que precisam ser organizadas e recicladas na busca por encontrar arte, cultura e conhecimento.

Ao entender o papel das minisséries históricas como uma ponte que liga o presente ao passado, temos a possibilidade de entrever uma parcela de mundo, a partir do período apresentado 
na obra de ficção. Esse movimento pode suscitar uma vontade de conhecer mais, servindo de mola impulsionadora para ampliar o entendimento de alguns fatos da história.

A vinculação entre os telespectadores e as minisséries históricas acontece porque a história contada pela televisão chega pelo ângulo do comportamento pessoal, fazendo relações entre a vida da personagem e processos públicos relevantes. Nesse panorama, são apresentadas questões polêmicas e tensionamentos sociais, a partir da realidade da protagonista, relacionando o cotidiano pessoal da musicista com sua criação artística, por meio de uma narrativa biográfica.

Dessa forma, dá ao telespectador a possibilidade de reconhecer no personagem histórico um outro "eu" - uma pessoa com desejos e inseguranças, como acontece numa história de vida. Esse tipo de construção cria laços de cumplicidade entre o personagem e telespectador, que passa a participar de suas aventuras e se comover com seus dramas. Essa identificação desoficializa a história por meio de uma narrativa "leve" e estimulante, prepara o espectador para acolher o processo histórico.

Ao contar a história nacional, as minisséries históricas dão movimento e cor aos fatos relatados. Assim, produzem narrativas que funcionam de acordo com as dinâmicas televisivas. $\mathrm{O}$ contexto político e cultural de uma determinada época é mostrado no processo de seleção dos acontecimentos, no entanto, não podemos esquecer que alguns aspectos ganham destaque e relevância, enquanto outros são esquecidos. Ao iluminar alguns fatos em detrimento de outros, a história passa a ser entendida sob outra ótica e em perspectiva contemporânea, trazendo o acontecimento histórico para dentro da vida do espectador. Pode-se ter, assim, a expectativa de uma apreensão de história como coisa viva - o que pode criar ou ampliar uma consciência do presente como processo histórico, ao fornecer elementos de comparação. 
Pela possibilidade de ficcionalizar e atualizar os registros da história, as tramas constroem narrativas que mesclam ficção e realidade. E assim a história nacional vai sendo vista, ouvida, debatida e apreendida. É nesse processo de ficção controlada, que as minisséries contam e recontam a história da nação. Montagens, recortes e colagens, embaralhamento de fatos e criação de heróis e heroínas fazem parte da maneira encontrada pela mídia para falar de história.

Nesse processo, o que se ensina e se aprende varia de pessoa para pessoa, em função do grau de envolvimento com a trama e com os fatos narrados. O interessante é observar que a dramatização televisual histórica e seu modo de circulação estão fazendo alguma coisa, estão trazendo para a sociedade uma outra versão dos acontecimentos, uma chance de rever o que já foi visto, ou de conhecer o que ainda não se conhecia. Ao oferecer uma referência histórica, mesmo que indireta, as tramas dão profundidade e relevância aos fatos e criam possibilidades sofisticadas de construção de processos narrativos, numa percepção da história como algo mutável, que sempre pode oferecer outra leitura. 


\title{
Suíte n 3
}

\section{"Minisséries da TV: um circuito para a história", de Michelli Machado}

\author{
José Luiz Braga
}

Michelli Machado observa dois dispositivos como pontos nodais de uma circulação específica enfocada pelo ângulo da aprendizagem - mostrando já uma relação de circulação do primeiro para o segundo, processo acionado pela autora para inferências.

A aprendizagem, assinalada por Michelli, como subsidiária possível do entretenimento, não é de tipo escolar ou "educacional” (em que os principais objetivos seriam de formação) ${ }^{67}$. Duas características, entretanto, justificam as reflexões sobre o circuito no eixo aprendizagem: primeiro, o enquadramento histórico dado à narrativa, a referência, embora romanceada, a uma personagem da realidade e a seus contextos culturais e políticos. Depois, a retomada em outro dispositivo, em que ocorre um "falar sobre" a minissérie, sua feitura e sua relações mistas, entre a factualidade histórica e a narrativa dramática.

A questão que Michelli assume é a de refletir sobre os dois dispositivos, observando aí os processos interacionais e de circulação como casos específicos em que relações de aprendizagem se apresentam como resultante. Nessa perspectiva, que lógicas específicas aparecem? Não se trata, no capítulo, de afirmar que esse ângulo prevalece, mas sim de observar como os diversos elementos da interação se organizam quando vistos em tal perspectiva. Como os

67 Vale assinalar, justamente, que apesar da forte correlação entre "aprender" e "educar", não existe uma articulação sistemática e obrigatória entre esses dois processos humanos (ver Braga, "Aprendizagem versus Educação na Sociedade Mediatizada”, 2002). 
demais componentes do processo interacional se articulam com o eixo da aprendizagem?

A autora assinala, logo de início, ações diversas nos dois dispositivos nodais que mostram a circulação de processos de aprendizagem. Tanto os elementos biográficos como os de âmbito político-cultural oferecem informações referentes a todo um período histórico da vida nacional. Essas informações são envolvidas em elementos narrativos romanceados, com componentes ficcionais. Tal procedimento não caracteriza um dispositivo propriamente original: sabemos de longa data que o "romance histórico" desenvolve estas agregações, assim como, na área audiovisual, o cinema e a própria TV têm trabalhado extensivamente as possibilidades diversas de tal aproximação. Mas justamente, a inserção nesse modelo justifica perceber aí um modo de aprender.

Em alguns aspectos, o elemento narrativo romanceado pode representar um reforço a aprendizagens de ordem prática - isto é, não especializado, não acadêmico - na medida de seu estímulo ao interesse do espectador através da tensão dramática, que prende a atenção. $\mathrm{O}$ foco nos personagens, protagonistas e antagonistas, além do acompanhamento de vidas singulares, marcado como gesto de entretenimento, oferece a referência dos comportamentos e das posições assumidas, das tensões sociais perceptíveis, dos elementos de contexto político-cultural, e de conhecimentos pontuais sobre fatos e processos historicamente situáveis.

Tratando-se, no caso, de biografia parcialmente ficcionalizada de uma artista, seria possível atribuir-lhe menor peso, por contraste com uma história das grandes decisões político-sociais e econômicas. Mas tais aspectos de vida pessoal também engendram nas tramas de grande história, por vínculos de pertencimento ao contexto, uma ação sobre este - no caso, referente à situação feminina, ao racismo, às estruturas da família, à cultura nacional. 
O texto de Michelli mostra bem que o processo vai além de capturar o interesse (que é uma tática do entretenimento para gerar cumplicidade com o espectador). Esse compartilhamento seria a onda portadora para apreensão de processos históricos de entorno. Com as características próprias do televisual e da serialidade, o dispositivo intensamente acionado é o do romance histórico - com o reforço principal, no caso, de não se tratar apenas de personagemtipo em ambiente de referências políticas e de costumes; mas sim da biografia (claro, ficcionalizada) de personagem reconhecível em nossa história e na sua produção musical. Como diz Michelli, a minissérie pode "dar rosto a personagens históricas".

Um modo de compartilhar informações novas, em processo comunicacional, é construir referências com elementos já reconhecidos entre os interagentes. A minissérie - como muitos romances históricos - faz perceber as questões mostradas, históricas e pessoais da protagonista como vida vivida. Esse ângulo de percepção, todos o temos, por experiência própria: a vida vivida é que permite apreender a singularidade da experiência do outro. Só podemos chegar a uma fusão de horizontes se, de início, temos horizontes pessoais e grupais autopercebidos - que por sua vez desenvolvemos pela comunicação primária em nossos ambientes e grupos de contato direto.

É desse tipo de aprendizagem, então, que se trata. Podemos considerá-la como uma formação de conhecimentos leigos (ou amadores) sobre aqueles aspectos históricos - por contraste ao conhecimento do historiador, do especialista. O conhecimento amador, não especializado, é às vezes injustamente desvalorizado - mas representa, ao contrário, um componente precioso para a agilidade e para a comunicação social. É inegável que pode compor uma formação de cidadão, no sentido de situá-lo em um mundo compartilhado em referências e cultura, mais abrangente que o do horizonte local da existência pessoal. 
A autora explicita, entre as lógicas do caso em estudo, o uso feito do trabalho da memória. A estrutura narrativa aciona esse processo em dois níveis. Por um lado, a história de vida é acionada pela burleta, que a conta; por outro lado, a memória da personagem, ativada pela burleta, se faz reminiscente para fornecer a perspectiva centrada na protagonista, que conta ("revive") sua vida. Com esse fio condutor da memória, os fatos históricos dos contextos referidos ganham um ponto de vista - que é como nós, não especialistas, vemos a história - como também vemos, aliás, a atualidade jornalística. A memória, sendo reconstrutiva, por seu trabalho próprio de gerar sentido, apoia o trabalho de apropriação requerido para ultrapassagem do mero acúmulo de informações, oferecendo articulações de sentido entre estas, tornando-se por isso mesmo viabilizadora de aprendizagem.

Com tais características, podemos assumir que a minissérie apresenta componentes, processos e potencialidades de interação capazes de alimentar uma circulação em que a aprendizagem é componente significativo. Tratando-se de circulação difusa como percurso típico dos produtos massivos, ditos unidirecionais - naturalmente só poderíamos apreender modos específicos de apropriação através de um estudo de recepção, para observar diferentes estratégias de interpretação sobre o programa quando este é articulado com acervos e códigos preferenciais dos espectadores. Compreenderíamos assim fusões variadas que se realizam pela ação do espectador, em sua reflexão e nos trabalhos de memória que ativa em seu entorno pessoal.

Por outro lado, Michelli nos oferece uma evidência da potencialidade de apropriação da minissérie pelo ângulo da aprendizagem. A televisão, apostando em suas expectativas de acolhimento, trabalha ângulos em busca da maximização de tais expectativas. Ao se apropriar da minissérie, o programa Faixa Comentada justamente 
enfatiza o eixo da aprendizagem, concretizando-o em notações de ordem pedagógica. Ou seja: traz componentes, que na narrativa da minissérie são implícitos, para o espaço da explicitação. Aparecem, nessas explicitações, diversos níveis da notação "aprendizagem" que se torna, nesse segundo dispositivo, o eixo principal.

No nível mais difuso, mostra-se o processo de "falar sobre". Um elemento relevante de variadíssimos processos de aprendizagem é a disposição para falar sobre as coisas do mundo - para dialogar sobre ocorrências, situações, objetos; e evidentemente, a respeito dos outros, suas ações, suas posições e ideias; sobre os produtos e processos da cultura. "Falar sobre" é um elemento de aprendizagem porque implica, já, um esforço interpretativo - a expressão é quase um sinônimo de interpretar.

Assim, tomar um produto midiático - no caso, a minissérie - como tema de outro programa, que se organiza como um dispositivo de esquadrinhamento, implica esse movimento de busca de aprendizagens práticas, ao caracterizar, aí, modos de apropriação.

Como modo de falar sobre, agora em nível mais específico, o Faixa Comentada solicita de seus entrevistados comentarem o produto e seus processos de feitura. Isso envolve ativar alguma coisa que vem se desenvolvendo pelo menos desde o século XVII europeu: os saberes da prática ultrapassam o nível do fazer competente, desdobrando-se em uma expressão verbal desse fazer. Os próprios experts procuram expressar e transmitir a experiência prática disseminando conhecimentos que, mesmo não se caracterizando como voltados para formar o especialista, dão a conhecer ao leigo, ao amador, o que fazem os especialistas - estimulando um conhecimento social difuso, viabilizador de interações entre repertórios muito diferentes.

Esse "aprender os processos" de feitura de seriados, com suas decisões, objetivos, expectativas, cálculos de efetividade, busca de 
verossimilhança, de efeitos estéticos, é desdobrado nas falas sobre a própria sustância histórica e sobre as relações entre história e ficção.

A história se articula ao conhecimento dos processos televisuais para uma apropriação leiga pelos espectadores - história para não especialistas. Como Michelli observa, essas referências "trouxeram ao telespectador o realismo da época apresentada pela trama”, fornecendo toda uma variedade de aspectos que compõem a perspectiva histórica do cidadão comum: os dados materiais da cidade, dos prédios e dos transportes; os elementos culturais dos ambientes; aspectos de arte, de política, das relações de família e entre homens e mulheres; a revisitação do abolicionismo - todos, aspectos que só podem ser situados por algum tipo de percepção histórica, por mais simples que seja. É dessa aprendizagem que o texto trata.

As falas são diversas, no Faixa Comentada, e questões variadas são postas - isso parece ser o elemento de saída desse segundo dispositivo do circuito estudado por Michelli. Tais perspectivas variadas circulam já exigindo uma reflexão para dar sentido a sua diversidade. Uma afirmação do capítulo expressa bem o que se coloca como aspecto relevante do fenômeno comunicacional, aqui:

O tipo de aprendizagem gerada e a de entendimento da realidade histórica produzida vão depender da capacidade de edição dos telespectadores e de sua bagagem cultural acumulada. Mas todos podem ir além do mero entretenimento para entrever sentidos históricos nas histórias contadas e nos personagens.

Isso faz lembrar, mais uma vez, que a comunicação não é passagem (de palavras, de informações, de mensagens) de uma pessoa para outrem; mas sim um processo relacional que depende de todos os participantes da interação. Não só no momento do contato e da 
troca - mas em suas expectativas, seus objetivos, seus contextos, seu engajamento nos processos, sua motivação para a repercussão, adiante, do que ali circula. Tanto nas interações imediatas como naquelas, diferidas e difusas, por interposta produção de materiais escritos ou audiovisuais. A interpretação e a apropriação são requisitos interacionais básicos para toda aprendizagem - tanto na televisão como na sala de aula. 


\section{0 fluxo comunicacional de ACERCADACANA}

Paula Reis Melo

\section{Introdução}

Muito tem se debatido sobre o processo de midiatização da sociedade e como isso tem afetado a interação social. Trata-se de um objeto de estudo instigante e complexo, pois estar nesse mundo implica a convivência com os processos midiáticos de modo tão naturalizado quanto o ar que respiramos. Alguém contou: "antes as pessoas chegavam a nossa casa e pediam um copo d'água, agora pedem a senha da internet". Esse processo atinge a todos indistintamente na sociedade globalizada, daí a comparação ao sistema respiratório. $\mathrm{O}$ que isso significa realmente? $\mathrm{O}$ pressuposto implícito é o ser comunicacional, semiótico, simbólico, que é o ser humano.

O segundo pressuposto já foi dito acima: o de que ações de ordem midiática passam a estruturar a interação social. Em outras palavras, os sujeitos agem socialmente em função e a partir do acionamento de possibilidades comunicacionais que se viabilizam por interações midiatizadas. Por isso cabe perguntar: que processo é esse que fundamenta a interação social? Como se dá esse processo? São questões complexas que exigem o se debruçar sobre os fenômenos empíricos.

No estágio atual do conhecimento, ampliar a compreensão desses processos pede estudos de caso, em que se possam observar os diferentes modos segundo os quais se realizam. No 
presente capítulo, será estudada a narrativa do filme documentário ACERCADACANA ${ }^{68}$ e seu transbordamento. O objetivo é reconstruir o fluxo comunicacional através da coleta dos vestígios do seu processo interacional.

O documentário ACERCADACANA ${ }^{69}$, dirigido por Felipe Peres Calheiros, estreou em 2010 em diversos festivais de cinema nacionais e internacionais e a sinopse assim o anuncia: "Nos anos 90, com a valorização do etanol e a expansão do latifúndio canavieiro, 15 mil famílias foram expulsas dos seus sítios na zona da mata de Pernambuco. Maria Francisca decidiu resistir."

Trata-se de um vídeo independente ${ }^{70}$ realizado com recursos do governo de Pernambuco através do Funcultura ${ }^{71}$, da Fundação do Patrimônio Artístico e Histórico de Pernambuco (Fundarpe) e da Secretaria Estadual de Educação. Foi produzido pelo Coletivo Asterisco ${ }^{72}$, um grupo de jovens cineastas situado no Recife que tem se destacado pela produção de documentários (curtas) críticos sobre temáticas diversas. "ACERCADANA" foi selecionado em 28

68 Respeitamos a grafia original do título, escrita com letras maiúsculas e todas juntas.

69 Duração: 19'58”. Ficha Técnica - Produção: Diego Medeiros - Direção: Felipe Peres Calheiros - Roteiro: Felipe Peres Calheiros e Paulo Sano - Fotografia: Felipe Peres Calheiros e Luís Henrique Leal - Som: Nicolau Domingues e Rafael Travassos Montagem: Paulo Sano.

70 Considera-se vídeo independente toda produção audiovisual realizada pelos diversos grupos sociais ou indivíduos que não são sócios ou não estejam subordinados às empresas que detêm concessão pública de radiodifusão. Os vídeos independentes são produtos dos mais variados atores sociais, como ong's; empresas de médio e pequeno porte; movimentos sociais; coletivos de realizadores etc. e podem ou não acessar recursos públicos ou privados para sua realização.

71 Criado em 2003, o Fundo Pernambucano de Incentivo à Cultura (Funcultura) foi implantado pelo Governo Estadual para unificar a distribuição dos recursos financeiros para as ações de produção cultural em Pernambuco. Ver: http://www.fundarpe. pe.gov.br/fomento_funcultura.php

72 http://www.coletivoasterisco.blogspot.com.br/ 
festivais de cinema e mostras nacionais e internacionais, além de ter sido exibido na TV Brasil e de ter recebido prêmios ${ }^{73}$.

Em entrevista à Assessoria de Comunicação (ASCOM) da Universidade Federal de Pernambuco, o diretor Felipe Peres Calheiros afirmou: "Não existe cinema desprovido de posicionamento político. Acredito nesse caminho de envolvimento entre cinema e realidade" ${ }^{\prime 4}$. Assim, o diretor inscreve um "lugar" para o seu filme, e solicita do espectador uma determinada reação, que é no mínimo, ser sensibilizado para a causa em questão.

Trata-se de um documentário participativo, no sentido dado por Bill Nichols de que o diretor se torna um ator social "(quase) como qualquer outro" ao estar numa determinada situação, que se altera pela sua presença e engajamento. "Quase como qualquer outro porque o cineasta guarda para si a câmera e, com ela, um certo nível de poder e controle potenciais sobre os acontecimentos" (Nichols, 2005, p.153-154). Neste encontro entre cineasta e ator social, Nichols pergunta como reagem um ao outro.

Por ser um documentário político-social que apresenta uma defesa de uma causa, a hipótese que se constrói é de que há uma relação colaborativa no processo interacional entre a equipe de produção e a protagonista. E que esta domina a lógica midiática da interação por processo audiovisual.

73 Em 2011 recebeu os seguintes Prêmios: Melhor Curta em 35mm no XV Cine PE; Melhor Filme Curta-Metragem 35mm e Melhor Montagem Curta-Metragem $35 \mathrm{~mm}$ no $43^{\circ}$ Festival de Brasília do Cinema Brasileiro; Melhor Curta-Metragem Latinoamericano pelo $18^{\circ}$ Festival Internacional de Cine de Valdivia, (Chile), e uma Menção Especial do Prêmio Dom Quixote, da Federação Internacional de Cineclubes. Foi exibido no dia 26 de fevereiro de 2012 no Programa Curta TV da TV Brasil.

74 Ver: http://www.ufpe.br/agencia/index.php?option=com_content\&view=article\& $\mathrm{id}=38991$ :filme-acercadacana-de-servidor-da-tvu-e-premiado-no-festival-de-brasilia\&catid $=228 \&$ Itemid $=72$ 
O interesse por esse filme surge devido ao modo de construção de sua narrativa, pelo dispositivo de interação que aciona, sendo um processo de comunicação em ato com cenas articuladas em relação de anterioridade e posterioridade. $\mathrm{O}$ processo de interação, por consequência, torna sua narrativa muito próxima de uma reportagem-denúncia produzindo o efeito de sentido de uma transmissão direta ("ao vivo").

Daí busca-se investigar: que ações e movimentos o documentário executa enquanto processo comunicacional? O que esse grupo de realizadores faz com a câmera e o que a câmera oferece aos realizadores? E o que os demais participantes fazem com a câmera e o que fazem contra a câmera? Considerando a importância do aparato câmera e dos demais elementos em cena e fora dela, como o documentário articula esses elementos de modo a constituir seu processo interacional?

O método de investigação heurística de Braga (capítulo 1) procura compreender como funcionam os dispositivos interacionais. Neste estudo, busca-se observar as ações internas e externas do dispositivo. Por ações internas, entende-se a narrativa do filme propriamente dita, como o filme está construído, de que forma os sujeitos agem na cena interagindo entre si, com a câmera e também contra ela. Procura-se investigar qual é o lugar de fala dos sujeitos e também da câmera, ou seja, o processo de interação entre os participantes da cena; como os usos da câmera interferem e estruturam a ação dos interlocutores que, por sua vez, têm objetivos diferentes.

Por ações externas do dispositivo, entende-se o fluxo comunicacional que o antecede e o sucede, seu contexto e todas as interações que advêm em função do filme. Nessa perspectiva, o filme não deve ser considerado uma fase autônoma em relação ao fluxo comunicacional. Braga ressalta no segundo capítulo que o produto midiático é um "momento particularmente auspicioso da 
circulação", mas há um sistema complexo de relações que o viabilizam. Daí porque interessa investigar "qual a lógica, a regra do jogo que se constata no processo, em seu acionamento social?" (Braga, 2011b, p. 8).

Para se mapear as ações externas do filme como processo comunicacional, são consideradas as relações entre o seu discurso (narrativa) e seu contexto, isto é, o documentário e toda sua circulação: a narrativa; a exibição em festivais e mostras de cinema; a apresentação do diretor nos festivais com a participação da personagem principal, Francisca; as notícias; os prêmios; o blog do coletivo; enfim, a construção de um ambiente de interação no contexto da sociedade midiatizada.

\section{A Narrativa ou as Ações Internas}

Sendo um documentário, além de mostrar o segmento de realidade referido, o filme constrói uma perspectiva sobre a situação; oferece pistas sobre suas próprias posições interpretativas e praxiológicas; e se dispõe a circular pedindo uma determinada leitura e tentando, praxiologicamente, produzir uma incidência nesse entorno no qual, agora, se inclui. A narrativa é construída de modo a fazer uma denúncia social e esse apelo é reiterado a todo momento através de diversas estratégias, como se verá.

O filme é composto por depoimentos colhidos com a realização de entrevistas, pelas imagens do lugar (canavial e sítio de Francisca), por cenas "de interação em ato", como "testemunha" e cenas do tipo "flagrante". Pela sua dimensão temporal, apresenta uma estrutura textual predominantemente narrativa devido a uma relação de anterioridade e posterioridade em relação às ações dos participantes.

Quatro momentos do filme devem ser destacados como relações que viabilizam o fluxo comunicacional. O primeiro é a cena de 
abertura; o segundo é a visita ao sítio de Francisca para se conhecer o cotidiano; o terceiro é a cena "testemunho"; e o quarto é o flagrante da queima do canavial. Em cada um destes momentos, é atribuída à câmera uma função específica, por diferentes agentes, fazendo-a ocupar um determinado lugar de fala no processo de interação, como será desenvolvido a seguir.

\section{Cena de abertura}

O ponto de partida do filme é a apresentação da história da agricultora Francisca, através do depoimento de um homem que aparece em primeiro plano sentado no banco do motorista de um carro e se apresenta como advogado da Comissão Pastoral da Terra ${ }^{75}$ (CPT). Ele contextualiza a situação dos agricultores moradores das terras da Usina Petribu que são pressionados a aceitar uma indenização irrisória para deixar o local, ao que Francisca decidiu resistir. Daí estar sofrendo ameaças.

$\mathrm{O}$ advogado conta que a CPT tomou conhecimento do caso porque ela denunciou a situação no programa de rádio de Cardinot $^{76}$ que, por sua vez a encaminhou para a OAB, Seção Pernambuco. Ao ir à sede da $\mathrm{OAB}$, um padre membro da $\mathrm{CPT}$, decidiu que a entidade daria assistência jurídica à moradora do engenho.

Nesta cena de abertura, vê-se a interação em ato, com a câmera sendo guiada pelo advogado. Este é o guia tanto do conteúdo, porque é ele quem relata a denúncia de ameaça que a agricultora sofre do Grupo Petribu, quanto da logística, pois está sentado ao volante

75 A Comissão Pastoral da Terra é uma entidade ecumênica que dá assessoria jurídica e política a movimentos sociais que reivindicam a reforma agrária.

76 Apresentador de programa de rádio e de televisão na linha policial, que recebe denúncias de todo tipo de crime e cobra providências à polícia e às "autoridades competentes”. Atualmente Cardinot só mantém o programa televisivo. 
do carro para levar a equipe de filmagem à casa de Francisca. De repente, o advogado, olha pelo retrovisor, ouve o barulho de um carro se aproximando, interrompe o seu relato e anuncia:

- Os caras da Globo!, diz o advogado se dirigindo à equipe de filmagem.

- Daniel?, diz o produtor da Globo de dentro do carro da reportagem.

- Isso. Tudo bem? Como vai? A gente está indo lá para o sítio dela. O pessoal está fazendo um filme da história dela e tal. E aí também queriam filmar. Vocês também ficaram interessados na história dela?, pergunta o advogado para o produtor da Globo.

- Sim, onde é que fica?, pergunta o produtor da Globo.

- É entrando aqui. Vocês encostam aqui, a gente faz a volta e vocês vão atrás de mim, informa o advogado.

- Depois a gente continua, né? Diz o advogado para a equipe de produção do filme, depois de ligar o carro e iniciar a manobra.

- Sim. Responde alguém da produção do filme.

Toda essa cena de abertura é mostrada com o enquadramento do advogado em primeiro plano em um plano-sequência até fade -out (passagem a escuro total), o que reforça a interação em ato, pois não houve corte. Há uma correspondência entre o tempo da interação dos participantes e a duração da cena no filme. Este trecho constrói um efeito de realidade da denúncia: o advogado vai guiar a visita das duas equipes de produção ao sítio de Francisca, a do filme ACERCADACANA e a da TV Globo; e gera uma expectativa e até uma tensão do que poderá ser encontrado. 
Nesta cena, a interação se dá em torno de uma promessa. Deduz-se que houve uma interação anterior ao filme acionada pelos interagentes em vista do fluxo midiático previsto: houve um contato prévio da equipe de produção do filme para marcar o lugar do encontro, assim também com a equipe da TV Globo. O que seria considerado "bastidores" se torna "palco". Ao manter no filme a cena da chegada da equipe de reportagem da TV Globo ao local, o documentário ressalta a importância desse recorte da realidade, vez que o interesse jornalístico da TV Globo é referência na sociedade midiatizada. O efeito é de reforço da importância do caso e consequentemente do próprio documentário como produto fílmico. Neste momento, o diretor faz do interesse da TV Globo importante aliado para dar a dimensão do caso.

Ainda nesta cena, há a imbricação do campo midiático com o campo jurídico. Como dito anteriormente, foi através da denúncia num programa de rádio que Francisca chegou à sede da $\mathrm{OAB}$ e teve a coincidência de encontrar um padre da $\mathrm{CPT}$ que se interessou pelo seu caso. $\mathrm{O}$ jurídico foi acionado a partir do campo midiático.

O olhar da câmera como lugar de ocorrência de tensões e de conjugação de um sentido vai se intensificar no próximo momento de visita ao sítio de Francisca.

\section{Visita ao Sítio de Francisca}

A cena que segue após a abertura é a seguinte: fade-in (passagem de escuro à cena), aparecendo a imagem da monocultura da cana-de-açúcar, com o ruído do vento nas folhas do canavial, fazendo o efeito de uma passagem de tempo simbólica. Aparece então a seguinte legenda: "Engenho Tiúma - São Lourenço da Mata-PE - Brasil”. Agora já é outro dia e apenas a equipe do documentário chega para uma visita. Um dos produtores relembra que 
membros da equipe estiveram lá antes, no mesmo dia que a equipe da TV Globo. Dona Francisca critica: "Só que não passou nada, já viste? Parece que os homens da Globo estão com medo, né?”.

Com esta fala de Francisca remetendo à ausência de transmissão da reportagem pela TV Globo, o documentário se distingue dela. Diferentemente da referência à TV Globo na cena de abertura, agora não a trata mais como aliada no interesse sobre o caso de Francisca. Neste momento, o diretor demarca seu posicionamento político contra-hegemônico e gera, instantaneamente, uma tensão no mercado discursivo. $\mathrm{O}$ documentário se apresenta claramente como outra alternativa de informação e alerta o futuro espectador de que ele não receberia essa informação via TV Globo. Novamente, os bastidores se tornam palco, mas dessa vez, para fazer uma crítica à mídia hegemônica.

Diferentemente da primeira cena, neste trecho há uma edição de imagens alternadas com a câmera na mão, mostrando Francisca que "apresenta" sua casa, sua família e seu cotidiano, numa interação direta com a câmera, e com imagens produzidas com a câmera parada (no tripé) num lugar de "contemplação".

Ao receber nova visita da equipe de produção, Francisca interage com o espectador futuro do documentário demonstrando saber usar a câmera. Esta deixa de ser uma "personagem" estranha com a qual teria um receio de como se relacionar, e passa a ser objeto de uma ação interacional da personagem Francisca. Neste momento, ela "aproveita" para denunciar à equipe, que está com a câmera ligada, a pressão que os agricultores sofreram para sair das terras e que somente ela ficou no lugar, por isso vive recebendo ameaça.

Contextualizando o cotidiano, aparecem imagens com cenas do dia-a-dia dos membros da família: o pai levando (ou trazendo) as crianças de bicicleta para a escola; meninas lavando roupa no açude; um velho sentado embaixo de uma árvore enquanto vê um 
menino brincar no balanço pendurado nessa mesma árvore. Estas "fotografias contemplativas" são intercaladas com também imagens paradas do canavial, num grande plano geral que mostra a imensidão do canavial com o caminhão em plena produção, carregado.

Essa montagem produz o efeito de realidade da denúncia de desigualdade social: o contraste entre a imensidão e o poderio do canavial com as condições da casa, feita de taipa, fogão à lenha, panelas queimadas pelo fogo; e o tamanho da propriedade. Há uma tomada definitiva desta comparação: no meio do imenso canavial, vê-se um grupo de árvores; a objetiva se aproxima e aparece a casa de taipa de Francisca. Ela mora ali, cercada pelo canavial que ameaça tomar o espaço de seu sítio.

$\mathrm{O}$ uso feito da câmera, aqui, cumpre a promessa: a denúncia ganha concretude e a interação segue mais intensa a partir do terceiro momento.

\section{Cena Testemunho}

O terceiro momento é o auge da tensão e o que mais se parece com uma transmissão direta ("ao vivo") porque além de haver uma correspondência entre a duração da filmagem e do acontecimento, parece ter sido inesperado, o que dá mais intensidade ao efeito de realidade. As imagens mostram Francisca apontando de dentro da sua casa, pela janela, a sua plantação de macaxeira (aipim) quando ela ouve uma voz ao longe e os cachorros latem anunciando a vinda de alguém. Francisca interrompe o que estava dizendo, e anuncia: "olha, o vigia, o vigia da Petribu!" e vai saindo de dentro de casa seguida pela câmera, criando uma tensão, e enquanto caminha até chegar à frente da casa e avistar o vigilante, a tensão vai aumentando.

Quando ela chega à área externa, avista o vigilante fardado que diz: "Passaram um rádio para a gente dizendo que tinha um carro 
roubado aqui". Francisca vai ao encontro dele, e responde: "Não, é conhecido aqui, olhe", sempre com a câmera atrás dela. $\mathrm{O}$ vigilante responde: "Está certo." Ela anda até perto dele e diz "venha cá", e ele: "está bom", fazendo um sinal de "jóia" com a mão e vai se retirando ao perceber que ela continua interpelando-o e que tem, por trás, uma câmera. Ele percebeu neste momento que está sendo filmado. Ela insiste e tenta interagir com ele incluindo-o na cena e diz: "venha cá! Esse aqui nunca me fez mal não. Este aqui trabalha de vigia, de segurança, não é, sr...?”, ele está enquadrado de frente para a câmera e ela, de costas para a câmera. Aqui Francisca mostra a habilidade em fazer uso da câmera, como se estivesse dirigindo a cena e comandando sua tomada. $\mathrm{O}$ vigilante diz que vai embora e começa a correr, fugindo da situação. Ele se nega a interagir com Francisca sob o olhar da câmera, ou seja, segundo a lógica acionada por ela para mostrá-lo ao mundo, mas, afinal participando, pela própria tentativa de recusa e rompimento. Francisca corre atrás dele gritando: "o senhor é vigia da Petribu, mas o senhor nunca me fez nada de mal não!”.

O dispositivo funciona como se Francisca estivesse "armada", só que com a "arma" da imagem-testemunho. A câmera segue Francisca, que corre dizendo: "O senhor vai correndo, é, Seu Zé? Não tenha medo não!”. O vigilante corre pela linha do trem e some atrás do canavial. Francisca aponta uma caminhonete que chega nesse momento e ouve-se uma voz em off de algum membro da produção do filme: "tem um carro vindo aí". A tensão cresce. Aparece um homem de camisa listrada para proibir a filmagem. Francisca diz que é área pública do trem e aproveita a oportunidade para fazer a denúncia que recebeu ameaças para deixar a terra. E pede o apoio da imagem: "você tem ou não tem o retrato que tirei aqui, os caras armados de revólver?”. 
Cada sujeito age de acordo com a estrutura do dispositivo interacional, desencadeando todo um processo de interação social regido pela disputa de sentido em torno do real.

Essa cena real aconteceu em função dos usos feitos da câmera na casa de Francisca e, além de produzir um efeito de "ao vivo", produz um efeito de autenticidade (Fechine, 2006, p. 146) da denúncia em questão ("de fato, isso acontece: a família encontra-se totalmente vigiada"). É uma cena antológica da sociedade em midiatização: trata-se de uma denúncia contundente porque o código, neste caso, é outro. A correlação de forças se coloca não pela violência brutal, mas pela dimensão simbólica.

O filme termina com o quarto momento em que a câmera faz um flagrante, como se explica a seguir.

\section{Flagrante da queima do canavial}

O quarto momento é a cena "flagrante" do incêndio no canavial à noite. As imagens contextualizam: o canavial no escuro; na casa, luz de candeeiro a querosene, fogão a lenha. Aparece a seguinte legenda no fundo preto: "Desde 2004, Maria Francisca luta na justiça pela posse de meio hectare de terra onde mora há mais de 40 anos. O grupo Petribu possui 28 mil hectares de terra e fabrica 120 milhões de litros de etanol por ano". Seguida de outra: "Imagens gravadas por Elisângela, filha de Maria Francisca, durante o corte da cana de 2010". As imagens mostram o canavial ardendo em chamas bem perto da casa e ameaçando destruir a roça. Francisca aparece em primeiro plano com o fogo no canavial ao fundo, e aponta para o plantio de subsistência dela: "se queimar, eu estou filmando [...] se uma labareda de fogo saltar, pega na minha casa”.

O fato das imagens terem sido produzidas pela filha de Francisca demonstra a intensificação do processo de midiatização 
da sociedade, em que as lógicas midiáticas internalizadas pelos atores sociais acionam interações experimentais. $\mathrm{O}$ modo como este documentário foi produzido apresenta outra relação interacional porque são os próprios personagens que geram imagem. Isto dá, ao mesmo tempo, um alcance à cena talvez jamais conseguido se dependesse da presença do realizador. $\mathrm{O}$ filme, enquanto produto, se torna devedor dessa cena para se mostrar.

A presença da câmera neste caso produz um efeito de sentido de vigilância que é o sentimento de prontidão (Fechine, 2006, p. 149) para "flagrar" e materializar a denúncia, além do efeito de protagonismo de Francisca e família. $O$ fato de a câmera ser conduzida pela filha Elisângela tende a realçar, para o espectador, a não mediação do documentário enquanto filme. Entretanto, revela-se com isso, a midiatização do processo comunicacional, tanto pelo acionamento de outro sistema de interações no próprio filme, como pelas pretensões do filme em relação a interações com o espectador.

Desses quatro momentos, depreende-se que o fluxo do documentário enquanto discurso se processa em ato vinculando-se a momentos anteriores e posteriores. Primeiro, tem-se uma relação com outro programa de rádio, num processo de midiatização em curso. É, já, uma repercussão, pois um grupo de realizadores se interessa pelo assunto. $\mathrm{O}$ acionamento do dispositivo interacional, com o efeito de sentido de promessa, revela o que ficaria nos "bastidores" da produção midiática com o encontro marcado com a equipe de produção do filme e com a equipe de reportagem da TV Globo.

No segundo momento, a denúncia ganha concretude pela confirmação da situação de opressão e pela estratégia de comparação entre a imensidão do canavial e a "pequenez" do sítio de Francisca.

No terceiro momento, a cena testemunho gera o efeito de autenticidade decorrente da cena "real" provocada pela visita da equipe de produção à casa de Francisca. De fato, Francisca está 
sendo vigiada constantemente, pois o vigilante aparece com a desculpa de que haveria um carro roubado.

E, finalmente, no quarto momento, a narrativa é construída com as imagens do tipo "flagrante" produzidas pela filha de Francisca. Esta faz denúncias de modo contundente, cuja interação no âmbito do dispositivo demonstra os efeitos de vigilância e de segurança por estar munida de uma câmera.

Esses momentos são construídos pela produção do documentário, o que confere à câmera a possibilidade de ser acionada como elemento chave do dispositivo. É por seu uso específico, mostrado, que são geradas ações dos participantes do filme, mas não simplesmente por estar presente e sim por ser bem articulada no ambiente próprio de interação. Uns estão contra esse uso e outros a favor.

Assim, confirma-se a hipótese de que há uma relação colaborativa no processo interacional entre a equipe de produção e a protagonista. E que esta domina a lógica midiática da interação via processo audiovisual.

Considera-se que o dispositivo de interação do documentário não se encerra ao final da audiência do filme, uma vez que cria outras relações, consolidando os circuitos comunicacionais. Ao estrear no festival de cinema Cine PE em 2001, e chamado ao palco para apresentar o filme, o diretor Felipe Calheiros convidou não somente a equipe técnica de produção, mas também Francisca e familiares. Ao fazer uso da palavra, Francisca reforçou toda a denúncia que soou mais viva e produziu um efeito de autenticidade do documentário. Ela foi a testemunha de que o filme era "real". Como num processo infinito de semiose, agora era a pessoa real que dava o testemunho de autenticidade do filme.

A descrição acima é uma tentativa de identificar as ações internas postas em prática pelo dispositivo interacional do documentário 
"ACERCADACANA". Investigar as ações externas irá contribuir para a compreensão de seu processo interacional.

\section{0 Transbordamento da Narrativa}

Uma primeira ação do filme é a estratégia de sensibilizar para a questão em tela. O próprio título "ACERCADACANA", escrito com todas as letras juntas e em caixa alta, traz implícita uma ambiguidade: A Cerca da Cana e Acerca da Cana, ambas as leituras remetem a mais de um sentido.

A leitura "A Cerca da Cana" remete a um sentido figurativo/ metafórico, de que existe uma "cerca", um interdito, em torno do tema cana-de-açúcar. Já a leitura "Acerca da Cana" pode remeter a um sentido mais direto, até literal, de que vai se falar a respeito do problema técnico da cana-de-açúcar. Essa estratégia busca captar o interesse do espectador. Não há interação sem relação interessada, não importam as razões ou os motivos. $O$ documentário utiliza uma narrativa que gera tensão como forma de capturar o espectador.

Um segundo movimento implica uma estratégia de demonstrar autenticidade e, assim, conquistar a confiança ou credibilidade de que o que é dito é verdadeiro. Como se viu, há o efeito de autenticidade produzido nas cenas "reais" e "flagrantes" (que também são "reais").

Uma terceira ação do dispositivo é de ordem pragmática. O documentário visa uma mudança do estado de coisas. Expõe as desigualdades do capitalismo com imagens das condições de vida da família de Francisca através do método da observação fazendo uma descrição (em imagens): as panelas de alumínio amassadas cozinhando no fogão a lenha; detalhes de mãos espremendo a roupa lavada na beira de um rio; a casa de taipa. Tudo isso se contrapõe à força da indústria do etanol: imagens do canavial a perder de 
vista, paisagem sem variação; as máquinas de colheita; os vigilantes fardados.

O movimento pela mudança do estado de coisas se materializa em diversas outras ações, como respostas críticas do próprio diretor à imprensa (referidas no início do texto); exibição do filme nos espaços mais variados; divulgação dos prêmios e de notícias sobre a repercussão do filme no blog do Coletivo Asterisco; venda de exemplares do documentário para arrecadar fundos para reformar a casa de Francisca. Diversos circuitos são desenvolvidos no acionamento do processo interacional do filme.

Estas descrições, análises e reflexões expressam as lógicas interacionais que direcionam a elaboração do documentário, assim como sua inscrição, correlata, no fluxo comunicacional - como forma e processo de fazer política do Coletivo Asterisco.

Nota: Francisca construiu, no sítio onde mora, uma casa de alvenaria com o dinheiro arrecadado com a venda dos DVDs. Ao mesmo tempo, a Justiça deu ganho de causa à Usina Petribu. A ação de despejo não ocorreu porque os advogados dela recorreram da decisão, estando o caso sub judice. 


\title{
Suíte n ${ }^{0} 4$
}

\section{“0 fluxo comunicacional de ACERCADACANA", de Paula Melo}

\author{
José Luiz Braga
}

O que Paula observa não é apenas o produto filme ou o meio cinema. O capítulo estuda um processo geral cujas lógicas caracterizam um episódio interacional: a feitura do filme, como conjunto de interações requeridas entre seus diferentes participantes para a geração do produto e para seu encaminhamento a determinados circuitos. A partir de indícios no filme, com ou sem informações adicionais, é sempre possível reconstituir, em alguma medida, elementos do processo comunicacional singular que o gerou.

Podemos nomear o dispositivo estudado por Paula Melo a partir da ação comunicacional de "fazer filmes documentários". Podemos cercar o dispositivo com maior precisão: "fazer filme documentário de denúncia social". O filme em pauta é um resultado do acionamento desse dispositivo geral, com tudo o que o caracteriza: - o componente câmera, é claro; e também todos os demais componentes habituais: direção, cenografia, planejamento e roteiro, depoentes ou protagonistas das cenas colhidas, gente em cena, iluminação, sonoplastia, tensões e colaborações na equipe, obtenção de recursos e financiamentos... É na lógica desse dispositivo que o filme vai recortar sua especificidade. Os participantes vão se organizar em episódios singulares que redesenham o dispositivo para sua elaboração própria. $\mathrm{O}$ sistema de relações estabelecido na prática da produção se mostra ou se esconde na materialidade do produto finalizado. 
A fala, o discurso, os materiais de sentido, os dispositivos em geral que a prática social constrói (e disponibiliza) - tudo isso busca estrutura. Se esta é sempre tentativa (e não apriorística, mas sim gerada na variação da prática), é porque pode "dar certo" em diferentes graus; e pode eventualmente, contra expectativas que inicialmente movem a tentativa, resultar em fracasso. Conforme o grau de eficácia, alguma reiteração de bons resultados e a possibilidade de transferência para outras situações, a estrutura se desenha, se estabelece - e se torna disponível para outros acionamentos, agora menos experimentais e tentativos: com expectativas lastreadas nos resultados anteriores.

O que uma investigação sobre os processos comunicacionais busca é perceber como esse produto singular elabora suas especificidades, dentro das características abrangentes do dispositivo referido. Essa articulação se mostra (através de indícios presentes no filme) com o sistema de regularidades adotado (e construído) pela equipe de produção, nas condições concretas da situação abordada.

Uma das características interessantes do filme observado é que, longe de disfarçar o processo de interação que está em sua base, pode ser visto praticamente como um exercício de mostrar-se a si mesmo em sua feitura. É a cena que comanda em boa parte a filmagem. Cada participante interage segundo sua iniciativa; mas os diferentes gestos se articulam, com felicidade de resultados. O trabalho de edição, por sua vez, faz compor adequadamente, com os materiais assim tornados disponíveis, um conjunto bem estruturado. Pode-se pensar que o resultado depende demais da casualidade, e da personalidade, rara, da protagonista Francisca, que assume em determinado momento a condução das interações. Mas é possível, também, perceber que, suspensos alguns padrões mais canônicos (dispositivos interacionais muito fechados em suas 
próprias regras), as estratégias dos participantes adquirem certa probabilidade de oferecer experiências intrigantes.

Outra característica específica é que esse grau de liberdade aceito e procurado pela equipe criadora do filme faz sintonia com a posição adotada perante a situação polêmica mostrada como tema. Seu processo comunicacional aberto, na feitura, serve mais aos objetivos daquela posição do que eventuais discursos argumentativos. $\mathrm{O}$ gesto, a palavra, o argumento e o se mostrar dinamicamente em ação se evidenciam como comunicação: dão a característica central do episódio que realiza, com especificidade, o dispositivo escolhido; e ao mesmo tempo, dão lastro à posição de reivindicação contra a rigidez opressora.

Ao referir a construção das cenas mostradas no filme, Paula Melo toma a câmera como pivô do processo - o que é pertinente, uma vez que, no produto, o que nos chega, aos espectadores, é o que o aparato capturou (e depois, foi selecionado pela edição). $\mathrm{Na}$ cena, ao ocorrerem as interações entre os participantes, estes não agem apenas entre si, mas o fazem também para a câmera, e eventualmente com ela.

Ao mesmo tempo, a câmera não é um ponto fixo e neutro no espaço, em torno do qual os participantes executariam seu bailado interacional. A própria câmera (na mão de seu operador) é acionada de diferentes modos por vários participantes - é feita agir por estes. Não só o diretor comanda sua ação. O intérprete ou depoente, que se locomove, com maior ou menor velocidade, em percurso direto ou errante, faz a câmera acompanhá-lo. Quem é olhado também dirige o foco. Ou, como diz o texto, é possível interagir "contra" a câmera.

Nesse jogo interacional entre os participantes (personagens e equipe cinematográfica) é que se manifesta o específico - o caso dentro da situação geral ("Maria Francisca resolveu resistir"). A 
filmagem se explicita como interação para fazer o produto, mas também como interação política sobre a situação.

Assim, a especificidade ultrapassa o discurso sobre a situação para chegar ao processo interacional do "fazer filme". Em alguns momentos, a protagonista literalmente dirige a cena e a ação comunicacional. Primeiro, por seu deslocamento físico; em seguida dando a marcação gestual e verbal para o trabalho da câmera. Uma ação interacional direta faz desenvolver o episódio - tanto no processo de diálogo como no da produção do filme. A afirmação de que a protagonista "domina a lógica mediática" não leva à ideia frequente de que conhecer as regras significa se submeter a elas (funcionar dentro delas). Bem diversamente, corresponde a saber interagir com essas lógicas - no caso, segundo os padrões da própria protagonista, que tenta e consegue redirecioná-las conforme seus objetivos.

Aparece aí um ponto alto do dispositivo de feitura do filme: a personagem em cena dirige o olhar da câmera - primeiro se locomovendo livremente no cenário, passando sem previsão do ambiente da casa para o ambiente externo, fazendo incluir na cena um participante não previsto, que se aproxima - funcionário da empresa que pressiona os pequenos moradores. $\mathrm{O}$ gesto "obriga" a câmera a acompanhar o movimento. A protagonista passa a dirigir explicitamente a câmera, a cena e outros participantes. A sabedoria do diretor é a de aceder a essa direção.

O que me parece central, no episódio, é - dentro do dispositivo "fazer filme documentário de denúncia social" - a flexibilidade deste, tão logo os participantes da interação (incluindo, é claro, o diretor) se entregam à realização da cena em gesto diretamente comunicacional - entre os participantes, no "ao vivo" da ocorrência; mas também mantendo o processo fílmico em atividade, para levar, quase cruamente, essa interação ao passo subsequente, que ocorre por mediação interposta, do filme junto a seus espectadores. 
O nível experimental do processo se manifesta também por uma inclusão de filmagens feitas pelos depoentes - que então aparecem não mais só por sua própria imagem mostrada e por sua voz; mas ainda no processo direto de feitura dos materiais inclusos no produto.

Uma relação básica do caso em pauta com os conceitos que formam o eixo deste livro é a percepção do "transbordamento" da narrativa do filme, conforme observa Paula - que corresponde justamente à entrada das interações e seus resultados em circuitos pertinentes ao tipo de produto e ao tipo de objetivos com que este foi produzido. Como propõe a autora, é possível "reconstruir o fluxo comunicacional através da coleta [no próprio produto observado] dos vestígios de seu processo interacional”.

Uma ação comunicacional através da ordem midiática implica geralmente um desdobramento. Há uma ação na feitura do produto, que nele deixa sua marca, com maiores ou menores decisões seletivas. Seguem-se ações de interação a distância, de que o produto se faz portador junto a seus usuários; assinalando que o uso, aqui, é um tensionamento comunicacional - interpretativo, fruidor ou crítico.

Evidentemente, esses dois níveis produzem incidências mútuas. O primeiro sobre o segundo, por sua solicitação de leitura direcionada; o segundo sobre o primeiro, na forma das expectativas relacionadas ao olhar interpretador pretendido.

Transbordamento é uma boa expressão para evidenciar o extravasamento comunicacional de um episódio (e do dispositivo aí acionado e especificado) para uma circulação que se amplia, do círculo restrito dos participantes diretos, para outros circuitos. 
Por isso mesmo, nos interessa a circulação mais ampla que a percorrida diretamente pelo filme-produto. A circulação do produto entre a emissão e a recepção é apenas uma parte de um fluxo mais extenso. Vem desde a situação que desencadeia seus próprios processos interacionais - políticos, sociais, culturais. Em algum ponto das interações de embate, surgem o interesse e a relevância de ver isso abordado por um olhar cinematográfico, para fazer seguir adiante a situação - para oferecer uma interpretação desta como estimulação para outras e outras interações. Dentre as quais, é lógico, a de chegar a espectadores que produzam e façam circular sobre o filme suas próprias impressões e interpretações - no caso, com a expectativa de reforçar a causa que o filme defende.

$\mathrm{O}$ filme (mais exatamente: o dispositivo interacional que o elabora) se explicita como ponto nodal naqueles circuitos não só pelo tema tratado, mas também pela explicitação, no próprio registro, das interações que o produziram. Volta-se para os circuitos em que a própria situação político-social pode se inscrever - o conflito político, com sua carga de opressão, o processo jurídico que encaminha a relação de poder, os circuitos midiáticos alternativos, a eventualidade dos circuitos hegemônicos. A força do episódio se manifesta no modo de mostrar o tema, na ênfase em explicitar a própria feitura do produto; e no gesto de seu encaminhamento para circuitos nos quais a polêmica social se desenvolve.

Por outro lado, o circuito jurídico, até o momento em que a autora acompanha a questão e nos informa (ver nota final do capítulo), se mostra impermeável à substância do que o filme mostra e defende. Aparentemente, nesse circuito, marcado por cânones rígidos ou por incidências político-econômicas, o filme não conseguiu ingressar em modo pregnante. 


\section{TV \& Comunidades: um dispositivo em construção}

Rosana Cabral Zucolo

\section{Introdução}

Este capítulo aborda a experiência de interação entre um canal de televisão - o Canal Futura (CF) - e entidades de ação comunitária - a Oficina de Vídeo do Oeste; e o Grupo Ecológico Guardiões da Vida ${ }^{77}$. Estudamos a constituição de um dispositivo interacional num cenário em que as estratégias e operações desenvolvidas de parte a parte na implementação de atividades em conjunto reconfiguram, de modo tentativo, tanto as práticas comunitárias como as midiáticas, gerando mudanças nas condições de produção de comunicação e na própria ação comunicativa.

Buscamos delinear as lógicas em interação com base no percurso das operações desencadeadas tanto na e pela instância midiática, quanto na e pela instância comunitária. Planejamento, circulação, recepção, formação, produção, monitoramento integram tais processos na instância comunitária e na instância midiática, bem como as percepções de parte a parte e os resultados obtidos. $\mathrm{O}$ objetivo é o de observar, na prática dos diferentes agentes:

77 A pesquisa em que se baseia o presente capítulo foi desenvolvida em minha pesquisa de tese de doutoramento, na Unisinos (Zucolo, 2014). 
a. como funcionam e se afetam mutuamente as diferentes lógicas - midiáticas e comunitárias;

b. o que geraram enquanto ações comunicativas e de inovação social.

Desenvolvemos a reflexão a partir da observação das interações e dos processos reguladores de situações de comunicação que ocorrem entre os diferentes agentes, uma vez que o objeto passa a incluir tanto a mídia quanto os receptores e suas mediações em formações múltiplas - enfocando as relações que tais processos organizam na sua singularidade.

Procuramos evitar a visão unilateral e restritiva da mídia enquanto instauradora e controladora dos processos comunicacionais. A perspectiva interacional, conforme aqui é entendida, evidencia uma continuidade entre os processos comunicacionais desencadeados pela mídia e aqueles distantes do midiatizado e que estão inscritos no fluxo comunicacional em outros âmbitos da sociedade (Braga, 2012b). É a este conjunto inter-relacionado que caracterizamos como processo de midiatização da sociedade. Estamos diante de um sistema de relações operando entre os distintos componentes do processo. Estes se articulam com base em padrões já existentes, mas vão além desses padrões para que a interação ocorra. As práticas sociais se organizam em dispositivos variados que de algum modo modelam o comunicacional que aí ocorre. E os dispositivos interacionais, tal como propõe Braga (capítulo 1) são produzidos pelos próprios episódios interacionais que acionam as suas matrizes para interagir, e ao mesmo tempo, são modulados pelos contextos e processos institucionais específicos em cujo ambiente se desenvolvem.

A pesquisa que deu origem a este capítulo se situa num contexto que corresponde a dinâmicas muito amplas, a partir da inscrição de seu objeto na perspectiva dos estudos da midiatização. Para fazer inferências sobre essas dinâmicas observamos, no 
contexto caracterizado pelo perfil dos dois conjuntos de agentes, os processos que demarcaram a constituição de vínculos e as apropriações no espaço de negociação entre a produção, a oferta, a recepção e a circulação de um dos principais projetos em que a interação dos parceiros vem se realizando: o Projeto Maleta Futura.

Estudamos as lógicas interacionais que marcam a implementação do projeto Maleta Futura, como ação de mobilização comunitária junto à Oficina de Vídeo Oeste (TV OVO) e ao Grupo Ecológico Guardiões da Vida (GEGV), duas ONGs gaúchas de forte atuação no social, sediadas nas cidades de Santa Maria e Passo Fundo, respectivamente.

Explicitaremos a gênese do Projeto Maleta, suas características, e os modos de operação do canal em vista da sua implementação. Observaremos ainda os processos que envolvem a implementação das maletas temáticas produzidas pelo Canal Futura e seu uso e análise no âmbito dos grupos comunitários, pontuando suas operacionalidades, ações e dinâmicas desencadeadas pelos participantes. Concentraremos a observação nas dinâmicas do grupo comunitário TV OVO com as maletas Toda Beleza e Democracia; e do grupo comunitário GEGV com a maleta Meio Ambiente.

\section{A instância midiática e a instância comunitária na base do dispositivo interacional}

\section{Canal Futura}

O Canal Futura integra as Organizações Globo como projeto da Fundação Roberto Marinho (FRM). Ele se enuncia enquanto "um canal privado de interesse público, dedicado à educação", com "o compromisso social de ampliar as possibilidades de mobilização e participação das camadas D e E, para as quais dirige preferencialmente a sua programação" (Canal Futura, 2010). Desenvolve-se a 
partir de um modelo peculiar de sustentabilidade - apoiado em parcerias com a iniciativa privada, situadas em relação a ele enquanto mantenedoras da programação e das ações sociais de mobilização. $\mathrm{O}$ canal é apresentado como "resultado da parceria entre organizações da iniciativa privada, líderes nos seus segmentos [...] conscientes da importância de participar ativamente na transformação da realidade social e $[. .$.$] , consolidar a imagem de uma empresa cidadã" (CF).$

O Canal Futura afirma os objetivos de romper com o modelo televisivo generalista, consolidado historicamente com base em uma lógica de organização apoiada na transmissão em fluxo da programação; e de alterar as mediações televisivas, mais habitualmente pensadas como ponto de articulação entre um sistema centralizado de produção e um sistema de recepção difusa.

Com tais perspectivas, o CF opera em espaços tradicionalmente não televisivos através de uma instância mediadora, a Articulação e Mobilização Comunitária, e atua junto aos grupos de ação comunitária e de movimentos sociais, de onde emanam sugestões/produções de conteúdos para o canal, alterando também a relação entre produtor/usuário.

Ao instituir essa instância mediadora - o setor de Articulação e Mobilização Comunitária - para, através dela, operar diretamente no espaço social, apropria-se de uma dinâmica de outro campo que não o televisual, interagindo com ele de forma bastante experimental e buscando estabelecer outros circuitos e modos de circulação de seus produtos seriais, como veremos adiante.

\section{Os grupos comunitários}

Os grupos comunitários são caracterizados pelas ações coletivas de interesse comum que marcam os cenários da vida cotidiana através de vínculos e laços de natureza diversificada. Existindo em um espaço de relações sociais mais próximas e coloquiais, os 
processos comunitários são permeados, habitualmente, por conhecimentos do senso comum, organizados em procedimentos que se caracterizam por esquemas de operações e manipulações técnicas capazes de assegurar o seu funcionamento (Certeau, 2012).

Tais conhecimentos de senso comum são organizadores e, em dadas ocasiões, assumem um caráter social, consensual e mobilizador. São também caracterizados pelo imediatismo espacial e temporal, trazendo as marcas da oralidade e da conversação que se constitui em espaço essencial da comunidade (Certeau, 2011). Naturalmente, para observarmos grupos comunitários contemporâneos, é preciso levar em consideração as profundas mudanças que o modo de viver em sociedade e em agrupamentos humanos tem enfrentado (Bauman, 2003).

O Grupo Ecológico Guardiões da Vida (GEGV) é uma ONG, fundada em 1999, na cidade de Passo Fundo ${ }^{78}$, RS, que através do trabalho de voluntários e estagiários, se volta à problemática ambiental no município e na região. Tem forte atuação local, regional e nacional, através da participação em fóruns e mobilizações em instâncias decisórias das temáticas ambientais como a Comissão de Políticas de Desenvolvimento Sustentável (CPDS) e a Agenda 21 Nacional. Desde 2005 tem uma parceria estabelecida com o Canal Futura, ano em que a ONG, a Embrapa, a Coordenadoria Estadual de Educação e o CF promoveram uma ação em um projeto de implantação de hortas comunitárias em setes escolas públicas na região da cidade de Passo Fundo, denominado 'Semeando o Caminho para o Futuro $^{39}$. O Canal Futura fazia a cobertura jornalística, registrando a atividade de cada escola e a ação da comunidade.

78 A sede do grupo fica na Rua Teixeira Soares, ${ }^{\circ} 625$, no centro da cidade de Passo Fundo, no RS.

79 Apontado também pelos mobilizadores do Canal Futura como um dos projetos de melhores resultados, ele foi suspenso no ano seguinte em decorrência das mudanças na Coordenadoria Regional de Educação, alterada pós-eleições. 
Já a Oficina de Vídeo Oeste ou TV OVO, como é conhecida popularmente, é uma associação sem fins lucrativos, caracterizada como um meio de comunicação alternativo que trabalha simultaneamente com foco na formação profissional de jovens em situação de exclusão social, e se volta à produção audiovisual com vistas à "democratização do direito social à cultura" ${ }^{80}$. Ao longo de 16 anos ela se constituiu em espaço de atuação social de base empírica, voltado para a formação de jovens de baixa renda através de projetos de capacitação para a produção audiovisual.

Sua origem e organicidade evidenciam um forte vínculo comunitário que se explicita através de ações de comunicação comunitária dirigida às questões de cunho coletivo e de enfrentamento de adversidades decorrentes da exclusão social. Essas ações são referenciadas por meio das estratégias de produção audiovisual ao incorporar jovens da periferia, tornando-os os próprios realizadores e estimulando-os a mostrarem a realidade das comunidades onde vivem. A Oficina é ainda reconhecida por sua associação a grupos de cooperativismo local e a projetos de caráter cultural e de memória coletiva na área do audiovisual.

Com tais características, a TV OVO tem sido parceira do Canal Futura também na produção de conteúdos.

80 Site da TV OVO 


\section{O setor de Articulação e Mobilização Comunitária do Canal Futura}

O setor é considerado o "braço presencial” do canal em dezessete (17) estados brasileiros, operando com estratégias e abordagens singulares na constituição de parcerias com organizações que desenvolvem projetos próprios ou em conjunto. Desse modo, se constitui num componente diferencial e pouco habitual em uma estrutura de grande mídia. Ele corresponde à necessidade do canal de dispor, internamente, de grupos com competências interacionais para se relacionar com comunidades de caráter popular. Trata-se da disponibilização de mediadores capazes de assegurar o contato entre a instância midiática e a comunitária, e através dos quais a confiança no canal pode ser gerada, mantida ou reforçada. Tais mediadores são organizados em equipes de mobilizadores denominados de "educadores sociais", cujo papel é estratégico e vital ao modelo de gestão, uma vez que eles são os responsáveis pela articulação com os movimentos e grupos comunitários da sociedade civil. Isso exige que os mobilizadores tenham um perfil específico, capaz de mediações entre o CF e o ambiente dos grupos sociais. Tal perfil tem características apontadas pelos próprios agentes, tais como, "ter sensibilidade para questões sociais e ser disciplinado para trabalhar sozinho (...) ser comunicativo e articulador (...) ter uma boa leitura do território em que atua para realizar as escolhas mais estratégicas" ${ }^{81}$.

Por conta de tal exigência, na sua grande maioria, os mobilizadores são indicados e escolhidos entre profissionais que possuem, em sua trajetória de vida, vínculos ou vivências junto a grupos que desenvolvem ações sociais diversas. Apoiados pela equipe que assessora a gerência internamente, os mobilizadores são selecionados e contratados para atuarem especificamente em campo.

81 Respostas coletadas por questionário online junto aos mobilizadores do CF. 
São quatro equipes regionais - sul, sudeste, nordeste e norte -, que operam como grupos de trabalho e, atualmente, somam apenas dez (10) pessoas em todo o território nacional.

A equipe que atende a região sul é composta de duas pessoas, uma sediada em Porto Alegre e outra em Curitiba, sendo que ambas cobrem também o estado de Santa Catarina. A região nordeste é atendida por três mobilizadores sediados em Salvador (BA), João Pessoa (PB) e Recife (PE) e atendem, também, os estados do Maranhão, Alagoas, Sergipe e Rio Grande do Norte. Já na região Norte, dois mobilizadores estão sediados em Belém (PA) e Manaus (AM), com algumas ações no estado do Tocantins. Outros três respondem pela região sudeste com base nas capitais São Paulo e Rio de Janeiro, e cobrem Minas Gerais com ações nos estados do Espírito Santo e no Mato Grosso do Sul. Na sede central, quatro coordenadoras respondem por projetos específicos, auxiliadas por cinco assistentes e dois estagiários, além da gerência geral do setor.

Outra característica marcante desse setor é o fato de o canal operar sem sede física nas bases regionais, e sim através das equipes de mobilização que atuam na identificação, articulação e mobilização dos grupos comunitários das respectivas regiões. O contato (rotinas) entre a sede central e os mobilizadores ocorre por meio de recursos tecnológicos (telefones, e-mail, skype) e, ainda, em reuniões presenciais agendadas com antecedência entre a sede e os mobilizadores. Estas, em geral, são reuniões de avaliação e planejamento de que participam diferentes setores do CF. Tais características se dão em torno da efetivação do trabalho de campo e mobilizador das equipes.

Já no tocante ao contato das equipes com os grupos comunitários, os mobilizadores evidenciam que "nos processos vale tudo para 
contatar: fone, skype, email, facebook ... sinal de fumaça. Usamos aquilo que a pessoa / instituição possui, acha mais fácil." 82

Os deslocamentos dos mobilizadores às regiões dos grupos comunitários se dão mediante agendamento, conforme o projeto em questão. Por ocasião das implementações e formação, não raro, eles permanecem em períodos alternados de uma semana no local sede dos grupos envolvidos. $\mathrm{O}$ fato de as equipes serem exíguas faz com que frequentemente se desloquem de um território a outro.

$\mathrm{Na}$ atuação com os grupos comunitários, o foco se dá na elaboração e apoio de projetos sociais para a formação com ênfase na questão do audiovisual, desenvolvimento sustentável, direitos humanos, qualidade de vida, saúde e segurança alimentar e nutricional. E também aos projetos voltados para o atendimento da juventude, com o desenvolvimento de ações voltadas para a valorização da identidade juvenil, atuando fortemente na conscientização e no enfrentamento à violência, especialmente quanto ao extermínio da juventude negra, empreendedorismo e formação profissional para atividades locais, e o incentivo à formação audiovisual para a produção em parceria com o CF.

A ação de contato com os grupos comunitários que atuam com o CF ocorre no formato de parceria colaborativa, sem que se assumam compromissos de ordem formal ou institucional, à exceção dos trabalhos de produção de conteúdo. Desse modo, não raro, uma série de parcerias não chega a se desenvolver para além da etapa inicial, e o que parece determinar o sucesso dos projetos propostos em operações conjuntas é a intencionalidade e a articulação de cada grupo envolvido.

Uma vez identificados grupos comunitários "potenciais" aos objetivos do CF, as equipes de mobilização articulam os contatos e

82 Respostas coletadas por questionário online junto aos mobilizadores do CF. 
iniciam um trabalho junto a eles. A natureza destes trabalhos passa pelas atividades de preparação para o uso dos conteúdos (projetos e ações de recepção) ou de produção conteúdos ou, ainda, de proposição de conteúdos. A rigor, o trabalho da mobilização comunitária envolve pesquisa, capacitação, acompanhamento e avaliação mediante o monitoramento e análise dos resultados alcançados, além de ampliar o alcance da iniciativa através de oficinas, para capacitar multiplicadores. Entre as suas inúmeras atribuições e ações, está o projeto Maleta Futura, um dos principais projetos do Canal Futura, que reúne numa maleta customizada sua produção televisiva e a de seus parceiros, cuja circulação é assegurada pela via da mobilização comunitária, junto aos espaços territoriais e grupos de ação comunitária, como se verá adiante.

\section{Maleta Futura: o produto e as lógicas da interação}

No quadro das interações comunicativas estabelecidas entre os agentes participantes, no cotidiano das práticas sociais e midiáticas, visualizamos o desenvolvimento específico de um sistema de relações. As dinâmicas que envolveram a implementação do projeto Maleta Futura os processos interacionais próprios de cada participante se desenvolvem segundo lógicas muito diferenciadas. $\mathrm{O}$ fato de não haver referências práticas sobre modos de interagir leva a táticas tentativas e à experimentação interacional para a geração de dispositivos pertinentes.

O projeto Maleta Futura foi gestado durante o ano de 2006, já no período de transição de foco do Canal Futura, entre o setor de conteúdo e o de articulação e mobilização comunitária, como proposta para solucionar um hiato que se tinha evidenciado no espaço entre a produção e a distribuição/redistribuição dos conteúdos do canal. Tal hiato era caracterizado pelo não acompanhamento do 
percurso dos programas e demais produtos midiáticos que saíam do canal pela via da articulação e da mobilização comunitária. Não havia como monitorar efetivamente a circulação dos conteúdos.

Relatos das equipes de mobilizadores confirmam a informação de que, desde a criação do canal, sempre houve uma demanda alta de acesso aos conteúdos do CF por instituições como escolas, presídios, creches e hospitais. Estas contatavam diretamente a Central de Atendimento ao Telespectador (CAT), ou chegavam através das equipes de mobilização que atuavam, entre outras frentes, no auxílio à criação de videotecas nas entidades parceiras. Desse modo, os programas eram copiados e distribuídos via correio ou pela via da mobilização (Finguerut, S. \& Sukman, H., 2008), sem que houvesse qualquer registro sobre tal distribuição ou o alcance da circulação, como já referido anteriormente.

A proposta do projeto Maleta, além de organizar a distribuição, organizou o público do $\mathrm{CF}$, estabelecendo canais de troca na medida em que se propõe, também, a articular a rede de parceiros do canal.

Desde o lançamento do projeto, cinco maletas já foram implementadas - Toda Beleza (2006), Meio Ambiente (2008), Democracia (2010), Saúde (2011), Infância (2013) ${ }^{83}$ e uma sexta, está sendo preparada dentro da parceria do CF com a ONG Steps Internationa ${ }^{84}$ que lançou globalmente, em 2012, o projeto transmídia Why

83 As Maletas são projetadas e desenvolvidas em um ano e executadas no ano seguinte. As datas em parênteses são referentes ao ano de sua implementação.

84 A Steps International é uma organização sem fins lucrativos que reúne documentaristas do mundo todo unindo "novas mídias à velha mídia" para divulgar e debater globalmente questões mundiais, e atua em parceria com outras organizações e fundações internacionais. O projeto 'Por que Pobreza?' foi construído em continuidade ao projeto 'Por que Democracia?' lançado em 2007. Grifos da pesquisadora em versão livre do site da Organização. 
Poverty ${ }^{85}$ visando mobilizar as pessoas no enfrentamento da questão da pobreza.

\section{A proposta e seu alcance}

Enquanto parte das estratégias do CF para além da TV, o projeto Maleta Futura ${ }^{86}$ se caracteriza como uma ação transversal, de mobilização comunitária, com foco na implementação, distribuição e redistribuição de conteúdos do canal e de seus parceiros.

É considerado um projeto "guarda-chuva" porque reúne a seleção de parte da produção televisiva do Canal Futura de acordo com recortes temáticos e abrangentes, alinhado com as políticas internas do canal, e voltado para o trabalho junto às entidades que compõem as redes articuladas por ele em todo o Brasil.

Do ponto de vista midiático, ele integra tanto a proposta de desenvolvimento e circulação de conteúdos, quanto as estratégias das ações de mobilização comunitária do $\mathrm{CF}$, ao envolver diferentes grupos comunitários em torno de temáticas específicas e metodologias experimentais.

Apesar de uma proposta de descentralização, o projeto é elaborado em parceria entre o setor de Conteúdo e o de Mobilização e Articulação Comunitária, sem que essa interação necessariamente se concretize ou se materialize na produção de conteúdos diferenciados. Ele remete sim, de um lado, aos compromissos institucionais do canal com os parceiros que asseguram a sua sustentabilidade e, de outro, à perspectiva "comunitária" do próprio CF em sua proposta

\footnotetext{
85 O projeto pode ser acessado em http://www.whypoverty.net/en/

86 As maletas circulam em 974 municípios de 27 Estados, sendo que a Fundação Bradesco, a Federação das Indústrias do Estado de São Paulo (FIESP) e a Federação das Indústrias do Estado do Rio de Janeiro (FIRJAN) despontam como os maiores apoiadores do projeto.
} 
enunciada de ser um canal educativo que atua na horizontalidade do social.

É nesse sentido que se afirma ser a implementação do projeto Maleta Futura, enquanto sistema, uma processualidade aberta. Por um lado, ela é resultante das mudanças que implicaram reconfigurações nos modos de contato e interações com a comunidade através de operações múltiplas com foco na distribuição e circulação dos conteúdos do CF e dos seus parceiros na sociedade. Por outro, o Canal Futura não tem como dimensionar ou controlar os resultados e empregos que os seus parceiros comunitários farão com elas em seus territórios.

Desse modo, o esforço do canal se traduz na tentativa de monitorar/avaliar os resultados decorrentes de suas estratégias operacionais em torno do projeto, contando para tanto com a participação dos parceiros envolvidos e de especialistas.

Sua estratégia de contato prevê o convite às 'instituições de referência ${ }^{\text {'87 }}$, identificadas pelas equipes de Articulação e Mobilização, a fim de que a Maleta Futura seja agregada às ações já realizadas por aquelas em seu cotidiano. Em tal cenário, ela chega aos grupos como um elemento fortalecedor dos conceitos e das ações já trabalhadas pelas instituições/organizações e, segundo a perspectiva dos mobilizadores entrevistados, com a proposta de provocar reflexão sobre a realidade local e incentivar iniciativas que busquem a transformação social.

Seu modo de operar envolve diferentes etapas. Uma vez definido o tema e a pesquisa do material que irá compor o acervo de cada maleta, passa-se à produção, isto é, ao processo de pesquisa de

87 Terminologia utilizada pelo CF para identificar seus parceiros. Percebemos que nos documentos do CF e na fala de suas equipes, o emprego do termo oscila conforme o seu contexto de origem, sendo correlato às expressões 'parceiro principal', 'parceiro cabeça de rede', 'parceiro institucional'. 
materiais com parceiros nos territórios, à escolha dos programas, à elaboração de conteúdo do caderno de atividades e à confecção da maleta produto.

A maleta é portátil, atraente tanto pela estética quanto pelos produtos que oferta, quase uma biblioteca portátil, considerandose que a produção entra como livro didático/audiovisual. É de altíssima rotatividade, o que possibilita diferentes estratégias de uso conforme projetos e finalidades das instituições parceiras.

Ela possui o formato de uma mala similar à dos caixeiros viajantes e é customizada com o logotipo e imagens coloridas que remetem aos conteúdos temáticos do $\mathrm{CF}$ da edição vigente. Tal formato foi escolhido por associar o projeto ao caráter itinerante do caixeiro viajante que vai a todos os lugares, mesmo aqueles inimagináveis, e também para sugerir a possibilidade de os usuários incluírem nela novos materiais. Trata-se de uma tentativa de estimular o que o canal denomina "articulações intercomunitárias" entre instituições com afinidade temática.

Cada maleta traz uma compilação temática dos programas mais recentes e abrangentes do canal, reunida a materiais impressos e inéditos elaborados por equipes próprias em parceria com consultores externos. Inclui, ainda, produtos pedagógicos, entre lúdicos e didáticos, bem como materiais temáticos de organizações e instituições parceiras. Além da maleta completa, há a "maletinha" (maleta básica), uma versão simplificada do kit e entregue ao parceiro comunitário denominado "cabeça de rede" para auxiliar no trabalho junto aos pares. Foi criada com o objetivo de garantir a circulação dos conteúdos a um maior número de envolvidos sem onerar o orçamento do projeto.

Paralelamente, as equipes de mobilização e articulação comunitária em cada região mapeiam instituições de referência que atuam como articuladoras de redes em seus territórios para levar 
até elas a proposta do projeto. No momento em que aderem ao projeto, as instituições assinam um termo de cooperação técnica com o Canal e passam a contar, durante dois anos, com o apoio das equipes de mobilização e articulação comunitária para a implementação das Maletas. Isto se dá através de visitas de acompanhamento aos parceiros envolvidos, da realização de grupos focais ou de reuniões de socialização das atividades com outras instituições participantes e consultores.

A instituição de referência, ou cabeça de rede no jargão televisivo, assume a responsabilidade de "replicar" a Maleta. Para tanto, recebe a Maleta Futura completa e indica seus parceiros para receberem as "maletinhas" ou Maletas Básicas.

Uma vez fechada a parceria, durante os dois anos em que as equipes de mobilização e articulação comunitária do canal assessoram os grupos, elas também asseguram a participação do CF nas agendas estratégicas das organizações parceiras, e realizam atividades de formação sobre a utilização do acervo, sugestões metodológicas sobre como trabalhar temas e jogos disponíveis na maleta, monitoram os planos traçados para verificar se serão necessárias adequações, orientam sobre a alimentação online do sistema - este monitoramento também se dá por telefone - e, ainda, atuam na avaliação final, uma vez que o CF pretende "manter a rede de parceiros com ocasional envio de materiais relacionados e canal de comunicação aberto pelo site do projeto" ${ }^{88}$.

Ainda que o projeto seja colocado em circulação com estratégias e normas já definidas na instância da produção, uma vez entregue aos grupos comunitários a Maleta fica aberta aos usos que estes façam de seus conteúdos. Os modos de uso e de circulação dos conteúdos, sua seleção e distribuição na rede de parceiros de

88 Site do CF. 
cada grupo comunitário ficam na dependência dos fluxos instituídos pelos interesses e estratégias destes, e não necessariamente na observância das metodologias sugeridas pelo CF. Do mesmo modo, os relatos e retorno destes usos ao canal dependem da disponibilidade e da capacidade de instituir uma prática de registro em cada grupo.

\section{Os processos e os resultados}

Uma vez determinado o tema de cada edição do projeto das maletas, a definição dos conteúdos que constituirão cada uma delas passa pela realização de fóruns temáticos com representantes das ONGs, das instituições sociais e de profissionais especializados na área especifica do projeto. Tais fóruns são apontados como necessários ao estabelecimento dos pontos prioritários a serem abordados através dos conteúdos dos vídeos que serão incluídos em cada maleta, bem como os materiais vindos dos parceiros de referência na temática em questão.

No entanto, ainda que permita a inclusão de novos produtos para a circulação, é a instância da produção no CF que determina os conteúdos na tentativa de assegurar o controle do processo de produção dos sentidos. Por conta disso, o projeto Maleta se mantém praticamente inalterado enquanto modelo, com poucas referências no tocante à inclusão das reivindicações dos parceiros comunitários. Seu formato tem se mantido e ele se apresenta como um dos projetos mais "estáveis" dentro da oferta do canal. Nesse sentido, opera como matriz organizativa, obedecendo a regularidades ditadas pelo quadro de referências para a sua produção. Tal regularidade se faz presente nos materiais do canal e indica processos mistos de aprendizagem e socialização. Neles as tentativas bem sucedidas são incorporadas ao modelo viável, isto é, o que funciona bem se torna 
modelo e gera um padrão. Ao mesmo tempo, significa que quem quiser entrar no sistema do canal, terá que operar dentro desse modelo.

As equipes de mobilização do $\mathrm{CF}$ se responsabilizam pelas parcerias com instituições e organizações de referência em cada região, como já foi mencionado anteriormente. Os critérios utilizados para selecionar estes parceiros apontam para as organizações de referência na temática eleita, para a atuação em rede de cada um deles, e para sua capacidade de capilarizar ações para outras regiões.

Cada organização de referência ou "cabeça de rede" assume a responsabilidade de identificar instituições ou organizações que trabalhem direta ou indiretamente com ações em torno da temática específica de cada maleta. As cabeças de rede recebem a maleta completa e os parceiros indicados por elas recebem a maleta básica para uso em ações pedagógicas.

Ao aderir ao projeto, os parceiros firmam um acordo de cooperação técnica e passam a receber o suporte das equipes de mobilização do canal para a implementação da maleta, como explicado anteriormente.

A cada edição, o projeto é avaliado em seus processos e resultados através da análise das informações do banco de dados, da realização de grupos focais e da observação participante, além de pesquisa espontânea realizada por consultores contratados para tal. As avaliações anuais focam no perfil do público e da audiência, e na realização de grupos focais sobre os programas e projetos especiais.

A última pesquisa exploratória encomendada pela FRM para avaliar os indicadores das quatro edições anteriores da maleta, cujos dados foram referidos no item imediatamente anterior, se deu por amostragem regional junto às instituições cabeça de rede. Foram consideradas as dimensões relacionadas ao uso e finalidades das maletas, ao papel dos mobilizadores para as ações e à relevância 
dos materiais para os parceiros. A pesquisa "espontânea" era feita por telefone com os parceiros do canal em diferentes territórios e as questões a serem respondidas eram as mesmas entregues por ocasião do recebimento da maleta, com variações dependendo do diálogo estabelecido. As questões discorriam então sobre os modos de usar, a ação desenvolvida e a sua natureza, o perfil e o número de participantes, os programas utilizados, sobre os materiais complementares, trabalhos em parceria com outras instituições, objetivos atingidos e resultados obtidos com a atividade.

Neste aspecto, foi observado que o monitoramento e a retroalimentação das informações se dão, na maior parte das vezes, através do contato direto com as equipes de mobilização, seja presencial ou telefônico, apesar de o canal ter implantado um sistema de banco de dados online para o acompanhamento do emprego da Maleta. Nesse, as instituições cabeças de rede, mediante senha de acesso, são responsáveis pelo registro das ações dos parceiros no banco de dados do projeto. No entanto, observamos que em tais operações não há garantias, o que permite pensar que a atuação do midiático, a partir da proposta do canal, torna-se altamente volátil e, ao mesmo tempo, exatamente por isto, se caracteriza por uma celeridade peculiar na busca da superação das supostas "falhas" que emergem destas tentativas.

De fato, as informações orais concedidas de modo informal indicam um movimento maior do que o registrado habitualmente no sistema do canal. Esse fluxo descontínuo remete a uma tarefa árdua e presencial dos mobilizadores, que consiste na tentativa de resgatar a memória dos grupos em torno das atividades executadas. Indicam também um descompasso entre o sistema de monitoramento do canal e o modus operandi dos grupos parceiros, pouco habituados ou com pouca disponibilidade de pessoal e conhecimento técnico para produzir relatórios. Mesmo em grupos mais 
articulados, a prática do relatório é vista como um 'trabalho a mais ${ }^{89}$ a ser produzido.

Conforme pesquisas do CF, apenas $25 \%$ das informações completas sobre as atividades desenvolvidas com o projeto Maleta retornam ao canal. Ao mesmo tempo, este retorno restrito e mesmo a lentidão da postagem dos dados têm gerado o aperfeiçoamento do sistema e a busca de novos modelos de avaliação. Isto fez com que também o banco de dados desenvolvido para o preenchimento dos relatórios das associações parceiras fosse reformulado, facilitando e ampliando o acesso para registros das atividades desenvolvidas.

No sistema original, apenas o parceiro de rede tinha acesso ao banco de dados para registro. Uma nova atualização do mesmo permite que os demais participantes do projeto acessem a área para registro dos dados, permitindo assim mais registros acerca das ações executadas.

Segundo a compilação dos dados informados pelos parceiros "cabeças de rede", 75\% das informações relativas às ações realizadas com a maleta estão incompletas. Do total das informações retornadas, somente $25 \%$ permitem uma visão global das ações realizadas e do número de participantes.

No entanto, tais dados mensuráveis não necessariamente são fidedignos. Nos relatos orais obtidos durante este estudo, há indicações de que os números podem ser "adequados" na instância dos parceiros comunitários de modo a atender as exigências do projeto $^{90}$. Tal atitude sinaliza, ao mesmo tempo, a dificuldade de parte dos parceiros comunitários em entender o preenchimento do formulário cedido pelo canal, como também a intencionalidade

89 Informações verbais tantos dos mobilizadores quanto dos membros dos grupos em momentos distintos.

90 Informação verbal, obtida junto aos grupos comunitários analisados. 
decorrente da compreensão do que realmente importa dentro da lógica de oferta da instância midiática.

\section{As práticas sociais comunitárias}

Observamos que, além de ser um produto, a maleta é um objeto em circulação, criado já na previsão de circuitos específicos, distintos dos mais habituais a que se remetem os produtos da indústria televisual. E, além disso, o produto agrega em seu percurso processos diferenciados, frequentemente não previstos no momento da produção.

Uma das características dessa ênfase no circuito é o fato de que, como todo produto serial, a instância produtora se obriga a monitorar a circulação - a geração de processos sociais aderentes e/ou tensionadores, na busca das incidências que possam levar a modificações de futuras edições ou à criação de novos produtos relacionados. E apesar dessa monitoração, os circuitos mantém sempre certa autonomia no que se refere ao uso, ao desvio, às apropriações segundo lógicas próprias, a reinvenções a partir do produto, quando o fazem seguir adiante.

Considerando-se o cenário das práticas sociais dos grupos comunitários, cabe ponderar que os parceiros comunitários são também agregadores de usuários não mais na condição habitual dos receptores de televisão. Estes se relacionam com os produtos televisivos do CF por práticas e vínculos "individualizados" ou, ainda, em pequenos grupos dispersos em ambientes múltiplos, muitos deles de caráter experimental, acionados pelos próprios parceiros.

Ambos os grupos, asseguradas as suas especificidades, possuem uma peculiar capacidade de articulação e mobilização em rede, com o desenvolvimento de metodologias próprias e inovadoras utilizadas de modo singular no processo de apropriação/ 
redistribuição das Maletas Futura, característica essa que também assegurou a continuidade da parceria com o canal em diferentes projetos e atividades.

Ações de articulação e planejamento dos grupos comunitários evidenciaram, nessa ordem de operações, uma série de iniciativas autônomas que redesenham as regras definidas pelo CF na origem. Podemos situar entre eles a preparação de sessões para exibições coletivas dos vídeos que compõem os kits das maletas em salas e em outros espaços constituídos especialmente para tal, seguidas de debates sobre os conteúdos disponibilizados e utilizados de acordo com os interesses específicos dos grupos. Não raramente, estes materiais são colocados em circulação por operações outras não previstas pelas metodologias do CF. Como exemplo, a reprodução não formalmente autorizada, mas consentida tacitamente dos vídeos fornecidos pelo CF no momento da entrega das maletas. As cópias são distribuídas entre os parceiros de rede, ou ainda, pelas entidades e organizações em sistemas próprios desenvolvidos para empréstimo com fins de uso coletivo ou individual. Em decorrência, gerou-se aí um sistema denominado "Maleta itinerante" que prevê o rodízio das maletas entre os pares por um determinado tempo, uma vez que o número dos kits não atende toda a rede de parceiros dos grupos. Dada a sua funcionalidade, este modelo foi incorporado pelo canal junto a outros grupos.

Também nesse contexto de ações, de experimentações e de negociações é comum que grupos migrem dos seus papéis habituais para assumirem o papel de produtores midiáticos, colocando em circulação conteúdos próprios.

Por ocasião da implementação do projeto Maleta Futura, a ação do GEGV gerou uma rede, inicialmente com 10 instituições parceiras que utilizaram os conteúdos em diferentes contextos e maneiras, com finalidade pedagógica. Para eles, a proximidade com 
o CF se dá "dentro de um processo colaborativo que executa (...) uma didática prática, para incluir nossas pautas na grade das programações do maior grupo de comunicação do país. E esta questão não nos assusta" (informação verbal) ${ }^{91}$. O fato de o CF pertencer às Organizações Globo "não é mais importante do que a disponibilidade do instrumento para fazer o que estamos fazendo" (informação verbal)..$^{22}$

Já no caso da TV OVO em Santa Maria, além da utilização das maletas nas oficinas de formação que promove, as ações desenvolvidas ampliaram a zona de atuação do grupo, atingindo o sistema formal de ensino através da Coordenadoria Estadual de Educação ( $\left.8^{\mathrm{a}} \mathrm{DE}\right)$ e da Secretaria Municipal de Educação.

A parceria estabelecida reconduziu os conteúdos das maletas às instituições de ensino. A TV OVO repassa os materiais das maletas às escolas da rede pública de ensino de Santa Maria, ficando a cargo dos professores a escolha e o modo de uso dos programas disponibilizados nas maletas, que serão utilizados conforme seus objetivos e necessidades.

O retorno acerca de tais usos é constituído por relatórios parcialmente registrados e por relatos orais sobre a participação dos alunos, sobre a busca de mais informações relativas aos assuntos abordados e sobre percepções diversas a respeito dos conteúdos da maleta.

91 Entrevista com Carlos Eduardo Sanders (Preto), um dos coordenadores do GEGV, 18 de outubro de 2010.

92 Entrevista de Glauco Roberto Marins Polita à pesquisadora, em 18 outubro de 2010. 
Como é evidente, das diferentes práticas e objetivos dos grupos comunitários, decorrem interações diferenciadas com o parceiro televisual, fazendo variar as negociações possíveis e o próprio sistema de relações entre os parceiros.

Dados os processos da TV OVO, como produtora de vídeo, o padrão de valorização estética do polo de produção do CF levou a um conflito entre a equipe da TV OVO e o setor de produção de jornalismo do canal, quando os vídeos realizados pelo grupo necessitaram ser editados diversas vezes antes de serem exibidos nas telas do canal.

Para além do conflito, o episódio remete à evidência do lugar e do fazer de cada equipe. E isto levou a padrões específicos de interação do grupo da TV OVO com as diferentes equipes do canal. Há um diferencial significativo nas dinâmicas interacionais quando o trabalho envolve a equipe de mobilização ou as equipes da sede. $\mathrm{Na}$ esfera da mobilização a interação é direta e as escutas acontecem de parte a parte em trocas muito mais produtivas e significativas. $\mathrm{O}$ mesmo não ocorre quando se trata do contato com as equipes na sede do canal. Enquanto as relações com as equipes de mobilização tornam-se pessoalizadas, não há, por parte da sede, uma escuta direta e não mediada.

Somado a outros episódios que confirmaram tal evidência, pudemos inferir que para a TV OVO, a possibilidade de parceria com o CF dependerá sempre da interação com as equipes de mobilização. A própria natureza das atividades desenvolvidas pela TV OVO nos faz perceber as contradições que emanam do CF e do próprio projeto Maleta Futura. A confiabilidade do canal se concentra nas equipes de mobilização e na sua capacidade de desenvolver uma escuta produtiva.

O GEGV evidencia que o espaço principal de articulação é igualmente o da equipe de mobilização - mas sua atuação de 
movimento ambientalista favorece relações com o CF também em outras perspectivas. O Futura é uma referência midiática que representa a possibilidade de maior visibilidade e aporte ao trabalho desenvolvido. Essa referência lhes aumenta a legitimidade junto à comunidade e instituições locais. Para alguns integrantes da rede, essa percepção vai mesmo um pouco além, e o canal assume o papel de articulador do próprio movimento, na medida em que parte de suas operações também instrumentalizam as ações dos grupos. Nesse sentido, o CF pode ser requisitado como um consultor capaz de qualificar as ações desenvolvidas pelos grupos do movimento.

\section{Conclusão: lógicas do dispositivo}

No terreno de operações do CF, a observação do setor da mobilização evidencia - mais agudamente que na produção televisiva - que as determinações das direções não são cumpridas de forma mecânica, mas sim negociadas em distintas ocasiões e situações.

As reuniões de planejamento, que envolvem tanto o setor de articulação e mobilização como o de conteúdo, são a ocasião em que os mobilizadores expõem seu próprio ponto de vista, e podem reafirmar ou se contrapor ao de outras instâncias da produção. Também é quando trazem para o canal a percepção e a escuta dos grupos e movimentos que integram a rede. Tal escuta, realizada pelos mobilizadores, informa os resultados das operacionalidades empreendidas nos territórios; e compõe o quadro de expectativas do Canal sobre seus parceiros.

Tais momentos abrem possibilidades no contexto televisivo para a via da experiência, das experimentações produtoras de sentido e de identidades. As referências, trazidas pelos mobilizadores de suas interações em campo, são buscadas para o desenvolvimento 
de novas ideias e criações. Delas podem emergir novos produtos, como é o caso do programa Diz Aí, voltado para a juventude do meio rural e negociado pela instância da mobilização; ou, ainda, a inclusão de novos temas dentro de projetos, como foi o caso da Araucária, entre outras espécies do Bioma Pampa e da Mata Atlântica no programa Um pé de quê? da Maleta Meio Ambiente, levado ao CF como sugestão do GEGV. Ou ainda a própria reavaliação do sistema de monitoramento de resultados do projeto Maleta que necessitou levar em consideração as diferentes condições em que se encontram os grupos comunitários, sinalizada pelos mobilizadores.

Isto torna possível visualizar, na esfera de interação entre o CF e os grupos comunitários, o predomínio da experimentalidade, revelando que muitas das decisões tomadas em relação à produção ocorrem e decorrem do âmbito das negociações e experiências vividas pelos participantes da instância midiática junto àqueles grupos. Nessa direção, podemos inferir ser este um sistema em processualidade inicial, aberto, em que as tentativas implicam invenção por ensaio e erro.

Com as maletas, o canal reúne não só os produtos televisuais, mas assegura as articulações em torno do projeto e das temáticas. Nessa linha de percepções, observando a ênfase dada à mensurabilidade do projeto, verifica-se que no polo da produção, em consequência do seu alcance, o projeto é enunciado como um potencial multiplicador de usuários em rede. Representa, por conta disso, uma "moeda de troca" junto aos parceiros mantenedores, que asseguram o financiamento necessário para a produção do Canal, além de atuarem em outras instâncias e projetos do CF.

Já nos territórios onde elas circulam, efetivamente suprem os grupos e movimentos de materiais e de táticas didáticas em favor das causas tematizadas. $\mathrm{Na}$ instância do comunitário é nítida a 
referência à qualidade dos materiais ofertados e ao suporte dado pelas equipes de mobilização, apontado como fundamental ao próprio aperfeiçoamento do trabalho dos grupos envolvidos.

Se através da maleta podemos inferir que o CF busca "pedagogicamente" dar forma às práticas sociais, cabe referir também que os usuários em seu cotidiano "produzem usos ou maneiras de fazer mais complexas do que o simples consumo. Essas táticas constituem as mil práticas pelas quais os usuários se reapropriam do espaço, organizados pelas técnicas da produção sociocultural" (Certeau, 2012, p. 41).É justamente essa possibilidade de diferentes táticas de uso que estabelece uma sistemática de circulação que a desvincula da tendência de controles centralizados na produção/distribuição. Em outras palavras, a maleta pode funcionar como um objeto a ser acionado de modo relativamente independente tanto pelo polo produtor, quanto pelo polo usuário. Sobre o produto assim organizado, com tendência de diversificação e de modularização, os usuários podem desenvolver crescentemente reivindicações (e o fazem), levando o polo produtor a um atendimento pelo menos parcial destas, tendo em vista a sua busca de agregar usuários.

Do ponto de vista do dispositivo interacional, isso pode reforçar o aspecto "escuta", de parte a parte, implicando o aperfeiçoamento possível da comunicação. Concordamos com Braga (2012c, p. 48) ao afirmar que através da escuta "pelas delicadezas de ajuste de endereçamento (...) alguma coisa retroage, 'modificando' a produção a partir das expectativas sobre sua recepção e pela repercussão destas expectativas na configuração das falas". Constatamos isso quando percebemos com alguma frequência, nos grupos comunitários analisados, as práticas subverterem as normativas do canal, conforme seus interesses de usuários.

Cabe considerar a Maleta Futura e os seus conteúdos como parte das estratégias de comunicabilidade do $\mathrm{CF}$, sendo preciso 
reconhecer nessa processualidade um conjunto de regras referidas, explicitamente ou não, para que se realizem processos comunicacionais do ponto de vista da recepção/produção. No entanto, enquanto as operações do CF, mediadas pelos mobilizadores, evidenciavam que as regularidades da chamada televisão educativa implicam lentidão quando ela busca ser pedagógica, porque aposta na linearidade da aprendizagem e no regramento hierárquico dos usos, os movimentos comunitários se mostraram ágeis na reelaboração da proposta e das estratégias, movidos pelas urgências de suas práticas. Nessa operacionalidade, criam-se circuitos comunicacionais outros, não previstos pelo polo da produção. E na medida em que retornam ao canal na forma de relatos de experiências, podem efetivamente, modificar, em parte, a produção. Claro que há graus de escuta, bem como variações complexas no acolhimento da mesma. Nesse sentido, o potencial propriamente pedagógico da maleta está exatamente nas múltiplas possibilidades de relações que se estabelecem a partir do seu uso.

Outro aspecto observado em torno dos processos de escuta refere-se à percepção dos grupos comunitários quanto às diferentes instâncias do canal e suas ações. Essa percepção das dinâmicas produtoras de sentidos corrobora a proposta de Braga (2012d), que "é da reverberação mútua entre "falas" e "escutas", de parte a parte, que se alimentam os processos interacionais em sua produção de sentido". Tais observações resultam de episódios distintos nas dinâmicas interacionais em tentativas de acertos e produção.

Nos casos investigados, as processualidades analisadas indicam uma mobilidade tal, de parte a parte, que as estratégias evidenciam na circulação social dos sentidos um espaço de reconhecimento e de desvios produzidos pelas dinâmicas de apropriação. Nesse cenário se configuram processos tentativos cuja continuidade permite que sejam montados padrões e regras geradas a partir das próprias estratégias em ação. 


\section{Entrevistas:}

Dentre as entrevistas feitas para a tese de doutoramento "Dispositivos interacionais e interações midiatizadas: um estudo sobre a implementação do Projeto Maleta Futura, Canal Futura, em Santa Maria e Passo Fundo/RS”, entre 2010 e 2013 foram aproveitadas para o presente estudo:

PIOVESAN, Zilda; RAMOS, Cleusa - do Canal Futura

BORBA, Marcos; MOMBELLI, Neli; TAVARES, Paulo - da TV OVO

POLITA, Glauco; SANDERS, Carlos Eduardo - da Rede GEGV

\section{Sites consultados}

Canal Futura: www.futura.org.br

Fundação Roberto Marinho: www.frm.org.br

Grupo Ecológico Guardiões da Vida: www.grupoguardioesdavida. blogspot.com.br/

Oficina de Video Oeste: www.tvovo.org

Steps international: http://www.steps.co.za/

Why Poverty: http://www.whypoverty.net/ 


\title{
Suíte $\mathrm{n}^{0} 5$
}

\section{“TV \& Comunidades", de Rosana Zucolo}

\author{
José Luiz Braga
}

O texto de Rosana é explícito na busca das lógicas interacionais dos episódios observados, apresentando claramente seus componentes, seus processos mais estabelecidos e seus aspectos experimentais. Mostra três espaços principais de práticas. Em dois desses espaços, encontramos, entre outros processos, mais tentativos, as táticas interacionais mais estabelecidas em cada um, que caracterizam o sistema de relações internas e funcionam como base compartilhada entre os agentes "internos" diretamente relacionados. No terceiro âmbito e justamente porque a experiência corresponde a obter interações entre os dois primeiros, está o lugar mais visível da experimentação, com linhas de compartilhamento a serem construídas entre os dois outros, pela experiência prática tentativa.

Rosana informa inicialmente os dois conjuntos básicos de agentes/processos - os pertinentes ao campo televisual e os comunitários - como é evidente, muito distantes entre si, por suas práticas comunicacionais, seus objetivos e seus sistemas de relações. A lógica televisual, de tipo midiático organizado em processo de um para muitos, é centrada em produtos audiovisuais planejados profissionalmente, focados em recepção diferida e difusa. A circulação se pensa circunscrita a esse encaminhamento do produto que vai da emissão à recepção - e tem que contar com a atividade interpretativa desse polo, sem controle da chegada, aí, dos sentidos pretendidos. 
A outra lógica, comunitária, é de tipo presencial, diversificada, com ênfase conversacional. Onde há geração de produtos, estes se fazem na negociação de objetivos mais ou menos pontuais, em relativa proximidade e contato com os usuários e seus objetivos ${ }^{93}$.

O que vai ser tentado é, sobretudo, uma composição entre os dois processos, de suas ofertas específicas de modo interacional, buscando as complementações só viáveis, para cada parceiro, no modo de se comunicar do outro.

A dificuldade evidente de fazer interagir entre si tais lógicas interacionais e a necessidade de constituir um elo de compartilhamento sobre o qual outras lógicas se desenvolvam é o que vai determinar a constituição do terceiro conjunto de agentes - na forma de um setor de articulação e mobilização comunitária pelo canal de TV.

O setor é instituído pelos responsáveis do dispositivo televisual pela organização de uma espécie de assessoria de contato, que possa atender às diretivas da televisão - e portanto, a suas lógicas de campo social. Por outro lado, os agentes individuais que vão compor o grupo são selecionados dentre especialistas que detêm a experiência "do outro lado" - na ação comunitária. Porque são os que conhecem o ambiente e a "linguagem"; que sabem dos objetivos e dos procedimentos. Em suma, que podem se mover com facilidade no sistema de relações próprio aos dispositivos comunitários.

A lógica geral desse movimento de constituição do "terceiro grupo" é bastante conhecida, em termos abrangentes: trata-se de um acionamento do "dispositivo intérprete". Essa figura seria basicamente definida como aquele que conhece as duas linguagens postas em contato, para viabilizar a interação entre os detentores

93 É verdade que um dos grupos comunitários, a TV OVO, é também produtora de material televisual. Seria talvez uma situação intermediária. 
de uma e de outra parte. Tais atividades de mediação são frequentes em muitos tipos e tentativas de comunicação ${ }^{94}$.

Específico da situação, entretanto, é que os agentes de articulação referidos no capítulo não são exatamente conhecedores das duas linguagens - vêm de uma delas, e são contratados da outra. A relação com um dos lados é a de conhecimento e prática; com o outro, a de vínculo profissional e de distribuição de tarefas (que, de certo modo, são componentes da "linguagem" empresarial). A expectativa é de que essa relação "de serviço" de algum modo os aproxime da lógica interacional interessada. Este seria, aliás, um padrão histórico: na ausência de intérpretes enquanto efetivos conhecedores de duas linguagens (de dois sistemas interacionais), é por aproximação tentativa que se desenvolve, por processos práticos, tal perfil. Depois de certo tempo e variadas tentativas, acabam se formando mediadores através do ensaio-e-erro e da exercitação, que podem se locomover então entre as diferentes práticas, tornando-se esta "duplicação" a sua prática.

O sistema de articulação chama a atenção para aspecto que complementa as diferenças já observadas entre as duas lógicas interacionais postas em contato na experiência. Em uma delas, o que se solicita é o engajamento pessoalizado, na articulação de interesses comuns, processos que enfatizam táticas colaborativas desenvolvidas no próprio campo de operações. Na outra lógica, de ordem profissional, as pessoas são selecionadas por competências especificadas e, em função de tarefas previstas, se enquadram em um padrão salarial de contraprestação.

94 Pode-se considerar que o conhecido processo do "two step flow of information", estudado por Lazarsfeld, corresponde ao desenvolvimento, na sociedade, de um perfil deste tipo de "conhecedor" prático, por seletividade espontânea - os mais perceptivos sobre a intersecção entre processos midiáticos e os temas em pauta assumiam a posição de lideranças de opinião. 
Constata-se, então, a transição de certo número de pessoas - os agentes de articulação e mobilização - de primeira lógica interacional e de trabalho para a segunda; com a expectativa de que as tarefas dirigidas, aí atribuídas, sejam então "transferidas" para a lógica de ação do outro parceiro, através de uma espécie de "aprendizagem de linguagens".

No espaço comunitário, a expectativa é inversa: agentes com a experiência de processos comunitários seriam verdadeiros "representantes" seus, dentro mesmo da estrutura formalizada do canal de televisão.

O capítulo observa os movimentos desses três grupos de agentes (e de lógicas interacionais) no exercício de episódios que caracterizam a circulação das maletas de produtos. A maleta, mesmo, já se manifesta como produto especial - parcialmente elaborado nas lógicas de uma produtora de televisão; parcialmente concebido como material para circulação "de mão em mão", na lógica dos processos comunitários. Seu próprio desenvolvimento é já resultante de aproximações tentativas para ajustes entre dois circuitos habituais antes não conectados.

A circunstância de "sociedade em midiatização" envolve não apenas um uso crescente de processos midiáticos por setores sociais não vinculados ao "campo dos media"; como também - com frequência - passam a ocorrer articulações complexas entre circuitos "de mídia" e circuitos outros. A experiência implica não apenas a invenção social de articulações entre diferentes circuitos existentes - mas sobretudo envolve transformações de cada um dos circuitos anteriores (ou trechos de circuitos), em que cada um deve ajustar, a montante e a jusante, seus próprios processos antes apenas "internos", para viabilizar uma circulação redirecionada.

Por isso mesmo, não é apenas o "módulo de ligação" (formado pelos articuladores / mobilizadores) que se caracteriza como 
dispositivo interacional experimental. Todos os episódios entre as lógicas comunitárias e as lógicas televisuais de produção de sentidos compartilham a geração do dispositivo interacional em construção. A modelização de processos de compartilhamento e a geração de outras lógicas se fazem pelo ajuste de práticas anteriores; e pela invenção de processos, de parte a parte, que assegurem a circulação ampliada nas duas direções entre os grupos.

A autora nos relata, em sua tese sobre o tema (Zucolo, 2014), os movimentos tentativos do processo de elaboração que acompanhou e esquadrinhou. A cada visita a campo, para sua pesquisa, percebia que os procedimentos, as tarefas e os próprios objetivos se modificavam. Aparecem, naturalmente, descompassos entre proposições, expectativas e respostas, de parte a parte. Certamente, os parceiros dispõem de diferentes estruturas de poder, e a experiência se desenvolve talvez mais perto da "zona de pregnância" (Fausto Neto, 2008b) do canal de televisão. Mas como a pesquisa de Rosana atesta, o parceiro comunitário dispõe também de recursos interacionais para assegurar seus objetivos.

Podemos facilmente imaginar o papel dos agentes de articulação - vinculados pela experiência a um dos lados participantes; e pela relação profissional, ao outro - com uma notação quase diplomática de asseguradores da interação e da fluência dos processos. Esse desempenho principal, nas negociações, enfatiza uma "transmissão da escuta" entre as partes. Tudo isso, evidentemente, um pouco tateante, uma vez que apenas a confirmação prática da eficácia de um processo e de uma satisfação mínima de expectativas diversas (eventualmente conflitantes, ou de direções divergentes) viabiliza uma reiteração, sempre sujeita a mudanças, mas necessária como teste mesmo para a constituição de padrões de comportamento.

Trata-se de um exemplo claro de situação em que as estratégias é que desenvolvem as regras (ao contrário do que é mais facilmente 
percebido, quando as regras direcionam a variação estratégica) Tornam-se claras, aí, a necessidade e a força dos processos comunicacionais na construção social.

O capítulo que observamos mostra, com clareza, o dispositivo em construção como ponto nodal para viabilização da circulação pretendida entre os dois tipos de parceiros - pois busca sua constituição no vão livre entre um e outro circuito. Aparentemente, a tentativa dos participantes comunitários é a obtenção de produtos audiovisuais de boa qualidade direcionados para seus objetivos de ação social (formação, informação, divulgação e base para interações interpretativa e de aplicação) - e ainda "incluir nossas pautas na grade das programações”, como diz um entrevistado, na pesquisa referida. Aparece já aí, com clareza, a pista dupla na autoestrada em construção: os programas (vídeos, maletas) "descem" de montante a jusante; paralelamente, a pauta dos grupos comunitários, "sobe" das ações de campo, não só para a geração de audiovisuais, mas também (quem sabe sobretudo) para a própria cultura dos produtores midiáticos, como temas tornados perceptíveis e legítimos.

A partir do outro ponto de vista, se o canal fornece produtos, tem a expectativa de receber uma espécie de assessoria indireta mas substancial sobre "o que faz sentido" para os usuários - assumindo que os "grupos de referência" representam, para além de seu próprio círculo, o ângulo certo para ingresso dos temas em setores sociais mais abrangentes - escolas, hospitais, outros grupos comunitários, setores de ação social e em geral, na sociedade, todo um público interessado nas questões tratadas. $\mathrm{O}$ que segue adiante é o produto; o que retorna são, ou devem ser, informações sobre sintonias possíveis de interlocução.

Naturalmente, dado o modo tentativo inevitável na geração de quaisquer dispositivos e circuitos experimentais, nem tudo se passa em modo fluente. Em cada campo, os processos mesmo de 
circulação não são os habituais e frequentemente não se conformam às expectativas do outro parceiro - o capítulo o mostra. Mas é daí mesmo que se espera um processo lento de ultrapassagem dos limites, ainda que na forma de aprendizagem do erro.

O desafio dos dispositivos experimentais é o de exigir - e de tornar explícito, entre os participantes - um desenvolvimento das competências de escuta e de negociação. 


\section{0 noticiador-noticiado}

Ana Lúcia Medeiros

\section{Introdução}

Na sociedade atual observa-se a celebrização de personagens que ganham visibilidade a partir de aparições constantes em programas de televisão, revistas, colunas de jornais, sites, além de blogs e tweets. Há uma proliferação de informações que são criadas em torno do universo particular de personagens e são replicadas, sem que necessariamente haja uma apuração atenta dos fatos.

Tais informações sobre aspectos privados de personagens públicas ou mesmo inicialmente anônimas geram um mercado de publicações de grande intensidade. Na sociedade em midiatização, determinadas pessoas, como artistas, atletas, políticos e modelos, por razões diversas, são reconhecidas em espaços públicos e provocam um interesse difuso em diferentes circuitos. Essas pessoas ganham visibilidade por terem realizado algo relevante ou mesmo que nada de extraordinário tenham feito. Elas simplesmente estão em evidência em circunstâncias específicas, muitas vezes de forma banal. Por outro lado, os próprios processos midiáticos crescem em várias direções, estimulam essa difusão. Por fim, o público consome e, ao mesmo tempo, retroalimenta a mídia com esse perfil de informações gerando ou estimulando circuitos sociais de interação.

Embora possamos compreender que celebridades são integrantes de um sistema midiático, com algum grau de visibilidade, 
uma proposição de Bauman sugere que não temos condições de estabelecer um sentido que possa expressar, com validade universal, um conceito para "celebridade":

[...] a história da longa marcha dos mártires às celebridades não deve ser vista como uma afirmação das leis inquestionáveis da história e de sua tendência irreversível, [...] mas como uma avaliação de carreira de um processo que está longe de haver terminado e que pode ser considerado muito mais in statu nascendi (Bauman, 2007, p. 70).

$\mathrm{Na}$ ausência de "leis inquestionáveis", se queremos compreender um fenômeno, devemos observar seu contexto específico na sociedade em midiatização. Classificamos como "celebridades" as pessoas que aparecem constantemente na mídia, seja para tratar de aspectos relacionados a sua profissão ou por circunstâncias variadas que as tornam pessoalmente famosas.

\section{Da celebrização generalizada ao noticiador-noticiado}

Da celebrização diversificada na mídia, ingressamos no estudo dos jornalistas, que se tornam às vezes famosos, apresentando algumas semelhanças - mas também diferenças - com as demais celebridades, no que se refere à formação de imagem junto ao público e a um noticiamento amplificado.

Jornalista é um profissional especializado da mídia, o que implica uma relação diferenciada no que diz respeito aos demais personagens celebrizados. O jornalista se apagaria ante a objetividade da informação apresentada. Por isso mesmo, se distingue de modo intrigante nesta condição particular de ser, ele mesmo, notícia.

Essa articulação paradoxal, alguém ser jornalista e ser notícia, incide sobre o próprio processo produtivo jornalístico de modos 
distintos - que variam de acordo com os perfis diversificados dos jornalistas, as relações estabelecidas com seus circuitos de interação (internautas, telespectadores, leitores, radiouvintes), o contexto social, as empresas das quais fazem parte. Cada jornalista, quando nessa condição, reage de uma maneira aos processos da fama. Também verificamos que não há um modo de reação uníssono da sociedade a essa situação estranha da visibilidade adquirida pelo jornalista.

É essa situação específica do aparecimento do noticiador-noticiado que investigamos, em distinção aos artistas e outros perfis de celebrização: há especificidades na celebrização de jornalistas em relação a outros tipos de personagens celebrizados. Embora com distinção de perfis, jornalistas são profissionais da notícia e a ela estão vinculados. Quando o jornalista é notícia - logo, reconhecido, percebido em sua singularidade pessoal, em suas atitudes, quando se torna famoso, é observado em suas decisões privadas, em suas posições diante da vida - é acreditado, possui credibilidade porque seus circuitos de interação o aceitam como pessoalmente confiável. Porque não faz as coisas como qualquer outro faria.

É nessa particularidade que os processos ocorrem. Há movimentos específicos; existem diferenças comunicacionais (de circuitos, de processualidade interacional) com os espectadores. Os circuitos de recepção, de absorção da notícia; os modos de produzir e de processar a notícia são então mais complexos, pois envolvem duas processualidades básicas - a do padrão de objetividade, com todas as suas regras, padrões, deontologia profissional, dos manuais de redação; e a do padrão de pessoalidade celebrada. Essa dinâmica que evidencia as diferenças e singularidades dos processos deixa claro que se deve evitar uma generalização, pois nem todo trabalho jornalístico passa a funcionar segundo tais lógicas.

Compreendemos então como noticiador-noticiado o jornalista que adquire visibilidade midiática, incluindo aí todos os modos 
de aparecimento na mídia e não só quando se trata propriamente de "ser notícia", em sentido jornalístico estrito.

Há maneiras variadas de o jornalista colocar-se na matéria, desvelar os modos de produção ao mesmo tempo em que se apresenta como parte do processo. E é nessa aparição pessoalizada que identificamos os diferentes perfis de profissionais que são destaque na mídia. São formas diversificadas de aparecimento. Essas especificidades se manifestam na maneira como as celebridades se relacionam com seus celebradores, quando são abordadas na rua, em situações que caracterizam a exaltação de personagens públicas.

A TV tem uma dimensão autorreferencial na performance midiática das personagens públicas, mas a internet passa a integrar o sistema e funciona como complemento à TV. A televisão pauta a internet, que pauta a revista, que pauta o jornal, que pauta o rádio, que pauta a televisão, que pauta o site, que recebe respostas dos internautas a respeito do que está em exposição na mídia. Tudo isso modifica os circuitos habituais e viabiliza novos circuitos.

As lógicas se mantêm e se modificam. O movimento circular em torno do jornalista, o aparecimento dos bastidores, os modos de produção se manifestam de maneira intensa. Isso faz parte de uma tendência generalizada de mostrar processos e de gerar movimentos que levam ao aparecimento do profissional do jornalismo, e este passa a integrar um modo de funcionamento normalmente aplicado ao universo dos artistas. Desenvolvem-se aí circuitos diversificados (ver Braga, 2012c). A presença do jornalista de TV em mídias variadas passa a integrar outros processos de circulação com os públicos que participam interacionalmente do processo.

Os circuitos de interação são estabelecidos de diversas formas. Por cartas, emails, telefonemas ou pelas redes sociais. Outro tipo de diversificação de circuitos se manifesta quando pessoas públicas 
fazem algum tipo de declaração na mídia ou fazem algum comentário no twitter ou no blog pessoal sobre um jornalista.

O jornalista tem papel importante no processo. Observamos que, em muitas circunstâncias, a visibilidade é provocada pelo próprio profissional do jornalismo. Trata-se de um processo tentativo no qual o jornalista utiliza ferramentas e recursos do universo do qual faz parte e assume a função de provocar os seus circuitos de interação exaltando a própria imagem.

\section{Casos específicos}

Para observar o processo que leva o noticiador à condição de noticiado, entrevistamos diversos jornalistas ${ }^{95}$. Exploramos no conjunto de informações e em cada caso os ângulos aqui referenciados. Descrevemos episódios em seus aspectos mais gerais e relevantes para especificar as singularidades dos entrevistados. São episódios distintos, que evidenciam uma construção e um exercício tentativo da fama - não existem fórmulas gerais padronizadas. Para o presente capítulo, selecionamos quatro dos casos estudados na tese. Interessa-nos perceber, em cada caso, de que modo ocorrem os processos de interação, as lógicas e ações internas e externas presentes nos episódios relacionados ao processo de circulação, em cujo cenário instalam-se novas "formas de contato" (Fausto Neto, 2007c).

\section{Episódio Rachel Sheherazade: a opinião pessoal polêmica}

A partir da leitura de um comentário polêmico em uma TV local de João Pessoa, distante do eixo Rio São Paulo/Brasília, um

95 Acionamos, para esse capítulo, um subconjunto de entrevistas realizadas para nossa tese de doutoramento (Medeiros Batista, Ana Lúcia, 2013) 
milhão de internautas acessaram o vídeo postado no youtube no qual a jornalista questiona o formato do carnaval nordestino, emitindo opiniões estritamente pessoais. Vemos aí uma situação que sublinha a importância de refletir sobre a objetividade jornalística. Tradicionalmente associada ao distanciamento necessário do jornalista em relação à notícia, a objetividade jornalística propõe a isenção e um distanciamento do jornalista para uma fiel reprodução dos fatos como eles se apresentam na realidade. A objetividade dos fatos pede o apagamento do jornalista; se contrapõe à ideia de subjetividade jornalística, que permite que o sujeito conte e mostre como a realidade se apresenta e que ele próprio se manifeste diante do fato.

A informação sobre a repercussão do vídeo chegou à direção da emissora SBT, em São Paulo. A interferência dos internautas fez com que a jornalista fosse promovida âncora do telejornal de horário nobre da emissora, em rede. Isso mostra uma escolha de interlocução. Entre o padrão de jornalismo objetivo e informador e o circuito de acolhimento, na internet, da opinião pessoal relacionada à notícia, a emissora resolve apostar nesse circuito.

A pesquisadora Caroline Casali identifica no caso Sheherazade um circuito que vem de acontecimentos motivados por uma réplica social que provoca mudanças nas bases do jornalismo: "o fluxo de uma réplica social acabou interferindo nas posições hierárquicas dentro da redação jornalística do SBT". [...] "A réplica social acaba coproduzindo um acontecimento. Esse acontecimento é autorreferencial para o próprio jornalismo e altera os padrões que nós tínhamos em jornalismo até aqui” (Casali, 2012).

Observamos no caso Rachel Sheherazade circuitos que vêm das manifestações de identificação ou repulsa às posições ideológicas da jornalista no espaço do telejornal. Os circuitos ocorrem em duas perspectivas: de um lado, internautas, leitores, telespectadores, 
que assumem o papel de movimentar as redes sociais com comentários e reprodução do que foi dito por Sheherazade. A maior parte dos seguidores do twitter ou dos que emitem opinião no blog pessoal da jornalista fazem manifestações de apoio. Mas há também críticas veementes. Do outro lado estão as empresas de comunicação e formadores de opinião, que partilham ou repercutem negativamente as opiniões de Rachel Sheherazade.

Podemos observar, no caso, a diversidade de circuitos que se manifestam quando pessoas públicas fazem algum tipo de declaração na mídia ou postam um comentário no twitter ou no blog pessoal. Em vários espaços midiáticos são feitas replicações sobre as opiniões de Sheherazade. Selecionamos dois episódios de repercussões polêmicas sobre suas opiniões.

No primeiro episódio, logo depois que a âncora do SBT repudiou a atitude de alguns manifestantes que quebraram ônibus durante protestos contra o aumento da passagem do transporte coletivo em São Paulo ${ }^{96}$, a apresentadora Mônica Iozzi fez a seguinte postagem em seu twitter: "Por Deus todo poderoso, quem é essa IMBECIL REACIONÁRIA que apresenta o Jornal do SBT??!!!” (Iozzi, 2013). A crítica de Iozzi foi replicada no site Uol. Nos comentários a essa postagem ${ }^{97}$, encontramos abordagens variadas. O internauta Domingos Barbosa fez uma comparação entre Iozzi e Sheherazade: "Rachel é o que tem de melhor na televisão, enquanto a Iozzi.... Outro internauta, que se identificou como Dico, opinou sobre a situação do jornalismo: "O jornalismo perdeu seu papel: dar a notícia com imparcialidade, deixando o telespectador fazer

96 SBT Brasil, 14 de junho de 2013.

97 No período de 17/06/2013 ao início de março de 2014 foram feitos 291 comentários. http://natelinha.ne10.uol.com.br/noticias/2013/06/17/monica-iozzi-critica-rachel-sheherazade-imbecil-reacionaria-62573.php Acessado em 02 de março de 2014. 
seu próprio julgamento. Por isso tantas polêmicas. É somente dar a notícia. Esse é o papel do jornalismo".

$\mathrm{O}$ outro episódio rendeu grande embate polêmico. Ocorreu em fevereiro de 2014, quando a jornalista defendeu "cidadãos" (justiceiros) que espancaram e amarraram a um poste um adolescente suspeito de furto no Rio de Janeiro. Sites como Uol e R7, o Jornal da Band, a Folha de S. Paulo e as revistas Carta Capital e Veja cederam espaço para repercutir as declarações de Sheherazade. Blogs e tweets também fizeram ecoar a proposição da jornalista.

O Portal Imprensa deu ênfase à nota de repúdio do Sindicato dos Jornalistas do Rio de Janeiro à sentença de Rachel Sheherazade sobre o "marginalzinho" preso ao poste. A entidade considera a declaração da jornalista uma "grave violação aos direitos humanos e ao Código de Ética dos Jornalistas". O site Congresso em Foco publicou matéria sobre denúncia de um partido político ao Ministério Público contra Sheherazade e o SBT pelos pronunciamentos da jornalista.

A repercussão do episódio em espaços variados da mídia e da sociedade estimula a criação de circuitos em que se elaboram respostas e, certamente, provocam incidências nas bases do jornalismo e em seus vínculos hierárquicos com a empresa, suas lógicas e ações. A partir de abril de 2014, Sheherazade passou a transmitir a notícia no SBT Brasil sem fazer comentários.

Identificamos no caso Rachel Sheherazade circuitos que revelam a imbricação cada vez mais intensa dos espaços midiáticos com a sociedade. Percebemos uma circulação ampliada, acionando diversos processos com variedade de sequências: emissora de TV; pessoa pública; embate polêmico em espaços midiáticos variados - jornal impresso, revistas, sites de perfis variados, outras emissoras de TV; leitores, telespectadores, poder público, redes sociais; emissora de TV. 


\section{Caco Barcellos: os bastidores da notícia são a pauta}

O jornalista Caco Barcellos abre as portas do programa "Profissão Repórter" para o processo jornalístico e se torna notícia ao falar da produção da notícia. A presença de um jornalista diante das câmeras para falar do processo de produção ocorre também em outros produtos da televisão. No caso do Profissão Repórter ${ }^{98}$, a interação se dá ao ser mostrada a apuração, no próprio ato da construção da notícia, provocando um efeito de transparência no processo produtivo.

Esse efeito de transparência da produção, que se manifesta na mostração de bastidores, gera credibilidade. Esse critério, de grande relevância no universo jornalístico ${ }^{99}$, é reforçado por informações sobre as rotinas produtivas. Se o jornalista passa credibilidade no momento em que expõe os bastidores da notícia - uma das características do programa Profissão Repórter, que tem à frente o jornalista Caco Barcellos - as informações que transmite revelam ainda mais o sentido de realidade.

No que diz respeito aos aspectos bastidores e credibilidade, Paula Melo, na análise do texto apresentado no Seminário D\&C, enfatiza que "a transparência da produção [os bastidores] passa a ser fator importante na manutenção da credibilidade junto ao telespectador" (Melo, 2012).

98 Concebido e dirigido por Caco Barcellos, o programa estreou em 2006, aos domingos, no Fantástico. Antes havia sido exibido no Globo Repórter, como edição especial. Profissão Repórter conta com uma equipe de jornalistas recém-formados, que ganham o reforço de editores mais experientes da emissora. Tem como característica revelar os bastidores da notícia, mostrando ao telespectador o processo de produção da reportagem. É exibido pela Rede Globo, às terças-feiras, às 23h30, com duração média de 30 minutos.

99 Para Berger (1996), a credibilidade é o capital do campo jornalístico. 
A ação de levar os bastidores do jornalismo ao público, que vem sendo adotada como prática, representa um movimento que revela novos dados na relação entre a produção jornalística e seus públicos. O que, no jornalismo canônico, é feito de modo discreto, quase com pudor, hoje é compartilhado com os telespectadores. $\mathrm{O}$ aspecto bastidores está, portanto, associado a um movimento de aproximação com os públicos. Isso cria verossimilhança, ao mesmo tempo em que remete a novos espaços de publicização da rotina produtiva jornalística em espaços variados, o que pode representar aumento da audiência para os telejornais, já que os assuntos são postos em discussão. Por outro lado, atrai internautas, leitores de revistas e jornais e telespectadores interessados nos telejornais.

O que se percebe, aí, é um circuito crescentemente ativado na sociedade em midiatização. Já não se trata apenas de "receber notícias", torna-se relevante desenvolver competências sobre o próprio processo de produção da notícia (ver Braga, 2007). A sociedade - pelo menos sua parte mais atenta e reflexiva - se preocupa em apreender processos, em compreender dimensões que são trabalhadas na construção, no processamento e difusão das ocorrências. Isso indica um circuito mais analítico e potencialmente crítico sobre o que as empresas de comunicação fazem circular. $\mathrm{O}$ fato de um jornalista organizar de tal modo esse acompanhamento, no "Profissão Repórter", torna a própria produção objeto de notícia gerando esse efeito crítico-pedagógico. O noticiamento do noticiador é diferenciado. Não se trata de uma fama superficial ou meramente pessoal - mas uma apreciação que vai ao núcleo do próprio entendimento dos processos jornalísticos. É um ângulo em que o jornalista interage com circuitos sociais muito especificados. 


\section{Rosana Jatobá: 1 min42s de vida pessoal no Jornal Nacional}

Um diálogo aparentemente espontâneo mantido pelo período de mais de um minuto no telejornal de horário de maior audiência da televisão brasileira me chamou a atenção. A "chamada" (termo técnico utilizado para fazer referência ao texto lido pelos apresentadores na introdução da reportagem) para a previsão do tempo do dia 3 de novembro de 2010 do Jornal Nacional da Rede Globo transformou-se em um fato inusitado.

Ao chamar a jornalista responsável pelas informações sobre a meteorologia, os apresentadores Fátima Bernardes e William Bonner fizeram uma abordagem diferente. Adotaram um jogo de palavras para fazer referência ao tempo restante para o nascimento dos filhos da repórter, grávida de gêmeos.

A situação aponta para o aparente paradoxo do "noticiadornoticiado" que, pela tradição, para ser "objetivo", se manteria como figura distanciada.

Segundo me relatou em entrevista, Rosana Jatobá havia sido alertada pela produção que, naquela noite, falaria no Jornal Nacional sobre sua gestação. Mas a abordagem a ser dada pelos apresentadores não havia sido previamente detalhada pela produção. Embora tenha sido dito que tudo aconteceria em clima de informalidade (num espaço que tem como característica a formalidade).

Os apresentadores Fátima Bernardes e William Bonner conversaram com a jornalista sobre a gravidez, antes de tratarem do assunto que Rosana Jatobá abordaria: a meteorologia. Com as mãos sobre a barriga, acariciando-a, a "moça do tempo" (uma referência à profissional que apresenta o quadro sobre previsão do tempo) anunciou a chegada dos gêmeos para o mês de janeiro.

É Fátima Bernardes quem assume o comando da entrevista. Além de abrir o diálogo, a apresentadora faz quatro perguntas a 
Rosana Jatobá, contra um rápido comentário do apresentador e dois momentos de um sorriso contido, respeitoso e de aprovação à gravidez e ao diálogo entre as jornalistas sobre a história pessoal da "moça do tempo" no espaço do telejornal.

Sendo gravidez o assunto em pauta, caberia às mulheres abordar a questão. São hábitos culturais que geram audiência e sintonia com o telespectador. Há aí um efeito de proximidade. Por outro lado, o diálogo intensifica a força da mulher profissional e, ao mesmo tempo, dedicada à maternidade, traço de um modo de vida da mulher brasileira da sociedade contemporânea.

$\mathrm{Na}$ frase "mas a pergunta que nós, os telespectadores, gostaríamos de fazer pra você...”, a apresentadora assume o papel de representante das pessoas que assistem ao telejornal. Essa condição é reforçada pela repórter: "Olha, todo mundo tá muito curioso para saber". Observamos aqui uma tentativa de aproximação com um público do telejornal, tanto no que diz respeito ao assunto (maternidade) quanto no interesse pelos profissionais que levam a notícia diariamente à casa do telespectador. Entram nesse item aspectos como fidelidade, cumplicidade e até mesmo uma certa intimidade com os jornalistas, para os quais muitos telespectadores respondem "boa noite".

Como se vê, aposta-se aqui (com sucesso de público) em outro processo de circulação. Trata-se agora de uma curiosidade sobre a vida pessoal de profissionais que se destacam simplesmente porque são vistos. Há significativas parcelas da população que veem nas matérias não uma técnica de passagem de informações, não um serviço de natureza pública. Ou não apenas isso. Ao lado e através, esse espectador vê pessoas. Quem são, o que fazem, como se articulam com "gente do comum"? O perfil é bem diferente dos que querem ver circulando informações de fundo sobre como se produz a informação. O que aparece, no caso, é apenas um ângulo de identificação 
pessoal - uma mulher que está grávida. Mistura-se, no episódio, o fato profissional, de ordem pública, com o fato de ordem privada. O próprio âncora dá a pista do circuito que se manifesta e ao qual a TV (claramente em busca de audiência) responde: internautas se perguntam sobre a gravidez da moça do tempo. É a oportunidade de a empresa tentar (como é da lógica da grande mídia) interagir com o imponderável social que aí toma forma. Obedecendo ao circuito, vaise oferecer o que este quer: nossa profissional sob o aspecto "gente". Completa-se, na oferta, o circuito da expectativa. De curto alcance, é claro - mas o suficiente para que percebamos fluxos de interação que se abrem na sociedade e pedem resposta e alimento.

\section{Tadeu Schmidt: coprodução com espectadores provoca efeito de proximidade}

Nascido em Brasília, Tadeu Schmidt tem obtido posição de destaque no telejornalismo nacional. Uma das características do trabalho que desenvolve é experimentar no vídeo situações do cotidiano que considera passíveis de adaptação para o jornalismo esportivo, sua especialidade.

Vem exercendo essa prática em todos os espaços ocupados ao longo da trajetória na Rede Globo. Tem o apoio da empresa, representada pelos editores-chefes. $\mathrm{O}$ resultado das experiências de Tadeu Schmidt vai além da Redação dos telejornais. Os telespectadores passaram a interagir com Schmidt, em situações variadas, que vão das respostas pela internet à abordagem nos espaços públicos, utilizando expressões que o jornalista adota na produção do trabalho de construção da notícia. O processo de experimentação de Schmidt avança à medida que ascende profissionalmente dentro da empresa. Continua a experienciar na produção do jornalismo televisual o uso de jeitos e falas da vida cotidiana. 
Uma das inovações de Tadeu Schmidt no telejornalismo é aproximação com telespectadores/internautas de várias regiões do país. São os aficionados por futebol que capturam os lances mais originais nos estádios de futebol de cidades quase sempre ausentes da escala da produção jornalística. As imagens feitas dos celulares e câmeras pessoais dos telespectadores/internautas são selecionadas por editores locais e enviadas a Tadeu Schmidt que, num estilo pessoal de fazer jornalístico, faz a fusão de lances bem-humorados e criativos de produtores-colaboradores que, mostrando cenas de habilidade ou não com a bola, em jogadas de futebol doméstico, alimentam o quadro Bola Cheia e Bola Murcha, crônica esportiva de Schmidt no programa Fantástico, da Rede Globo ${ }^{100}$, onde assume também o papel de apresentador.

O jornalista José Cruz nos disse, durante o levantamento de dados para a tese de doutoramento, que os princípios norteadores do jornalismo são respeitados por Tadeu Schmidt; mas o trabalho jornalístico que exerce traz a sua pessoalidade:

Ele executa todo o processo de apuração, edição e apresentação da notícia. $\mathrm{O}$ diferencial é que coloca a sua marca e usa a tecnologia para tornar a informação mais leve. Ele prende o telespectador com as imagens das quais dispõe e utiliza um vocabulário criativo e adequado àquelas imagens. E surpreende, sempre, ao desviar o foco do gol para trabalhar personagens, fatos paralelos.

100 Conhecido como "revista eletrônica", o Fantástico vai ao ar nas noites de domingo, desde 1973. 
Cruz $^{101}$ afirma que Schmidt sabe aproveitar os recursos técnicos que tem a seu dispor, mas também procura desenvolver um trabalho de valorização de elementos nucleares do jornalismo ao fazer uma apuração com pluralidade de dados:

Tadeu é para a crônica esportiva na TV o que Nelson Rodrigues foi para o jornalismo impresso: inovador. Nelson é insuperável, conquistava o leitor apenas pelo texto. Prendia até o fim. Tadeu tem a vantagem de dispor da imagem, da cor e do movimento, além da informação diversificada com a qual pode trabalhar. Juntou tudo isso e inovou numa época de mesmices no relato sobre esportes. Ele explora bem o lado inusitado da informação. Tem a capacidade de pegar imagens de um "gol de cabeça" realizado em lugares extremos do país e exibir, em um programa transmitido nacionalmente, algo que poderia ficar restrito às regiões de pouca representatividade nacional (Cruz, 2013).

Observamos nessa dinâmica que a empresa percebe o potencial da sociedade na captura de imagens e informações sobre o fato, não facilmente percebidas ou alcançáveis pela equipe de TV ao fazer a cobertura de um evento. A sociedade, por sua vez, reconhece a visibilidade proporcionada pela televisão e participa do processo produtivo. Aparecer na televisão pode funcionar como uma recompensa pelo trabalho colaborativo. Com isso, a sociedade participa de modo mais ativo da produção midiática e da difusão de informações mais coerentes com as culturas locais. É o espectador, estimulado pela empresa, que mostra as cenas que integram o Bola Cheia e Bola Murcha, do programa Fantástico.

101 Dono do "Blog do Cruz", José Cruz levou para o blog sobre política e atualidades no esporte a experiência de 28 anos de atuação no jornalismo impresso. 
Percebe-se nesse movimento a construção de um circuito como um processo interacional em que cada tipo de participante reage a uma provocação e oferece falas, que por sua vez são retomadas fazendo o circuito se manter em funcionamento (ver Braga, 2012c).

Identificamos ainda, neste caso, a perspectiva de que a interlocução assim encaminhada faz substituir o "jornalista informador" por um jornalista participante de interação que, para fazer parte do circuito, é levado a reagir, a responder - e com isso, por sua vez, estimula a produção e a interação do espectador. Fazem parte desse circuito o diálogo com o internauta/telespectador/produtor no próprio espaço do telejornal e também nas relações mantidas por outros modos de interlocução estabelecidos no processo de captura e entrega do material produzido, dando continuidade ao processo que, dinâmico, ganha novas configurações a partir de experiências feitas pelo jornalista, a produção da TV e os espectadores/ colaboradores.

No que diz respeito à experimentação do jornalista no exercício da profissão, percebemos que ele desenvolve procedimentos para adequar à linguagem formal do jornalismo elementos do seu cotidiano, de sua visão de mundo, de sua vivência com o futebol, das torcidas organizadas entre amigos para ver um jogo, seja em Brasília (onde cresceu, vivendo o universo esportivo) ou no Rio de Janeiro (para onde foi transferido ao obter ascensão profissional). Além de compor sua produção jornalística com características pessoais, acordou com a empresa que a sociedade tem um papel importante na construção de um produto informativo. Os participantes sociais, por sua vez, estabelecem um vínculo com a empresa e, de modo mais específico, com a pessoa do jornalista, para quem também enviam mensagens pela Central de Atendimento ao Telespectador ou por outros meios de manutenção de um processo interacional, 
como o site da emissora. No processo de interação do jornalista com os participantes sociais do circuito, tornam-se então inseparáveis o papel profissional jornalístico, os aspectos pessoalizados de sua participação e os vínculos com o programa e a empresa. Essa parece ser a lógica que dinamiza o circuito aí explicitado.

\section{Que circuitos estão sendo testados aí?}

Os circuitos do noticiador-noticiado se manifestam de modos diversificados, assim como os perfis dos jornalistas que selecionamos para entrevistar. Os processos ocorrem a partir de lógicas que alimentam um sistema transformador, experimental, de práticas pouco habituais. São movimentos que contemplam modos de funcionamento preexistentes, mas principalmente compreendem novas experimentações, processos interacionais, de circulação, novas "formas de contato" (Fausto Neto, 2007c). Processos nos quais modelos canônicos são reformulados, provocando novas dinâmicas que apontam para uma realidade que está sendo tentativamente construída.

Retomando a citação de Bauman, sobre a inexistência, em nosso tema, de "leis inquestionáveis da história e de suas tendências irreversíveis" (2007, p. 70), se queremos compreender que circuitos estão se desenvolvendo nos casos analisados, devemos observar o contexto específico de uma sociedade em midiatização, cujos processos midiáticos crescem em várias direções e ocorrem de forma difusa e canhestra.

A televisão, no período de forte centralidade dos meios de massa, decidia isoladamente seus processos e podia então assumir "seu circuito" - comandado exclusivamente por suas lógicas midiáticas. Hoje, em período de midiatização social, os circuitos proliferam e são originados também em outros espaços. As 
empresas de TV buscam capturar esses circuitos segundo seus interesses e perspectivas. No âmbito que observamos, a formação da fama pela visibilidade é uma tradição da televisão. $\mathrm{O}$ específico que estudamos aqui é a diversificação dos processos.

Através das entrevistas, identificamos movimentos variados, conforme a diversidade de perfis e das experiências distintas. Verificamos, em alguns casos, a participação do próprio jornalista no processo de alimentação dos circuitos de interação.

Nos casos observados dos noticiadores que são noticiados, há ângulos diferenciados de noticiamento, que ultrapassam uma fama superficial ou pessoal, indo ao núcleo dos processos jornalísticos. O jornalista interage com circuitos sociais específicos. É o que verificamos com Caco Barcellos, no programa Profissão Repórter, em interlocução com circuitos que têm a perspectiva de transformação social, numa fusão de mostração dos bastidores da produção noticiosa com a realidade social noticiada, em um processo de mutação do jornalismo e da sociedade. São processos experimentais que dão visibilidade àquilo que normalmente fica por trás da câmera, onde ocorrem os processos tentativos.

Caco Barcellos, ao fornecer dados relacionados à sua rotina produtiva, num movimento de exposição de bastidores, provoca um efeito de transparência e ganha a confiança do espectador, especialmente porque no tipo de reportagens que o Profissão Repórter produz, de jornalismo investigativo, Barcellos se diferencia por fazer um rigoroso trabalho de apuração não-sensacionalista, mas de observação atenta dos fatos, numa dinâmica que preserva a imagem das personagens envolvidas e valoriza o trabalho e a pessoa do próprio jornalista que produz a reportagem.

Outros processos são excessivamente simples ou de curto alcance - como no caso da pessoalização de uma circunstância de vida privada, noticiada em um telejornal de horário nobre, como 
destacamos no caso Rosana Jatobá, cuja história pessoal ocupou mais de um minuto do Jornal Nacional. Trata-se de uma situação que alimenta a curiosidade em setores do público, motivados a obter informações sobre "gente". Sem entrar em uma crítica sobre esse atendimento, o que observamos é que ele se esgota por si mesmo, ao atender a uma curiosidade de superfície, algo também presente na sociedade contemporânea, que tem a tendência a inventar heróis e mitos midiáticos.

Outros processos representam tentativas ainda muito canhestras, exigindo ajustes, ponderações, reprocessamentos, até que se encontrem graus pertinentes e com valor social significativo de equilíbrio entre informação objetiva, análise judiciosa dos fatos e emissão de opiniões pessoais (que certamente podem ter seu valor). $\mathrm{O}$ caso Rachel Sheherazade mostra as lacunas a serem ainda supridas para que tais circulações se tornem um processo tentativo pertinente como experimentação de sociedade e de relações com a mídia.

Percebe-se também uma dinâmica de autopromoção, como no caso de Rosana Jatobá, ao escrever em seu blog um artigo sobre o noticiamento de sua gravidez no Jornal Nacional. No caso Sheherazade, ela mesma repercute os rumos dados à sua vida pessoal e à sua trajetória profissional a partir da postagem no youtube do comentário polêmico sobre o carnaval nordestino. Tendo constatado o processo transformador e de visibilidade adquirida, deu continuidade ao modelo polêmico experimentado.

Em outros processos de experimentação, a mídia faz um claro apelo de coprodução à sociedade, reconhecendo a importância desta na reinvenção dos modos de fazer midiáticos. O processo é tentativo e circular, no sentido de que busca nos espectadores a participação ativa, o que permite uma interação mais intensa entre os circuitos de recepção e produção, com erros e acertos que, embora 
em processos às vezes canhestros, amplia os vínculos interacionais entre jornalistas e espectadores. É o que verificamos no caso Tadeu Schmidt no processo de produção do Bola Cheia e Bola Murcha.

Nos casos analisados, apesar das singularidades que se evidenciam em cada noticiador noticiado, constata-se, é claro, o foco da empresa em busca de audiência. Nessa perspectiva, identificamos que as particularidades de cada profissional são percebidas como passíveis de atrair tipos específicos de público. Em todos os casos, prevalece a especificidade do trabalho jornalístico. São profissionais do jornalismo e, portanto, seguem os princípios norteadores do trabalho jornalístico. Mas, justamente em função das transformações observáveis na sociedade em midiatização, prevalece, em cada caso, um modo de aparecer e de gerar circuitos. Há circuitos alimentados pelo aspecto "gente"; outros pela transparência dos processos produtivos; outros ainda pelo fluxo de interação que se estabelece com a empresa e com o profissional mesmo; ou ainda por características pessoais como a decisão de emitir opiniões polêmicas (de acordo com lógicas e ações hierárquicas). Em todos os casos a imagem do profissional se evidencia, a sociedade dá e exige respostas. E a empresa permanece em busca do controle garantidor da audiência, que por sua vez se encarrega de produzir novos circuitos nos blogs, tweets, sites, emails, telefonemas, produções de vídeos em seus celulares e câmeras...

\section{Material coletado na mídia}

Blog do José Cruz. http://blogdocruz.blog.uol.com.br/

Congresso em foco: "Caso Sheherazade: 'liberdade de imprensa não inclui incitação a crime', diz Janot”. http://congressoemfoco.uol.com.br/noticias/ 
caso-sheherazade-liberdade-de-imprensa-nao-inclui-incitacao-acrime-diz-janot. Consultado em 04 de abril de 2014.

IOZZI, Mônica. http://natelinha.ne10.uol.com.br/ noticias/2013/06/17/monica-iozzi-critica-rachel-sheherazade-imbecil-reacionaria-62573.php. Consultado em 18 de junho 2013.

Portal Imprensa. "Sindicato dos Jornalistas repudia declaração de Rachel Sheherazade sobre 'marginalzinho”. Portal Imprensa, Jornalismo e Comunicação na Web.

http://www.portalimprensa.com.br/noticias/ultimas_noticias/ 63790/sindicato+dos+jornalistas+repudia+declaracao+de+rachel+sheherazade+sobre+marginalzinho. Consultado em $02 \mathrm{de}$ fevereiro de 2014.

SHEHERAZADE, Rachel. Comentário no SBT Brasil, 14 de junho de 2013.

\section{Entrevistas}

Dentre as entrevistas feitas em 2012, para a tese de doutoramento "Noticiador-noticiado: Perfis de jornalistas numa sociedade em midiatização", foram aproveitadas para o presente estudo: Rachel Sheherazade, Caco Barcellos, Rosana Jatobá e Tadeu Schmidt. 


\title{
Suíte n ${ }^{0} 6$
}

\section{“O noticiador-noticiado", de Ana Lúcia Medeiros}

\author{
José Luiz Braga
}

A questão interacional genérica, que é o ponto de partida de Ana Lúcia, refere-se ao processo de celebrização de pessoas que obtém certa visibilidade na grande mídia. As imagens construídas e tudo o que diz respeito a essas pessoas circula intensamente, produz adesões (e, eventualmente, correlatas repulsas), preferências, alinhamentos, adoção de personagens como modelos. Nas análises acadêmicas desse quadro geral, bastante estudado, aparecem desde críticas à espetacularização até esforços de explicar sociologicamente o fenômeno, seus processos e seus personagens.

Dentro desse tema recorrente, o estudo de Ana Lúcia Medeiros recorta uma preocupação mais específica, que permite evitar explicações prontas abrangentes, que fariam de casos singulares meros exemplos de uma situação muito generalizada, e apenas confirmariam o que mais ou menos já se sabe ou se pode rotineiramente afirmar a respeito de celebridades e de celebrização. Em vez disso, a autora busca uma dupla especificação. Primeiro, trata da questão centrada no jornalista como notícia - levando a perguntas relativas à profissão: Que noticiamento é este, que desloca uma posição tradicional do trabalho jornalístico? Como este processo se relaciona com os dispositivos habituais do "fazer notícias"? Em seguida, já no âmbito dessa situação propriamente jornalística, o texto estuda quatro casos, que vão mostrar lógicas singulares, que remetem a modelos diferenciados de visibilização. 
Na perspectiva comunicacional, busca-se uma sintonia fina dos processos que caracterizam a diversidade de interações e de circuitos de ocorrência do fenômeno observado. Embora este tenha, certamente, características gerais, uma percepção das especificidades é relevante para um conhecimento dos processos, com maior acuidade que a afirmação de causalidades gerais.

Na prática mais estabelecida, a objetividade da notícia é que assegura sua credibilidade - e a credibilidade do jornalista seria decorrente justamente do rigor de uma apuração do que será afirmado como fato. Nesse padrão, uma espécie de isenção quanto a posições assumidas e opiniões divergentes faz prevalecer o valor intrínseco das matérias mais que a pessoa do jornalista. Enfatizar a factualidade da notícia, o resultado do processo de apuração, a objetividade da informação seriam os códigos básicos estabelecidos para a interação do jornalista com suas fontes e com seu público.

Tais padrões, entretanto, vão sendo ladeados por uma atenção crescente no "mensageiro". O jornalista e seus processos se tornam, na sociedade contemporânea, objeto de interesse, de atração, de variedade temática. Ou seja, em termos jornalísticos, o noticiador se torna notícia. Como este mostra sua mensagem? Como chegou ao resultado exposto? Que credibilidade adiciona à factualidade? Com que opiniões e interpretações complementa a informação?

O texto mostra, para o conjunto de casos examinados, lógicas deste tipo de interações - da circulação de personalidades na criação de uma imagem noticiada, em contraste com o distanciamento da pessoa diante do fato que esta apura e faz circular. Evidencia-se que a circulação do noticiador noticiado não pode ser banalizada, como se fosse idêntica à celebrização dos artistas, dos esportistas, ou a dos que se tornam visíveis por fortuna e sucessos pontuais.

O dispositivo "fazer notícia na TV", ao entrar em determinados circuitos, traz articulado um tema inicialmente parasitário 
- porque não era ainda muito percebido nem integrado com intencionalidade ao dispositivo original. Esse tema, meio encoberto, é a própria figura do jornalista, sua imagem, sua prosódia, a credibilidade construída aos poucos por seu estilo, ao lado da objetividade das matérias apresentadas.

Na medida em que essa circulação "suplementar" se evidencia, experiências diversas passam a ser feitas, espontânea ou calculadamente, nas emissoras. Ou seja: o aspecto aparentemente parasitário "imagem do jornalista" vai se tornando recurso possível (com bastante diversidade, como o texto de Ana Lúcia nos mostra), elemento componente do dispositivo "fazer notícia" - que, com isso, em alguns ambientes e circunstâncias, se transforma, se diversifica, gerando consequências hoje ainda na ordem da experimentação.

Uma das experiências mostrada no texto investe na atração percebida (via tendências expressas na internet) pela simples manifestação de opiniões sobre fatos noticiados. Posições conservadoras e menos habitualmente expressas na TV (talvez por receio mesmo de se evidenciarem criticáveis em um ambiente mais esclarecido) encontram uma sintonia com setores da sociedade que afinal compartilham tais ideias. A emissora percebe a potencialidade de atração de tais adesões, para a formação de seu público. Mesmo a probabilidade de opiniões contrárias não seria um grande risco para a empresa - que pode contar com outro aspecto dos processos comunicacionais: a possibilidade da interação pelo desacordo. Diante de um mesmo fato ou situação, discordar de uma opinião expressa é ainda motivo para interagir, propagar contraopiniões, e "acompanhar" o falante do qual se discorda.

Nesse tipo de episódio, a lógica interacional busca um tipo de credibilidade que nada tem a ver com a objetividade factual - e que é mesmo a contestação desta. Não se trata de um compartilhamento baseado no valor de uma opinião refletida, que fosse apoiada 
em argumentação sólida. Trata-se apenas de uma sintonia de crenças feitas. Além da mera similaridade de preferências, o processo interacional parece apostar também em uma postura de desafio a outras opiniões - uma espécie de marcação de território.

Como o texto de Ana Lúcia evidencia, a fragilidade do processo é justamente essa ausência estrutural de uma ponderação, necessária para assegurar a manutenção das opiniões em uma faixa de suportabilidade na escuta. $\mathrm{Ou}$, o que é correlato, uma ausência de antecipação das reações, na recepção, do que é afirmado, impedindo ajustes mínimos voltados para fazer a opinião transitar.

Outro dos casos mostrados por Ana Lúcia Medeiros refere-se, como a autora expressa, a "uma curiosidade sobre a vida pessoal de profissionais que se destacam simplesmente porque são vistos”. O interesse em mostrar esse episódio específico é portanto o de assinalar a percepção que o "sistema de produção" tem do interesse de espectadores pela pessoa dos jornalistas. Aliás, o ambiente mesmo em que a experiência é feita, o Jornal Nacional, já investe habitualmente nessa lógica interacional que mistura a passagem de informação jornalística com uma percepção e adesão à pessoa do informador, como busca de um adicional de credibilidade.

No caso do jornalismo esportivo, a opinião relacionada à informação não é novidade - faz mesmo parte da tradição brasileira nesse âmbito do trabalho jornalístico. Deve-se porém sublinhar que aqui não se trata de uma opinião "de cidadão" - mas sim de uma opinião que se sustenta em uma competência técnica e uma experiência prática no trato com os temas referidos.

O que parece demarcar o dispositivo de produção, interação e circulação, no caso, além do estilo do jornalista, do perfil pessoalizado específico, é o aproveitamento de recursos tecnológicos contemporâneos para desenvolver circuitos anteriores à produção de modo a obter um trabalho colaborativo, como o texto descreve. 
A diferença com relação a situações mais habituais (em que os jornalistas contam certamente com boas redes de fontes estabelecidas), é que esse circuito anterior passa a fazer parte expressamente do próprio produto.

Essa produção mostrada como processo ganha certamente uma dinâmica interacional que se transfere à circulação subsequente. Como diz Ana Lúcia, "a interlocução assim encaminhada faz substituir o 'jornalista informador' por um jornalista participante de interação que, para fazer parte do circuito, é levado a reagir, a responder - e com isso, por sua vez, estimula a produção e a interação do espectador".

O interesse ampliado do espectador não se concentra apenas na figura e na personalidade do jornalista. Depois de algumas décadas de recebimento de notícias por TV e por Rádio, de participar como receptores das notícias prontas, de se habituar aos padrões e processos das emissoras (inclusive, mas não só, pela comparação entre a diversidade de táticas destas), os espectadores passam crescentemente a se interessar por seu modo de produção. A própria profissão e seus procedimentos se tornam igualmente ângulo de interesse - e aqui, em modo nada parasitário. Os procedimentos de apuração, tratamento, seleções e formatação da notícia fazem parte desta e inevitavelmente deixam marcas no produto final.

Um círculo de interessados em debater a notícia e sua feitura se põe como circuito acolhedor para ser informado sobre os processos. Em tais circuitos se experimentam dispositivos voltados para mostrar e debater seus processos. Complementa-se a oferta de notícias prontas por informações sobre o fazer notícia.

O tipo de episódio selecionado por Ana Lúcia, dentre inúmeras experiências sobre esse ângulo de noticiamento que poderiam ser escolhidas, é um exemplo interessante, em que o jornalista, para falar sobre o processo, o faz exercendo o processo - esta parece ser 
sua lógica central. Essa lógica se compõe também de outro elemento nada secundário: a tensão dramática dos trabalhos de apuração e de edição dos fatos escolhidos para noticiar.

Assim, o dispositivo estudado, não discute conceitos abstratos de notícia, factualidade, pauta, interpretação, opinião, ética jornalística, objetividade, credibilidade, etc.; mas sim mostra tais ângulos, exercidos em casos concretos. Isso estimula um processo de familiarização com táticas e estratégias do fazer notícia, gerando no "público leigo" uma incorporação da coisa jornalística que o torna mais competente para interagir com o noticiário televisual - na dependência, é claro, dos acervos pessoais e culturais do espectador, assim como de seus contextos.

Reiteramos, enfim, os dois ângulos evidenciados pela autora nos processos interacionais estudados. Por um lado, a presença, crescentemente notada, da pessoalidade do jornalista e de seus processos de produção como elementos componentes do produto-notícia; por outro, dentro dessa "lógica articuladora", ainda experimental, uma variedade de tentativas, menos ou mais bemsucedidas, de menor ou de maior alcance - dentre as quais, a celebrização é um dos aspectos, mas nas quais se pode, também, perceber sintomas de lógicas jornalísticas de interação e de circulação, que se mostram em processo de mudança. 


\section{Jornalismo sob fluxos e ajustes: da autopercepção de editores ao processo midiático}

Pedro Benevides

\section{Introdução}

A partir de depoimentos de editores de jornais diários impressos e online de seis capitais brasileiras, um conjunto de fenômenos será sistematizado visando a apreensão de dinâmicas substanciais do processo midiático e um trajeto específico de restauração da autoridade jornalística.

O elemento empírico será articulado ao teórico: tais dinâmicas e trajeto podem ser compreendidos a partir de estudos sobre midiatização, sobretudo relacionando as noções de contrato, interfaces e fluxo contínuo, propostas por Antonio Fausto Neto desde 2006 e por José Luiz Braga desde 2007.

Este entrelaçamento de fenômenos sistematizados e estudos de midiatização segue também a orientação sobre a alternância entre formas e processos: é preciso que o observador se "desloque das fronteiras internas de um determinado 'sistema' " para transitar pelas zonas de interpenetração, segundo Fausto Neto (2010e, p. 97). Este autor, em seu projeto de pesquisa de 2010, indica o surgimento de uma "nova arquitetura comunicacional", associada a "dinâmicas de circulação" (2010c, p. 11), o que é outro modo de 
relacionar estruturação e fluxos. Esta baliza de método supõe que o estudo deve seguir um ritmo imposto pelo próprio processo midiático, que oscilaria entre agentes e flutuações, fronteiras e diluições, campos e deslocamentos, modelos e declinações, numa cadência que atravessa o processo midiático. Tal formulação atenta tanto para forças de estruturação, que fixam, sedimentam e regulam, quanto para forças de dinamização, que diluem, deslocam e fazem fluir. Assim, um ângulo de prospecção sobre o processo midiático pode ser concebido no entrecruzamento de componentes empíricos, teóricos e de método.

De abril de 2012 a maio de $2013^{102}$, foram realizadas entrevistas abertas semidirigidas (Kvale, 2011 e Valles, 2002), com editores de veículos noticiosos de empresas de comunicação em seis capitais brasileiras (conferir lista de entrevistados no final do artigo).

\section{Percepções dos editores e reações dos jornais}

Em seus depoimentos, os editores compartilham certa perplexidade em relação às iniciativas de outros agentes informativos, como um taxista que informa sobre ocorrências policiais e de trânsito pelo twitter; ou como políticos que nomeiam secretários pelas redes sociais, sem convocar coletiva de imprensa, para se dirigir diretamente ao eleitorado, e também para pressionar jornalistas a repercutirem tais decisões.

Essas mesmas iniciativas, por não contarem com o grau de especialização profissionalizada que distingue o jornal impresso diário, oferecem aos editores uma justificativa para sua existência.

102 Este artigo apresenta resultados de um estágio de pós-doutorado (de 2011 a 2014), com bolsa CNPq, realizado no âmbito do Projeto "Afetações da Midiatização sobre o Ofício Jornalístico", coordenado por Antonio Fausto Neto, na Unisinos. 
Em outras palavras, o vale-tudo da internet criaria demanda por selecionadores, filtros, editores, curadores etc., que assim ganham propósito e distinção renovados.

A informação sobre a prisão [de um deputado] foi dada em primeira mão pela dona de um restaurante. Isso era por volta das seis da manhã. Alguém viu e me ligou. (...) Quando eu entrei no twitter achando que ia ver uma pessoa falando, tinha um mundaréu. Já era. Já era notícia. Os meios de comunicação tinham dançado naquilo. (...) Ali foi um dos maiores exemplos que eu vi. A população em si se informou (...) sem mediação nenhuma, sem interferência nenhuma dos meios de comunicação (Márcio Noronha, diretor de redação dos veículos jornalísticos da Rede Diário de Comunicação, Manaus).

Existe uma tolerância muito grande com notícia que não é notícia - e depois conserta. Para o impresso, é inadmissível (Aruana Brianezi, diretora de redação do jornal $A$ Crítica, Manaus).

Eu me senti afrontado por essa decisão. (...) Anunciar secretários pelo twitter teve o objetivo de contemplar toda a energia bastante positiva que ele [governador da Paraíba, Ricardo Coutinho] obteve nas redes sociais (...) mas também eu interpretei como uma desqualificação do rito clássico da intermediação [da coletiva de imprensa] (Walter Galvão, editor-geral do Sistema Correio da Paraíba).

Quais são as fontes que têm credibilidade pra falar sobre o que está acontecendo? (...) [Há pessoas que] se aproveitam dessa realidade da internet para dizer o que bem entendem, sem as consequências que nós, empresas jornalísticas, temos [que sofrer.] (...) A empresa tem um ativo fundamental: a informação de qualidade (Carlos Alexandre, editor-geral do Correio Braziliense). 
Temos aí um leque de percepções à disposição dos editores: ora agentes externos parecem exibir capacidade informativa que desloca a exclusividade do jornal de referência, ora aqueles agentes expõem suas próprias fragilidades, que projetam a qualificação daquele tipo de jornal. Dito de outro modo, agentes informativos externos podem ser vistos como enfraquecedores ou legitimadores do jornal impresso. Dependendo das ocorrências visadas e dos interesses em jogo, as percepções podem se ajustar, oscilando do alarmismo sobre a extinção do jornal até a autoconfiança recheada de reportagens premiadas, rotativas recém-adquiridas e pesquisas atestando a credibilidade do jornal impresso diário.

Existe outro conjunto de fenômenos, envolvendo não propriamente autopercepções de editores, mas sobretudo reações concretas das empresas aos fluxos informativos externos. As organizações gradativamente se ajustam a um novo ambiente, comprometendo recursos e delegando responsabilidades específicas com a criação de funções e postos especializados, como a coordenação de mídias sociais, a elaboração de projetos especiais e a gestão de conteúdo. Depois da criação de sites jornalísticos estáticos e da passagem destes para os portais de notícias, ocorre a adesão das marcas jornalísticas às redes sociais, operacionalizando novos canais de distribuição e interação. Ao mesmo tempo, de modo informal, repórteres rotinizam seu trânsito nas redes sociais para colher informações, montar perfis e promover enquetes. A aferição de audiência passa a se capilarizar entre editores e repórteres, deixando de ser especialidade exclusiva de diretores comerciais computando tiragens, vendas e assinaturas, ou de institutos especializados de pesquisa. Os próprios jornalistas acompanham os acessos (pageviews) e postagens em suas matérias, assim como os editores monitoram os caminhos dos usuários pelo Google Analytics. 
Paralelamente a estes recursos empregados na lida com novos agentes, plataformas e circuitos, podemos encontrar a aparição de uma construção muito peculiar de sentidos e vínculos midiáticos - uma dinâmica que se convencionou chamar de viralização, e que se estende à produção de notícias. Em Campo Grande, o editor do portal de notícias Correio do Estado, Fausto Brittes, relata o seguinte episódio: um cão com leishmaniose é puxado de moto por seu dono até o Centro de Controle de Zoonoses, onde os veterinários tiram foto das suas patas sangrando e registram queixa na delegacia de animais, cuja assessoria expõe a ocorrência em seu site. Monitorando a internet, o editor replica a matéria do site da delegacia. "Confesso pra você que eu não dei muita importância. Dei um destaque, porque eu acho uma judiação fazer isso com o animalzinho". A partir desta replicação, outros sites de notícias publicam matérias similares. "De repente, no facebook, em tudo quanto era canto, começou um movimento de revolta." O cão ganha nome a partir das redes sociais, onde também surge campanha - Salve Scooby - que se torna "febre nacional", contra a posição oficial de sacrificar o animal. O jornal impresso Correio do Estado publica matéria com opiniões de especialistas. "Houve uma integração, porque a assunto também foi pra rádio, pra televisão. (...) Integrou tudo”. Finalmente, o prefeito, que já havia anunciado o sacrifício do cão, posta em seu facebook a decisão de poupar o animal (Fausto Brittes).

Neste breve conjunto de fenômenos existe uma expressiva variedade de reconhecimentos dos editores a respeito de sua relação com um fluxo diferenciado de informações. São percepções que se manifestam em diversos graus, da memória de apurações pontuais à participação em mudanças operacionais padronizadas, passando por reações imediatas e ajustes informais. A sistematização acima 
visa expor uma clivagem dos fenômenos, partindo de uma autopercepção que oscila entre incerteza e autoconfiança e que envolve uma série de reações metódicas das empresas para incorporar fluxos, incidir sobre eles e se alimentar deles. Estas reações incluem adaptações tateantes a movimentações imprevistas, que paulatinamente vão ganhando nome próprio, como a viralização. Tais impressões e reações podem ser portas de entrada para a concepção de um processo geral subjacente.

Do ponto de vista dos editores, coloca-se um trajeto de mudanças externas e ajustes internos, com novos equipamentos que se acumulam: num primeiro momento, um taxista com twitter "dava furo toda a hora - acidente aqui, assalto ali”; depois, ele começa a ajudar o jornal, ligando para a redação, que envia repórter; num terceiro passo, o jornal cria seus canais de divulgação e apuração por dentro das redes sociais, diz Marcio Noronha sobre o Diário do Amazonas.

O volume de informação que chega é gigantesco, então a gente pode selecionar muito (...). As redes sociais são o maior celeiro de pauta do mundo. (...) A redação sempre vai ter esse papel centralizador de fluxo de informação. (...) O fluxo chega muito lá dentro da redação, mas as redes sociais são uma janela para um outro fluxo, que está passando ali. A gente é um lago que está recebendo mas tem um rio passando onde temos que pescar, e aí sim dar o trato jornalístico (Márcio Noronha, Rede Diário de Comunicação, Manaus).

Gradativamente, os jornais montam uma gama de equipamentos profissionalizados para lidar com as incertezas, e o reconhecimento de empresas sobre fluxos externos vai deixando o estágio de perplexidade e atingindo um acúmulo de técnicas e instrumentos, numa capacitação para se aproveitar das dinâmicas externas de produção. Mas não há equilíbrio fixado nem instabilidade eliminada: esta pode reaparecer, como nos episódios de 
viralização, que indicam a permanência de certa autonomia de agentes e fluxos, ainda que agora estes possam ser articulados de modo mais maduro pelos grandes produtores de notícias.

Os agentes externos indicados pelos editores frequentemente aparecem como altamente voláteis e são indicados com termos genéricos ("as redes"). Ao mesmo tempo, é óbvio que o fluxo não é assim tão fluido: existem trânsitos preferenciais em algumas plataformas bem definidas, que se remanejam com a rápida ascensão de novos gigantes - sendo facebook e twitter referências obrigatórias na maioria dos depoimentos. Há uma poderosa hierarquia já instalada nos próprios fluxos destacados pelos depoimentos e as chamadas redes sociais se tornam os mediadores privilegiados entre veículos jornalísticos e os vínculos e conteúdos do fluxo online. Estes veículos se equipam ora com recursos próprios, como os portais; ora com recursos incorporados, como na atração de blogs para os portais de notícias; ora com inserção em recursos alheios, como nas páginas de marcas jornalísticas instaladas em redes sociais - e neste último caso a gestão dos fluxos depende de sua hierarquização interna prévia, ou seja, da emergência de gigantes online. Os veículos de mídia reconstroem suas operações, cujo resultado não precisa ser completo para ser satisfatório, ou seja, o fluxo externo manterá certa autonomia e imprevisibilidade, sem impedir uma boa eficácia da gestão interna de fluxos por parte de empresas produtoras de notícias. Estas articulações de grande porte fatalmente convivem com o desgarro recorrente dos fluxos online. $O$ gigantismo das redes sociais e a inserção nelas de veículos comerciais consagrados não elimina o potencial agregador do trânsito online individualizado. Uma vez que as redes sociais oligopolizadas dependem do chamado usuário gerador de conteúdos, fica mantido um grau de fluidez irredutível nos pilares da hierarquia. 
Dito isso, podemos voltar àquela oscilação na percepção dos editores sobre a relação entre produção de notícias e fluxos de informação. Agora fica nítido que a perplexidade e autoconfiança exprimem um espectro de recorrências bem definidas. Uma instrumentalização progressiva é acionada pelo jornal, que exibe a força gravitacional de seu prestígio e sua capacidade produtiva previamente acumulada. Atores estratégicos coordenam fluxos através de veículos consagrados e de novas plataformas conglomeradas, enquanto indivíduos e agrupamentos sem maior poder de decisão criam competências dispersas porém volumosas que incidem nas operações daqueles atores. $\mathrm{O}$ terreno fluido onde aparentemente todos os caminhos hiperlincados são possíveis é invadido por um punhado de gigantes incontornáveis, que dependem dos usuários como seus provedores de conteúdos e vínculos. Assim, a força de atração dos fluxos se torna uma composição conjunta e desigual de empresas centralizadas e usuários dispersos. Uma vez enredados, os usuários podem gozar dos canais de interação com os jornais, que criam procedimentos cotidianos de trânsito em redes. As ocorrências podem assumir inúmeras combinações. $\mathrm{O}$ que importa sublinhar é a emergência de um quadro específico de hierarquia, interdependência e instabilidade.

\section{Três momentos do processo midiático}

Vimos a partir dos depoimentos de editores uma série de percepções, que indicam um conjunto de recursos, posições e relações. Este conjunto foi composto em função de agentes e de suas ações. Veremos agora o mesmo quadro, mas enfatizando as dinâmicas, que são clivadas ou segmentadas a partir de suas diferentes relações com o ponto de observação dos editores, que é a própria empresa jornalística. Extrapolando os fenômenos jornalísticos que lhes servem de 
ponto de apoio, esses segmentos ou clivagens tem alcance maior e podem ser caracterizados como momentos do processo midiático. O termo "momento" não tem conotação cronológica, como uma etapa que seria sucedida por outra. Os momentos são dimensões do processo, simultâneas e articuladas.

O primeiro momento é feito de relações diretas entre o produtor industrial de notícias e os fluxos de informação, muito nítidas na ligação entre o impresso e o seu portal, com sua abertura para comentários e aferição de acessos. Os vínculos midiáticos aqui possuem um grau forte de centralização nos agentes empresariais produtores. É um momento de pregnância, para usar termo de Antonio Fausto Neto.

O segundo momento se compõe de relações contíguas mas não atreladas entre produtores e fluxos, com estes fluxos podendo assumir ritmo próprio a partir da contiguidade. Se o portal lançado a partir do impresso se situa na primeira clivagem, a inserção do jornal em redes sociais já acolhe com maior maleabilidade o desatrelamento dos fluxos, ainda que visando certa incidência. Esse terreno relativamente desgarrado é aquele usado pelo político que anuncia decisão pelas redes, já antecipando a contiguidade que irritará os editores de jornal impresso. O limite dessas iniciativas de grandes agentes - que buscam envolver o fluxo mas não conseguem completamente - expõe o caráter de direcionamento próprio desse vínculo midiático. É um momento de fluxo adiante, nos termos de José Luiz Braga.

$\mathrm{O}$ terceiro momento se faz de trajetos que não dependem diretamente de decisão, provocação, acolhimento ou incidência de grandes veículos midiáticos e jornalísticos. Esta terceira clivagem se compõe de uma torrente de conteúdos que podem permanecer ausentes da programação e ignorados pelos seus gestores. São todas as mensagens de texto, sons e imagens emitidas, compartilhadas e 
recompostas em plataformas digitais. Nos depoimentos citados, este momento aparece pontualmente num caso de viralização ou metaforicamente na imagem de uma corrente líquida - rio ao lado do lago, como disse o editor. Em instantes excepcionais, os grandes produtores são tocados por estes vínculos midiáticos à deriva, expondo para eles sua existência massiva, sinuosa e silenciosa, do ponto de vista da programação.

A sistematização de fenômenos tomados dos depoimentos de editores é um modo de apreender uma dimensão geral e subjacente, aqui chamada de processo midiático, composta de agentes estratégicos e usuários dispersos, e clivada em momentos substanciais. Agora, esses momentos serão desentranhados dos estudos sobre midiatização.

\section{Momento de pregnância}

Em 2007, Fausto Neto retoma a noção de contrato de leitura para indicar as transformações nas quais ela estaria envolvida. $\mathrm{O}$ contrato é definido como prática enunciativa através da qual uma estrutura de produção discursiva estabelece contato com seus consumidores. $\mathrm{O}$ produtor monta um conjunto de regras que "organizam os modos de vinculação entre as ofertas e recepção dos discursos midiáticos, e que se formalizam nas práticas textuais" (Fausto Neto, 2007b, p. 10). As ordenações sedimentadas no contrato visam atingir um "campo de efeitos" e exprimem uma "lógica de calculabilidade" (ibidem, p. 14).A iniciativa dos produtores não pode ser meramente unilateral, pois o contrato só é eficaz se constituir também um campo de interesses, no qual os consumidores percebam o reconhecimento de suas expectativas, sem o que os próprios produtores não poderiam ser reconhecidos. Fica assim estabelecido um reconhecimento recíproco, porém sempre regido pelos postulados 
do âmbito produtivo, de modo que a interação é assimétrica. Os efeitos calculados pelos produtores fatalmente sofrem descompassos, uma vez que o discurso ofertado será recebido por uma "pluralidade dos atores, nas suas diferentes ambiências, identidades biográficas e construções simbólicas" (ibidem, p. 13). O contrato está fadado a apropriações diferenciadas, devido às múltiplas gramáticas com as quais a recepção o maneja, gerando entre a produção e a recepção "uma inevitável 'situação de desajuste" " (idem ibidem). Assim, o vínculo se dá num duplo registro, composto de ordenamentos e defasagens: por um lado, a oferta incorpora interesses dos consumidores, sempre segundo as prioridades de instâncias produtoras, fora do controle dos leitores, cujo acesso é mediado pelas regras do contrato; por outro lado, lógicas diferenciadas de uso e leitura infletem o contrato ofertado (ibidem, pp. 13-14).O impulso ao ordenamento é tão inevitável quanto a inclinação ao desajuste. Implicado nas apropriações realizadas no âmbito do consumo, impõe-se certo grau de autonomia dos leitores, que não é necessariamente deliberada ou crítica e que não anula nem compensa a assimetria da interação.

Em artigo de 2008, Fausto Neto incorpora a ideia de que, efetivamente, operações de "produção de mensagens passam gradativamente para as mãos dos receptores", que também são convidados pelas estruturas de produção para nelas se inserir como colaboradores, numa expansão de expedientes interativos (2008b, p. 100). O que aparece como um "novo regime de cooperação" faz parte de uma "estratégia, que poderia ser chamada de fechamento de circuitos de sentidos", que por sua vez não pode se realizar integralmente, uma vez que se impõem "as incertezas e as indeterminações desta 'realidade de desajuste', cuja dinâmica exige continuamente a criação de novos métodos de os produtores vincularem o público como colaboradores, desde que "assegurando tal relação com a expressão do seu próprio lugar [o do produtor]” (ibidem, pp. 100-103). 
Forma-se assim a imagem do "co-gestor", situado num "suposto regime de simetrias" que visa "dissimular as diferenças" entre produtores e receptores (ibidem, pp. 101-102). A imagem de cooperação e os novos procedimentos que lhe dão lastro não eliminam a relação básica entre ordenamentos e desajustes, ainda que esta relação se estabeleça em novos expedientes, que pedem especificação. A efetiva apropriação de algumas operações de produção por parte dos usuários não neutraliza a incidência preponderante de "postulados que permanecem no âmbito da lógica do sistema produtivo" (ibidem, p. 101), que por sua vez não anulam o novo ritmo de desajustes, necessariamente acompanhado da instalação das "zonas de pregnâncias" (ibidem, p. 103).

No redesenho dos elos entre produção e recepção, colocamse desdobramentos, bifurcações e acoplamentos em "novas zonas de produção de sentido” (2010e, p. 94). As articulações e contatos que ligavam produtores e receptores se tornam acoplamentos e "situações de interface" que ocorrem em "zonas de pregnâncias" (ibidem, p. 93-94). Nestas, receptores perambulam, migram e quebram zonas clássicas de fidelização, no que seria uma ampliação do descompasso: contatos com um meio são desdobrados em vários outros e as pessoas assistem cada vez menos aos mesmos programas (2010a, p. 64). Assim, as "lógicas dos 'contratos' são subsumidas por outras 'lógicas de interfaces' " (idem ibidem).

Trata-se então de uma efetiva mudança nas interações entre produtores e receptores, porém carregando uma pretensão de diluição de fronteiras em sentido horizontal. Sem dúvida que os "receptores [estão] crescentemente instalados no interior do sistema produtivo", porém essa noção de uma nova protagonização do consumidor está situada em "estratégias de inclusão" que operam "supostas diluições de diferenças". Para apreender a transformação efetiva dos protocolos de interação sem aceitar sua imagem 
igualitária, Fausto Neto está buscando termos consistentes, como a 'emergência de 'zonas de pregnâncias' cujo trabalho enunciativo pode apontar para novas 'políticas de sentido'” (2008b, 100-102).

Somos herdeiros de um vínculo enunciativo contratual entre produtores e consumidores midiáticos com regras relativamente bem definidas que constroem um campo de reconhecimentos, cuja assimetria aparece como uma fronteira, ainda que nuançada pelas defasagens lastreadas em dinâmicas culturais diferenciadas envolvendo uma diversidade de espectadores. Na etapa atual do processo midiático, o contrato sofre uma inflexão, que aparece de diversos modos, inclusive no convite à inserção dos receptores no âmbito da produção como colaboradores. Constitui-se uma zona diferenciada de produção de sentido, que pode ser indicada pelo termo "pregnância", designando a premência da interface, que não dilui o contrato, e a emergência da circulação, que não equaliza os polos da produção e da recepção. Trata-se de um espectro específico de ordenamentos e desajustes, envolvendo tanto cálculos visando o fechamento de circuitos quanto discrepâncias envolvendo a pulverização de fontes e a customização de dispositivos móveis. Essas zonas pregnantes de produção de sentido são entendidas aqui como o primeiro momento do processo midiático, que se distingue dos demais pelo elo indissolúvel que prende todos os componentes a produtores cuja força centralizada é incontrastável.

\section{Momento de fluxo adiante}

Em 2012, José Luiz Braga sublinha a ideia de subsunção dos contratos pelas interfaces (que vimos acima, com Fausto Neto) e elabora um passo adicional na intenção de compor o quadro da circulação. Nas relações entre produtor e receptor, "este último faz seguir adiante as reações ao que recebe", num "processo de 
fluxo contínuo, sempre adiante" (2012b, pp. 39-40). O fluxo pode eventualmente retornar aos emissores originais mas o seu traço fundamental é que não prioriza a devolução de respostas a eles, e nem se fixa na situação de recepção ou em relações diretas entre produtor e receptor (idem ibidem). Também é constitutivo deste fluxo a construção de uma espécie de circuito inverso, que Braga chama de "contrafluxo de escuta" (ibidem, p. 48), sem que seja essencial um retorno ou resposta ao emissor. A produção é modificada pelas expectativas atuais acerca da circulação futura, tornando o conjunto da circulação composto por uma sequencia de antecipações ou ajustes prévios. "No contrafluxo, passamos a produzir a partir das respostas que pretendemos, esperamos ou receamos" (2012c, p. 50; traduzido do espanhol), numa retroação que se constitui como "produção com previsão em contrafluxo" (ibidem, p. 53; traduzido do espanhol).

$\mathrm{Na}$ formulação de Braga, os dois aspectos se combinam e são indissociáveis: é um "fluxo contínuo, marcado pela retroação da escuta prevista" (2012b, p. 40). A partir das interfaces estudadas por Fausto Neto, Braga percebe um fluxo distinto, no qual a produção já não é preponderante e que tem lastro na ampliação e capilarização de instrumentos midiáticos entre agentes sociais que não são apenas os grandes produtores. Concretamente, o fluxo pode se manifestar como comentários sobre um filme, que podem: se desdobrar como polêmicas em bares e em redes sociais; levar a reposições do produto em outras plataformas; incitar sistematizações em espaços especializados; gerar outros produtos, e assim por diante, com cada passo interferindo sobre os outros, e atravessando espaços públicos e privados, profissionais e leigos, grupais e solitários, sem ordem predefinida (ibidem, pp. 39-44).

Este fluxo contínuo pode ser entendido como momento contíguo mas não atrelado aos grandes grupos produtores, ainda que 
não fixado neles, sendo esta a distinção deste momento do processo. $\mathrm{O}$ "adiante" de Braga é intermediário entre uma abertura que se encontra à frente e o polo produtor do qual o fluxo parte - são "reações ao que recebe" (ibidem, p. 39; grifo meu). Assim, o fluxo é contíguo ao recebimento, que (aqui neste ângulo de prospecção) se situa no momento de pregnância. Os grandes agentes produtores não predominam, mas são o ponto de partida indispensável, sem prejuízo do trânsito ampliado e de percurso próprio, que diferencia este fluxo em relação à pregnância. Tal fluxo pode ser entendido como o segundo momento do processo midiático, cuja marca está na capacidade de montar um trajeto específico para além da pregnância de sentidos atrelada à força gravitacional dos produtores oligopólicos.

\section{Momento de deriva}

Até aqui temos duas abstrações bem demarcadas: Fausto Neto concebe sentidos pregnantes na relação entre sistema e entorno, compondo zona própria; e Braga elabora fluxos que se projetam adiante. Creio ser necessário considerar um terceiro momento, marcado pelo cruzamento entre conversação cotidiana e tecnologias de informação e comunicação (TIC), a partir do qual circulam imagens, textos e sons. A principal diferença em relação ao segundo momento é a desnecessidade de contato dos usuários com os produtos dos grandes veículos de mídia. Constitui-se um momento composto de incontáveis vínculos e conteúdos midiatizados que não precisam começar nem terminar pelas empresas produtoras midiáticas de maior porte. São criados produtos com escala e critérios específicos, sem termo de comparação direto com a qualidade de produtos profissionalizados. Seus sentidos se dão ao largo do planejamento empresarial dos veículos midiáticos 
consolidados nas etapas anteriores, embora tais sentidos estejam cada vez mais envolvidos pelas estratégias dos novos gigantes que emergem das TIC.

Estes sentidos à deriva não estão isolados. As grandes empresas ora são obrigadas a recorrer pontualmente a conteúdos deste momento (pescar no rio que passa ao lado, como disse o editor), ora incorporam esses produtos à programação, mas a deriva não se mede por essa disposição. Os agentes dos produtos espontâneos e errantes também introjetam parâmetros de sucesso, de humor, de curiosidade etc. que se moldaram em contato com os grandes produtos. Nem por isso são esses parâmetros que vigoram nesta deriva. Ainda que este momento apresente sua particularidade em relação aos dois primeiros, isso não lhe confere atributos de independência ou autonomia - essa carga de deliberação e de contraposição não tem cabimento. A noção de "amadorismo" é frágil pois tenta descrever fluxos e conteúdos em contraste com profissionalismo. $\mathrm{Na}$ presente prospecção, o termo "deriva" convida ao esforço de investigar sua cadência específica.

Este momento de deriva está implícito em estudos sobre midiatização. Miège também indica que "a 'comunicação nova' escapará de uma maneira ou de outra” dos esforços de posicionamento das "médias em uso" (2009a, pp. 122-123; grifo meu). Fausto Neto percebe que "o dispositivo jornalístico avoca para si a realização de operações (interpretativas) que não deixam o sentido ficar à deriva" (Fausto Neto, 2007b, p. 12). Esse cálculo visando o fechamento expõe a existência de um ritmo errante, que pode ser pensado em termos próprios, com predomínio da deriva. Fausto Neto argumenta que a "protagonização do leitor" é tanto método de fechamento de circuito como exigência da nova dinâmica de desajuste. Se ocorre o acolhimento de receptores no âmbito da produção "enquanto co-operadores de enunciação", isso não elimina a 
preocupação contínua de que receptores "possam vagar para 'pontos de fugas', comprometendo o protocolo de sentido e suas metas comerciais e de audiência" (Fausto Neto, 2008b, pp. 100-101). A preocupação com a deriva e com a fuga, que aparece no estudo voltado às pregnâncias, pode ser reenquadrada: o que é "ponto de fuga" para os produtores tem lastro em um momento específico do processo midiático. $\mathrm{O}$ perigo de escape está radicado justamente neste momento de deriva. Aqui a fuga se realiza, mas não nos termos da preocupação de gestores e sim como ação espontânea de quem nem se importa em fugir, uma vez que o deslizamento não quer partir de ou chegar a nenhum ponto equivalente às metas de grandes operadores midiáticos.

Se "cada vez mais, menores contingentes de pessoas ouvem o mesmo programa" (Fausto Neto, 2007b, p. 9), cria-se também um contingente cada vez maior vinculado a uma conversação que se midiatiza nas TIC: conteúdos midiáticos compostos de imagens, textos e sons, todos produzidos ao largo das grandes empresas midiáticas tradicionais. É um novo repertório de conteúdos e vínculos, cujo interesse reside justamente na espontaneidade dos registros e na proximidade dos envios e manejos, qualidades que não se encontram nas superproduções, para as quais aquele contingente é desviante.

\section{A prospecção}

Se o "ângulo de prospecção" (Braga, 2007, p. 157) tem a virtude de incitar questões, nesse caso específico, ele permite reunir fenômenos e elaborações teóricas e de método servindo como um anteparo às polêmicas comumente referidas à internet, que tendem a nos sugar. A avalanche de opiniões, relatórios de institutos de pesquisa, ocorrências aparentemente decisivas, artigos acadêmicos, 
debates disponibilizados online, operações supostamente inéditas, práticas pulverizadas e uma série de potenciais inscritos em cada uma destas - tudo isso funciona como um turbilhão que propicia conclusões retumbantes lastreadas num grande número de elementos que, afinal, são apenas uma fração das dinâmicas que se impõem. Diante dessa torrente de fatores e correntes, a ferramenta prospectiva apresentada neste capítulo procura vincular um corpus metodicamente construído a formulações de pesquisadores que há décadas se debruçam sobre comunicação e mídia, ligando estudos amadurecidos e fenômenos observáveis para montar um quadro de componentes substanciais.

\section{Manaus, AMAZONAS - Editores entrevistados}

\section{Rede Calderaro de Comunicação}

- Aruana Brianezi, diretora de redação do jornal A Crítica, entrevistada em 22.11.2012.

- Diamantino Júnior, editor do jornal Manaus Hoje, entrevistado em 22.11.2012.

- André Alves, gerente do portal acritica.com, entrevistado em 22.11.2012.

\section{Rede Diário de Comunicação}

- Márcio Noronha, diretor de redação dos veículos jornalísticos da Rede Diário de Comunicação, entrevistado em 23.11.2012. 
- Ademar Vieira, editor do jornal Dez Minutos, entrevistado em 23.11.2012.

- Dante Graça, editor do portal D24am, entrevistado em 23.11.2012.

- Cris Braga, coordenadora de mídias sociais na Rede Diário de Comunicação, em 23.11.2012.

- Também entrevistada: Monica Santaella, ex-editora do extinto Correio Amazonense, atual assessora de comunicação da prefeitura de Manaus, em 21.11.2012.

\section{Belém, PARÁ - Editores entrevistados}

\section{Organizações Rômulo Maiorana}

- Lázaro Moraes, editor-chefe do jornal O Liberal, entrevistado em 30.11.2012.

- Elisângela Soares, editora de conteúdo do portal ORM, entrevistada em 27.11.2012.

- Também entrevistado: Michel Psaros, gerente do portal ORM, Belém, em 27.11.2012

\section{Rede Brasil Amazônia}

- Fábio Novoa, editor de cidades do Diário do Pará, entrevistado em 30.11.2012. 
- Cláudio Darwich, editor portal Diário Online - DOL, Belém, entrevistado por telefone em 30.11.2012.

\section{João Pessoa, PARAÍBA - Editores entrevistados}

\section{Sistema Correio}

- Walter Galvão, editor-geral do Sistema Correio, também editor do jornal Correio da Paraíba e do jornal Já, entrevistado em 26.09.2012.

- Hermes de Luna, editor do Portal Correio, João Pessoa, entrevistado em 06.12.2012.

- Também entrevistado: Linaldo Guedes, Coord. Radiojornalismo do Sistema Correio, em 26.09.2012.

\section{Rede Paraíba de Comunicação}

- Angélica Lúcio, editora-geral do Jornal da Paraíba, entrevistada em 26.09.2012.

- Tatiana Ramos, editora de conteúdos de internet da Rede Paraíba de Comunicação (envolve G1PB, GE e JPonline), entrevistada em 05.12.2012.

- Também entrevistados: Ricardo Oliveira, coordenador de mídias digitais da Rede Paraíba de Comunicação, em 05.12.2012; Aline Lins, editora de cidades do Jornal da Paraíba, em 05.12.2012; Gean Gregório, editor de economia do Jornal da Paraíba, em 05.12.2012. 


\title{
Suíte n 7
}

\section{"Jornalismo sob fluxos e ajustes", de Pedro Benevides}

\author{
José Luiz Braga
}

No âmbito habitualmente referido como "notícias jornalísticas", Pedro Benevides faz uma observação de circuitos e dinâmicas viabilizados por aparatos digitais, e que crescentemente geram e fazem circular informações. Editores de jornais mostram uma percepção do campo jornalístico atravessado e eventualmente ameaçado por novas tendências de circulação de informação na sociedade.

A situação evidencia um tensionamento exercido através de novas tecnologias sobre um campo social já midiático. Mas o que vemos aí não é um embate de tecnologias. Trata-se antes de lógicas interacionais diversificadas em que a tecnologia entra como um componente apenas relativamente condicionante, junto com outros "códigos" de diversas naturezas - a linguagem, as práticas profissionais, os padrões da indústria cultural, os objetivos dos participantes.

Os editores entrevistados reafirmam as bases de sua legitimidade operacional - "informação de qualidade"; seleção judiciosa de fontes; "ritos clássicos de intermediação" (sem estes, a informação ocorreria "sem mediação nenhuma"); credibilidade construída por processos hoje canônicos. Os processos de circulação "concorrentes" aparecem como dispersores, não confiáveis, sem competência profissional, sem legitimidade. 
O texto mostra como os jornais, sob esse tensionamento, rapidamente desenvolveram reações adaptativas - trazendo para dentro de seus dispositivos processos interacionais gerados em circuitos externos, e aí os ajustando a seus objetivos, ampliando suas interações de apuração, antes circunscritas às fontes habituais. Os jornais passam a "se aproveitar das dinâmicas externas de produção", desenvolvem "reações metódicas [...] para incorporar fluxos, incidir sobre eles e se alimentar deles". Isso implica "adaptações tateantes a movimentações imprevistas”. Esses processos modificam lógicas do jornalismo de grande mídia e recompõem usos de redes a serviço de ações pretendidas pelo jornal.

Ocorrem assim revisões do sistema interacional interno do dispositivo de ação jornalística; e de suas relações externas, através da reformulação de circuitos em que o trabalho jornalístico se inscreve. O processo implica também uma experimentação de processos para articular essas potencialidades às lógicas do "fazer jornal".

É claro que os jornais o fazem com o objetivo de assegurar sua autonomia institucional longamente constituída. Mas se ajustam - modificando circuitos anteriores e posteriores à construção da notícia - como caminho necessário para manter relações com a sociedade e demais instituições. $O$ resultado implica um redesenho da estrutura, com novas partilhas ainda em curso de elaboração.

$\mathrm{O}$ estudo de Pedro Benevides mostra o atravessamento que as atuais experimentações de interação social exercem nesse campo. Vamos comentar três questões para as quais a parte empírica e a elaboração teórica do capítulo oferecem pistas. São as seguintes:

- a questão dos modos de credibilidade relacionados à circulação da informação;

- a questão das simetrias e assimetrias na relação entre produtores e receptores; 
- a questão da diversidade de ângulos informativos relevantes para a opinião pública.

Um dos entrevistados argumenta com "a credibilidade para falar sobre o que está acontecendo". O dispositivo jornalístico se assegura, profissionalmente, de padrões operacionais que são a base de sua credibilidade: busca de fontes fidedignas; ouvir sistematicamente o outro lado; formulação redacional sem ênfase em opiniões e preferências; continuidade de acompanhamento de processos socialmente relevantes; seleção de fatos e ângulos mais pertinentes; busca de fontes especializadas nas questões envolvidas. $\mathrm{O}$ aparato profissional gera um padrão de produção que - malgrado críticas que se podem fazer a tendências políticas e a um viés seletivo por temas e ângulos que não abrangem a gama dos interesses sociais - viabiliza, para o leitor, o desenvolvimento de competências interpretativas para "ler nas entrelinhas".

Essa argumentação parece estar na base da posição defensiva de editores perante ações informacionais postas em circulação diretamente a partir das ocorrências sociais. A credibilidade da "informação direta" seria comprometida pela posição interessada do participante da ocorrência, que a informa. Não seriam apresentados pontos de vista diferenciados; detalhes relevantes para uma percepção do quadro completo seriam omitidos; e a informação apareceria destacada do conjunto de ocorrências com as quais o fato relatado faria corpo e sentido.

Não se trata de descurar tais limites - mas de observar que o conceito de "credibilidade" acionado pelo editor é o que corresponde às lógicas interacionais do sistema jornalístico assumido como se fosse um conceito universal. Diversamente, cabe 
perguntar: que tipo de credibilidade pode ser avocado pelos que circulam diretamente suas informações? A resposta é simples: corresponde ao fato de o informador ter participado diretamente das ocorrências relatadas - ou seja: dispor de uma visão interna, participante. Trata-se da credibilidade testemunhal - que tem um peso significativo no acolhimento de informações. Perceber esse critério específico de credibilidade não implica esquecer os limites dessa circulação (como a possibilidade de falseamento e manipulação) para os quais se devem buscar salvaguardas. Mas podemos assumir que, em suas reações adaptativas, o que o jornal busca nas redes sociais é uma articulação deste ângulo de credibilidade testemunhal (ou de engajamento) a seus critérios mais habituais de acolhimento pelo público.

No que se refere às assimetrias na circulação das informações, o ponto básico é dado pela referência feita a Fausto Neto - mostrando que os ajustes, operados pela maioria dos jornais para se conectarem aos circuitos informatizados da iniciativa social, não asseguram simetria. Uma hipotética simetria corresponderia a assumir que a diferença de "gramáticas" entre a produção e a recepção, observada por Verón, deixasse de ocorrer. Fausto Neto mostra, porém, que os processos de produção e circulação jornalística permanecem "no âmbito da lógica do sistema produtivo" - nas "zonas de pregnâncias" do jornal.

A rigor, as relações com o receptor propriamente dito (o leitor, espectador, usuário) não se modificam em quase nada. Podemos assumir uma percepção mais aguda de uma parte dos receptores pelo uso, em paralelo, de redes sociais - mas isso apenas vai se compor com uma aprendizagem prática sobre informação que já vem, 
desde sempre, caracterizando o perfil do leitor - que aprende a usar, selecionar, interpretar a circulação de notícias através da própria prática de ler notícias - complementada pelos debates pessoais na zona da oralidade, que se fazem a respeito dos fatos reportados e das maneiras de reportá-los.

Na realidade, a questão de uma almejada simetria parece ser eco de uma crítica tradicional à grande mídia. Esta seria manipuladora ou opressiva em razão da assimetria entre o sistema de produção e as possibilidades de ação interacional do receptor. Entretanto, não é a assimetria interacional que deve ser posta em causa - e sim o forte risco de uso opressivo dessa assimetria. Não se enfrentam os riscos associados à assimetria por uma exigência incondicional de simetria. Essa última pode, aliás, ser indesejável ou impossível, em muitas circunstâncias: o que seria uma simetria entre o médico e o paciente? Entre o professor e o aluno? O enfrentamento dos riscos pede uma interação explícita e igualitária (o que é diferente de "simetria") sobre os riscos especificamente ocorrentes e sobre como evitá-los.

Malgrado não se obter simetria, no processo jornalístico, assinalamos uma modificação significativa nos movimentos de apuração - em que as fontes tradicionais, cultivadas por seleções feitas pelo próprio jornal, são agora ladeadas por iniciativas de participantes da sociedade em geral, em ações que tensionam os jornais para estimular pautas, acrescentar pontos de vista, reclamar omissões. Pelo menos em alguns pontos do processo, tais procedimentos podem superar alguns dos riscos da mantida assimetria.

A terceira questão que perpassa os ângulos abordados por Pedro Benevides é a da diversificação de ângulos informativos relevantes para a opinião pública. Um dos argumentos tradicionais em 
defesa do jornalismo empresarial é justamente o de assegurar, pela pluralidade de veículos, a diversidade de ângulos políticos na seleção de ocorrências e na sua interpretação. Efetivamente, certa gama de variação parece assegurada - mas fica longe de abranger a diversidade de interesses da sociedade civil e dos debates requeridos para que os leitores vejam esclarecidas as questões básicas da cidadania.

Uma potencialidade de circuitos informativos outros, além de alimentar e tensionar o jornalismo estabelecido, é a de ver a iniciativa direta de temas e debates se diversificar na sociedade civil - sem depender das lógicas da grande empresa midiática. Nessa perspectiva da diversificação estão as duas outras dinâmicas referidas por Pedro, ao lado da pregnância do jornalismo estabelecido. As duas características - a deriva e o fluxo adiante (com seu contrafluxo de antecipações) podem ser vistos como processos de enfrentamento ou de indiferença com relação "às metas de grandes operadores midiáticos". Não são tipos de circuito, mas dinâmicas possíveis em toda uma variedade de circuitos.

A sociedade não se mostra como massa indistinta, como já evidenciado por Barbero, ao enfatizar as mediações culturais no recebimento dos produtos midiáticos. Além disso, tais produtos não chegam ao receptor como se esse fosse o ponto final do circuito. Os processos de fluxo continuado mostram que, ainda que os pontos de partida sejam diretivos ${ }^{103}$, as informações são repercutidas adiante, reinterpretadas, rearticuladas com outros acervos e outras informações - são editadas por cada participante ou grupo.

103 Vale assinalar que não o são, necessariamente. A continuidade do fluxo é efetivamente um elemento de resistência e de desvio com relação a processos assimétricos e centralizados, mas o que chamamos de "fluxo contínuo marcado pela retroação da escuta prevista” se manifesta como processo típico da sociedade em geral (midiatizada ou não), e que pode ser iniciado a partir de quaisquer de seus dispositivos interacionais. 
De modo correlato, a proposta de Pedro Benevides, assinalando - com a adequada expressão "deriva" - fluxos que escapam inteiramente a circuitos pré-planejados e a condensações de diretividade, mostra a potencialidade expressiva e interacional resultante de sequer tentarem tensionar o sistema estabelecido. Tensionam por sua presença, mais que por um programa de ação. Como diz Pedro,

aqui a fuga se realiza, mas não nos termos da preocupação de gestores e sim como ação espontânea de quem nem se importa em fugir, uma vez que o deslizamento não quer partir de ou chegar a nenhum ponto equivalente às metas de grandes operadores midiáticos.

Tais processos de deriva - onde quer que tenham a possibilidade de se manifestar - podem ser vistos como viabilizadores de diversidade, de experimentação comunicacional sobre informações, de busca para outras e outras consolidações. Nesse sentido, quando conseguem assegurar diversidade de ângulos informativos relevantes para a opinião pública, contribuem mais para a sociedade do que o faria uma luta pela simetria. 


\section{As manifestações de junho, 2013: espalhamento e recriação midiática}

Eloísa Joseane da Cunha Klein

\section{Introdução}

Os dispositivos são lugares de observação que permitem estudar o "sistema de relações" na comunicação social (Braga, capítulo 1), que variam de acordo com as circunstâncias e as características do processo social. Os dispositivos interacionais auxiliam no estudo de casos variados, possibilitando tecer suas lógicas em comum assim como sua diversidade. Podemos analisar como dispositivos de espalhamento e recriação midiática aqueles relacionados à divulgação de um acontecimento social, com ações variadas, que podem incluir crítica, adição de comentários e experiências pessoais, mistura de conteúdos midiáticos com outros conteúdos (sejam estes imagens, textos, vídeos, produzidos dentro do circuito das mídias produtoras de conteúdo ou fora delas, por indivíduos comuns, não profissionais), bem como a realização de ações convocatórias de participação nos episódios relativos a tal acontecimento - ainda que a partir de sua propagação informativa.

Com foco nessa diversidade, refletimos sobre elementos heterogêneos que caracterizam tais dispositivos, mas que, por questões pragmáticas, "desenvolvem sistemas de relações perceptíveis na conjuntura social” (Braga, in Bruck e Jesus, 2012). As regras deste sistema 
de relações são socialmente pensadas e tentadas em episódios comunicacionais, que podem ser recuperados, com a finalidade de análise. Para fins deste capítulo, recuperamos episódios comunicacionais desenvolvidos no entorno das manifestações de junho de 2013, no tocante aos aspectos da circulação de conteúdos no Facebook. Para tanto, partimos de circuitos difusos, recebidos via córrego, no "Feed de Notícias" e da leitura de postagens das páginas (Fan Pages) do Movimento Passe Livre (MPL), organizador primeiro das manifestações, e do Estadão ${ }^{104}$, jornal que utiliza intensamente mídias de produção colaborativa de conteúdo na internet, como o Facebook. Consideramos, ainda, os comentários relativos a estas postagens.

A partir destes episódios comunicacionais, observamos características dos dispositivos interacionais, socialmente construídos na forma de matrizes, produzindo regularidades sobre o modo como interagimos. Essa angulação mais geral é o que nos permite pensar na presença de dispositivos de espalhamento e de recriação (sendo que as duas lógicas funcionam conjuntamente). Analisamos também singularidades presentes nos casos analisados, uma vez que dispositivos são modificados socialmente, no momento em que uma situação de interação está em desenvolvimento. Estas singularidades nos permitem desenvolver tensionamentos críticos aos aportes teóricos invocados para o estudo destes fenômenos contemporâneos, relativos à produção de conteúdos fora da mídia corporativa e de suas lógicas de compartilhamento (possibilidade garantida por

104 A escolha do Estadão se justifica sob dois ângulos: a capital de São Paulo registrou o evento que resultou na ampliação das mobilizações de rua (a violenta repressão policial, com saldo de feridos incluindo jornalistas, e a comoção social resultante); e o expressivo índice de compartilhamentos de materiais publicados nesta página no Facebook (Silveira; Pimentel, 2013). A análise da página do Movimento Passe Livre é realizada com o objetivo de contemplar a evolução do acontecimento, já que a página fazia confluir assuntos de todo o país e divulgava convocatórias para os protestos. Nas duas páginas, são considerados conteúdos de postagens e comentários. 
ferramentas que permitem o envio de dados de muitos para muitos, em uma rede de contatos ou mídia social). Podemos estudar as táticas de espalhamento observando os modos como os conteúdos se dispersam, seja em conexão com ações da mídia corporativa, seja em contraposição a estas.

Constatamos, em estudos anteriores, que há uma aprendizagem social constante na percepção e no acionamento das mídias, que se relaciona com o tipo de público prefigurado pelo jornalismo em sua contínua transformação (Klein, 2012). Nessas matrizes de aprendizagem social e crítica, observamos alguns padrões e regularidades socialmente utilizados e perceptíveis pela análise do telejornalismo e suas reverberações, tais como a projeção da relação do corpo em interações com o jornalismo, a adequação da entrevista, a adoção de características e lugares de fala relativos a entrevistador e entrevistado, a análise crítica do conteúdo jornalístico (compreendendo o espaço das ausências e também da edição de conteúdos), a utilização de padrões estilísticos e de entretenimento relacionados às produções midiáticas.

Tais aprendizagens e tensionamentos midiáticos se ampliam com a possibilidade de produzir e publicar, que é estendida potencialmente a qualquer pessoa com dispositivos digitais e acesso à internet - o que Lemos (2005) chama de "abertura da emissão", ou "emissão generalizada". Esta "abertura" já se apresentava como uma transformação significativa no panorama das comunicações midiáticas, mas o quadro se complexifica com a transformação dos ambientes digitais em redes, "envolvendo o usuário em plena mobilidade" (Lemos, 2005, p. 2). A centralidade da circulação (Braga, 2006) nos processos comunicacionais contemporâneos provoca afetações na mídia e no modo como pensamos os processos de midiatização das atividades sociais. A crítica da mídia é realizada concomitantemente à experiência da mídia; a produção 
de conteúdos informativos e de entretenimento passa ao domínio comum - e a própria dimensão da circulação e da dispersão passa a compor as bases destas produções.

Observamos, como ampliação da crítica da mídia, que a sociedade desenvolve diversificados dispositivos, como os dispositivos de espalhamento sobre um acontecimento socialmente vivido, aqui tratando-se das manifestações de junho de 2013. Observamos, nesse estudo, um circuito crítico amplo, que conta com o acervo das Páginas de Facebook acima mencionadas (analisadas desde o dia do primeiro ato, $1^{\circ}$ de junho, até o dia 20 de junho, dia de grandes mobilizações em todo o país). Considerei, ainda, o registro das atualizações recebidas no meu próprio perfil do Facebook (com o objetivo de observar um possível fluxo de informações e comentários, da maneira como ele se apresenta em um perfil acompanhado em tempo real). Tal registro foi realizado durante a noite do dia 13 de junho, quando houve intensa repressão policial às manifestações em São Paulo, o que mudou o curso do evento; e durante o dia 14 de junho. A este registro pessoal, são agregadas reflexões acadêmicas desenvolvidas no período das manifestações.

Observamos que não ocorre, na situação, uma negação do jornalismo, mas um tensionamento crítico a partir da divulgação de informações de outras fontes, da adição da experiência pessoal e da ativação de conteúdos variados. Algumas destas características são amplamente evidenciadas em outros estudos sobre midiatização, como a observação de que o jornalismo disputa o testemunho, a organização discursiva e a atualização do acontecimento com outros atores e instituições (Fausto Neto, 2008b). Parece-nos relevante observar que a pressão imediata por comentários, textos, conteúdos humorísticos e divulgação de imagens, relatos e vídeos constrói, concomitantemente ao jornalismo, o próprio acontecimento e sua abordagem jornalística. Este aspecto evidencia a centralidade da 
circulação nos processos comunicacionais da sociedade em mediatização (Braga, 2007).

A condensação teórica do termo "espalhamento" aparece no livro "Spreadable Media" (Jenkins; Ford; Green, 2013) e se refere à mudança no ambiente midiático, tendo em conta que o modo como a mídia circula perde o centro de referência nas ações de distribuição das empresas e passa a depender de ações de pessoas que vão alimentar circuitos informativos a partir de várias formas de conteúdo. Este movimento é caracterizado por uma dispersão muito rápida de conteúdos via redes formais e informais, conectadas pela internet, na maioria das vezes em ações não coordenadas e até não autorizadas por alguns dos detentores dos direitos de autoria.

A capacidade de disseminar-se rapidamente via redes digitais (que são tecnológicas e sociais) é tomada como "espalhamento" - o que vai se tornar um elemento central almejado pelos negócios de mídia, que passam a tratar do termo "engajamento" para caracterizar o momento em que pessoas selecionam a opção "gostar" de um conteúdo, comentam ou passam adiante, entre seus contatos. Todas estas ações são valorizadas pelo sistema de ranking de informações do Facebook, com o que a possibilidade de um conteúdo midiático ser visto se torna muito maior. Ao propor o conceito, os autores pretendem possibilitar uma ferramenta da análise das formas de engajamento, participação, criação de valores, fluxos que atravessam o fenômeno (Jenkins; Ford; Green, 2013).

Cabe notar que neste texto, trazemos o conceito de espalhamento enriquecido pela discussão conceitual da centralidade da circulação nos processos de mediatização (Braga, 2006; 2011b; $2012 b)$, quando consideramos que a própria lógica da circulação modifica aspectos dos dispositivos interacionais (idem) e passa a reconfigurar o tipo de conteúdo que faz parte da construção de circuitos informacionais (Klein, 2013). 
A crítica midiática faz parte da própria organização do acontecimento e atua na definição dos rumos seguidos pelo jornalismo em uma cobertura dinâmica, que se altera todos os dias. Observamos que as lógicas de espalhamento e recriação presentes nas abordagens coletivas sobre as manifestações também fazem parte de um movimento de contestação da cobertura midiática: contra a cobertura limitada em tempo e tipo de enquadramento, a dissipação de assuntos relacionados às manifestações rapidamente se coloca como uma contrainformação e ação convocatória da participação nos movimentos.

\section{Tessituras das manifestações de junho no jornalismo e fluxos informativos em rede}

Os reajustes das tarifas do transporte público são anuais e, em São Paulo, são previstos para o início do mês de junho de cada ano. Embora sempre tal reajuste ocasione reclamações e alguns protestos organizados, em 2013, certos elementos contribuíram para que essa tensão transbordasse para a organização de vultosas manifestações sociais. Com organização em várias partes do Brasil, o Movimento Passe Livre marcou um ato público para o dia $1^{\circ}$ de junho de 2013, em São Paulo, data em que as passagens de ônibus passaram de $\mathrm{R} \$ 3,00$ para $\mathrm{R} \$ 3,20$. O MPL contou com a adesão e auxílio de outros movimentos e partidos de esquerda, além da organização de atividades em escolas, junto ao Movimento Estudantil. No segundo protesto, em 7 de junho, as ruas do centro de São Paulo já eram tomadas por cinco mil pessoas, segundo a Polícia Militar. Em 11 de junho, no terceiro protesto, eram 10 mil pessoas, que tomavam as ruas com faixas, cartazes e longas marchas.

Com a ampliação dos participantes, os protestos se tornavam a principal pauta das postagens das páginas de empresas jornalísticas, 
no Facebook, e das manchetes de capa dos jornais impressos e telejornais. Em sua página no Facebook, o Estadão publica a foto de capa da edição impressa, com manchete que analisa os problemas causados pelos protestos: "protesto fecha a Marginal e lentidão chega a 226 km”. Até a terceira mobilização, os textos jornalísticos privilegiam as informações sobre as ruas trancadas e consideram a ação da polícia como resposta às manifestações, sendo o clima de tensão acentuado. "Protesto contra aumento da tarifa de ônibus e metrô interdita completamente Marginal do Pinheiros no sentido Castelo Branco. Tropa de Choque foi acionada e joga bombas de efeito moral para conter manifestação" (Estadão, 7 de junho de 2013, Facebook). As fotos da matéria mostram jovens com instrumentos de percussão e bocas abertas, com cartazes e câmeras na mão.

O tom é bastante diferente na página do Movimento Passe Livre São Paulo ${ }^{105}$. A principal utilização da página neste período é para ação convocatória de mobilizações. Estas postagens associam o chamamento à participação nos atos com informações sobre atividades acontecidas anteriormente em outras cidades, como Natal (RN) e Porto Alegre (RS), onde, depois de meses de mobilizações, as tarifas baixaram. São disseminadas informações sobre os custos do transporte na cidade de São Paulo e algumas notícias de empresas jornalísticas são compartilhadas. Há fotos de atividades realizadas, como caminhadas em bairros, queima de catracas, entrada em esta-

105 Apesar de o movimento afirmar que não tinha representantes, entrevistados fornecem informações relativas à uma organização de longa data e repetem aspectos políticos de forma orquestrada, como a definir um tom deliberativo precedente às declarações dos indivíduos que concedem entrevistas. Em entrevista à TV Estadão, membro do MPL enfatiza organização permanente do grupo, desde 2005, confirma aproximação com outros movimentos sociais e partidos de esquerda, declara que a redução da tarifa é a "demanda clara, única, específica”, repetindo texto contido no Facebook. 
ções de trens, ações em frente às escolas, interrupção temporária de vias com queima de objetos. Todas estas atividades são caracterizadas pela página como "a luta contra o aumento". Através das postagens, podemos ter acesso a outros circuitos de divulgação do convite às manifestações (chamadas pelo MPL como "grandes atos"), como cartazes em paredes e muros, faixas em pontes e passarelas, fotos de mobilizações anteriores, nas quais podem ser lidas faixas dizendo: "R $\$ 3,20$ é roubo" e convidando para o ato principal. $\mathrm{O}$ número de curtidas nas postagens aumenta em junho, quando também são adicionadas fotos dos protestos já realizados, mantendo-se o teor convocatório.

As pautas estimuladas pela comunicação do MPL são progressivamente desenvolvidas pelo jornalismo - o que também tem relação com a complexificação temática e abertura do eixo em grandes coberturas. A pauta sugerida pelo nome do movimento, "Passe Livre", passava a ser desenvolvida em entrevistas, pesquisas e referências a outros lugares em que o objetivo havia sido conquistado. Em outra postagem do Estadão, um trecho de fala do prefeito de São Paulo, Fernando Haddad, trazia o índice de que "zerar a tarifa exigiria R $\$ 6$ bilhões” (Estadão, 8 de junho de 2013). O jornalismo, em ação de mediação, coloca textualmente atores sociais em contato, com repercussão das falas do movimento e do prefeito, e com publicação de respostas e ponderações.

Na página do Estadão, no Facebook, embora as postagens sejam sobre o congestionamento causado pelos protestos, os comentários mais curtidos são favoráveis ao movimento: "Se o protesto tem fundamento ou não, eu não sei. Mas eu sei que essa forma de protesto é a única que funciona”. Alguns comentários fazem referência à ocupação das vias e ações de destruição de patrimônio: "Deveriam protestar na porta da prefeitura e não atrapalhar o descanso de quem trabalhou a semana toda". Alguns 
comentários expressam o olhar do participante, em crítica à violência policial: "violência contra as pessoas como se fossem bandidos fazendo arrastão, impedindo a manifestação até então pacífica, isso é AUTORITARISMO, sr. prefeito!”. Em outros casos, o lugar de participante é ressaltado: "não adianta botar a polícia para bater, não vamos parar!”.

Assim como a pauta do MPL tensiona o jornalismo, o movimento circula as informações jornalísticas que convergem com suas análises e ações. Em 12 de junho, o MPL publicou no Facebook a notícia do portal UOL com a manchete: "Aumento de $\mathrm{R} \$ 0,20$ na passagem obriga paulistanos de baixa renda a pular refeições". Adesões ao movimento, em diferentes locais do mundo, são reproduzidas na página do movimento.

Na página do MPL no Facebook, com as mobilizações em curso, comentários críticos da cobertura midiática começam a ser postados. As falas de autoridades políticas também passam a ser criticadas: "O sr. Governador mandou um recado pra gente direto de Paris: interrupções no trânsito serão tratadas como 'casos de polícia'(...). E o que a gente diz pra ele? HOJE SERÁ MAIOR! Vem pra rua". Antes de virar meme na internet, a chamada "vem para a rua" (slogan comercial da Fiat no ano de 2013, em alusão à Copa do Mundo de 2014) já aparecia nas chamadas do MPL.

No dia do terceiro ato convocado pelo MPL, 11 de junho, o site do Estadão foi usado para a cobertura instantânea da ocupação das vias, com chamadas no Facebook. É possível acompanhar os passos da marcha sendo realizada. Postagens de poucas linhas, na lógica da cobertura minuto a minuto, atualizam o número de participantes do protesto, prisões, vias ocupadas, ações de depredação executadas por participantes da manifestação (e tentativa de controle por outras pessoas), uso de gás lacrimogêneo e balas de 
borracha pela polícia e dispersão da marcha. Fotos, vídeos e mapas são usados para compor a linguagem do texto.

Na página do MPL, no Facebook, conta-se a história de uma marcha que seguia por uma via, foi recebida com repressão pela polícia, se reagrupou e seguiu por outra via, até a Avenida Paulista. "Ao invés de garantir para a manifestação um final pacífico, no vão do MASP, a polícia arrancou brutalmente os manifestantes, obrigando-os a se dispersar. Mas não sairemos das ruas enquanto a tarifa não baixar!”. No Estadão, falas de representantes do MPL ou de pessoas identificadas com as mobilizações assinalam que as ações de violência ocorreram após a repressão policial. Membros do MPL passam a ser chamados para entrevistas e, dentro da generalidade do movimento, aparecem rostos. Ocorre a divulgação da data dos protestos, em São Paulo, e o Estadão noticia cidades em que o Passe Livre começa a ser implementado.

Conforme dados de dano ao patrimônio se tornam de domínio comum e são divulgados com fotos da manifestação de 11 de junho, nos comentários das postagens mais pessoas se manifestam a favor e poucas pessoas opinam de forma contrária aos protestos. A crítica da mídia aparece como oposição à seleção de fatos e começam a ser postados links chamando para matérias alternativas. $\mathrm{O}$ texto jornalístico abriga viés contrário ao dos comentários, a partir da fala de representantes políticos da Câmara de Vereadores da cidade.

SP: Manifestantes 'são marginais, delinquentes. Só tinha baderneiros, quase assassinos', diz vereador Andrea Matarazzo (PSDB). Parlamentares transformaram sessão desta quarta-feira em ato de repúdio a protestos. Entre 55, só um defendeu (Estadão, 13 de junho, Facebook).

O Movimento Passe Livre é tratado como instituição organizada, pela mídia e pelos governos. É o que faz com que haja medidas para cobrar a responsabilização do MPL pelas consequências das 
atividades de rua (Estadão, 8 de junho de 2013). Nos protestos envolvendo milhares de pessoas, com ocupação de vias e atos públicos, algumas ações saíram de controle, com atos violentos contra carros, lojas e bancos.

Tomando o exemplo dos atos de violência, os editoriais dos dois maiores jornais de São Paulo exigiram repressão policial mais dura, em 12 de junho de 2013. O Estadão intitulou o editorial como "A hora do Basta: Ou as autoridades determinam que a polícia aja com maior rigor do que vem fazendo ou a capital paulista ficará entregue à desordem”. O teor é similar ao editorial da Folha de S. Paulo, escrito em tom de deboche: "Pior que isso, só o declarado objetivo central do grupelho: transporte público de graça. $\mathrm{O}$ irrealismo da bandeira já traz a intenção oculta de vandalizar. (...) É hora de pôr um ponto final nisso". O Jornal da Globo acompanha o discurso, assinalado particularmente pela coluna de Arnaldo Jabor ${ }^{106}$.

Mas afinal, o que provoca um ódio tão violento contra a cidade? Só vimos isso quando a organização criminosa de São Paulo queimou dezenas de ônibus! Não pode ser por causa de $\mathrm{R} \$ 0,20$ centavos. A grande maioria dos manifestantes são filhos de classe media, isso é visível! Ali não havia pobres que precisassem daqueles vinténs, não. Os mais pobres ali eram os policiais apedrejados, ameaçados com coquetéis molotov. No fundo, tudo é uma imensa ignorância política. É burrice misturada a um rancor sem rumo. Há talvez uma influência da luta na Turquia, justa, contra um islamismo fanático. Mas aqui, se vingam de que? Justamente a causa deve ser a ausência de causas.

106 Os trechos de citação do editorial da Folha de S. Paulo e da coluna de Jabor no Jornal da Globo são buscados em decorrência dos vários compartilhamentos com crítica e recriação destes conteúdos específicos. 
Ninguém sabe mais por que lutar. $\mathrm{O}$ governo diz que vai tudo bem, apesar dos graves perigos no horizonte, como inflação, fuga de capitais, juros e dólar em alta. Por que não lutam contra o Projeto de Emenda Constitucional 37, a PEC 37 , por exemplo? Que será votada no dia 26 , no congresso, para impedir o Ministério Público de investigar. Talvez eles nem saibam o que é a PEC 37. A lei da impunidade eterna. Estes caras vivem num passado de uma ilusão. Eles são a caricatura violenta de um socialismo dos anos 1950, que a velha esquerda ainda defende aqui. Realmente, esses revoltosos de classe media não valem nem $\mathrm{R} \$ 0,20^{107}$.

Tal é a vinculação entre mídias corporativas e mídias de produção colaborativa de conteúdo, que estas publicações editoriais causaram uma repercussão acelerada de informações, opiniões, declarações, relatos de experiência - postas em circulação em fluxos de rede, como resposta aos editoriais midiáticos. $\mathrm{O}$ conteúdo da fala de Arnaldo Jabor é imediatamente disseminado na forma de recortes, comentários, postagens independentes, compartilhamento de vídeo, com críticas, e memes. É o que vemos na síntese que chega por link com a hashtag "Passe Livre":

A verdade é que qualquer pessoa que não concorde, qualquer uma, JAMAIS teve que pegar um trem lotado por anos seguidos às $18 \mathrm{~h}$. (...) $\mathrm{E}$ a verdade é que não se trata mais de 20 centavos. $\mathrm{O}$ aumento podia ser de 5 centavos. De 2, que seja. Não se trata disso, não é por isso que as pessoas estão na rua, e se você não percebe, te falta sensibilidade, falta civilidade, e falta viver em SP de verdade - sair do seu carro e do metrozinho que

107 Transcrição feita a partir da reprodução do vídeo em canal no YouTube. 
você pega na linha verde e ir morar no subúrbio. Ir viver em outra cidade pra que isso te dê perspectiva (Freitas, 2013).

Esta reverberação em mídias sociais sobre o acontecimento midiatizado pelo jornalismo repercute no aumento do número de manifestantes, consequente extensão de vias ocupadas, tipos de afetações à cidade, reforçando a cobertura jornalística e o comentário social - com reconfiguração do acontecimento vivido (Henn, Höer, Berwanger, 2012). A isso se adiciona a greve dos trabalhadores dos transportes em São Paulo, no dia 13 de junho, que deixou milhões de pessoas a pé e com dificuldade de voltar para casa. Neste dia, protestos articulados em poucas horas são realizados em São Paulo, no Rio de Janeiro e em outras capitais. O site da prefeitura de São Paulo foi hackeado, e a imagem do anonymous ${ }^{108}$ apareceu em convocatória para a mobilização. Em decorrência da greve, as matérias principais tratavam da lotação e da espera por ônibus. Em fotos jornalísticas e de indivíduos comuns, máscaras do anonymous apareciam em pessoas, nas ruas, com cartazes. $\mathrm{O}$ informe sobre a hora e o local da manifestação foi repetido pelo Estadão a cada atualização sobre o assunto, no Facebook. Antes das 16h, o site do Estadão postava o trajeto, com mapa, e atualizava dados sobre a chegada dos manifestantes. Se tal tipo de publicação visa angariar a atenção dos fluxos de compartilhamentos em rede, ao mesmo tempo, esta divulgação minuciosa se coloca ela própria como uma contribuição para o chamamento público aos protestos.

108 O jornalismo tende a se referir ao "Anonymous" como uma organização ou "grupo" de hackers anônimos, que atua invadindo e derrubando sites. Halupka (2011), ao estudar o Anonymous em sua tese de doutorado, entende que se trata de uma "comunidade virtual", muito embora não haja site ou local organizador de todos os hackers, há um sentido de pertença e coletividade entre pessoas que se consideram parte do Anonymous. 


\section{Circulação crítica e espalhamento de materiais sobre as manifestações}

As manifestações foram largamente documentadas pelos organizadores, pelo jornalismo e pelos participantes. Ao final do dia 13, conforme se evidenciava a repressão dura da polícia aos manifestantes, espalhavam-se fotos e vídeos de pessoas feridas, incluindo jornalistas, confrontos e repressão policial. Vídeos de participantes da manifestação foram divulgados nas mídias sociais e nas corporativas. $\mathrm{O}$ saldo final falava em 20 mil manifestantes, muitos detidos e feridos. As cenas flagradas pelo jornalismo, com agressão de policiais a jornalistas e pessoas que protestavam, se espalharam rapidamente.

Em sua página no Facebook, o Movimento Passe Livre pede que pessoas divulguem relatos, fotos e vídeos de agressões sofridas. Publica-se uma imagem com fundo negro, em fonte grande, a inscrição "R $\$ 0,20$ ”, com uma mancha de sangue, seguida pela frase: “não é por centavos. É por direitos”. A imagem teve mais de três mil curtidas e quase cinco mil compartilhamentos. Uma diferença grande contra as poucas dezenas de curtidas e compartilhamentos registrados até os dias anteriores.

A repercussão das imagens e vídeos com a agressão de manifestantes por policiais gera uma onda de comoção. Pessoas de todos os lugares do Brasil compartilhavam vídeos, fotos e relatos de quem estava presente nas manifestações: "Uma bomba de efeito moral explodiu perto do meu amigo”. Foram criadas páginas, Tumblrs (um serviço de microblogging), canais do YouTube para divulgar informações, como um Tumblr denominado: "feridos no protesto de São Paulo”. As fotos, vídeos, histórias compartilhadas nestes espaços passaram a ser noticiados pelo jornalismo, como ocorre 
com o vídeo em que um policial bate com um instrumento no vidro do carro, que aparentemente se quebra.

Instituições sociais são chamadas para analisarem as cenas postadas na internet. No Facebook, o acontecimento ganha uma variedade de formas de tratamento. Alguns escrevem pequenos ensaios, procurando as razões que justificam o tipo de ação do movimento e até a violência de alguns atos. "É fato que não dá para protestar sem que os ânimos se alterem, ainda mais quando se está sendo agredido em todos os sentidos". Em comentários, pessoas discutem em torno dos pontos de divergência entre esta cobertura paralela e o tom do discurso jornalístico empresarial, que os comentadores percebem como centrado na afirmação de que a polícia agia para conter as manifestações.

Nas fotos e vídeos produzidos a partir dos protestos de rua, a adesão das pessoas ao movimento fica clara pelo uso do próprio rosto na composição de fotos com cartazes dizendo que não se trata de $\mathrm{R} \$ 0,20$. Se antes o rosto das mobilizações era o rosto dos representantes do MPL, agora há uma diversidade de rostos compondo a defesa da causa da redução da tarifa. Ao tratar das razões além dos $\mathrm{R} \$ 0,20$, uma série de demandas passa a ser projetada nestes mesmos cartazes, majoritariamente em torno da qualidade do transporte, saúde, educação e ações questionadoras dos gastos com eventos esportivos.

A partir da noite de quinta-feira, 13 de junho, quando são divulgadas informações e comentários sobre os protestos, espalham-se materiais conhecidos como memes, que têm uma capacidade de serem copiados de um para outro, mas ao mesmo tempo sofrendo modificação, agregação de conteúdo. $\mathrm{Na}$ internet, estas transformações de conteúdo geralmente são marcadas por humor, contraste de materiais variados, montagem e a ausência de solenidade e de acabamento (Shifman, 2014, p. 2). Durante os protestos, 
observamos o espalhamento de memes com caráter informacional, que comentam um fato de grande impacto, aos quais se associam elementos jocosos, como a frase "enfia os vinte centavos no SUS", em alusão ao dito popular. A experiência de vida também compõe a constituição narrativa de memes: "Vi duas guerras mundiais. E a depressão de 29. Vivi a revolução de 32 . Sobrevivi durante a ditadura. ACREDITEM: não é só por R $\$ 0,20$ ”, diz cartaz segurado por uma senhora, seguido da assinatura: "Nair, 101 anos".

Em outros casos, há uma associação entre elementos factuais e elementos da cultura audiovisual contemporânea, como no acionamento de personagem de séries televisivas americanas. No caso das manifestações de junho, podemos concordar com Felinto (2013) que os memes não parecem estar ligados a algum tipo de capital social dos atores, mas antes provêm de qualquer parte, em geral de anônimos e prevalece a dificuldade em se identificar a origem. A característica viral que o meme assume, entretanto, faz com que ele adquira uma "dimensão política importante" (Felinto, 2013, p. 11).

Participantes das marchas contam suas histórias, divulgam fotos e vídeos. Vídeos publicados no YouTube são compartilhados e comentados no Facebook. Pessoas que tiveram algum contato com as manifestações nas ruas descrevem episódios que singularizam sua participação nestes eventos. Moradores próximos às áreas onde houve repressão policial escrevem sobre seu temor de novos acontecimentos similares. Relatos de situações experimentadas em relação aos protestos são postadas a partir de fotos e de textos escritos, algumas vezes imediatamente após os acontecimentos - ou tão logo haja condições para fazê-lo. Além dos relatos sobre os protestos e repressão policial nas ruas, há um acompanhamento posterior: situação dos detentos, bastidores das delegacias, denúncia de prisão de pessoas que estavam indo ao trabalho ou para casa. Estes relatos, 
fotos e vídeos se disseminam rapidamente, graças ao compartilhamento de muitos para muitos, em lógica de rede.

Membros do Facebook compartilham fotos de seus amigos, do jornalismo, de desconhecidos. Ao compartilhar fotos e postagens jornalísticas e de contatos (ou o que chega através de contatos), as pessoas agregam seus comentários sobre os acontecimentos. Em postagem com compartilhamentos de foto da manifestação no centro de Porto Alegre, uma pessoa de minha rede comenta: "manifestações em prol de um transporte público acessível são muito mais que um apelo por passagens baratas. Trata-se da defesa de um modelo de cidade, onde as pessoas se desloquem juntas".

Fotos (muitas delas, jornalísticas) são compartilhadas durante toda a sexta-feira, inúmeras vezes, e mostram planos gerais, dando a entender a dimensão dos protestos, mostram a ofensiva da polícia, mostram cartazes, expressões e ações dos manifestantes. Relatos sobre a existência de jornalistas entre os feridos ampliam a repercussão do acontecimento sob a lógica de quem estava envolvido com os eventos. Pelo Twitter, no dia 13, uma jornalista da Band relata o que acompanha. No dia seguinte, a fotografia de tela contendo as postagens da jornalista se espalha pelo Facebook.

No dia 14, enquanto os relatos de jornalistas feridos continuam circulando, há críticas sociais ao fato de a cobertura ter sido ampliada por causa dos jornalistas a trabalho que foram feridos. Um dos relatos é de um reporter preso "por porte de vinagre", item que reservava para usar nos olhos para minimizar o efeito do gás pimenta, prevendo o resultado de algum tipo de ação da polícia sobre os manifestantes durante sua atividade de cobertura. $\mathrm{O}$ caso tem elementos cômicos e trágicos tão acentuados que se torna um dos centros de compartilhamento e comentários, e motiva até a organização de páginas no Facebook, incluindo uma chamada a um protesto denominado "V de Vinagre" (em alusão ao filme "V 
de Vingança”). Esta marcha volta a circular como elemento noticioso na mídia. Rapidamente, o relato do jornalista preso por porte de vinagre se transforma em conteúdo tratado com humor, com comentários indignados, e ironia. Este tipo de repercussão criativa adota características midiaticamente desenvolvidas, como o estilo das charges, as referências a acontecimentos circulares, o uso de ilustrações, a associação a personagens conhecidos. Tais características são acionadas desde as lógicas de realização do próprio Facebook, como estilo de frase, organização do meme e potencial de compartilhamentos.

Ao anoitecer do dia 14 de junho, fotos tiradas dos/por participantes dos protestos são espalhadas rapidamente, mostrando jovens que carregam cartazes fazendo a crítica às falas contrárias aos protestos. A replicação intensa das fotos torna praticamente impossível definir o ponto de origem, embaralhando-se fotos dos protestos de 13 de junho (dia da repressão policial), com fotos anteriores e posteriores. Uma destas fotos contém crítica à própria atividade dos usuários no Facebook, é bastante compartilhada e passa a circular outra vez em empresas jornalísticas, realimentando o circuito.

No espalhamento de informações, ocorre o cruzamento de dados. Entre os casos registrados, a história narrada por uma pessoa acaba sendo atestada por vídeo gravado e feito circular por outra. Um homem saía do trabalho quando presenciou uma situação de agressão policial a jovens não envolvidos em atos violentos. Ele relata a cena em sua conta do Facebook. Com milhares de compartilhamentos, o texto chega a outra pessoa, que estava no mesmo local e gravou um vídeo. Esta pessoa deixa um comentário no texto, agregando o link para um vídeo. $\mathrm{O}$ autor do texto responde, agradecendo pelo link, e compartilha o vídeo em sua conta do Facebook, acrescentando, ao relato anterior, a observação: “Taí a prova. Eu estava neste momento lá”. 
Juntamente com estas informações que provêm de quem participava dos protestos, aparecem narrativas pessoais que endossam as críticas levantadas pelo Movimento Passe Livre quando da organização dos protestos contra o aumento da tarifa. Os relatos tratam de situações constrangedoras nas viagens em vagões lotados, do sofrimento de assédio, da ausência de condições que viabilizem a opção de deixar o carro para andar de transporte público. Esta solidariedade com os motivos das manifestações faz com que as pessoas anunciem sua participação nos protestos seguintes, independentemente da cidade em que se encontram. A participação nos protestos é manifestada como desejo de quem posta, como realidade de quem havia anteriormente participado de alguma marcha e estimulada em comentários e compartilhamentos das cidades mobilizadas. Na sexta-feira, 14 de junho, manifestantes em outras cidades se solidarizam com feridos de SP.

Outras pessoas, impossibilitadas de participarem diretamente das manifestações, incorporam os protestos como parte de suas lógicas de participação no Facebook. Pessoas cuja linha de postagem envolve a publicação de episódios cômicos ou inusitados do cotidiano constroem textos reflexivos sobre os protestos, mas ao mesmo tempo mantendo o estilo redacional ligado aos fragmentos de cotidiano: "discuti com as pessoas que mais amo por causa do assunto". Nestas incursões, surgem, em vários comentários, as análises sobre a transformação do acontecimento, em termos de número de participantes e enquadramentos. Em outros casos, há referências ao modo como o acontecimento muda as atividades diárias, a forma como o assunto foi tratado no trabalho, o que o participante viu na televisão, como leu os jornais, como vai usar o assunto em sala de aula.

Como é comum aos usuários do Facebook, a associação com atividades comuns do dia a dia leva em conta algum tipo de fenômeno midiático contemporâneo, que tem a ver com os 
usos da mídia vitalizando as interações e repasse de informações, algumas vezes seguindo a lógica da crítica via recurso irônico. Alguns usuários adotam uma imagem divulgada pelo MPL como símbolo de seu perfil, em lugar da foto pessoal. As reflexões pessoais são, ainda, associadas a outros produtos culturais, trechos do hino nacional, músicas conhecidas, palavras de ordem. Textos midiáticos, literários e humorísticos anteriores aos protestos são relacionados às interpretações sobre o acontecimento, na linha de condenação à repressão e contra a ideia de que se reclamava por centavos.

$\mathrm{Na}$ sexta-feira, 14 de junho, empresas jornalísticas cujos editoriais falavam em ofensiva mais dura da polícia, divulgam notícias enquadrando a repressão policial nos âmbitos institucionais da segurança pública (Página do Estadão, 14 de junho de 2013). Embora algumas matérias jornalísticas sejam compartilhadas, cresce a crítica midiática, que inclui avaliações negativas sobre a pressão pela ação da polícia, que acontece conjuntamente à crítica à instituição policial. Pessoas contestam informações de mídias corporativas usando informações espalhadas por participantes dos protestos. Postagens falam sobre a necessidade de se espalhar informações. Algumas denunciam suspeitas de que seus conteúdos estejam sendo vigiados no Facebook. Entre as atividades de comentários, pessoas analisam, discutem e criticam os textos umas das outras. Análises de atores do campo acadêmico também passam a circular no Facebook. Outras instituições também manifestam-se publicamente acerca dos eventos, como o sindicato dos jornalistas, pedindo garantias para a realização da cobertura.

Estudantes de comunicação e pessoas variadas acionam seu conhecimento de mídia, do modo de interação com empresas corporativas, para alertar sobre a diferença dos fluxos informacionais acompanhados naquele período, em fluxos de redes digitais, e 
outros períodos históricos. Este tipo de análise em geral é feito em comentários de quem não esteve nos protestos, mas teceu considerações a respeito do acontecimento e circulou suas ideias entre seus contatos, que utilizaram as possibilidades de compartilhamento para espalharem tais informações pelas redes digitais.

\section{Pluralidade de falas nas manifestações pós-repressão policial}

Após a intensa circulação de conteúdos em mídias sociais e da multiplicação dos protestos, a Folha de S. Paulo, contrariamente ao edital publicado em 13 de junho, publica um vídeo, em seu canal do YouTube, cujo tom predominante é favorável aos protestos e que expressa, pela voz da jornalista atingida por uma bala de borracha, a discordância com a repressão policial e a confirmação da versão sustentada pelo MPL, de que não havia confusão até a intervenção da polícia. O vídeo, com 12’31" começa com a declaração de um jovem negro, ao lado de outro jovem que tem uma camisa no rosto (o que passa a ser uma marca dos movimentos de junho, como tentativa de proteção contra o gás de pimenta): "me espanta a sociedade ser contra um protesto que é a favor de uma causa pública”. A trilha sonora dá o tom trágico da narrativa, que mescla imagens de ônibus e trens superlotados com imagens e sons de tiros, correria na rua, prisões e confrontos.

Com a repercussão e intensa comoção, o MPL convocou um ato para 17 de junho de 2013 e a quantidade de memes se multiplicou. Simultaneamente às multidões nas ruas, um tom humorado, otimista e encorajador das manifestações acompanha o texto que diz: "não são apenas $\mathrm{R} \$ 0,20$ ". O teor da campanha percorre o mundo e artistas e famosos locais e internacionais abraçam a ideia, incluindo o dono do Facebook, Mark Zuckerberg, que 
aparece sorrindo, segurando cartaz: "it's not 20 cent's. \#changeBrasil!”. Apesar de escrito em inglês, a palavra Brasil adota grafia em português.

Em 17 de junho, as marchas convocadas pelo Movimento Passe Livre são agendadas em todo o país. Em 12 capitais, mais de 300 mil pessoas compareceram ao chamado. Enquanto as marchas aconteciam, em entrevista no programa Roda Viva, dois representantes do Movimento Passe livre respondiam a questões variadas, no dia das grandes mobilizações de rua, 17 de junho de 2013. Os jornalistas requerem postura de entidade do MPL. A seu turno, os representantes insistem no caráter de movimento social, falam de sua participação em conselhos populares e audiências públicas e afirmam que a pauta da redução da tarifa era a pauta das ruas, apesar da multiplicação de demandas possibilitada pelo rápido espalhamento em redes digitais - e consequente aglomeração de públicos dispersos, diferentes daquele originariamente convocado pelo MPL.

As manifestações que reuniram dezenas de milhares de pessoas nas principais capitais do país e muitas outras cidades foram contadas com fotos mostrando a aglomeração urbana, durante o dia, e as ruas cobertas por pessoas iluminadas pelas luzes amarelas das avenidas, durante a noite. Na seção foto do "Amanhecer Estadão", o jornal publicou uma foto de uma leitora, com a imagem da bandeira do Brasil, cercada por pássaros, e tendo atrás de si um imenso céu azul. A manchete de capa dá o tom da mudança de enfoque: "Protesto se espalha pelo País e políticos viram alvo". As fotos em planos médio e conjunto mostram agrupamentos de pessoas com bandeiras do Brasil e faixas tratando de saúde, educação, Copa do Mundo. Nos sites de redes sociais, pessoas postam fotos de sua participação nas marchas.

De 17 a 20 de junho, foram realizadas marchas diárias nas principais capitais do Brasil. No dia 17, primeiro dia de manifestações 
orquestradas nacionalmente, houve transmissão ao vivo pelos principais canais de notícia. No dia 20 , calcula-se que pelo menos 1,4 milhões de pessoas estiveram presentes nas manifestações. Noticiários concentraram suas agendas na cobertura dos protestos. A publicidade foi invadida por um caráter patriótico e convocatório. A Fiat fez circular o vídeo "Vem para a Rua" durante emissões televisivas dos protestos - vídeo originalmente feito em alusão à Copa do Mundo e cujo slogan foi apropriado inicialmente pelo MPL e depois por todos os manifestantes, em postagens no Facebook e em cartazes levados às ruas. Folha de S. Paulo e Estadão falavam em averiguação de abusos policiais. Arnaldo Jabor gravou um vídeo dizendo que havia cometido um erro.

Em análise cartográfica sobre as menções a palavras-chave relacionadas às manifestações, em redes sociais, os autores Arles, Pimentel e Silveira (2013) apontam que os dados indicam "que o ponto de inflexão foi a manifestação do dia 13. A grande repercussão da violência policial aumentou enormemente o sentimento de indignação que foi combustível para a automobilização social e para o disparo de um mecanismo veloz de auto-comunicação de massas".

Essa avaliação, sobre o ponto de transformação, vinha sendo feita por cientistas e ativistas políticos, enquanto os fatos eram vivenciados, como em texto de Venício de Lima, publicado em 20 de junho de 2013: "apesar da proximidade cronológica, parece razoável observar que o estopim para as manifestações populares que estão ocorrendo no país foi o aumento das tarifas do transporte coletivo e a repressão violenta da polícia (vitimando, inclusive, jornalistas no exercício de sua atividade profissional)".

Outra avaliação que ocorre concomitantemente ao desenrolar do acontecimento é de que a massificação da participação das pessoas também resultou num espalhamento do foco de atenção principal. 
Enquanto o Facebook é o grande palco das convocações para as manifestações em todo o País, o Twitter virou o canal onde são postadas as mensagens de incentivo para que os atos continuem. $\mathrm{Na}$ noite dessa segunda-feira (17), após pelo menos dez capitais brasileiras registrarem passeatas, as hashtags mais citadas no microblog foram

\#Verás QueUm FilhoTeuNãoFogeALuta, \#ParabensAoBrasilVamosContinuarComTudo e \#GritaSemTerMedoBrasil. Esses três assuntos figuraram nos Trend Topics durante a maior parte da noite (UOL, 20 de junho de 2013).

Entre os principais compartilhamentos, destacam-se o site do jornal Estadão (SP) e páginas independentes no Facebook, não ligadas a sindicatos, movimentos consolidados, partidos políticos e grupos midiáticos. A participação de pessoas diversas, sem vínculo com estes grupos, também se relaciona ao tipo de expansão de menções ao tema. "Quando comparados o volume de postagens do primeiro e do último dia do período considerado encontramos um aumento de mais 40 vezes ( 8.750 mensagens no primeiro dia, 361.711 resultados de busca no último dia)" (Arles; Silveira; Pimentel, 2013).

“O número de tweets com a palavra 'protesto' no dia 17 superou os 300 mil. No dia 20, foram mais de 50 mil tweets" (Malini, 2013). Malini observa que as palavras gerais "protesto" e a hashtag "vem para a rua" aos poucos dão lugar a outras. "Agora se precisa falar contra a polícia que mata o Amarildo, porque se precisa regionalizar essas lutas, falando de \#protestoBH e \#protestoCE”.

Se num primeiro momento havia consenso com a pauta sobre o transporte coletivo, as análises rapidamente diagnosticaram a abertura para um conjunto de questões que passaram a ser pautadas pelos protestos. A manifestação para haver manifestação aparece 
como grande eixo de crítica ao Estado e ao sistema midiático, com ocorrência de protestos aos partidos políticos e ao trabalho de jornalistas. Sobre a restrição ao trabalho dos jornalistas, o relatório da Abert destaca "agressões e intimidações à população e a jornalistas, além de atos de vandalismo contra veículos de comunicação" (apud Agência Estado, 2013), envolvendo forças policiais e manifestantes.

Venício de Lima (2013) nota um paradoxo entre as ações de negação do jornalismo (mídia) e a demanda, ainda presente, nos manifestantes, de acesso à voz no espaço público, via sistema midiático. Uma ligação entre instituição midiático-jornalística e manifestações é observável na relação entre o comentário político de Arnaldo Jabor minimizando os protestos em decorrência do reajuste da tarifa $(\mathrm{R} \$ 0,20)$ e a eclosão de uma fala pública sobre o assunto: “não são apenas R \$0,20”. Este índice é observável na pesquisa de Silveira e Pimentel. Análises com maior distanciamento temporal (não exploradas neste texto) passam a buscar as vinculações históricas dos protestos de junho de 2013, abarcando as condições de vida na cidade, representação política (Braga, Ruy), ao sistema político, ao direito de se manifestar (Nobre, 2013), à pressão sobre o jornalismo (Silva, 2013).

\section{Considerações finais}

As marchas promovidas pelo Movimento Passe Livre desde sua origem projetavam os elementos de sua própria midiatização. A escolha das frases para os cartazes, a tônica sobre a afirmação da irreversibilidade da demanda, a sincronia do discurso dos membros do movimento (evitam falar de si mesmos, tratam de questões públicas, não privatizam a causa ao movimento, usam dados em todas as entrevistas) e o discurso irônico em comentários, sobre um trânsito já parado, confirmam a capacidade de projeção discursiva: 
"Se a tarifa não baixar, São Paulo vai parar". Há fotos dos cartazes feitos com canetas coloridas, das faixas pintadas em panos pretos com tinta comum, há registros de atividades coletivas remetendo ao bloqueio de ruas. Há uma sincronia e uma redundância sobre a pauta, que qualificam o espalhamento em redes digitais.

Quando temos interações contínuas, espalhadas em diversos pontos sociais, conectados via sistema de compartilhamento de ideias entre indivíduos, nós temos uma transformação nas lógicas da "situação interacional" e nas lógicas da comunicação midiática a ela concernentes. Isto faz com que ocorram transformações nos dispositivos interacionais mais habituais, e na forma como construímos os elementos que embasam nossas relações sociais.

Nos dispositivos de espalhamento e recriação, observamos que se cruzam espalhamento de informações e relatos (incluindo elementos textuais, fotográficos, audiovisuais) de pessoas que se vinculam de algum modo ao acontecimento, comentários de pessoas que participaram ou não diretamente dos acontecimentos, postagens que ressignificam conteúdos a partir de associações com aspectos históricos e de produção midiática anteriores. Um aspecto interessante é notar que este acontecimento é assim vivido pelas pessoas que o comentam, em atividades de vinculação aos contatos pessoais, e a partir da combinação de todas estas ações com coisas sendo feitas no cotidiano de cada um (o tipo de deslocamento ao trabalho, o tipo de vida que se leva, os lugares que se frequenta).

Neste fluxo de postagens, comentários, informações, elaboração de produtos midiáticos fora do campo empresarial da comunicação, nota-se que o campo acadêmico e midiático se diluem, posto que a vivência acontecimental está distribuída em pontos de conexão, sem que haja um nível de distanciamento. $\mathrm{O}$ engajamento com os eventos ocorre na mesma hora em que eles acontecem - e estes eventos são deliberadamente usados/recontados a partir dos 
rastros de informações dos outros, sendo assumidos como parte do que se está fazendo naquele período de tempo. É isto que faz com que se dilua a diferenciação entre recepção e produção. Não porque não há nada sendo produzido ou "consumido", mas porque tudo está em intenso ritmo de circulação - uma característica central dos dispositivos de recriação e tensionamento.

Outra característica tem a ver com as possibilidades tecnológicas e seus usos sociais. Na combinação entre a instantaneidade e o contato permitidos pelos dispositivos móveis e pela internet, há uma extensão das fronteiras deste acontecimento inicial, que se dilui entre várias pessoas, na forma de constituição de uma rede de participação na própria acontecimentalização, fora da mídia e sem tempo e espaço entre quem está diretamente no evento e quem com ele se engajou via redes digitais. A centralidade do acontecimento é a circulação. Assim, formas de "representação" do acontecimento se formam, se espalham e se diluem tão rapidamente a ponto de caracterizar, ao invés de uma posição argumentada sobre $o$ acontecimento, uma partilha de sentimentos imediatos, construídos em contato com outros, pela experiência tecnológica e mediatizada do acontecimento. Sente-se e comenta-se simultaneamente. Neste ponto, os algoritmos passam a ter um papel significativo nas interações, ao medir, qualificar e projetar nossas formas de reação, pela seleção do conteúdo a ser lido e pela oferta de nosso próprio material para outras pessoas.

Estes dois pontos (reação emotiva imediata associada a um comentário, postagem, ou manifestação sobre algo; e qualificação da informação via algoritmo) reconfiguram as características do que chamamos de elementos objetivos que se colocam entre as diferentes subjetividades. Coisas que não imaginávamos tomarem uma dimensão pública e atingir uma variedade de pessoas, como sentimentos passageiros e reações, compõem conjuntamente a 
caracterização de um acontecimento, diluído em redes digitais e midiatizado. E este modo de viver a realidade, transformado, também age profundamente sobre os episódios comunicacionais, tensionando os dispositivos interacionais. Uma questão que se interpõe é o tipo de ação política (tendo em conta ação consciente, organizada e intencional) que estabelecemos, nestas interações comunicacionais. Estes aspectos apontam para o desafio de amadurecer, como sociedade, o debate sobre as consequências desta redução entre o espaço reflexivo e os momentos de discussão pública e ações coletivas.

\section{Sites e blogs citados:}

ESTADAO. Manifestantes fecham todas as faixas da Marginal do Pineiros. Disponível em: http://www.estadao.com.br/noticias/ cidades,manifestantes-fecham-todas-as-faixas-da-marginal-do-pinheiros, $1040021,0 . h t m$

ESTADÃO. São Paulo cobrará prejuízos na Paulista do movimento. Disponível em: http://www.estadao.com.br/noticias/impresso,spcobrara-prejuizos-na-paulista-do-movimento,1040160,0.htm

ESTADÃO. Manifestantes fazem quarto protesto por redução da tarifa de ônibus. Disponível em: http://blogs.estadao.com.br/ estadao-urgente/manifestantes-fazem-quarto-protesto-por-reducao-da-tarifa-de-onibus/

ESTADÃO. Servidores da área da saúde e delegados começam a reunir-se na Paulista para manifestação. http://blogs.estadao.com. $\mathrm{br} /$ estadao-urgente/servidores-da-area-da-saude-e-delegados-comecam-a-se-reunir-na-paulista-para-manifestacao/ 
FOLHA DE S. PAULO. Editorial: retomar a Paulista. Disponível em: http://wwwl.folha.uol.com.br/opiniao/2013/06/1294185-editorial -retomar-a-paulista.shtml

G1. GLOBO. PM apura vídeo que mostra policial danificando vidro de viatura. Disponível em G1.globo.com/saopaulo/PM apura vídeo que mostra policial danificando vidro de viatura. 14/06/2011.

FREITAS, Ana. Não é sobre 20 centavos, estúpido. Blog awesome randomness. Disponível em http://awe-inspiring-randomness.tumblr.com/post/52896959452/nao-e-sobre-20-centavos-estupido

YOUTUBE. Arnaldo Jabor falando sobre as manifestações. Canal Gigante Acordou. Publicado em 16 de jun de 2013. Disponível em https://www.youtube.com/watch?v=RsYB2XpC710. 


\title{
Suíte n ${ }^{0} 8$
}

\section{“As manifestações de junho, 2013", de Eloísa Klein}

\author{
José Luiz Braga
}

A expressão de Jenkins, Ford e Green adotada por Eloísa Klein - espalhamento - metaforiza bem os episódios observados, para caracterizar o sistema de relações nos acontecimentos comunicacionais de junho, 2013. O capítulo faz dois movimentos para dar especificidade ao termo em relação a seu observável. Primeiro, o associa à palavra "recriação", fundamental para a compreensão do dispositivo e dos circuitos que o caso aciona e constitui. Reservando a reflexão sobre "recriação" para a discussão subsequente, relacionada ao processo produtivo dos episódios, vamos observar antes o outro movimento do texto - que é o de mostrar os diversos elementos heterogêneos que participam do espalhamento.

No âmbito mais imediatamente perceptível, é claro, se espalham as falas, em dispersão, através das redes, mas também da grande mídia, até se tornar o assunto mais divulgado no país, mais comentado no momento das ocorrências.

Essa "dispersão" em ações não coordenadas leva à multiplicação dos pontos de emissão. Eloísa cita, de André Lemos, a expressão "emissão generalizada". Não apenas todos repercutem, mas emitem, em relativa sintonia - ou pelo menos em busca de referência a um mesmo eixo de ação. Mas também sem consultação prévia, sem plano ordenado para consistência. Dentre essas emissões, não é possível destacar focos prévios de fala autorizada porque as repercussões - inevitavelmente seletivas - o são não por 
uma centralização programática, mas por igual espalhamento das decisões de selecionar, de dar repercussão a tais e tais falas e não a tais outras.

Um aspecto relevante mostrado no texto é a dos tipos de circuitos que assumem a disseminação dos fatos e das falas - do um lado, esse processo rizomático, entrecruzado, de pontos de emissão e de repercussão; de outro lado, a fala jornalística estabelecida, concentrada em formatações mais habituais de levantamento, seleção, posicionamento editorial e difusão canalizada.

O contraste de processos é elucidativo, pois de sua diferença decorre uma percepção das lógicas de uns e de outros. Ao mesmo tempo - mostra o capítulo - esses dois processos se repercutem mutuamente. Para discordar, mas também para fazer seguir adiante o que foi mostrado no outro lado - seletivamente, segundo as posições preferidas. E ainda para se criticar mutuamente, nas posições e nos processos.

Aqui entra outro tipo de espalhamento - já não só das vozes diretamente participantes e da imprensa. Dada a repercussão dos fatos e das falas, instituições sociais são chamadas a analisar as ocorrências, as posições e as próprias lógicas processuais. Falas acadêmicas acionam um processo que é um pouco de análise, um pouco de participação - como interpretação "a quente". A distinção temporal e substantiva entre ocorrência e análise é um pouco esquecida, e as falas se engajam com suas próprias perspectivas interpretativas.

Outro espalhamento, ainda, aparece na diversidade dos meios de expressão, dos veículos acionados pela interação coletiva. Evidentemente, os meios digitais de rede contemporâneos, disponíveis para a sociedade, são presença marcante. Viabilizam uma comunicação rápida, difusa - mas também de ponto a ponto, e fazendo ponte para veículos com recursos mais sistematizadores. Os 
processos da internet, em geral, participam fortemente da difusão ao vivo, mas também diferida. O lado da imprensa, de sua parte e com suas posições, comparece com a panóplia habitual da grande mídia. Paralelamente, e no miolo das manifestações, os processos intensivos da oralidade, ladeados pelas técnicas mais tradicionais e caseiras, como cartazes de cartolina, escritos a mão.

$O$ fato de que a interação tenha extravasado os meios e se espalhado entre eles, conectando-os em fluxos sempre adiante, é uma boa evidência de que, tão logo os circuitos se diversificam, os processos interacionais não se contêm nas lógicas da mídia, antes respondem a necessidades e desejos para gerar seus próprios processos e lógicas, fazendo a mídia fazer aquilo a que se propõem e direcionando as lógicas e o sistema de relações do episódio. É por isso que os episódios podem ser lidos pela observação do sistema interacional produzido - pelo modelo que aquilo expressa, como dispositivo e como circuito.

Constatamos no caso, aliás, certa dificuldade em distinguir "dispositivo" - enquanto ponto nodal de articulação - e "circuitos" - como concretização de um processo de circulação que se manifesta pela articulação entre diferentes "momentos" de interação, que se conectam. Um dispositivo que se dispersa parece ser, concomitantemente circuito; e circuitos entrecruzados, se mostram como contribuições internas de um dispositivo.

Nessa processualidade complexa de espalhamento, percebe-se a circulação/dispersão como base mesmo do processo produtivo. Mostra-se com clareza a ultrapassagem de uma perspectiva de produto como algo que circula, para vermos a produção como um processo relacionado, desde a origem, à circulação, em forte vinculação com as lógicas desta.

Nos episódios de junho, esses dois aspectos são quase indistinguíveis - a produção decorre da circulação e é uma de suas 
dinâmicas principais. Explicita-se aqui aquele primeiro movimento do capítulo, na compreensão da especificidade do caso: a expressão "recriação" é articulada com o processo de espalhamento.

Como mostra Eloísa Klein, a diferença entre produção e recepção perde sentido. Uma ênfase nas duas processualidades é pertinente apenas para situações diferidas e difusas, como em TV e rádio, em que os dois momentos se destacam. Outros processos correspondem a outras situações - não se ganha em compreensão tomando-os como variante daquela lógica dualizada (como se nessas outras situações, tivéssemos ainda um processo dual agora apenas rejuntado). Seria como entender uma conversa de bar como simples somatória de momentos em que os participantes são ora produtores de fala ora receptores, mudando de perfil a cada momento - modelo que não ajuda a compreender a interação.

Aqui, nos eventos de junho, como claramente mostra o texto que comentamos, o que ocorre é uma imbricação inextricável de ações e falas, de escutas e repercussões. Tanto nos momentos de escuta como nos momentos de expressão, é a ação que os relaciona. Mais que isso: a fala é um componente direto da ação. É nesse ponto, creio, que ocorre um relacionamento estreito entre a participação "ao vivo", na avenida, e a participação por redes informatizadas e outras mídias. Ambas parecem se consolidar como interação entre a ação "física" - ainda que pela simples presença - e a circulação de falas, mensagens, cartazes, notícias, vídeos e fotos. $\mathrm{O}$ cartaz de cartolina é um produto. Esse cartaz, mostrado em um vídeo ou foto, desdobra o produto, que em seguida é replicado, comentado, recriado; e pode estimular, na sequência, outros cartazes em sintonia ou contraposição.

Entre o produto que circula e a circulação que produz, a distinção se assemelha à alternância entre figura e fundo de alguns desenhos. Eloísa mostra uma ocorrência que ilustra bem essa 
circulação-produção: o relato verbal de um incidente, que passa a circular - e mais adiante "encontra" um vídeo do mesmo incidente, produzido por outro participante. $\mathrm{O}$ sentido produzido pelo conjunto é o resultado em produto de características da circulação do acontecimento e ao mesmo tempo faz a circulação avançar.

Nesse ambiente, é interessante observar a geração e constituição de memes - com a "capacidade de serem copiados de um para outro, mas ao mesmo tempo sofrendo modificação, agregação de conteúdo". Uma expressão qualquer, que faz sentido em situação compartilhada, é selecionada como expressiva, repercutida, aplicada a situações próximas (acionando práticas de metáfora ou analogia), até passar a carregar sua própria polissemia. Esse processo comunicacional, modo de composição entre indivíduo e grupos sociais, parece ter sempre existido: nos provérbios, nas frases feitas, nas máximas - que inicialmente foram ditas por alguém, com pertinência pontual para a situação em curso no momento da fala. Torna-se então, pela seleção, pela repercussão e por articulações com outras referências de realidade, fato social e código interacional disponível.

A grande diferença, na contemporaneidade, é que vemos o processo (tradicionalmente de longa ou longuíssima duração) ocorrer quase instantaneamente, diante de nossos olhos e ouvidos - acompanhamos seu percurso, da origem à disponibilidade generalizada. Para a compreensão comunicacional do processo, é preciso cotejar semelhanças e distinções entre os dois momentos, tradicional e atual.

A tentativa que implica a experimentação social das manifestações é claramente de ordem política. Mas é preciso, ainda, compreender o processo político-comunicacional em sua especificidade, evitando considerar apenas as relações de poder, as posições em debate, o sucesso ou insucesso das reivindicações pontuais, o 
grau de viabilidade das expectativas abrangentes que pairavam sobre a disposição das pessoas.

No espaço assumido por esse livro - de perspectiva comunicacional - os aspectos políticos certamente modalizam a questão, como parte relevante do sistema de relações que compõem o dispositivo. Por outro lado, mais que as posições, é relevante refletir sobre a qualidade política impregnada no processo. O sentido político das manifestações parece estar mais no comportamento interacional dos participantes que na substância das reivindicações. Sabemos que grupos partidários, em determinado momento, se distanciaram justamente devido à reduzida diretividade das manifestações e ao acúmulo de expectativas não sistematizadas.

Sem entrar no mérito da eficácia de longo prazo dos procedimentos prevalecentes das manifestações, é preciso reconhecer que estes compõem uma política - e que essa política teve, durante certo tempo, a força de suas lógicas interacionais.

A ausência de uma diretividade forte leva a um espalhamento das reivindicações de toda ordem, com diversidade de temas, de alcance social, de grau de seriedade política e mesmo de posições no espectro em que nos habituamos a ordenar os programas políticos de longo alcance. Essa espontaneidade diversificadora viabilizou uma formidável agregação de motivações, que confluíram para a dinâmica participativa que se evidenciou. Todos os aspectos mostrados no texto de Eloísa - os processos e o material expressivo produzido - caracterizam uma política coletivamente acionada, através dos dispositivos assim gerados. $\mathrm{O}$ processo, articulando indivíduos e ação social, sem exigência de uma política muito concertada em termos prévios, não poderia deixar de ser euforizante.

$\mathrm{O}$ alcance temporal possível de tal encaminhamento é curto. O espontaneísmo interacional não gera prazos longos. Além disso, a agregação da diversidade propicia a participação de não convidados, 
que trazem suas políticas (e ações) eventualmente desagregadoras. A construção de foco em situação de diversidade de ângulos solicitaria debate e negociação, definição de prioridades e busca de dispositivos estáveis.

Mas se essas características interacionais, menos marcadas por códigos rígidos, levam a um fôlego de curto prazo, nem por isso se reduzem a superficialidade, inconsistência ingênua ou inanidade operacional. Há um subproduto diretamente comunicacional que corresponde, justamente, à percepção da possibilidade, ainda que rara, de interações abertas, de sintonias possíveis sem exigência de grandes concertações prévias e sem forçosa hierarquia. No mínimo, há uma aprendizagem de dispositivos e circuitos experimentais, aprendizagem que pode ser acionada - sempre com ajustes - para outras situações que o requeiram, pois esse é o processo mesmo da comunicação. 


\section{Dispositivos "psi" midiatizados: a coluna Vida Íntima}

Monalisa Pontes Xavier

\section{Introdução}

No momento em que o processo de midiatização figura como solo epistemológico das práticas sociais contemporâneas, suas lógicas passam a afetar o funcionamento dessas práticas, bem como as mais variadas experimentações e invenções que se forjam em sua ambiência, incluindo distintos campos de produção de saberes institucionalizados, constituindo uma multiplicidade de dispositivos de interação que se agenciam com a mídia.

Em meio aos diversos campos sociais atravessados por circunstâncias oriundas da midiatização da sociedade, nossa proposição consiste em olhar para o campo das práticas "psi" - Psicologia, Psiquiatria e Psicanálise - por percebermos que tais práticas, imersas no acelerado movimento de midiatização, passam a se agenciar com mídia e, assim, constituem dispositivos interacionais que findam por produzir outros modos de pôr em funcionamento os saberes e fazeres dos peritos da subjetividade. A esses dispositivos, nomeamos dispositivos interacionais "psi" midiatizados.

Tais dispositivos mostram como os saberes "psi" e os sentidos em torno deles produzidos estão se reconfigurando na atualidade, apontando as transformações que os afetam como uma tentativa 
possível de bem funcionar nas interações cotidianas contemporâneas. Essas transformações promovem uma deambulação de importantes referentes canônicos dos campos de saberes "psi”. Com isso, geram tensionamentos e problematizações em torno dos lugares instituídos para gerenciar a subjetividade, na medida em que tal gerenciamento passa a ser realizado em dispositivos que diferem das teorias, técnicas, métodos e espaços criados pela Psicologia, pela Psiquiatria e/ou pela Psicanálise, embora continue nelas se embasando.

Nesse contexto, vamos discutir a produção dos discursos "psi" na sociedade em midiatização por meio do estudo de caso da coluna "Vida Íntima” do Jornal “O Globo", de autoria do psiquiatra e psicanalista Alberto Goldin, a fim de compreender lógicas de interação que esse dispositivo faz circular.

\section{A produção de circuitos e de dispositivos interacionais na coluna "Vida Íntima"}

Não é de hoje a proliferação de práticas de aconselhamento nos meios de comunicação de ampla audiência. Conselhos das mais diversas ordens e prescritos em distintos espaços por consultores dos mais variados lugares de fala e/ou campo de produção de sentidos estão presentes na mídia antes mesmo da própria existência da Psicologia, como é o caso do aconselhamento sentimental, já disponibilizado nos jornais mais antigos, acompanhando o surgimento do jornalismo na Europa, no século XVII, como decorrência de tentativas da sociedade em dar conta de suas questões práticas.

Bem mais recente, o aconselhamento ganha peritos de diferentes áreas de conhecimento. Especialmente a partir de meados de 1990, passamos a assistir, como expressa Castellano (2012), a um impressionante crescimento prescritivo proporcionado pela 
ascendência do chamado campo "psi" e seus discursos expressivamente mobilizados em todos os tipos de mídia.

Tal fato, Bauman (1998) denomina "surto de aconselhamento", quando os especialistas das mais distintas ordens - médicos, psicólogos, psicanalistas, educadores, filósofos, literatos e tantos escritores de autoajuda - começam a povoar os crescentes espaços midiáticos, oferecendo a seus leitores/audiência uma atenção voltada para a construção de modos de ser e estar bem nas esferas social, individual e psíquica. Esse processo descrito por Bauman coincide com o grande avanço tecnológico que possibilitou a circulação de informações de maneira muito mais rápida, bem como $o$ advento de formas de interação por essas tecnologias mediadas. Proporcionou ainda que discussões ocorridas nos espaços de convívio social e de produção de saber adentrassem o espaço da mídia.

Com isso, importantes transformações se processaram, desde um período em que a mídia se constituiu basicamente como deslocamento de lugar do aconselhamento das instâncias presenciais de interação tête-à-tête para os novos espaços que os avanços sócio-técnicos possibilitaram, até o momento em que essa instância se torna elemento constituinte da própria prática de aconselhar, produzindo com ela complexos sentidos emergentes.

No cenário da midiatização em processo, as instâncias de mídia, as práticas sociais dos peritos da subjetividade e as dinâmicas sócio-culturais figuram tão imbricadas na produção de interações que se torna impossível separá-las sem descaracterizar os processos. É assim que surgem os agenciamentos constituintes dos dispositivos interacionais midiatizados, no seio dos quais os "peritos da subjetividade" constituem outras experiências sociais de produção de modos de subjetivação.

Exemplo disso é o que desenvolve Alberto Goldin em sua coluna no jornal. O psicanalista recebe cartas de leitores e responde 
aos conflitos que lhe chegam. Nas respostas, oferta uma espécie de crônica-consulta pautada em significativos referentes do fazer psicanalítico, com acionamentos teóricos e técnicos que paradoxalmente o distanciam e o aproximam de regularidades canônicas que garantem a marca do psicanalista na coluna. A crônica elaborada, nas palavras de Goldin, marca a originalidade de seu enfoque, como caracteriza o colunista seu fazer no espaço em questão:

A originalidade do meu enfoque reside em criar situações imaginárias ou metafóricas que deem ao leitor um espaço de reflexão sobre os problemas, evitando respostas diretas, tipo separe ou não separe. A relativa neutralidade dos textos é muito valorizada porque, mais que soluções, promovem reflexões. Todas as minhas colunas transcorrem dentro do cenário imaginário que guarda a relação com o problema apresentado. É um recurso original que até hoje deu muito certo. (Goldin, 2013, entrevista à autora).

Assim, o profissional faz da coluna "Vida Íntima" um espaço de experimentações em torno das práticas "psi”. Como dispositivo interacional midiatizado, a coluna põe em movimento as regularidades próprias ao campo social em questão e produz interações de outras ordens. Com isso, impõe desafios, traz riscos, produz tensionamentos para com as realidades e os contextos já estabelecidos como consulta "psi". Do seguinte modo a coluna é construída:

"TENHO 25 ANOS. HÁ DOIS ANOS CONHECI Luis, de 30 anos, na faculdade e resolvemos começar um relacionamento sem compromisso. No início nossos encontros eram esporádicos e, no ambiente da faculdade, somos apenas colegas, embora todas as pessoas pensem que somos namorados. Com o tempo passei a freqüentar a casa dele e ele, a minha. Quando conversamos, ele sempre diz que não namoraria 
comigo, mas gostaria de se casar comigo e ter filhos, só que agora não é o momento. Temos um bom relacionamento sexual, sem cobranças. O problema é que minha familia não vê esse relacionamento com bons olhos, diz que eu estou perdendo oportunidades de conhecer uma pessoa que queira de fato um compromisso e que sou muito disponível. Que Luís é egoísta e que preza muito sua liberdade. Nosso relacionamento ébaseado em confiança e respeito, existem muitas afinidades, temos a sensação de que nos conhecemos há muito tempo. Tenho medo de estar me iludindo e perdendo o meu tempo, mas também tenho medo de ele ser realmente o homem ideal para mim e eu desistir por não ter paciência para esperar. Qual sua opinião sobre o assunto? Natália, Rio de Janeiro"

O ÚNICO INCONVENIENTE DO ALBERGUE DE estudantes era proibir a permanência de cachorros. Um dia, um aluno de filosofia acolheu Boby, um vira-lata que se transformou no animal de estimação do grupo. Depois de um amplo debate e reflexão os jovens legalizaram sua presença na República. $\mathrm{O}$ recurso foi pendurar no pescoço dele um pequeno cartaz: "Apesar da sua aparência, Boby NÃO é um cachorro". Esta história circulou no campus e os encarregados acabaram aceitando a duvidosa condição de Boby, que ignorou o impasse. Luís e Natália se amam. O sexo é excelente, sentem simpatia, amizade, enfim, configuram o que as pessoas comuns descrevem como namoro. Notável é que Luís não admite esse rótulo e se apressa em explicar, a quem interessar possa, que são outra coisa: amizade colorida, "ficantes". Luís não teme o amor, sente medo do compromisso e é por isso que, à semelhança dos universitários, encontrou uma solução lingüística para o problema. [...]. (Goldin, 2010). 
O colunista propõe aos leitores um "esclarecimento relativamente superficial e, às vezes, mais profundo, dos sintomas. Procurando que as respostas sejam interessantes não só para o autor da carta, mas para todos que atravessam problemas similares" (Goldin, 2013, entrevista à autora). Além do aconselhamento que trespassa o conteúdo em circulação, temos presente elementos de consulta, o que caracteriza o colunista também como consultor, embora seguindo um modelo de interação canhestra com a Psicanálise em seu agenciamento com a mídia. Esse modo de circular ilustra um fazer que traz em si a lógica de midiatização da prática "psi", pois desenvolve como proposta uma "fala perita" (Giddens, 1991) que, em suas múltiplas facetas, desempenha uma espécie de escuta profissional na ambiência midiática, caracterizando uma reconfiguração do espaço da clínica, que abdica de alguns aspectos característicos em prol da imersão em espaços de mídia.

Nos escritos de Goldin, percebemos que a partilha midiatizada das demandas subjetivas se dá por distintos fatores. Alguns escreventes afirmam não ter condição financeira de pagar pela terapia, outros pagam e não conseguem dirigir sua demanda no têteà-tête ou ainda julgam a terapia improdutiva com relação a alguns aspectos e buscam no dispositivo interacional midiatizado uma complementaridade de lugar para trabalhar o psiquismo. Assim, práticas emergentes como a proposta por Goldin não são substitutivas da tradicional configuração clínica, aparecem antes como uma alternativa disponível que se estabelece na sociedade em vias de midiatização.

Além da clínica psicológica, psiquiátrica e/ou psicanalítica, outros espaços também são buscados paralelamente ao dispositivo, como mostra a carta de Sônia, escrevente que, por não saber lidar com o mal-estar subjetivo que lhe acomete, compra livros, faz 
terapia, vai à igreja, além de escrever a Goldin em busca de algo que lhe proporcione saber sobre o que lhe acontece:

"TENHO OBSERVADO EM MIM UMA CONSTANTE insatisfação com TUDO, no trabalho, nos amigos, no namoro, enfim, com tudo mesmo. No trabalho tenho sempre uma reclamação, querendo sempre um ambiente "ideal". No relacionamento é pior ainda, nunca estou satisfeita, acho sempre que tem que melhorar alguma coisa, da parte dele. É uma insatisfação tão grande, que acho sempre que não sou querida pelas pessoas, por todas elas, fico sempre achando que quando recebo um elogio tem por trás algum outro interesse, já que frequentemente ouço que sou chata e que reclamo de tudo. Acho que as coisas tem que ser muito certas, o que foi dito deve ser cumprido. Na adolescência pensei que deveria ser advogada já que reclamava muito e era persistente. Tenho imensa dificuldade nos relacionamentos, estou no meu $4^{\circ}$ relacionamento longo, tenho 25 anos, $e$ todos eles foram muito conturbados, muitas brigas sempre... Agora estou passando uma fase de altíssima angustia, quando acho que estou sendo enganada, fico tão nervosa que meu corpo inteiro treme e sinto calafrios. Já comprei livros, já fiz terapia, vou à igreja e tento ser mais, mas não sei o que acontece comigo, começo a crer que sou realmente chata, reclamona e uma presença indesejada. Sonia" (Goldin, 2012).

O exemplo apresentado aponta a questão da complementaridade dos dispositivos. Se há procura por mais um espaço de expressão de conteúdo subjetivo, de sofrimentos, de mal-estar, pressupomos que algo escapa ao espaço da clínica, marcando a insuficiência do padrão canônico - e que poderia ser de qualquer outro padrão interacional, pois esse ponto da falta é o que insere o código na lógica dos dispositivos. Quando a clínica - enquanto ordenação de uma práxis 
- por si só não dá conta de circunscrever os dispositivos de interação de ordem psíquica, outros espaços são tentativamente propostos.

Ao modelo de interação canônica, impõem-se pontos de escape, de afetações, de tensionamentos, de desconstruções. Esses pontos são característicos dos espaços compartidos cujos modos de funcionar dissolvem fronteiras e produzem coisas outras. A eles, Fausto Neto (2010e) nomeia como "zonas de pregnância". Essas zonas podem ser compreendidas como os lugares de atravessamentos produtivos dos modos de enunciar e de interagir possibilitados pela midiatização em processo na sociedade. Tais modos, por sua vez, resultam na abertura para outras enunciações constituídas a partir das fraturas enunciativas originárias e as põem em movimento sempre adiante, abrindo espaço para a constituição contínua de outros dispositivos de interação, a exemplo do que aqui abordamos.

As ações concretizadas nas colunas analisadas viabilizam um tipo de interação que reconfigura o setting terapêutico, assim como os lugares de analista e analisando, embora esteja constantemente buscando embasamento nos referentes canônicos da consulta. São esses múltiplos referentes canônicos que garantem a legitimação canhestra do dispositivo goldiniano, como discutiremos. O primeiro exemplo é a postura não-diretiva do colunista e sua recusa em aconselhar, como percebemos: "[...] De nossa parte, continuamos com o hábito de não aconselhar, só alertá-los de que brincar com fogo pode queimar e a única observação válida é que Beto introduziu essa novidade porque não estava satisfeito [...]”. (Goldin, 2012).

Além do referente canônico, outro aspecto pode estar relacionado com a ambição de neutralidade e reflexão em prol de sugestão de solução. Esse aspecto diz respeito a um componente da interação que surge na prática midiatizada, que é o público. Quando há mais alguém além de consultante e consultado, a interação precisa se voltar também ao público. Desse modo, ao primar pela neutralidade e 
pela não-diretividade, além de se aproximar da prescrição psicanalítica, Goldin amplia o alcance da consulta, tornando-a acessível e interessante a vários hipotéticos consulentes que partilham a proximidade de conflitos com o autor da carta respondida no momento.

Tal percepção pode ser certificada em mais um trecho da entrevista com o psicanalista, quando ele assim afirma: "Para outros, o interessante é simplesmente conhecer as angústias e soluções alheias, que às vezes coincidem com as suas próprias. As questões humanas são universais" (Goldin, 2013, entrevista com o autor). Essa afirmação de Goldin mostra uma passagem importante da proximidade com o sofrimento do escrevente para a abrangência como questão coletivamente interessante, que, como acreditamos, não se dá somente em virtude da universalidade das causas humanas.

A referência à universalidade aponta para a produção de um importante traço do dispositivo interacional midiatizado, a saber, as identificações coletivas. As questões do inconsciente não são universais e o analista bem o sabe. Ao assim afirmá-las, Goldin aponta para elementos que escapam a sua resposta e, ao mesmo tempo, retomam a processualidade do dispositivo - que a tentativa de produção de identificações coletivas parece de alguma forma tentar ocultar. Alguns desses elementos dizem respeito à constituição do público, outros são as identificações imaginárias suscitadas nas colunas, muitas vezes através do recurso do descentramento e generalização do problema proposto pelo autor da carta.

O descentramento e a generalização ocorrem por meio da criação de personagens, seja pelo colunista, seja pelo escrevente mesmo, que comumente já se apresenta como personagem e, assim, ao mesmo tempo em que exibe sua questão, se abstém de trabalhá-la em trocas inter-subjetivas, como é característico das terapias e análises. Essa constatação nos remete a Birman (2000, p. 24), quando afirma que, na sociedade contemporânea, "os destinos do 
desejo assumem, pois, uma direção marcadamente exibicionista e auto-centrada, na qual o horizonte intersubjetivo se encontra esvaziado e desinvestido das trocas inter-humanas". O trecho abaixo bem retrata nossa afirmação:

"[...]. Sou bonita, malho, minha vida social é bem agitada, meus amigos me adoram, meus filhos não me dão nenhuma dor de cabeça. Não tenho problemas para "ficar" com algum cara. Esse é o problema: aparecem caras interessantes, mas nunca engrena nada. Dedico-me, sou carinhosa, demonstro, tento ser a mais gostosa... E depois dos 30, penso em sexo 24 horas por dia, às vezes sem me concentrar em algo mais importante. É inadmissível, para mim, ficar mais de uma semana sem sexo. Porém, a ligação do dia seguinte, geralmente não acontece. Sinto-me frustrada e tenho me envolvido fácil por carência de alguém para compartilhar meus finais de semana. Acho que por ser jovem e com dois filhos acabo assustando, estou com a idéia fixa de arranjar um namorado. Daniela". (Goldin, 2011).

Ainda a esse respeito, Sibília (2007, p. 188), ao se referir ao "show da realidade" cotidiana, argumenta que "os sujeitos contemporâneos se autoconstroem como personagens reais, porém ao mesmo tempo ficcionalizados de suas próprias vidas/filmes". Em movimento paradoxal, personagens que exaltam sua perfeição clamam por auxílio urgente, ao tempo em que se resguardam ou se defendem, negando a si mesmos suas demandas, conferindo a responsabilidade de seus problemas a outrem ou até mesmo se desimplicando de suas queixas por meio de elaborações imaginárias.

A criação de personagens aciona ainda outro elemento da tradicional clínica da Psicanálise, que é a fantasia, por meio da qual Goldin aciona o imaginário. A fantasia consiste em importante recurso que faz funcionar uma interação analítica. Ela está na base 
do amor de transferência, que é o que possibilita o estabelecimento da relação terapêutica. Os problemas expressos ao colunista costumam trazer uma visão se não puramente fantasística, certamente bastante pautada em elementos dessa ordem, como vemos no relato a seguir:

"TENHO 32 ANOS, NUNCA NAMOREI, JÁ FIQUEI com vários homens, mas nunca duraram. Sempre tive paixões platônicas, tenho tendência a fantasiar, idealizar... parece que quanto mais impossivel é a situação mais eu me interesso, nesses períodos de paixões, eu fico muito obcecada é como se não existisse outra pessoa no mundo...há um ano conheci um cara, nós tivemos relação sexual, mas ele tem namorada, ficamos um tempo sem nos falar, mas eu não aguentei e depois de 4 meses voltei a falar com ele. Ele perguntou se eu aceitaria sexo sem compromisso e eu disse que sim. Nos encontramos uma vez num Motel, depois disso quis encontrá-lo de novo, mas ele disse que não podia pois a namorada dele estava marcando em cima. Sei que ele não se interessa por mim... A questão é que eu sofro muito com esse modo de funcionamento: querer sempre alguém que não existe de verdade na minha vida, e quanto mais difícil é, mais eu quero e sofro com isso. Gostaria de saber como parar de desejar.

P.S: sou bonita, sei que os homens tem desejo por mim, sou inteligente e culta, sou bancária. Isabel". (Goldin, 2011).

A montagem da resposta do analista também recorre a cenários imaginários que conduzem o leitor a uma cena hipotética que o insere na questão abordada quase como uma personagem, produzindo aproximação e envolvimento, como fazem os contos, as fábulas e as novelas. $\mathrm{O}$ autor da carta é conduzido à cena criada a partir de seu drama, só que agora reconfigurado e menos sofrível 
que sua história. $\mathrm{O}$ fato queixado é transformado em ficção e, com isso, realiza duas ações: distancia o leitor de seu drama, de modo que possa olhar de fora para o mesmo e, em seguida, reaproxima-o da questão, porém essa aproximação se dá como a de um ator que precisa dar vida a uma personagem e, no espaço da encenação, resolver os conflitos vivenciados que não são conflitos seus, mas de sua identidade fictícia. A segunda ação se assemelha a uma ação interacional característica da prática clínica psicanalítica, que diz respeito a vencer as resistências para chegar ao sintoma e, no espaço em que esse foi gestado, a fantasia, resolvê-lo.

Além da fantasia que faz o dispositivo goldiniano funcionar, outro referente da Psicanálise frequentemente acionado é a ideia de inconsciente, repetida em grande número de respostas, nas quais o analista o associa à constituição dos sintomas sobre os quais discorre, tal qual se segue:

[...] A confusão surge quando se trata o inconsciente, que é o berço dos desejos, como se estivesse regido pela consciência, lugar certo para exigir honestidade e correção. Pedro não eliminou (nem jamais eliminará) os indícios imaginários de infidelidade que, como é óbvio, não obedecem a regras e proibições. Ainda mais, é proibindo-os que poderão reaparecer de modo bizarro em outros contextos, como na impossibilidade de expressar a palavra "amor" em voz alta [...]. (Goldin, 2012).

$\mathrm{Na}$ ação comunicacional acima ilustrada, percebemos a tentativa do analista de levar ao público não especialista um pouco de compreensão da sua teoria. Isso afirma sua perícia, confere credibilidade por parte dos leitores aos seus ditos e ainda sustenta o colunista no lugar do que sabe, do "suposto saber". Podemos ver como ele desenvolve explicações sobre a relação entre inconsciente 
e sintoma, com forte acionamento de sua teoria, embora na tentativa de tornar seus conceitos facilmente apreensíveis.

Para tornar amplamente compreensíveis as ideias que maneja, Goldin costuma digestivá-las, fazer uso de metáforas capazes de inserí-las nas cadeias de significados acessíveis ao grande público, que dificilmente entenderá o processo que está mobilizado na crônica como um encaminhamento analítico tentativo, no entanto, muito possivelmente compreenderá as representações discorridas, a exemplo do que ocorre com a metáfora do Superman, no trecho de carta transcrito:

[...] Algumas características femininas, como sensualidade, beleza, desinibição ou outras, operam para a ereção como Kriptonita que, por suas singulares características, oferece uma referência importante para a psicanálise. Kripton é o planeta da infância do Homem de Aço, o lugar onde teve e perdeu suas primeiras experiências e sensações. Por isso dizemos, sem medo de errar, que Kripton é o inconsciente do Super-homem, seu passado infantil esquecido e talvez a beleza ou desenvoltura sexual da Pérola sejam o cristal verde que recupera primitivas sensações do parceiro e promove regressões nas quais o Super-macho se desmancha feito gelatina, ficando reduzido à patética condição de criança indefesa nos braços de uma mulher enorme e poderosa. Quando o Super-homem perde poder, cede o mesmo à sua parceira e o sentimento que lhe resta é de forte e injustificada humilhação, que importa só ao protagonista, nem tanto a mulher que está ao seu lado, habitualmente mais compreensiva e tolerante. Não esgotamos o tema, fomos mais didáticos que científicos, resta acrescentar que a Kriptonita só ataca os Super-homens. Os homens simples e sem super poderes estão a salvo. (Goldin, 2012). 
Embora mantidas importantes referências da codificação canônica necessárias para o profissional gozar da credibilidade perita que seu saber lhe confere, as regularidades são constante e intensamente tensionadas na ambiência do dispositivo ao qual o fazer canônico se agencia. Esse sutil movimento de garantir elementos mínimos de um código partilhado e, concomitantemente, permitir as incidências advindas dos campos sociais como condição para pôr o dispositivo em movimento pode ser frequentemente vislumbrado, seja na apropriação deformada que o colunista faz da ideia de diagnóstico, na postura diretiva característica do conselheiro, em detrimento da proclamada não-diretividade, entre outros aspectos.

\section{Traços comunicacionais do dispositivo "psi" midiatizado}

A fim de compreender a coluna "Vida Íntima" como um dispositivo que gesta modos de interação na sociedade em midiatização, vamos destacar traços comunicacionais do objeto em discussão, de modo a perceber e problematizar suas lógicas de montagem, suas estratégias de circulação e seus modos de funcionamento.

Para bem funcionar, a coluna goldiniana se apresenta como um híbrido que comporta, além dos já mencionados referentes da Psicanálise, traços de outros campos que se atravessam em prol de uma elaboração de outra ordem, que é o dispositivo. Exemplo dos campos mesclados nos escritos são a Literatura, a Psiquiatria, a Educação e o senso-comum. Texto distinto do aconselhamento sentimental e que se aproxima de uma espécie de ensino não-formal sobre questões socialmente partilhadas, questões essas que se organizam como operações de sentido em torno do mal-estar, do sofrimento, da angústia, da solidão, dos relacionamentos interpessoais e de uma variedade de desencaixes subjetivos no contemporâneo. 
Diante de novos modos de subjetivação, o escrevente se percebe sem lugar e demanda de Goldin qualquer diretriz que the permita algum grau de reencaixe. Temos aqui configurados dois problemas: um problema específico de mídia; e outro, geral, de comunicação. A começar pelo problema de mídia, quando essa instância dissemina uma profusão de "eus", eles tensionam diretamente os anteriores referentes identitários disponibilizados aos sujeitos que, por sua vez, se vêm confusos ante a desterritorialização em processo. $\mathrm{Na}$ ambiência midiática se efetiva a desterritorialização e também a busca por respostas às problemáticas daí advindas. Nesse ponto, marcamos o tensionamento que o campo da mídia imprime ao campo psicológico, que se presentifica quando a mídia funciona como lugar de enodamento de novas questões subjetivas, com as quais o campo habitual não está acostumado a lidar. Daí surge a demanda pela gestão de outros espaços, outras práticas e outros dispositivos.

A segunda modalidade de problema apontado diz respeito aos modos de comunicar, que se relacionam com os recursos disponíveis para compor a enunciação. Quando o escrevente demanda uma classificação, um atestado de normalidade ou uma diretriz para seu sintoma, além de tornar dita sua inquietação, anseia por um vocabulário capaz de lhe possibilitar enunciar seus conflitos e a si mesmo. Está expressa aí a necessidade de comunicar o mal-estar, assim como a carência de recursos que possibilitem a comunicação. Observamos que direcionar uma fala a proporcionar tais recursos é uma importante ação comunicacional desenvolvida por Goldin e que garante o funcionamento da coluna "Vida Íntima" como um dispositivo interacional.

A articulação entre a questão de mídia e a questão social geral, de comunicação, compõe os processos de midiatização da sociedade, em que as questões sociais as mais diversas sofrem incidências 
dos processos midiatizados e, por sua vez, os múltiplos campos de ação na sociedade fazem experimentação midiática segundo suas próprias lógicas, agenciando assim outros processos, em busca de outros resultados.

A oferta de vocabulário pelo colunista concede o elemento que faz a interação seguir adiante, ou seja, concede formas de enunciar. Essa afirmação vai ao encontro do que Braga (2006, p. 72) constata sobre os dispositivos, quando assim sintetiza: "A sociedade nos oferece, constantemente, esses dispositivos sociais para 'com eles' expressarmos a singularidade de nossa fala". Essa oferta de vocabulário é um dos elementos significativos do dispositivo goldiniano e insere o leitor na complexa rede que envolve a interação. Mais que isso, introduz um terceiro ator no dispositivo: o público.

Como afirma Braga (2006, p. 80), "todo texto se organiza para destinatários ou constrói destinatários sob medida”. Esse movimento, bem o faz o colunista que, ao construir estratégias de montagem de seu dispositivo, forja seu público. No mosaico de estratégias desenvolvidas, Goldin produz endereçamento, ou seja, inventa o seu leitor a partir do que a ele é ofertado, dos modos como ele é acionado. Esse acionamento, por sua vez, se organiza em torno de elementos como os tipos de consulta disponibilizados, os problemas referidos e o tratamento dos mesmos, as questões abordadas, assim como as táticas redacionais que envolvem a construção de respostas. Percebemos nas táticas de respostas do colunista alguns movimentos comunicacionais, dentre os quais, os modos como aciona seu público, despertando interesses múltiplos, transformando questões de foro íntimo em demandas socialmente partilhadas e oferecendo substância reflexiva à vida prática dos leitores.

Por meio das estratégias de construção do público, o dispositivo goldiniano desenha um modelo de interação que impulsiona $o$ elemento comunicacional sempre adiante: um especialista divulga 
suas elaborações, a ele se dirigem escreventes que solicitam auxílio ao seu saber, a resposta do especialista se volta não mais apenas ao escrevente, mas a todo um público leitor, interferindo no conteúdo dos escritos e, assim, amplificando respostas sociais que darão continuidade ao ciclo de usos e apropriações. Isso caracteriza a funcionamento de um circuito interacional.

Além da construção de público, outras ações permeiam o complexo processo de produção de experimentações condensado no dispositivo. Dentre elas, as operações de escuta desenvolvidas por Goldin. Essas operações se pautam nas demandas recebidas pelo analista, a partir das quais ele desenvolve uma intenção de escuta que, a nosso ver, está prioritariamente voltada a uma escuta pública, em detrimento da escuta individualizada, provavelmente requerida por cada escrevente em particular. Ao catalogar as cartas e selecionar aquelas que despertam maior interesse público, o analista parece ouvir coletivamente o que lhe chega e se ocupar do que de mais representativo da maioria ele possa encontrar entre sua coleção.

Nessa ação se constitui uma espécie de divã coletivo que ilustra um aspecto de deambulação da consulta tensionada por processos que estão sendo tentados. Cada escrevente destina seu sofrer individualmente ao colunista e dele espera uma resposta particular, mesmo em espaço massivo. $\mathrm{O}$ analista, por sua vez, transita entre as várias enunciações de angústia e mal-estar que recebe, cruzando-as entre elas em busca de alguma que fale para o coletivo, pois é ao coletivo que ele busca falar para, assim, fazer funcionar o seu dispositivo.

Mais um elemento de tensionamento da consulta pelos processos tentativos do dispositivo se presentifica na transformação do ator, que deambula por vários espaços e campos sociais e reflete isso nos distintos posicionamentos decorrentes dos múltiplos acionamentos teóricos realizados no interior de uma mesma coluna. 
Como um flâneur, Goldin transita descompromissado pela maior variedade de campos - sociais e de saber - que pode alcançar. $\mathrm{O}$ espaço onde constrói sua prática, a coluna do jornal, lhe permite devanear, se desprender dos códigos estabelecidos, confrontar a instituição dos saberes "psi”, ensaiar um pouco de Filosofia, de Literatura, optar pela Estética, ser jornalista ou retornar para o lugar de analista. Essas deambulações, por sua vez, acontecem juntamente com o deslocamento dos processos interacionais, que se dá de forma rizomática, sem uma origem definida ou um ponto de finalização, mas, diversamente, se configurando nas heterogeneidades que se constituem nos atravessamentos entre as práticas, os campos sociais e os dispositivos interacionais.

A partir das deambulações e estratégias interacionais que forjam o dispositivo em estudo e produzem modos distintos de fazer circular questões "psi", percebemos um tensionamento em torno das modelizações aconselhamento e consulta quando atravessados pela mídia. Constatamos que o fazer de Goldin é substancialmente diferente do aconselhamento na mídia, mas também do padrão canônico de consulta, escapando das modalidades interacionais precedentes e apontando para a produção de modificações tentativas que nos levam a nomear sua oferta como consulta transformada.

Transformada pelas demandas sociais, transformada pelos modos de interagir, pelas expectativas que giram em torno dela, pelo que pode oferecer como resultado e por todo o leque de construções enunciativas que, a partir dela, redefinem a própria prática social, na medida em que ofertam outros elementos de inteligibilidade da vida e de participação nos dispositivos sociais. Desse modo, vai ao encontro dos interesses e artifícios dos sujeitos para bem participarem do dispositivo goldiniano, que, tal como outros 
dispositivos canônicos ou tentativos, são insuficientes e, por isso, em constante processo autopoiético.

\section{Deambulações, ensaios e invenções... a consulta transformada}

Os deslocamentos produzidos no dispositivo "psi" midiatizado que estudamos nos levam a caracterizar os fazeres gestados em seu espaço como uma consulta transformada, a partir de alguns aspectos de deformação resultantes das afetações mútuas que se processam entre os saberes implicados em fazer o dispositivo funcionar.

O primeiro desses aspectos, como já discutimos, é o profissional perito que opera uma escuta nos diferentes lugares nos quais se insere, bem como empreende a gestação de enunciados e práticas em torno dos saberes em foco. Desse modo, produz, através de tentativas distintas sobre os feitos psicológicos, operadores que transparecem a possibilidade de fazer funcionar processos interacionais em torno de questões "psi” em outras ambiências.

Nesse procedimento tentativo, o profissional deambula juntamente com o deslocamento dos processos interacionais. Exemplo disso é Goldin que, no espaço do jornal, além de analista é cronista, literato, consultor, dentre outros papéis desempenhados na coluna "Vida Íntima". Esse trânsito de lugares e de referentes é bem característico da sociedade em midiatização, que imprime uma dissolução de fronteiras estabelecidas entre campos e práticas sociais e desconstrói as segmentações identificatórias preestabelecidas em prol de um delineamento fluido das mesmas nas interações em que elas acontecem, de modo que o ator se define pelo movimento entre suas múltiplas atuações nas práticas mesmas. Isso corrobora a afirmação de Fausto Neto (2010e, p. 88) de que na midiatização: 
Os papéis dos atores (os intelectuais, por exemplo) também se reformulam uma vez que os mesmos passam a jogar o "contrato da performance das novas lógicas midiáticas", situação em que parecem mais "representar para si mesmos", ou para estas novas interações, do que interagir para com a sociedade, nos moldes antigos.

Também os fazeres insurgentes no dispositivo em análise aparecem em constante movimento que se realiza em resposta às demandas das interações das quais participam. Os saberes lançados à midiatização, como ocorre no agenciamento que abordamos, devem abdicar do linguajar acadêmico para se tornar acessíveis; adotar diferentes modos de interagir para viabilizar as trocas com a sociedade em geral; ressignificar os acionamentos teóricos em prol de maior aceitabilidade; prescrever modos de ser e, com isso, adentrar nas questões de foro íntimo; miscigenar elementos de outros campos e muitas outras ações tentativas de melhor se inserir nas práticas cotidianas da contemporaneidade.

Nessas metamorfoses, findam por deslocar os modos de fala, muitas vezes aproximando-os da figura de conselheiros, da linguagem fantasística da literatura muito usada por Goldin, ou ainda das prescrições biopolíticas de normatividade. Esses modos de fala transformados, por sua vez, delineiam o que o dispositivo oferta aos que com ele interagem. Com isso, o dispositivo produz distinta modalidade de interação entre os campos sociais e outros elementos de inteligibilidade da vida e dos processos sociais, que são transformados na interação mesma.

Essa outra modalidade interativa, resultante das insurgentes transformações que acontecem com o funcionamento do dispositivo, reverbera nos processos sociais de muitas maneiras, dentre as quais apontamos as expectativas e as crenças em torno das suas ofertas. Em um circuito que envolve produção, recepção e sistema social 
de resposta, como discute Braga (2006), encontramos uma relação complementar entre ofertas e demandas, no centro das quais se constroem as expectativas acerca do dispositivo ou, mais especificamente, a respeito dos saberes envolvidos na constituição do mesmo.

O que espera um sujeito da Psicologia, da Psiquiatria e da Psicanálise disponível nas páginas de jornal não é uma questão simples - talvez nem passível - de circunscrever, por dois motivos principais: o primeiro deles, pelas singularidades que pautam os modos com que os sujeitos passam a interagir pela mediação dos dispositivos; e em seguida, pelo fato de que não há nessa relação qualquer viés de determinação padronizada, do tipo: o sujeito lê "Vida Íntima" pelo interesse nas diretrizes de conduta apresentadas. Acrescentamos a isso a fluidez constante que atravessa as expectativas. Em determinado momento, a coluna "Vida Íntima" pode interessar como leitura despretensiosa ou entretenimento, o que facilmente pode mudar em momento seguinte para o interesse em prescrições para lidar com o mal-estar; ou adquirir vocabulário para anunciar sua intimidade.

As motivações para a busca pelos dispositivos interacionais "psi" midiatizados envolvem questões multideterminadas que incluem aspectos sociais, individuais e subjetivos. Desse modo, os dispositivos interacionais midiatizados "psi" podem surgir como possibilidade condizente com as demandas socioculturais da contemporaneidade. Enquanto uma análise tem longa duração ${ }^{109}$, suscita grande exercício de elaboração intelectual, os resultados não são imediatos, exige a exposição sistemática ao outro e o investimento financeiro é alto; as colunas de Goldin oferecem

109 Os psicanalistas discutem inclusive sobre a possibilidade de término de uma análise, discussão que se inicia com Freud (1937) e seu texto "Análise terminável e interminável”. 
balizamentos de forma prática e imediata, já estão prontas e em linguagem direta e acessível, as respostas necessárias se encontram nas entrelinhas e a baixo custo.

Nesse sentido, as práticas estabelecidas nas interações midiatizadas bem parecem estar em acordo com as demandas do momento sócio-histórico nas quais são produzidas, fato que nos leva a enxergar uma tessitura bem mais complexa do que as demandas ou expectativas imediatas de sujeitos particulares. Subjetividades forjadas em tempos de midiatização encontram nos dispositivos também midiatizados atrativos modos de destinação de suas causas.

Os dois dispositivos interacionais "psi" - o clássico e o midiatizado - obviamente disponibilizam coisas distintas, mas ambos se propõem a tratar de assuntos referentes a questões psíquicas. Essas distinções, contudo, muitas vezes são desconhecidas do público leigo que, quando anseia pela consulta analítica, vagamente sabe o que dela esperar. Além disso, diante dos sintomas, muitos buscam resultados que são vistos como respostas as mais rápidas e diretivas possíveis, o que está em acordo com os modos de fala dos saberes "psi" quando midiatizados, já que se referem a marcas do próprio processo de midiatização. A nosso ver, esses traços apontados contribuem para tornar tal público disponível para as distintas formas em que a consulta se apresenta, desde as muitas figurações das tradicionais consultas "psi" até os mais variados espaços em que ela aparece midiatizada.

Outro deslocamento percebido na midiatização da consulta é a deambulação dos interlocutores. Na relação midiatizada, o sujeito que inicialmente transita na recepção deixa de ser necessariamente o consulente, em situação de instabilidade psíquica e que busca de algum modo uma cura, seja qual for a representação por ele elaborada acerca da mesma. $\mathrm{O}$ próprio ato de apenas transitar pelo lugar da recepção já desloca o interlocutor, que em alguns momentos 
ocupa o lugar da produção e, na interação com o dispositivo, nem sempre se coloca em busca de consulta. Isso vai ao encontro de uma característica da midiatização que é a de promover a insurgência de multiplicidades nos dispositivos em seu contexto gestados. Consulente, leitor, audiente, escrevente, paciente, interlocutor, aprendente e muitos outros lugares podem ser assumidos por um mesmo sujeito, simultaneamente ou não, quando em interação com os saberes "psi” nos dispositivos midiatizados. O "novo" interlocutor é tão protéico quanto os saberes agenciados na midiatização.

Outro importante aspecto de transformação que atravessa a consulta midiatizada diz respeito à relação estabelecida entre as perspectivas do saber especialista e das construções do senso-comum. Um dos significativos feitos da midiatização em processo é a diluição de fronteiras entre os diversos campos sociais e, consequentemente, a diluição das distinções mais fortemente características de cada um deles, pautadas em suas regularidades canônicas. Pois bem, quando agenciados na ambiência midiática para formar os dispositivos interacionais da midiatização, essas distinções tendem a desaparecer, de modo a continuamente dar lugar a coisas outras que podem se reconstituir em outros agenciamentos, em movimento ininterrupto de insurgentes distinções a todo tempo em gestação. Isso é um traço constituinte dos dispositivos. Como argumenta Deleuze (1990, p. 159), "todo dispositivo se define pelo que detém em novidade e criatividade e que, ao mesmo tempo, marca a sua capacidade de se transformar, de se fender em proveito de um dispositivo futuro".

A coluna "Vida Íntima” cria saberes e fazeres perfeitamente distintos para com o campo psicológico e seus processos, sua ideia de consulta psicanalítica. Essa distinção empreendida é o que permite ao campo falar com êxito para fora dele. Tal produção de fala para interlocutores extra-campo, contudo, não é especificidade dos dispositivos da midiatização. Na clássica modelização de relação 
terapêutica ou analítica, o cliente ou analisado é, por definição, o que não sabe e, assim, representante legítimo do senso-comum.

O senso-comum a priori não conhece, pouco conhece ou conhece canhestramente as regularidades e lógicas que envolvem a interação e isso bem marca os lugares estabelecidos das interações "psi” em seu tipo canônico. Esses lugares, contudo, também são alvo de diluição no processo midiatizado, já que, no espaço do dispositivo interacional da midiatização, saber perito e senso-comum se atravessam em trocas mútuas na possibilidade de voz que a midiatização oferece a ambos. Esse fato pode ser bem ilustrado nas eventuais contestações de Goldin, em suas postulações peritas, por seus leitores a partir do lugar do senso-comum, como vemos:

"SEMPRE LEIO A SUA COLUNA. AO MESMO TEMPO fico intrigada pelo fato de que os temas são sempre de natureza sexual, como se fosse a raiz de todas as infelicidades do homem. Será?! Na minha vida, fiz muitas coisas que não foram motivadas pelo sexo, nem mesmo meu casamento... Casei-me aos trinta anos, com Zé, um colega, fazíamos bons programas, cinemas, teatros, restaurantes... Nosso sexo às vezes me provocava orgasmos, outras não, nunca foi um problema. Com o tempo, as relações foram se espaçando e sua ausência não me ocasionou ciúmes, dúvidas, nem desvalorização, como leio em seus textos. Na verdade, nunca pensei sobre isto! Agora, idosa e viúva, penso com saudade e carinho no meu marido, saudade do que fazíamos, e onde o sexo era insignificante. Pouco sexo nunca me impediu de trabalhar, curtir a vida, criar os filhos e ter boas amizades... Entendo que é importante para dar continuidade à espécie, e é muito gostosa... Mas há outras coisas que também dão prazer, passear, comprar vestidos, bater papo, ler um bom livro etc. Gostaria de saber a sua opinião, inclusive se eu preciso fazer uma psicanálise... Agradeço com admiração. Dora"(Goldin, 2012). 
Além da consulta transformada, aconselhamento transformado e prática pedagógica também transformada se fazem presentes nos escritos de Goldin. Mais que transformados, talvez combinados. É o que percebemos como marca do dispositivo e que produz importante incidência na relação entre saber perito e senso-comum. $\mathrm{O}$ dispositivo interacional que observamos apresenta-se como espécie de aula ou ensinamentos pautados, embora canhestramente e segundo lógicas de funcionamento construídas no espaço já do dispositivo midiatizado, nos saberes "psi" que os legitimam. Uma prática situada no entre espaço da consulta e da divulgação de conhecimento. Tal conhecimento, contudo, diz respeito mais a modos de ser que a conteúdos formativos para capacitação nas práticas em questão.

Temos expressa nesse ponto uma significativa incidência da midiatização quando, em seu contexto, as próprias regras de campo se flexibilizam e ser psicólogo/psicanalista passa a se pautar também - não em detrimento, mas em complementação - pelas representações construídas junto às práticas sociais acerca do que é ser psicanalista e, além disso, do que é a Psicanálise e o que ela faz. Aqui nos deparamos com uma ação de produzir, nas interações ocorrentes nas práticas sociais gestadas no espaço do dispositivo, sentidos outros não apenas sobre a Psicanálise ou o psicanalista, mas que envolvem os saberes e práticas "psi" de um modo geral.

Os sentidos aí produzidos se legitimam nas práticas mesmas e sobre elas incidem, passando a redefini-las e, assim, instaurando o movimento contínuo de transformação que, por sua vez, passa a incidir sobre a episteme da consulta, levando-nos a perceber aspectos de transformação que somente nos permitem falar em consulta enquanto transformada, ou seja, uma produção outra quando comparada ao modelo de consulta corrente em cada um dos ramos de saberes que compõem os saberes "psi” e que a midiatização mesma 
afetou de modo a, em sua ambiência, diluir as especificidades características de cada um desses ramos.

Com isso, surge como experimentação uma construção de consulta que não é mais "tão consulta assim", ao passo em que, para se constituir, não precisa estar nos campos de origem da consulta. Um fazer que se situa no entremeio do campo da Psicologia/ Psiquiatria/Psicanálise e das práticas não-institucionalizadas da sociedade, ou seja, que faz semblante da dimensão do sensocomum. De um lado, as áreas de conhecimento canônicas, de outro, o senso-comum que, apesar de assim se caracterizar, direciona aos processos um olhar a partir da lógica dos campos. Entre os dois, os dispositivos interacionais "psi" midiatizados, responsáveis pela produção, divulgação e representação de um saber "psi” digestivado, deformado, diluído, simplificado que, quando tomado segundo lógicas específicas de campo, tende a ser concebido como "uma passagem em perda”.

\section{Saberes peritos $x$ senso comum}

Para compreender a passagem em perda, precisamos concebê -la como uma perspectiva de olhar que se ergue a partir de referentes de determinado campo que são assumidos por representantes do campo ou extra-campo - do senso-comum -, que o tomam como marcadores legítimos do campo em questão e que não precisam ser do campo, no caso "psi", porque reconhecem as questões sobre as quais podem falar. Assim acontece com as questões acerca da subjetividade que envolvem intimidade, mal-estar, relacionamentos interpessoais e amorosos e sofrimentos psicopatológicos, que são reconhecidas como de competência dos saberes "psi" por especialistas e leigos. Acontece que, quando imersas na midiatização em processo que atravessa a sociedade contemporânea, as questões da 
subjetividade saem desse espaço que é propriamente o campo especializado dos peritos da subjetividade.

Nesse movimento de deslocamento de perspectiva sobre os feitos dos dispositivos interacionais midiatizados que envolvem coisas "psi", se abdicarmos da lógica do campo estabelecido e pensarmos os processos segundo o lugar do senso-comum, percebemos então uma alteração substancial no que está sendo feito pelo funcionamento dos dispositivos. Por esse ângulo de entrada na questão, o saber "psi" anteriormente tomado como digestivado, diluído e eventualmente deformado se torna uma oferta de qualificação frente ao desconhecimento ou conhecimento canhestro acerca das produções enunciativas e práticas do campo "psi" que definem o senso-comum.

Assim, as colunas de Goldin, desqualificadas por gerarem afetações que põem em risco e, por isso, rechaçadas pelos olhares rigorosos dos representantes do campo "psi", podem ser vistas por suas potencialidades de formação e qualificação - obviamente não profissional - de seu público, o qual apreende na interação coisas outras e se modifica. Não se trata de valoração do processo específico, que pode eventualmente ser mesmo criticado, mas de perceber o potencial de transformação da experiência, o que certamente não ocorre sem riscos. Mas só se está atento aos efetivos riscos quando se percebe as transformações em curso, à diferença de uma crítica simplificadora que apenas enxerga a "passagem em perda".

É isso que vai caracterizar e diferenciar os processos ocorrentes no contexto da midiatização em relação à constituição das práticas não midiatizadas. Quando um conhecimento especializado assume uma prática cotidiana, de muitas maneiras a afeta e é por ela afetado. Transpondo a questão para o nosso objeto, temos que o senso comum se qualifica através dos próprios processos psicológicos/ psiquiátricos/psicanalíticos disseminados que, por sua vez, passam 
a ser genericamente - e canhestramente - conhecidos, como é o caso do famoso jargão "Freud explica”. Desse modo, parece surgir um conhecimento - assim como fazeres - da ordem desse campo que não é propriamente o conhecimento de saber especializado. Há também no campo das práticas a produção de saberes e fazeres e isso bem pode ser observado no dispositivo analisado. São percepções como essa que nos levam a sustentar a ideia de consulta transformada.

Se pensarmos a partir de uma relação clássica entre consultor e consulente - um analista e seu analisando - temos também nessa interação uma perspectiva de aprendizagem, embora distinta da aprendizagem institucionalizada do campo regulamentado. $\mathrm{O}$ consulente adquire, nessa interação, um leque de conhecimento psicológico que inclui o processo, o conhecimento de si, a constituição de vocabulário, etc. Bem observamos nos trechos dos escreventes a Goldin um acolhimento do vocabulário, modos de conduta e entendimento de coisas "psi”. A referida interação como lugar de produção de saber é tão legítima que se tomarmos a formação do analista, um dos seus pilares é o processo de análise pessoal, fato que aponta para a importância das práticas nesse sentido.

Ao deambularmos da modelização tradicional e pensarmos os dispositivos interacionais "psi" midiatizados que imprimem deformações à consulta, percebemos que em sua ambiência são produzidos, analogamente à prática interacional da consulta clássica, semelhante ordem de conhecimento sobre assuntos "psi" que não é o conhecimento de saber especializado. Mais que isso, inferimos que os dois fazeres, clássico e midiatizado, mais do que possibilitarem a mesma ordem de conhecimentos em seus espaços adquiridos, podem ser complementares nesse processo.

É possível que uma demanda de saber pelo senso-comum se destine aos dispositivos midiatizados em complementação ao 
dispositivo clássico, como bem pudemos ver nas colunas de Goldin. Podem também ser assumidos pelo senso-comum como substitutivos, como quando acometido de sofrimento psíquico, ao invés de procurar psicólogo, psiquiatra ou psicanalista, o sujeito sofredor escreve ao analista.

O conhecimento prático adquirido nas interações com o dispositivo midiatizado parece qualificar os sujeitos de modo a torná-los uma espécie de liderança de opinião difusa na sociedade para as questões da valoração desse tipo de processo e aí criam uma perspectiva de demanda pelos mesmos, pelas múltiplas razões que elencamos anteriormente. Dessa forma, a Psicologia, a Psiquiatria ou a Psicanálise, em suma, o próprio conjunto de saberes "psi", no seu exercício, se inserem na sociedade e a modificam.

Tal sociedade, por sua vez, passa a gerar expectativas acerca desses saberes e a querer respostas na sua proporção. Para isso, ler as colunas de Goldin pode ser suficiente, como pode também não ser necessário mais. Às vezes são necessários anos de terapia ou análise, complementadas ou não por interações de outra ordem em torno dos saberes "psi", sejam eles midiatizados ou não. Essas variações marcam uma entrada em processos que a rigor não se limitam ao campo "psi" enquanto conjunto de saberes, mas dizem respeito a um conjunto de práticas sociais e seus desdobramentos.

A partir do que expusemos, podemos pensar em uma potencialidade imanente ao agenciamento que se concretiza no dispositivo, na medida em que ele realiza a mediação entre um saber institucionalizado e suas apropriações e representações no senso-comum, que finda por deformar, como já apontamos, tanto o primeiro quanto o último. Porém, deformação não significa necessariamente "passagem em perda", pois o senso-comum, ao se qualificar na interação, ganha em aspectos de formação. Claramente não falamos de formação teorizante ou conhecimento abstrato de campo, tal qual 
constituído pelo conhecimento científico, mas formação para as questões da vida prática, do mundo cotidiano que também acontece na ambiência dos processos em midiatização.

Mesmo assumindo falar para um público composto prioritariamente por sujeitos não especializados nas construções institucionalizadas acerca das questões "psi" - pode eventualmente tal público abranger uma parcela especializada -, Goldin não trabalha com a perspectiva de "passagem em perda" de seu saber de formação. Ao contrário, ele assume a importância das experimentações e estabelecimento de parcerias entre campos como aspecto produtivo para a mídia e a Psicanálise.

Vasta quantidade e diversidade de conhecimentos circulantes na contemporaneidade advêm das interfaces estabelecidas com o campo da prática, que os atores de campos especializados balizam e articulam. O senso-comum é, por definição, aquele que não está habilitado a realizar balizamento ou articulação, ao mesmo tempo em que é também aquele que lida dia a dia, e muitas vezes sem ciência ou sistematização, com o amplo leque de conhecimentos que o circunda. Tal notação nos leva a perceber como improdutiva ${ }^{110}$ a militância pela rígida segregação entre o que é mais rigorosamente do campo e o que extrapola suas fronteiras, na medida em que o que o excede também pode ser produtivo tanto para a sociedade de modo geral quanto para o próprio campo "psi". Com isso, nos deparamos com a questão da função social dos conhecimentos produzidos, bem como das implicações e responsabilidades dos campos com os processos sociais na sociedade em midiatização.

110 Exceto em uma perspectiva de produção de conhecimento epistemológico, teórico ou metodológico de campo. 


\section{Algumas palavras de finalização}

A diversidade de produções em torno das causas "psi” emergentes dos dispositivos interacionais midiatizados é algo que precisa ser considerado como importante produção da sociedade, que afeta o campo psicológico de fora dele ou ainda faz circular afetações do campo causadas pelo próprio campo. O primeiro caso é o que estamos discutindo ao longo desse texto, quando as questões da midiatização põem em circulação enunciados, sentidos e representações que passam a pautar as possibilidades interacionais com os saberes psicológico, psiquiátrico e psicanalítico.

A transformação da consulta sintetiza o que estamos discutindo e exemplifica as afetações do campo por questões externas e internas. Quando argumentamos que, no contexto da midiatização em acelerada processualidade, a consulta se transforma, a princípio estamos argumentando que nessa ambiência a consulta se transforma. Esse é o primeiro viés de transformação. Contudo, quando isso acontece e esse tipo de consulta modificada é posta em circulação nos processos sociais, ela produz reverberações sobre os sentidos e construções tradicionais a seu respeito e finda por produzir deformações mais amplas que extrapolam o espaço midiatizado, permitindo afirmar que quando a consulta se transforma, o próprio campo recebe a incidência dessa transformação - transformação em processo, em aberto, constituída no movimento das interações continuamente forjadas no seio de dispositivos insurgentes, e que bem sintetiza as considerações sobre os dispositivos interacionais "psi" na sociedade em midiatização. 


\section{Material de pesquisa}

GOLDIN, Alberto. TENHO VINTE E CINCO ANOS, HÁ DOIS CONHECI. Jornal O Globo, Rio de Janeiro, 27 de outubro de 2010.

. FAZ UM ANO QUE EU E ROBERTO TERMINAMOS.

Jornal O Globo, Rio de Janeiro, 13 de novembro de 2011.

. SOU MELHOR DEBATENDO SINTOMAS VISÍVEIS.

Jornal O Globo, Rio de Janeiro, 20 de novembro de 2011.

. TENHO OBSERVADO EM MIM UMA CONSTANTE.

Jornal O Globo, Rio de Janeiro, 01 de janeiro de 2012.

. GOSTARIA DE PEDIR SUA OPINIÃO. Jornal O Globo, Rio de Janeiro, 29 de janeiro de 2012.

. TENHO 30 ANOS, SOU BEM SUCEDIDA. Jornal O

Globo, Rio de Janeiro, 25 de março de 2012.

. SEMPRE LEIO A SUA COLUNA. AO MESMO TEMPO.

Jornal O Globo, Rio de Janeiro, 13 de maio de 2012.

. TENHO 27 ANOS E PELA PRIMEIRA VEZ NA VIDA.

Jornal O Globo, Rio de Janeiro, 27 de maio de 2012.

. Entrevista pessoal a Monalisa Pontes Xavier, feita para a tese de doutoramento, 2013. 


\title{
Suíte no 9
}

\section{“Dispositivos 'psi' midiatizados", de Monalisa Pontes Xavier}

\author{
José Luiz Braga
}

\begin{abstract}
A coluna "Vida Íntima", analisada pelo capítulo, recebe sobre sua singularidade e suas lógicas a incidência de contextos diversificados: a interface psicologia/comunicação; a midiatização; a subjetivação na cultura; e o tensionamento contemporâneo das especialidades. Devolve sua resposta aos contextos na forma de uma tentativa que é, ao mesmo tempo, experimentação interacional e diagnóstico do estado de coisas - na sociedade e nas questões de ordem "psi”. Monalisa, com formação em Psicologia e em Comunicação, observa a imbricação desses ângulos de incidência na sociedade e no seu objeto de estudo.

Assim, a questão das interfaces se põe em vários ângulos. O primeiro é o fato de - na própria pesquisa, do campo da Comunicação - estarmos interessados em lançar um olhar comunicacional sobre objetos constituídos em outras áreas de conhecimento, pelo que eles comportam de processualidade interacional. A consulta é um objeto psicológico de pleno direito - nós o olhamos, no entanto, para buscar aí seus processos comunicacionais. Que estes sejam modalizados pela relação terapêutica não pode ser afastado: porque é esse modo interacional que queremos aí observar.

Mas não é apenas o olhar investigativo que se decide "de interface": o próprio objeto se mostra como tal quando, em sua ação transformadora de consultas canônicas, modifica o dispositivo da consulta, e essa mudança - de ordem comunicacional - tensiona a
\end{abstract}


substância, os resultados possíveis e as próprias bases de sua racionalidade psicológica.

O caso examinado se põe como de interface não porque entra na mídia ou sofre sua influência - mas porque age comunicacionalmente, experimenta a partir de seus cânones psicológicos, e os redireciona em busca de "outra interação", ainda tentativa. Buscando outra interação, faz ver que aqueles cânones são também modos de interagir, sujeitos, desde a origem, a um possível olhar comunicacional: são as formas de interação que, nas condições vigentes no campo psicológico, se construíram com maior pertinência para as questões envolvidas, e foram assumidas como mais adequadas para encaminhá-las.

Tais desafios e tentativas sociais se fazem em um mundo que se transforma em dois processos relacionados: a tendência de crescente midiatização da sociedade; e o desenvolvimento de uma cultura (da qual a própria midiatização é um elemento relevante) em que os modos e processos de subjetivação ocorrem em ambientes expostos e publicizados, mais talvez que nos espaços íntimos da privacidade.

Monalisa abre seu texto referindo a midiatização da sociedade, e mostra que "suas lógicas passam a afetar o funcionamento [das práticas sociais contemporâneas], bem como as mais variadas experimentações e invenções que se forjam em sua ambiência". Situa assim seu objeto - dispositivos interacionais "psi" midiatizados - como agenciamentos de tais práticas com a mídia. Não se aborda, aí, a midiatização como simples influência da mídia sobre outros setores sociais, mas sim pelos agenciamentos experimentais que articulam lógicas de outros setores e campos com lógicas de mídia. As experiências sociais são os verdadeiros processos e lógicas comunicacionais que interessa pesquisar.

A coluna de Alberto Goldin (assim como outros dispositivos psi midiatizados) corresponde a uma verdadeira experimentação, 
com invenção de lógicas interacionais para produzir interações de ordem psicológica em condições de mídia. É por isso que os diversos condicionantes tratados pelo texto não são propriamente "lógicas de mídia”, mas sim lógicas socioculturais de uma sociedade em midiatização. Não é apenas por "estar na mídia" que a coluna Vida Íntima é um dispositivo psi midiatizado - mas também por lidar, prática e refletidamente, com tais condicionantes socioculturais em midiatização.

A autora observa uma incidência direta dos processos socioculturais da midiatização nos modos de subjetivação da sociedade - em espaços externos e independentes das práticas midiatizadas de ordem clínica. Os processos de exposição pública, solicitações múltiplas recebidas do ambiente, a dispersão de estímulos de todo tipo (e cobranças, promessas e miragens), passam a exigir outras "operações de sentido em torno do mal-estar, do sofrimento, da angústia, da solidão, dos relacionamentos interpessoais e de uma variedade de desencaixes subjetivos no contemporâneo".

Isso faz perceber que as demandas se modificam - e que as respostas e os processos muito canonicamente estabelecidos se tornam insuficientes. Na falta de códigos interacionais estabelecidos para os novos desafios, os processos interacionais serão tentativos, para gerar dispositivos que busquem sintonizar a demanda e elaborar novos padrões mais ou menos estáveis. Isso não só ocorre no ambiente midiático (embora aqui de modo mais visível), como também em direta incidência na consulta "estabelecida", que se vê igualmente desafiada.

Outra peculiaridade dos dispositivos midiatizados é que parecem favorecer articulações e tensionamentos entre lógicas especialistas de campo e modos práticos do senso comum. Monalisa observa que "se [...] pensarmos os processos segundo o lugar do senso comum, percebemos então uma alteração substancial no que 
está sendo feito pelo funcionamento dos dispositivos". Isso implica uma descentração do olhar especializado - não para abdicar de sua especialidade, mas para poder interagir com o outro, percebendo suas lógicas e se deixando desafiar por elas. Trata-se, aí também, de uma questão essencialmente comunicacional.

Experimentações são necessárias, dadas as condições e os limites do lugar e dos processos gerais em que a interação deve ocorrer. $\mathrm{O}$ desenho do dispositivo deve ao mesmo tempo atender a fundamentos do conhecimento constituído e seus objetivos seminais; às demandas por parte das pessoas que buscam na coluna alívio ou elucidação; e às características do meio (no caso, verbal escrito, não presencial, diferido e difuso, portanto de público plural). O processo é, além disso, serial e "rápido". Isso produz descontinuidade no diálogo com cada consulente, apenas começado; mas gera outra continuidade, resultante da substituição e cumulação de casos diferentes. Com tais experimentações, e na encruzilhada dos contextos referidos, o colunista trabalha com atravessamentos e imbricação de processos, direcionando-os em favor de seus objetivos "psi".

A consulta de "Sônia" é exemplar desses processos: a correspondência à coluna vem complementar leituras, terapia, recurso a religião. Dado o lugar de diálogo assumido, o analista não pode descartar in limine os demais espaços de interação imbricados na fala, não pode ter a pretensão de contrapor uma fala exclusivamente especializada - simplesmente articula sua fala nesse ambiente de convergência que é aquele de onde emerge a consulta: porque é aí que se dá o diálogo.

Monalisa mostra que "se há procura por mais um espaço de expressão de conteúdo subjetivo, de sofrimentos, de mal-estar, pressupomos que algo escapa ao espaço da clínica, marcando a insuficiência do padrão canônico". Nesse contexto, a fala do analista também se hibridiza. $\mathrm{O}$ texto mostra que outros campos 
"mesclados nos escritos são a Literatura, a Psiquiatria, a Educação e o senso-comum". Goldin vai "ensaiar um pouco de Filosofia, de Literatura, optar pela Estética, ser jornalista ou retornar para o lugar de analista".

No processo, o analista aceita o terreno dos consulentes como espaço em que a interação pode ocorrer. Essa aceitação do âmbito de senso comum como lugar de diálogo é uma valorização da escuta - ao mesmo tempo um valor da análise e um valor da comunicação. É nesse espaço que se evidencia a "relação estabelecida entre as perspectivas do saber especialista e das construções do senso-comum", assim como a constituição de fronteiras porosas entre esses dois âmbitos. Assim como, nessa zona de porosidade, o amador pode se tornar mais esclarecido, o campo especializado pode abrir processos menos rigidamente comandados por lógicas de sistema, e ter maior abertura comunicacional para processos agonísticos - viabilizando avanços de conhecimento.

Observar distinções interacionais entre o dispositivo estabelecido, canônico, e aquele em processo experimental ajuda a compreender sentidos da "consulta transformada". O processo se desloca da relação protegida entre consulente e terapeuta para a realização de um diálogo diante de terceiros.

$\mathrm{O}$ que era um diálogo propriamente dito modifica-se para uma tríade de participantes, o que transforma a interação. Para o analista, implica uma duplicação da interlocução - com aquele a quem fala; e com outros, aos quais mostra o primeiro diálogo - com uma sugestão implícita: observem essa relação entre uma demanda e um modo de abordá-la. Assim, a fala direta é portadora de uma demonstração - de temas, de demandas, de tipo de escuta, de inferências de ordem psicanalítica.

Para o público leitor, uma diversidade de ângulos é oferecida. Primeiro, e conforme o depoimento do analista, a possibilidade de 
encontrar sofrimentos e demandas próximos aos seus, assim como reflexões sobre estes. Mas além disso - dada a variedade de casos sucessivamente tratados - o panorama de "desencaixes subjetivos no contemporâneo", lhes oferece um quadro ampliado onde podem articular, mais que seu próprio sofrimento, seu perfil de autoconhecimento - pelas sintonias, pela comiseração, mas também por distanciamento ou ironia. Sempre conforme o senso comum, o terceiro que presencia o diálogo recebe matéria de reflexão e a possibilidade de ver situações diante das quais é possível "falar sobre" e incorporar percepções. Essa fala em terceira pessoa parece ser uma das possibilidades concretas da aprendizagem pública como processo de formação de um senso comum qualificado.

Finalmente, para o consulente, se observa talvez uma das maiores diferenças com relação à consulta estabelecida - não mais protegida pela relação privilegiada cliente-terapeuta. Seria esta, talvez, uma das razões principais pelas quais o campo psicológico vê com reticências determinadas experiências extrafronteiras. Mas essa relação triádica, hoje, apresenta ao mesmo tempo um sintoma e uma questão a resolver pelo conhecimento. Mais do que simplesmente ter seu caso exposto e tratado diante de terceiros, a exposição faz parte do caso. Como consulente, não quero apenas ouvir do analista uma fala que me dê pistas para compreensão ou alívio quero também mostrar ao mundo o que me identifica e caracteriza, como modo de ser e como sofrimento. Longe de ser descartável, essa demanda faz parte das questões do indivíduo na contemporaneidade - tem que ser compreendida, refletida e elaborada. Serge Tisseron (2001) aborda essa questão da exposição:

Proponho chamar de « extimidade $\gg$ o movimento que leva cada um a expor uma parte de sua vida íntima, tanto física como psíquica. Esse movimento passou muito tempo despercebido, 
mas é essencial ao ser humano. Consiste no desejo de comunicar sobre seu mundo interior. [...] Se as pessoas querem exteriorizar certos elementos de sua vida, é para melhor se apropriar deles os interiorizando de outro modo, graças às trocas que suscitam com os próximos. A expressão do eu íntimo [...] se faz a serviço da criação de uma intimidade mais rica (Tisseron, 2001, p. 52 L'intimité surexposée - trad. nossa).

Nesse sentido, ter sua correspondência selecionada e exposta aos leitores, merecer uma reflexão do analista, faz parte dos processos da consulta transformada - mas é também uma questão comunicacional que merece as reflexões de nosso campo, na busca de compreender os dispositivos e circuitos que, para além da experiência dos especialistas do campo "psi”, caracterizam tentativas processuais da sociedade para lidar em interação com seus próprios requerimentos e desafios de coexistência. 
Parte III

Conclusões 


\title{
Conclusões: Inferências transversais
}

\author{
José Luiz Braga e Maria Regina Zamith Calazans
}

\section{Introdução}

Só há sociedade porque nos comunicamos. A comunicação aparece como processo de geração e de intermediação entre as pessoas e as instituições. Apenas porque nos comunicamos as sociedades podem incidir sobre os indivíduos, até certo ponto moldando sua subjetividade, suas interações uns com os outros e sua participação na própria sociedade. Nesse espaço, os dispositivos interacionais estabelecidos são facilmente apreendidos, segundo as lógicas de enquadramento socialmente produzidas ${ }^{111}$.

A comunicação parece, então, simplesmente ocorrer nesses ambientes mais ou menos estabelecidos institucionalmente (lembrando que a linguagem verbal é também uma instituição). É menos perceptível o fato de que os andaimes, os materiais e os processos (menos aparentes após a construção pronta), foram montados

111 Na sociedade contemporânea, estas lógicas de enquadramento são frequentemente conceituadas pelas CHS, em função de objetivos explícitos dos episódios interacionais culturalmente incorporados, e/ou de instituições mais presentes no contexto de sua ocorrência. 
e desenvolvidos através da comunicação entre os seres humanos, em momentos e andamento históricos. As instituições foram e são constituídas por táticas e estratégias comunicacionais: tentativas.

O que se construiu - e continua sendo construído - certamente nunca corresponde exatamente ao que se tentava estabelecer, dada a insuficiente de precisão nos processos e sobre os resultados da comunicação humana; e portanto por sua característica tentativa. Mas a sociedade certamente decorre desses processos - ou do conjunto tensionado entre estes e sua inserção em contextos apenas parcialmente favoráveis (quando não francamente hostis).

A comunicação se caracteriza como o processo que articula sociedade e ser humano, permitindo a mútua produção entre indivíduos, em sua singularidade pessoal diversificada, internamente fracionada; e todas as instâncias supraindividuais, organizadas ou não, estabelecidas e sistematizadas, tentativamente em ação, ou mesmo no caos da indefinição. Desde a simples presença do "outro" - do reconhecimento da alteridade - até os sistemas sociais mais complexamente agenciados, a sociedade incide sobre os indivíduos pelos processos comunicacionais. Ao mesmo tempo, a sociedade é constituída, pelo esforço constante e diversificado dos indivíduos para se relacionar e agir em conjunto.

É claro que, ao nos comunicarmos, em quaisquer circunstâncias, estamos completamente enredados nas teias de nossa subjetividade e, ao mesmo tempo, solicitados e direcionados pelas injunções dos contextos múltiplos que a inserção nas coisas instituídas impõe. O que chamamos de dispositivo interacional está em toda parte, nos processos mais instituídos e rotinizados, assim como no cotidiano mais imediato ou subjetivo de cada pessoa, disponibilizados pelo ambiente cultural, na forma de práticas de interação habituadas. 
Mas o lugar em que a comunicação se faz mais explícita, mais perceptível para o olhar inquiridor que busca compreender, são as situações em que, malgrado as teias e as injunções, a comunicação não segue apenas caminhos mais sulcados, mas se experimenta. Certamente é em níveis intermediários que mais provavelmente percebemos os processos comunicacionais $\mathrm{em}$ sua ação propriamente geradora. Talvez porque o instituído e o subjetivo se tensionam mutuamente; ou porque os dois lados ofereçam, concomitantemente, suas imposições e zonas vazias a preencher.

Nesse espaço, o gesto tateante da interação, experimental, incerto, canhestro, se manifesta de modo mais explícito. É também o espaço em que, de antemão, o pesquisador se sente mais inquieto pela não clareza imediata, mais estimulado pela vontade de compreensão: o que é que está ocorrendo ali? Questão posta, justamente, porque as interações não se resolvem na obviedade das coisas que, de tão rotineiras e previsíveis, parecem inteiramente sem mistério, totalmente conhecidas.

Certamente, reconhecemos que as funções, digamos reiteradoras, são também importantes, por assegurarem uma estabilidade sem a qual não é possível atender ao cotidiano. Entretanto, mesmo onde um dispositivo se mostra fortemente estabelecido e vigente, a melhor maneira de perceber suas lógicas é a de procurar inferir sua origem e buscar compreender, aí, os movimentos estratégicos que acabaram por desenvolver um padrão, que passou então a ser acionado.

Não por acaso, os nove estudos empíricos deste livro situamse nesse espaço do tentativo e do "a compreender": na injunção (institucional e subjetiva) de fazer pesquisa, os pesquisadores são movidos por aquilo que os intriga. Estão aí incluídos tanto o episodio interacional em construção, que mostra ainda seus andaimes 
e de que se pretende perceber as lógicas processuais; como o episódio aparentemente banal e evidente, já conhecido em alguns aspectos, mas que se submete a um olhar em busca de outros ângulos de compreensão.

O que devemos agora fazer, para a conclusão do exercício heurístico que reúne os autores deste livro, é observar os sistemas de relações expressos no caso a caso, sob esse aspecto em que se pode observar, por um ou por outro ângulo, processos comunicacionais se constituindo tentativamente. Ou seja: dentro das teias da subjetividade e das injunções institucionais, mas também com uma margem de elaboração em aberto, que pertence ao próprio exercício comunicacional.

Para esse trabalho, adotamos cinco ângulos abrangentes que organizam premissas apresentadas nos dois capítulos iniciais e sistematizadas no terceiro capítulo: (a) comunicação como encontro entre diferenças; (b) códigos e inferências; (c) relações entre episódios comunicacionais e seus contextos; (d) produtos e circuitos; (e) dispositivos interacionais.

Este último ângulo, "dispositivos interacionais", aparecia na Parte I em posição inicial - uma vez que é o elemento eixo da heurística. Agora o comentaremos no final da sequência, porque essa posição favorece sua caracterização como "sistema de relações", de que os demais ângulos fazem parte.

O procedimento para articulação desses ângulos da heurística com os nove casos - conforme expostos pelos respectivos autores - corresponde a um movimento recorrente de ida e volta entre as duas dimensões, reflexiva e empírica.

Partindo da heurística, reestudamos os textos sobre os casos, para inferir o que deles emerge em cada um dos cinco ângulos. Partindo do que os casos mostram, em sua modelização, destacamos especificidades e variações que enriquecem a reflexão abstrata relativa aos ângulos e à heurística. Esse encaminhamento, várias 
vezes reiterado, corresponde à proposta de Lucien Goldmann, que propõe inscrever o objeto investigado nas estruturas significativas em que se inscrevem, "démarche que pressupõe um vaivém permanente da parte ao todo e vice-versa” (Goldmann, 1967, p. 102).

\section{Comunicação - interação entre diferenças}

Assumimos a comunicação como o trabalho de relacionar diferenças em torno de algo já compartilhado porque, percebendo a alteridade humana como irredutível a um padrão único, é preciso não só fazer conviver a diferença mas, com ela e apesar dela, existir em conjunto. Para além da identidade biológica da espécie, o ser humano parece ser especializado em gerar variações e diversidade - e percebê-las. Nós nos percebemos comuns na espécie, mas singulares na distinção com o outro. Precisamos acionar o que já é compartilhado, para enfrentar as diferenças que impedem o agir articulado. $\mathrm{O}$ jogo comunicacional se faz nas variações de modos e composições entre a diferença e a semelhança. Isso fazemos - com clareza ou imprecisão.

Os participantes podem diferir nos modos de ser, nas especialidades profissionais, na experiência, nos acervos de conhecimento, nas posições sobre as coisas do mundo; por sua inscrição em campos sociais, por seus interesses gerais ou relativos ao episódio interacional específico. Em qualquer caso, a comunicação é o jogo possível da alteridade.

As diferenças substanciais, que os pesquisadores do grupo mostraram nos casos estudados, aparecerão nos itens subsequentes na forma de distinções de códigos acionados, de contextos, de circuitos. No presente item, observaremos os modos pelos quais os participantes encaminham as diferenças. Nos estudos de caso, constatamos que, em algumas situações, as diferenças não trazem 
maiores dificuldades - podem ser esquecidas por distanciamento ou indiferença. Em outras situações, as diferenças é que pedem a interação, para buscar simetria, ou para organizar a assimetria em relações complementares, podendo exigir negociações mais ou menos complexas para viabilizar interesses comuns. Finalmente outras, postas em contato, levam a conflito, velado ou aberto. Podemos organizar, assim, três conjuntos de processos: em confluência, em conflito aberto, ou em negociação.

\section{Diferenças confluentes}

Quando as diferenças se encontram em circunstâncias tais que não produzem distanciamento, se ajustando em harmonia complementar, a comunicação pode corresponder à descoberta euforizante das próprias diferenças. Mas as interações confluentes não implicam apenas tal harmonia. Eventualmente, o próprio interesse em articular diferenças para torná-las produtivas move a interação. Já nas situações de ação social em quadros complexos, ou para produção de materiais, é requerida uma conjunção de participantes com especialidades e práticas diversificadas, para compor soluções ou produtos - dispositivos variados modelizam tais interações em processos ditos "de equipe". Paralelamente, nas diferenças evidentes entre criadores de um produto cultural, de um lado, e os participantes de circuitos a quem o produto é direcionado, é possível encontrar uma busca de sintonia mútua. Em determinados episódios, ainda, diferenças podem ser deixadas de lado, em favor de um objetivo ou uma característica comum que reúne os participantes.

Outros episódios e dispositivos envolvem relações decididamente assimétricas - é das diferenças mesmo entre os participantes que se espera uma comunicação pragmaticamente significativa. Como, por exemplo, nas relações entre médico e paciente; entre 
professor e estudantes; entre pais e filhos. A possibilidade de confluência ou, ao inverso, de interações conflitivas, depende dos processos e da inteligência interacional dos participantes.

No dispositivo Márcia Franz, em torno da liderança de orientação reflexiva, os diversos participantes, embora inscritos em posições e com competências variadas, se articulam em harmonia, movidos por um mesmo tipo de preocupações sobre as ocorrências da atualidade e sobre o sistema jornalístico que informa ao público aquelas ocorrências. Nesse caso, as diferenças se exercem sobretudo no sentido de trocas enriquecedoras. A interação se caracteriza por processos de aprendizagem e formação que combina perspectivas de senso comum e competências especializadas em acionamento mútuo.

Nos casos da minissérie e do filme documentário - como em toda produção audiovisual relativamente complexa - constatamos articulações produtivas entre diferentes formações e competências específicas. Esses processos de produção desenvolveram práticas já bem estabelecidas para sua confluência no que chamamos de trabalho de equipe, fazendo compor tarefas diferenciadas e complementares.

$\mathrm{O}$ processo produtivo de uma minissérie histórica pede uma articulação complexa de grande variedade de especialistas. O objetivo comum de montagem de uma narrativa audiovisual implica um ajuste fino em meio a essa diversidade - de que aparece ao público apenas o resultado final produzido.

No Acercadacana, a confluência ultrapassa o trabalho da equipe, para abranger uma sincronia produtiva entre a família entrevistada, os responsáveis pela feitura do documentário e os circuitos cinematográficos que os acolhem.

Os processos de equipe aparecem igualmente nos diversos casos de noticiadores noticiados - aqui, naturalmente direcionados pela estrutura empresarial e profissional da televisão. Nessa mesma 
lógica, a sintonia com os espectadores corresponde a uma resposta das emissoras a expectativas de públicos diversificados - seja com base em indicações hoje viáveis por informações e opiniões em circulação nas redes sociotécnicas; seja a partir de previsões sobre o interesse de espectadores.

Em todos esses casos em que há geração de um produto, este vai encontrar também uma diversidade de interlocutores (na "recepção"). Essas diferenças se manifestam ora como interpretações diferenciadas dentro de um mesmo circuito; ora como desenvolvimento de circuitos diversos - com apropriações redirecionadas de um mesmo produto.

No caso dos movimentos de 2013, encontramos diferenças significativas entre os participantes - de objetivos específicos, de abrangência da reivindicação, de inscrição social, de alvos das próprias reivindicações. A proximidade que viabiliza sua participação conjunta é o processo reivindicatório - as demais diferenças se tornam irrelevantes para a interação.

$\mathrm{O}$ modo de articulação, pela agregação euforizante das diferenças, viabiliza na experiência a farta variação interna de reivindicações e de modos de expressá-las. Durante certo tempo, uma harmonia "natural" dentro da aparente cacofonia realiza uma integração, afastando tensões internas possíveis entre os diferentes. Por outro lado, esse processo mesmo de confluência entre as reivindicações diversas impede uma concertação planejada de prioridades e de encaminhamentos para concretização de resultados pretendidos.

O tipo de interação cooperativa na coluna Vida Íntima mostra ainda outro modo de articulação de diferenças. Aqui, a assimetria é estrutural - ou seja, compõe a própria possibilidade da comunicação entre a demanda que pede alívio e elucidação, e a voz especializada que responde. Essa diferença, que encontra padrões interacionais 
canônicos no campo psicológico, passa a ser tratada em outras linhas de ação interacional - o que traz à cena um terceiro diferenciado, o público que "assiste" à primeira relação, tornando o processo triádico, pela inclusão da diversidade interpretativa nesse circuito. Outras articulações diversificadas podem se desenvolver nesse espaço.

\section{Diferenças em conflito aberto}

No extremo oposto às diferenças confluentes, encontramos as circunstâncias de conflito aberto entre diferentes participantes da sociedade - que impedem a interação direta entre as posições divergentes. Mas, se não há interação direta, as ações de parte a parte implicam consequências, levando a lances de ação que produzem incidências mútuas - repercutindo em novas ações. Podemos então perceber que o conflito aberto, implicando uma ausência de qualquer negociação, leva a um processo de comunicação indireta. Encontramos em nosso conjunto empírico dois exemplos desse processo.

Nos casos de vazamento de dados secretos e seus processos de circulação, o conflito marca as diferenças entre os responsáveis pelos circuitos do segredo e os ativistas que buscam desenvolver circuitos de esfera pública. As posições em conflito acionam, de um lado, legislações restritivas, do outro lado, ações de desobediência civil e contestação de procedimentos e das leis que os sustentam com consequências de parte a parte.

Também no documentário Acercadacana, o conflito é a tônica da diferenciação entre os participantes do filme documentário e os setores econômico-políticos responsáveis pela opressão. Nessa situação, cada lado do conflito age nos circuitos interacionais mais favoráveis a sua posição, não interagindo entre si. Restam, de um 
lado, a violência, física e de ação política; do outro lado, resistência e a possibilidade da denúncia.

\section{Diferenças em negociação}

No intervalo entre os processos mais ou menos harmônicos e as repercussões indiretas do conflito aberto, há toda uma variedade de possibilidades de negociação entre diferentes. $\mathrm{O}$ espaço da negociação é um dos âmbitos de comunicação que comporta grande diversidade de processos. Há sempre objetivos complementares entre participantes, que levam à negociação, e objetivos específicos de cada parte que podem levar a conflito ou tensionamentos mútuos. Muitos estudos no âmbito de todas as CHS se voltam sobre a questão "negociação" - que podem ser complementados por análises expressamente comunicacionais. Encontramos em três dos casos estudados tais negociações, em graus variados de tensionamento e cooperação.

As diferenças entre os participantes da experiência TV/ Comunidades mostram ao mesmo tempo um conjunto de objetivos articulados - que os faz cooperadores em sentido pleno - somado a um tensionamento dentro dessa cooperação, decorrente das práticas e procedimentos incorporados de parte a parte.

Entre a tensão e a cooperação, o processo resulta em certa instabilidade, entretanto instigante como experiência comunicacional. Não se trata nem de ver um dos lados deslocar o outro (como pode ser o caso em interações mais conflitivas), nem de eliminar as diferenças por equalização de processos. Mas sim de, mantidas as diferenças, desenvolver padrões de interação que articulem as duas lógicas de ação.

$\mathrm{Na}$ defesa da esfera pública contra a vigilância, algumas das experiências produzem também esforço cooperativo negociado, 
embora com tensionamento mútuo - nas negociações entre ativistas de uma circulação aberta e jornalistas, responsáveis canônicos pelos processos de difusão informativa. Essa diferença gera tensionamento, mas ao mesmo tempo viabiliza modificações em procedimentos jornalísticos e cria espaços eventuais para a circulação pretendida. A potencialidade e os processos de transformação são naturalmente muito diversos, no acionamento e na fricção entre essas diferenças.

Nos fluxos informacionais em redes sociotécnicas que atravessam o campo jornalístico, os tensionamentos (e eventuais ajustes jornalísticos) ocorrem entre a mídia empresarial e os processos informacionais e de opinião diversos viabilizados por aquelas redes. Parte das diferenças se dilui, por ajustes desenvolvidos no campo jornalístico. Outra parte pode resultar em dissensão explícita (como nas iniciativas em que antigas fontes passam a informar diretamente por meio de redes sociotécnicas); outra parte, ainda, leva a geração experimental de outros e outros processos de circulação de informação com objetivo de sistematização - seja por iniciativa direta dos próprios setores interessados nas informações; seja por uma retomada do chamado jornalismo alternativo, não empresarial.

Finalmente, é possível ainda assinalar diferenças que simplesmente não entram em contato - gerando espaços diferenciados no ambiente social geral. A complexidade crescente da sociedade tem gerado setores e ambientes em relativa autonomia mútua, minimizando o encontro de alguns setores com outros que, se postos em contato estreito, produziriam desentendimentos de enfoque. Esse distanciamento corresponde a uma espécie de "solução pela não comunicação". Por outro lado, aquela mesma complexificação, com a multiplicação de circuitos, leva com alguma frequência à 
produção de contatos não previstos entre esses "mundos diferenciados" - criando problemas comunicacionais singulares que vão, por sua vez, estimular novas necessidades de geração de dispositivos interacionais, como veremos no item final deste capítulo. 


\section{Códigos em tensionamento e transformação}

Os elementos pertinentes padronizados em um dispositivo interacional (os "códigos") dão suporte à interação, que se complementa pelo trabalho inferencial dos participantes, induzido pelo dispositivo habitual ou estimulado pelo episódio. Com produção mútua entre código e inferência (o primeiro exigindo o segundo para completar sua potencialidade; o segundo, na medida de seu sucesso singular, passando a se reiterar e se tornando um padrão), é importante insistir sobre a necessidade do código para a comunicação; e de seu tensionamento transformador pela inferência, para que a comunicação se realize na situação singular do episódio assim como na lógica dos dispositivos estabelecidos.

Os episódios e dispositivos aqui estudados - assim como todo o trabalho interacional que viabiliza a comunicação humana - se desenvolvem sobre uma camada de compartilhamento generalizado, que corresponde à cultura prevalente em uma sociedade. Esse é também o espaço do senso comum. Dispomos todos de códigos culturais gerais internalizados, geralmente facilitados por uma mesma língua, tendo passado por uma socialização primária na família e grupos de convivência próxima, desde crianças; e de socialização secundária, sobretudo na escola, nas relações de vizinhança e em grupos de atividades diversas,

A partir dos códigos culturais ${ }^{112}$, todas as ações e interações, as mais especializadas, idiossincráticas, setoriais, inovadoras ou rotineiras, recortam suas especificidades. Paralelamente vamos inventando, redirecionando, solapando e assoreando processos, conforme o que seja requerido pelos objetivos, desejos e neces-

112 Lembrando que estes foram e são, constantemente, criados e recriados por processos comunicacionais. 
sidades dos participantes. Esse processo de tensionamento e modificação se faz sobre códigos especializados e sobre os próprios padrões culturais, mesmo quando muito abrangentes e arraigados.

De certo modo, a existência social corresponde a essa constante tensão entre códigos comunicacionais diversos - tentando fazê-los conviver mesmo quando contraditórios; contestando-os pela proposição de outros códigos; buscando aperfeiçoá-los ou destruí-los; ou simplesmente desgastando-os por seu uso em situações diversificadas. $\mathrm{O}$ âmbito cultural não é, portanto, espaço de harmonia e confluência de códigos - é antes o espaço em que estes se fazem e se desfazem.

No conjunto de casos estudados neste livro, encontramos toda uma variedade de "áreas de codificação". Ora percebemos espaços específicos dentro dos quais "as coisas funcionam", ora âmbitos de tensionamento, em que ocorrem esforços de ajuste ou sérios conflitos entre códigos diferentes mais ou menos engastados na cultura.

Os códigos sociais - mesmo os mais estabelecidos na cultura - não são totalmente abrangentes nem coplanares uns com outros: não se entrosam perfeitamente, nem são suficientes para dar conta da variedade de situações a que podem, entretanto, dizer respeito. Assim, encontramos também um trabalho de ajustes, de tentativas, resultantes de um trabalho inferencial dos participantes, e que é exigido pelo dispositivo e/ou pela conjuntura específica dos episódios.

Podemos constatar, na observação dos casos empíricos, que grande parte das diferenças entre participantes - observadas no item anterior como condição de base trabalhada pelo gesto comunicacional - corresponde a adesões a diferentes códigos por parte dos interagentes de um episódio. 


\section{Códigos irredutíveis}

No confronto entre os dois macrocódigos políticos, o da defesa da segurança do Estado e o da transparência na esfera pública, o que encontramos na abordagem estudada é uma irredutibilidade de códigos de parte a parte.

Os códigos que enfatizam a vigilância e o segredo adotam um processo de exclusão de outros participantes. Dada essa exclusão comunicacional, a sociedade diversificada fica impedida de interagir e de defender seus interesses e posições em lógica de esfera pública.

A impossibilidade de processos inferenciais entre as duas áreas é correlata à ausência de espaço para negociação. Assim, o trabalho inferencial se manifesta sobretudo na defesa da transparência, pelos processos de articulação de ações sociais muito diversas na viabilização de um espaço de publicização. É nesse esforço interacional que se desenvolve uma negociação entre os códigos canônicos do jornalismo e os códigos da transparência social, com a expectativa de viabilizar dispositivos específicos de maior disponibilidade para os objetivos da esfera pública.

No episódio Acercadacana, igualmente irredutíveis são os códigos interacionais relacionados à disparidade econômica, acionados como opressão recusadora dos processos, comunicacionais, da negociação. Perante o processo de denúncia, "respondem" apenas com uma normatividade jurídica favorecedora do mais forte.

\section{Recodificações}

Em contraposição ao enfrentamento entre códigos irredutíveis, as inferências de ajuste a situações específicas incidem sobre códigos acionados, gerando recodificações. 
Os códigos acadêmicos e profissionais encontram no dispositivo em Facebook estudado um exemplo de articulação. Não são códigos automaticamente harmoniosos: embora o trabalho jornalístico seja inicialmente formado pela academia, as diferenças da prática profissional levam à distinção de códigos. $\mathrm{O}$ participante amador não aciona conceitos teóricos, mas sim códigos pragmáticos da cultura geral e da cidadania para interpretar a informação e seus processos. No interação conversacional, porém, os diferentes participantes se mostram disponíveis para transitar entre códigos, viabilizando derivações recodificadoras.

Um aspecto a ser sublinhado, na minissérie histórica, é que códigos de um âmbito social - no caso, os do entretenimento se mostram recodificáveis, por processos inferenciais, para outras interpretações e acionamentos. $\mathrm{O}$ fato de que a narrativa, em seus aspectos afetivos, de fruição estética, do mundo da vida, se articula em ambiente reconhecível como histórico, viabiliza a percepção dessas referências contextuais. A aprendizagem de elementos da história em associação com a vida vivida favorece o conceito de cidadania.

A criação cinematográfica desenvolve seus processos próprios com perspectivas abrangentes e diversificadas. Assim como outros setores de criação e crítica, o cinema se volta sobre a variedade de "mundos sociais" tensionando os códigos próprios destes ambientes e incidindo diretamente sobre eles pela perspectiva estética, interpretativa, analítica e crítica. Uma das dinâmicas principais dessa criação é sua capacidade inferencial de interpretar e elucidar. Uma das incidências possíveis, fazer rever os códigos da área observada.

Malgrado a irredutibilidade codificada da opressão econômica (e do apoio jurídico que angaria), o esforço da denúncia e da argumentação demonstradora da opressão social, no Acercadacana, 
é o de obter recodificações estimulando a sociedade em favor da equidade e da justiça. A ação empreendida para enfrentar os códigos econômicos instituídos depende de inferências sociais nessa direção, podendo estimular competências interpretativas dos espectadores.

\section{Tensionamentos produtivos}

Códigos estabelecidos estão sempre na contingência de mudanças de situação, de qualquer ordem, que tensionam sua eficácia interacional. $\mathrm{O}$ encontro de códigos estabelecidos em situações diversas produz tensionamento mútuo. Em tais circunstâncias, setores diferenciados dentre os usuários dos processos estabelecidos podem ser levados a redirecionamentos inferenciais. Embora isso possa resultar em dificuldades de interação, pode também ser produtivo, levando a transformações, substituições e a outros âmbitos de interação, com novos códigos.

$\mathrm{Na}$ experiência TV/Comunidades, os códigos habituais de cada parte são pertinentes a suas respectivas lógicas interacionais. Não se trata, então, de modificá-los. O objetivo é o de encontrar e desenvolver códigos adicionais que viabilizem interações entre os dois processos. $\mathrm{O}$ trabalho - tentativo como é - pede inferências e invenções.

As experiências de pôr em cena jornalistas, em sua diversidade, não envolvem embate entre códigos já estabelecidos. Trata-se antes de um tensionamento de códigos canônicos da área por modificações internas a esses mesmos códigos.

Já no tensionamento dos fluxos jornalísticos, com a constatação da pressão pelas redes sociotécnicas, a dinâmica original vem de fora, levando a modificações nos códigos habituais a partir de inferências adaptativas. Além disso, em espaços externos ao do 
jornalismo profissional, são testados outros processos - iniciativas de informação acionadas fora do campo jornalístico, táticas de deriva a partir de movimentos sociais para divulgar suas próprias perspectivas - que podem vir a gerar novos códigos de informação para a sociedade.

Nas manifestações de 2013, as ações foram muito diversificadas, baseadas sobretudo em códigos gerais da cultura político-social da sociedade, abrangentes e flexíveis, servindo sobretudo como referência comum, mas sem imposição de adesões estritas. É claro que estavam presentes códigos de cultura geral, da língua em comum, práticas disseminadas de uso e produção de imagem, sem o que nada ocorreria. Havia ainda outros códigos compartilhados estes mais específicos - referentes aos gestos de reivindicação. Mas a prevalência do inferencial sobre códigos estritos, como processo aceito e valorizado entre os participantes, ofereceu espaço para a criatividade, para a improvisação e para o experimental.

Um aspecto interessante da consulta transformada é que, por um lado, códigos do campo psi demarcam o processo da coluna - determinadas características muito específicas da interação correspondem a temas e processos próprios do campo psicológico, psiquiátrico ou psicanalítico. Por outro lado, podemos considerar a coluna como um tensionamento, senão mesmo uma entorse, nos códigos mais canônicos da área. Assim, embora alguns códigos do campo especializado assegurem e direcionem as interações na ótica específica do campo, ao entrarem em tensionamento com códigos do senso comum (onde afinal se inscrevem os interagentes "clientes") podem sofrer estímulos redirecionadores. Eventualmente, em benefício mesmo do campo especializado - na medida em que se saiba apreender a possibilidade para desenvolver reflexivamente novas questões e processos. Os especialistas do campo de conhecimento podem assim se distribuir em uma dimensão entre a recusa 
de processos da midiatização e um esforço de ordem inferencial para rearticular códigos em tensionamento mútuo.

\section{Contextos}

Sabemos que um contexto não é simplesmente o "lugar de ocorrência" de um fato - mas sim um conjunto de relações complexas com o qual o fato se entretece, desenvolvendo uma situação que parcialmente decorre dessas relações e sobre elas age. É dentro dessa perspectiva abrangente que podemos afirmar que os dispositivos interacionais e os episódios de comunicação, correlatos a esses dispositivos, são modulados pelos contextos e incidem sobre eles.

A sociedade funciona dentro de setores e processos já constituídos, como contexto de inscrição inevitável para todos os episódios em que participantes entram em interação. Os contextos oferecem práticas e processos, tendências e objetivos, e posições estabelecidas que - qualquer que seja a originalidade dos objetivos específicos de uma interação - incidem sempre sobre o que aí se pretende desenvolver.

Por outro lado, é preciso pensar que esse "estado do contexto", para um episódio interacional qualquer, não é um quadro imutável e não existe desde sempre - foi construído a partir de contextos históricos anteriores ou por rompimentos. Essa construção se fez pela diversidade de interações então ocorrentes, das quais as mais pregnantes os modificaram em profundidade. Isso implica uma incidência potencial das interações sobre seus contextos, participando de sua composição. Conforme a relevância, a especificidade e a abrangência das interações, podendo incidir apenas sobre contextos mais imediatos, ou ainda sobre contextos ampliados.

Em nossas práticas reflexivas sobre a sociedade, temos estabelecido quadros classificatórios e de esquadrinhamento que 
fazem perceber o mundo segundo ângulos políticos, sociológicos, culturais, psicológicos, artísticos, educacionais, linguísticos, antropológicos, profissionais diversificados ou em visadas práticas gerais. Habituamo-nos, então, na academia, a perceber os contextos segundo um ou vários desses quadros. Na vida prática, conforme os âmbitos institucionais e profissionais das ocorrências.

Certamente cada um dos casos estudados pode ser enquadrado em um ou mais ambientes sociais conhecidos. Uma vez feito esse enquadramento, o caso passaria facilmente a ser explicado pelo contexto definido, assim como pelos conceitos e pelas práticas pertinentes ao contexto em que o caso tenha sido enquadrado. Podemos discutir as questões políticas, profissionais jornalísticas, educacionais, organizacionais, psicológicas, cinematográficas, ou outras, envolvidas.

Não se trata de descartar esses ângulos - de valor relevante para o comunicacional, pois é neles que se inscrevem os objetivos e muitos processos da atividade comunicacional aí em curso, assim como os códigos mais geralmente acionados. Não se trata, também, de pretender que o ângulo comunicacional seja per se o preponderante. Os conhecimentos relacionados àquelas diferentes áreas são relevantes para a elucidação dos mesmos objetos aqui observados, na perspectiva própria de cada uma dessas áreas.

$\mathrm{Na}$ presente obra, entretanto, trata-se de observar a variada dinâmica que reúne pessoas, grupos, sociedade, implicando uma processualidade comunicacional não exclusivamente determinada por nenhum daqueles ângulos (ainda que possa ocorrer segundo suas lógicas). Inversamente, o comunicacional forma um substrato transversal sem o qual nenhum desses objetivos, processos especificados ou enquadramentos se desenvolveria. Estes são vistos, então, como modalizações variadas do fenômeno comunicacional humano. 
Assumindo assim aquela premissa de que os dispositivos e episódios de comunicação são modulados pelo contexto, evidentemente não cabe separar conceitualmente a comunicação de seus contextos de ocorrência. Não cabe esquecer, nesses contextos, o que direciona a comunicação, nem o que a comunicação move. Mas o exame em perspectiva comunicacional deve facilitar a percepção de interfaces dentro daquele quadro classificatório em que tendemos a apreender e organizar aspectos, modos e perspectivas sobre a realidade que nos cerca. Sendo os processos comunicacionais e suas ocorrências diretamente participantes de todos os contextos sociais, tomar a comunicação como ponto de partida favorece uma compreensão mais aprofundada sobre outros ângulos em presença, postos em evidência pela incidência mútua entre os contextos e os dispositivos interacionais. A questão comunicacional é a de relacionar esses mundos diferentes, mas também a de compreender o que caracteriza, interacionalmente, cada um deles.

Os casos estudados se movem entre os seguintes tipos de contextos: político, jornalístico, educacional e psicológico.

\section{Contexto político}

O contexto político envolve tensionamentos estruturais no interior da sociedade, produzindo objetivos e táticas diversificadas no embate entre setores. Para o encaminhamento desses objetivos e sua negociação, comparecem as relações de poder entre participantes, argumentações em defesa dos objetivos e dos procedimentos de cada parte, busca do apoio de terceiros, ações em ou sobre circuitos voltados para a deliberação e para tomadas de posição.

Os processos mais sistematizados podem chegar a formulações normativas com peso jurídico, podem envolver trabalho cuidadoso de negociações, mas podem também se desenvolver em 
espaços de maior tensão e de golpes de força, por quem detém mais poderes; ou gestos de revolta e de desobediência civil, por quem só pode contar com sua causa e com a recusa da injustiça.

No embate entre a vigilância feita pelo Estado e a defesa social da esfera pública, aparece o espaço macropolítico dos modos de pensar a sociedade em foco abrangente. Como se trata de questão moldada em processos muito tradicionais, não se encontram padrões políticos sistematizados para regular a contradição entre as duas dinâmicas. Nesse contexto de comunicação apenas indireta, um lado maneja argumentos normativos e uma reiteração dos objetivos de segurança (e eventualmente a perseguição dos discordantes). $\mathrm{O}$ outro lado procura exercer um ativismo contestador, gerando circuitos nos quais a esfera pública possa ganhar acesso a informações relevantes para seu debate.

Ainda de ordem política é a experiência de junho de 2013. Assinalamos aí que o ângulo político é mais forte no processo interacional que na substância das reivindicações. Podemos tratar, no caso, de uma verdadeira política interacional. Enquanto no ângulo "reivindicação" se trata de um trabalho genérico de "medir forças" com os setores sobre os quais se faz a reivindicação, no processo interno trata-se de outro contexto político: o de obtenção de uma confluência entre objetivos diversificados. Certamente, a motivação reivindicatória é um direcionador relevante - mas a especificidade do processo foi antes decorrente da confluência interacional - que, por sua vez, incidiu fortemente sobre a processualidade política informada pela grande mídia - predominando sobre o desacordo desta.

É político também o contexto dos fluxos interacionais de redes sociotécnicas que tensionam a grande imprensa. $\mathrm{O}$ tensionamento e o âmbito político são outros, porém. Trata-se de informação e de âmbitos políticos não governamentais, dispersos em múltiplos setores de interesse da sociedade. Cada setor desenvolve suas próprias 
tentativas de circulação - em tensionamento ou alheando-se do ambiente da grande imprensa. Esta, por sua vez, ao ajustar processos, interage com algumas áreas e ignora outras. Nesse contexto, surgem condições para ações políticas em acionamento direto das redes; assim como para uma nova imprensa alternativa, mais aguerrida, favorecida agora pelas possibilidades tecnológicas digitais, e com um perfil de ação política mais agudo que o da grande imprensa.

O episódio de denúncia social, com o documentário Acercadacana, oferece outro ângulo de contexto político. Através de uma criação inscrita em modulações de ordem estética, nos processos de documentário cinematográfico, desenvolvem-se objetivos de ação política sobre a sociedade: pelo ângulo da denúncia (que mostra concretamente a opressão); e pelo ângulo mais difuso e abrangente de formação da opinião pública, que é (ao mesmo tempo) um estímulo de aprendizagem social das lógicas de cidadania. Enquanto na lógica da relação de forças a denúncia parece ter tido pouca incidência pragmática, no processo de formação e circulação de valores pode ter obtido incidência mais significativa.

\section{Contexto jornalístico informativo e de opinião}

Em alguns ângulos, o contexto jornalístico se articula com o contexto político, uma vez que este último depende da circulação de informações e dos processos de formação da opinião, frequentemente nucleados nos circuitos jornalísticos.

Por outro lado, também, há componentes desse contexto específico de circulação que caracterizam modos de funcionamento, questões profissionais, teorias da notícia, valores deontológicos, que definem os processos de apuração e seleção da notícia, e buscam assegurar a credibilidade dos jornais junto a seus públicos. 
Na questão da transparência contra a vigilância e o segredo, o campo jornalístico é ao mesmo tempo âmbito de processamento e setor tensionado (inclusive por iniciativas em paralelo ao jornalismo de grande empresa).

Uma negociação tradicional entre a grande imprensa e setores de governo faz o jornalismo estabelecido filtrar informações, ajudando a preservar aspectos que considera requeridos pela segurança. Mas correlatamente, essa leniência parece favorecer controles ilegais e ilegítimos pelo poder político, assim como usos em desvio de informações igualmente obtidas de modo irregular. Os circuitos informativos em defesa da esfera pública observados no capítulo sobre estes casos se desenvolve, então, ora em percursos paralelos, buscando um afastamento do contexto jornalístico, ora negociando, em diferentes tensionamentos com este.

Ainda no espaço jornalístico, mas sem notações de política geral, temos três âmbitos demarcados pela ênfase profissional: os ajustes operacionais feitos em processos jornalísticos para enfrentar a "concorrência" e as táticas de credibilidade específicas das redes sociotécnicas; as experiências em que o jornalista é posto em cena; e o circuito em Facebook que tematiza questões jornalísticas.

Nos ajustes operacionais do jornalismo, observamos um efetivo reajuste nos dispositivos interacionais da apuração e organização da notícia (em relação ao acionamento pelas fontes), para adaptação do contexto profissional às modificações no contexto social de circulação de informações e opiniões.

Nos quatro casos de noticiadores noticiados, o contexto diretamente profissional modaliza centralmente os processos; e as experiências processuais observadas vão construindo determinados padrões menos ou mais interessantes no desenho complexo desse contexto composto pelas lógicas da profissão - ou seja, vão redirecionando essas mesmas lógicas. Algumas das experiências 
podem gerar padrões de estabilidade - incidindo assim mais diretamente sobre o contexto profissional

No dispositivo Márcia Franz, em que se articulam o interesse dos participantes sobre a atualidade e sua observação refletida a respeito dos processos jornalísticos de referência e elaboração dessa atualidade, há relacionamentos próximos entre a perspectiva profissional e a perspectiva acadêmica. Paralelamente, uma participação em lógica de amadores oferece o senso comum como contexto geral para o estar junto e para a reflexão ponderadora.

\section{Contexto Educacional}

Ultrapassamos aqui as perspectivas de campo escolar e universitário, em que a educação aparece em modo organizacional e com objetivos planejados e explícitos. Compreendemos, na expressão, os espaços mais vastos da aprendizagem - do mundo da vida, das práticas profissionais, das leituras independentes e da permeação em qualquer processo social que complemente a experiência e a competência reflexiva do participante.

Com essa perspectiva ampliada, é fácil perceber que a "interface educacional" pode ser percebida como contexto modulador em uma grande variedade de dispositivos interacionais, mesmo quando estes são relacionados prioritariamente a outro contexto, como o entretenimento. $\mathrm{E}$ ainda, que os processos comunicacionais mais variados podem incidir sobre a aprendizagem pública compondo a formação do cidadão. Embora a sociedade tenha especializado um campo para as atividades educacionais, a formação de seus participantes é diretamente relevante em muitos outros contextos.

As relações de interface da comunicação com o contexto educacional abrangente (pelo ângulo das aprendizagens públicas) 
comparecem em três casos: conversações no Facebook, minissérie histórica e interações de TV educativa com grupos comunitários.

Nas minisséries históricas, a narrativa de entretenimento, com características de estimulação estética é contextualizada em um ambiente reconhecido pelos espectadores como "histórico". A referência, em deslocamento com relação aos dias atuais, acaba compondo um processo difuso com possibilidades abrangentes sobre a formação do senso comum e da cultura em geral.

No perfil do Facebook, a incidência mais imediata da conversação é sobre os processos formadores - não só universitários, mas, dada a participação de profissionais e de amadores, com possibilidades mais abrangentes de formação e de experiência prática. A expansão do dispositivo acadêmico habitual de orientação amplia a abrangência e diversifica as lógicas da conversação em aprendizagem mútua.

O outro caso, mais formalmente educativo, é a experiência de articulações entre televisão educativa e grupos comunitários. A busca de processos interacionais - na medida de seus encaminhamentos - pode favorecer o desenvolvimento de circuitos em que requerimentos de formação de competências e as estratégias de produção de materiais passam a se articular com reforçada qualidade e pertinência.

\section{Contexto psicológico}

Finalmente, temos um caso em que os episódios se desenvolvem na fronteira entre o âmbito social da midiatização e um contexto fortemente especializado - o campo social dos conhecimentos teóricos e de exercício clínico das áreas psicológicas. As relações entre setores especializados e o ambiente social geral são tipicamente desenvolvidas segundo as lógicas específicas do campo. No caso 
estudado, observamos um tensionamento que faz a experiência ter uma incidência sobre o contexto.

O contexto psicológico fornece processos profissionais e científicos modalizadores das interações que se passam em seu ambiente de referência. Ao mesmo tempo, o dispositivo estudado exerce uma ação tensionadora sobre o campo especializado (assim como o fazem outros dispositivos, em experiências de midiatização, nessa área). Esse tensionamento não se resolve, é claro, no embate aberto, na contestação - embora possa apresentar episódios de recusa ou de normatização, para controlar as experiências: os campos sociais especializados tendem a resistir a atravessamentos de suas lógicas interacionais estabelecidas.

Mesmo com a resistência do campo especializado, processos experimentais se desenvolvem e são testados - alguns dos quais podem acabar prevalecendo, sendo absorvidos pelo campo especializado; outros podem realimentar diretamente, nas fronteiras do campo estabelecido, qualificações de conhecimento social e estimulações nos processos de senso comum. O caso é particularmente ilustrativo da incidência mútua entre contextos e dispositivos.

\section{Circulação \& Circuitos}

A busca por objetivar as diferenças - para fazê-las agir, para obter composições, para superar os desajustes ou para compreender - leva à geração de processos materiais para fixar a expressão dessa objetivação. Os modos práticos do enfrentamento das diferenças podem assim ser registrados, permitindo lembrar e aperfeiçoar o que tentativamente deu certo. As tentativas feitas e as regras interacionais que assinalam as lógicas criadas se desdobram, então, em sua expressão material, que podemos chamar, simplificadamente, de "produtos da interação humana". 
A fixação do processo em modo material amplia a possibilidade de proteger e propagar os modos pelos quais aquele material se tornou possível. Por outro lado, cria a possibilidade de que aquele produto se desloque para outros e outros contextos imediatos, que não só o recebem, como agem sobre ele modificando sentidos. $\mathrm{O}$ produto que circula é memória materializada que transporta seus significados; mas é também matéria flexível para trabalho interacional subsequente.

Na medida em que essa circulação resulta em reiteração, forma circuitos. Mais importante que os meios de comunicação (com suas lógicas e "gramáticas" específicas) são os circuitos sociais que articulam o fluxo comunicacional segundo suas próprias lógicas.

A reiteração de uso de circuitos viabiliza "escuta" do que pode suceder adiante, permitindo uma "retroação de sentidos" e ajustes do que vai circular. É nesse sentido que podemos dizer que o circuito é "produtor de sentidos" - o circuito "elabora" o produto que circula.

Por isso, ao observar os circuitos, produtos e processos de circulação, devemos evitar uma ênfase no produto como o objeto plenamente definido que circula - como se esse movimento do produto é que caracterizasse o circuito, à exclusão de outros processos. É importante perceber que "circuitos" e "produtos" se definem e se elaboram mutuamente. $\mathrm{Na}$ análise, mesmo quando as circunstâncias específicas solicitam mais atenção para uma das duas dinâmicas, a do produto e a do circuito, ambas estão em ação.

O enfoque conjunto sobre circuitos e sua relação com os produtos ajuda a superar a perspectiva (frequentemente criticada, mas ainda acionada) de pensar comunicação como passagem de informação de um emissor a um receptor. $\mathrm{Na}$ lógica dos circuitos, com seus fluxos reiterados e sua potencialidade de retroação de 
sentidos, quem recebe o produto é igualmente produtor comunicacional, pelos processos mesmo de recebimento e uso. As ações transformadoras sobre o próprio produto e as ações interpretativas na continuidade do fluxo são mais propriamente comunicacionais do que aquela categorização fechada permite perceber.

É fundamental, portanto distinguir os dois conceitos - comunicação e informação - o que nem sempre é simples porque a informação é um componente provável dos processos comunicacionais - sendo preciso, porém, não hipostasiar a passagem nem pretender uma identidade entre os pontos de partida e de chegada. Na comunicação, o sentido é central - e não se trata apenas do sentido implicado na informação, mas sobretudo os sentidos produzidos sobre a informação (assim como os sentidos que produzem a informação). Assumindo nossa perspectiva de dispositivos interacionais constituídos por códigos e processos inferenciais, a informação é "código" - mas não apenas código criptográfico ou de transposição: é material sempre interpretável. Contém sentidos, certamente, mas estes são ao mesmo tempo fixados e frágeis: a comunicação implica também a inferência que os revê, ajusta, transforma. São os circuitos que realizam essa ação.

Todos os casos empíricos estudados neste livro evidenciam essa relação de incidência mútua entre circuitos e produtos, em processos e intensidades variáveis.

\section{Outros circuitos para um mesmo produto}

Um produto feito originalmente para um circuito pode ser apropriado em outro - em que se fará ressaltar algumas características mais que outras, aí exercendo suas interações, que fazem então aquele produto seguir adiante, agora com outras perspectivas, reflexões e interpretações agregadas. 
O produto "informação" é transferido do circuito de espionagem e segredo para o circuito notícia. Enquanto mantido secreto no seu processo de geração, o produto tem modos de obtenção, seleção e uso determinados por seus objetivos de vigilância, associados a pretensões de segurança ou de tortuosidade política. A possibilidade de fazer essa informação circular em outros espaços de maior abrangência, em favor da esfera pública, modifica a informação, atribuindo outros sentidos e portanto modificando diretamente o produto. Impede assim processos que só "fazem sentido" com a manutenção do segredo.

A lógica de entretenimento da minissérie estudada permite, dadas suas qualidades intrínsecas, uma circulação em outra processualidade - os circuitos da aprendizagem. A angulação específica ocorre com base no trabalho interpretativo que faz ressaltar essa potencialidade. O programa Faixa Comentada corrobora esse ângulo interpretativo. Agindo interacionalmente sobre a minissérie, redireciona o produto para outro circuito, exercendo ação voltada para estimular aprendizagem através de procedimentos práticos: falar sobre, fornecer informações, ouvir diferentes vozes, estimular o entendimento e a reflexão.

\section{Sintonias entre produto e circuitos}

Alguns produtos, no momento mesmo de sua feitura, recebem direcionamentos, solicitações e expectativas dos circuitos a que se destinam. $O$ dispositivo interacional que gera uma produção é a matriz que desde o início busca sua articulação com os circuitos de referência - aqueles para os quais foi realizado.

O dispositivo objetivado no documentário Acercadacana é o ponto nodal de pelo menos três circuitos. Um, cinematográfico, em que circulam filmes sobre questões sociais e envolvem apreciadores 
competentes do processo, que relacionam as questões tratadas e o modo de tratá-lo. Outro envolve a difusão entre participantes sociais diversos - ambiente no qual, além das interpretações sobre o processo, sua denúncia apresenta um potencial de esclarecimento, de formação crítica da opinião, de estímulo a posições contra a injustiça.

Percebemos ainda um terceiro circuito, jurídico-político, para o qual o documentário volta sua denúncia como peça de acusação que deveria ser levada em conta. No imediato, sabemos que essa interação específica, relevante como é, provavelmente não se desenvolve. É preciso imaginar que o segundo circuito, em que o documentário se apresenta como formador, o documentário específico se soma a outros e outros episódios e produtos de sentido similar. Esse modo interacional difuso e disperso pode ter, no longo prazo, um valor civilizatório, em que a comunicação manifesta seu potencial transformador.

\section{Um circuito imaginado pede um produto}

A percepção de potencialidade de um circuito imaginado pode levar a tentativas de sua efetivação. A invenção do circuito pode caracterizar a busca de um âmbito estabilizado para que um tipo de produtos possa ser desenvolvido e reiterado com eficiência. O esforço de desenvolvimento do circuito - que relacionará participantes sociais - implica também a necessidade de formatar um produto adequado para a qualidade dessa circulação.

$\mathrm{O}$ desenvolvimento de um dispositivo articulador entre TV e grupos comunitários, viabilizando a interação, se volta para a possibilidade de um circuito interacional que faça circular produtos televisuais de uma emissora no âmbito comunitário; e, em direção à emissora, perspectivas, requerimentos e expectativas das 
comunidades como informação qualificadora e especificadora de tipos de produtos pertinentes.

Os produtos diversificados e habituais da emissora já apresentam, evidentemente, algum interesse para os grupos comunitários, mas o desenvolvimento de dispositivo interacional e de circuitos específicos age diretamente sobre a caracterização dessa produção. A produção das maletas evidencia justamente essa necessidade de correlação entre circuito e produto em desenvolvimento.

\section{Circuitos são redesenhados}

Quando a sociedade dispõe de circuitos longamente estabelecidos, os produtos são feitos já na previsão dos circuitos que lhes oferecem recebimento, acolhida, interpretações e críticas (e ainda os redirecionam, eventualmente, para outros circuitos). Com todas as variações inerentes aos produtos singulares, o processo geral de produção e circulação aciona esses padrões gerais.

Entretanto, essa realidade pode sempre sofrer redirecionamentos, em função de incidências diversas - levando à necessidade (ou ao interesse) de reformulações processuais nos circuitos e nos produtos. Assim como no século XX a entrada em cena do rádio e da TV incidiram sobre a circulação jornalística, hoje, as redes sociotécnicas têm gerado outros circuitos e diferentes tipos de produção de notícias que tensionam o jornalismo.

No dispositivo Márcia Franz, as fronteiras se expandem para além do espaço universitário, fazendo interagir dispositivos existentes fora das redes, tanto quanto fluxos interacionais em rede.

Os circuitos noticiosos, ao colocar em cena o jornalista, o fazem modificando o tipo de produtos - seja em atendimento a circuitos externos; seja por iniciativa de acionar processos colaborativos de rede; seja ainda pela percepção da potencialidade de um 
circuito de espectadores interessados na apreensão de processos jornalísticos de apuração e edição de notícias.

$\mathrm{O}$ estudo sobre o tensionamento que redes sociotécnicas produziram sobre a produção jornalística não traz a discussão de produtos específicos - mas mostra dois tipos de ação de circuito sobre o processo produtivo. O primeiro é um tensionamento direto em redes sociotécnicas, o que leva a ajustes das empresas jornalísticas para buscar insumos e processualidade característicos das redes. A outra ação é o desenvolvimento, lento e diversificado, de circuitos externos ao jornalismo canônico, com objetivos de produzir e de fazer circular informações noticiosas e opiniões a partir de outras lógicas interacionais, com outras metas, e sobre questões sociais que não encontram acolhida adequada ou suficiente no processo jornal.

Alguns circuitos estabelecidos permitem acolher outros tipos de produtos, inicialmente não previstos para esse modo de circulação. $\mathrm{O}$ jornalismo vem experimentando, através de sua história, essa possibilidade de inserção de outros tipos, formatos e objetivos de produtos, além da notícia propriamente dita - no circuito-jornal, e mais recentemente, nos circuitos rádio e TV. No mesmo sentido, redes sociotécnicas - inicialmente experimentadas na constituição dos primeiros circuitos para os quais foram dirigidas - a cada dia são testadas para outros e outros produtos e processos.

A especificidade da coluna Vida Íntima, no que se refere à questão de circuitos, é o fato de uma interação tradicionalmente realizada no espaço protegido da consulta clínica ser posta em circuito jornalístico. Junto com as demais modificações ocorrentes, a circulação da demanda e da resposta de elucidação caracterizam o produto e o próprio sentido da coluna, tensionando e modificando o processo interacional habitualmente relacionado ao dispositivo consulta. 
Naturalmente surge aí outro ângulo de circulação. $\mathrm{O}$ circuito experimental da coluna, atravessando o campo psicológico, produz uma tensão anticanônica, que pode ser interacionalmente trabalhada tanto em recusa como em dinâmica para repensar questões da área e modos especializados para seu encaminhamento clínico - o que implicaria um potencial redesenho nos circuitos próprios do campo.

\section{Circuitos que produzem}

Em determinados circuitos, a confluência de percepções diversas resulta em um processo de produção conjunta - que talvez seja uma das possibilidades mais marcantes no processo comunicacional da circulação.

Nessa situação, mais do que perceber um produto claramente destacado que circula, o que se percebe com mais evidência é um processo interacional em dimensão e diversidade de circuito que, como emanação de sua atividade comunicacional, gera produtos.

O dispositivo Márcia Franz se caracteriza ao mesmo tempo como um circuito pelo qual fluem proposições, perspectivas a respeito de seus temas de interesse, reflexões, interpretações, críticas - formadoras de opinião e aprendizagem. Tem assim uma proximidade com as lógicas da conversação esclarecida. Seu produto é a própria conversa; e a circulação de falas diversas é que gera esse produto.

Nas manifestações de junho 2013, os circuitos de reivindicação social se caracterizam diretamente como a dinâmica produtora. Os "produtos" são as múltiplas expressões da manifestação, os memes que viralizam na internet, a ação pública das passeatas transmitidas como notícia, a grande quantidade de imagens fotográficas e vídeos, os cartazes. 
Essa produção, espalhada desde múltiplas origens pontuais, compõe um processo colaborativo peculiar, justamente pelos aspectos não previamente concertados, mas que evidenciam sua dinâmica produtiva.

\section{Sistema de relações - 0 eixo experimental dos dispositivos interacionais}

As lógicas específicas de um episódio comunicacional, de um dispositivo ou de um circuito são dadas pelo sistema de relações que se estabelecem, não só entre os participantes, mas entre todos os elementos pertinentes - objetivos, incidências do contexto e das interações sobre este, códigos e modos inferenciais acionados, tipos de produto em pauta, processos de cooperação e de tensionamento mútuo, sentido específico das diferenças em presença e como estas são direcionadas.

Essas características foram consideradas nos itens anteriores, através de reflexão assim como de referências aos casos empíricos estudados. Resta, entretanto, um ângulo, particularmente central para a compreensão dos sistemas de relações, porque diz respeito ao que é comunicacionalmente tentado nos processos interacionais. $\mathrm{O}$ ângulo tentativo é que dá direção aos dispositivos e circuitos, assim como aos episódios relacionados a estes.

$\mathrm{O}$ que devemos assinalar aqui é uma presença de modelos estabelecidos na sociedade, cujos padrões são referência generalizada, ladeados, porém, por processos tentativos que os modificam, tensionam ou buscam substituir. Encontramos ainda situações fortemente experimentais, em verdadeiro esforço de invenção social que se faz sobre um fundo estabelecido.

Para o trabalho de compreensão, ou na pesquisa comunicacional, é preciso ir além dos processos canônicos gerais, para perceber 
potencialidades em ação nos episódios que venham a ser investigados. Em graus variáveis de probabilidade, a busca de realização qualitativa da comunicação humana ultrapassa códigos, dispositivos e circuitos disponíveis, exigindo invenção e inferência e, portanto, algum processamento experimental.

Em algumas situações, mesmo que vários ângulos e processos de dispositivos interacionais bem estabelecidos sejam ofertados pela sociedade, pela cultura e pelo ambiente institucional - e sejam pelo menos em parte acolhidos - muitas vezes não se encontra, pronta, uma processualidade padrão suficientemente adequada a uma situação singular, sobre a qual bastassem inferências de ajuste à situação concreta. Os objetivos dos participantes não encontram regras adequadas para que a interação progrida. Estas precisam ser geradas a partir das circunstâncias, agora a serem puxadas em direção ao que se pode pretender. São as táticas e estratégias, então, que podem desenvolver outros códigos.

Quando, inversamente, os participantes de episódios interacionais assumem um dispositivo como natural para dada situação, agindo "dentro" dele, ainda assim a conjuntura própria do episódio, e a singularidade dos objetivos de cada participante redirecionam os objetivos padronizados do dispositivo. Mesmo no exercício de dispositivo habitual, os episódios solapam e acrescentam, transformando os dispositivos.

Isso significa que os episódios interacionais acionam práticas anteriormente desenvolvidas e conhecidas que servem de referência como dispositivos para sua interação. Mas, ao mesmo tempo, os episódios de interação remodelam os dispositivos - seja por experimentação e invenção; seja pelo simples uso.

Entre as duas posições que delimitam a dimensão (ausência de dispositivos e circuitos; e dispositivos e circuitos corriqueiramente acionados), diferentes composições de acionamento 
e de experimentação podem ocorrer. Vamos observar as posições relativas dos nove casos, organizando-os em três conjuntos: os mais próximos do primeiro extremo da dimensão (experiências \& invenção); no outro extremo (exercitação de dispositivos estabelecidos); e graus variados de experimentação e uso, em pontos intermediários (deslocamentos \& expansão). Com isso, se evidenciam as transformações que ocorrem ou são tentadas em cada uma das situações.

\title{
Experiências \& Invenção
}

A diversidade de "mundos" em conexão que compõem a complexidade da sociedade contemporânea põe com premência a questão comunicacional. Esta é assumida por Adriano Duarte Rodrigues como a dificuldade de articulação entre "mundos diversos" em uma mesma sociedade. Com a modernidade, a experiência tornou-se

\begin{abstract}
cindida numa multiplicidade de campos, sendo cada um regido por normas próprias e instaurador da sua própria ordem simbólica. É este o quadro em que surge a dificuldade de compatibilizar entre si exigências legítimas diferentes e, por vezes, contraditórias (Rodrigues 2011, 92).
\end{abstract}

Os campos enfatizam seus modos de relacionamento interno e com o ambiente; e a sociedade desenvolve e estabiliza circuitos articuladores do conjunto. Mas eventualmente, as circunstâncias históricas exigem relacionamentos outros, com diferentes direcionamentos ou especificidades entre os próprios campos e entre estes e seu ambiente. Ou então, em seu próprio interesse, surgem necessidades de redirecionamento. E ainda, os campos são atravessados por circuitos, em tensionamento, contestação ou conjunção. Em tais situações, os participantes sociais não encontram, fora os padrões 
culturais mais genéricos da interação humana, dispositivos interacionais disponíveis para a comunicação requerida. É preciso inventar, por experimentação social, estratégias e táticas articuladoras.

No conjunto dos casos empíricos, os pesquisadores observaram três dessas experimentações: para a busca de transparência de informações; para articulações entre TV e comunidades; e nas experiências de informação noticiosa, particularmente em deriva.

O objetivo de criticar e de fazer circular determinadas informações contidas em círculos da vigilância e do segredo encontra limites nos processos canônicos do jornalismo. Assumida a insuficiência desse processo, setores interessados na defesa da esfera pública passam a experimentar possibilidades por outros dispositivos e circuitos. Instala-se aí um processo de invenção social, de que o estudo empírico mostra tentativas marcantes, com graus variados de inovação.

Com Assange, a tentativa é a de criar um macrocircuito informativo em paralelo ao sistema informativo padrão, do jornalismo. A experiência de Snowden é mais pontual - seja porque irrepetível em sua singularidade, seja porque prefere acionar setores do jornalismo estabelecido - reforçando seus dispositivos mais críticos e ativos. Greenwald, com o The Intercept, leva adiante esse desafio com uma experiência interacional em padrões mais imediatamente viáveis - parcialmente de tipo jornalístico, com seus processos e critérios, parcialmente em dispositivo de ativismo.

A lógica dessas tentativas e do processo social que as move é ocupar uma lacuna interacional e política entre dois âmbitos ao mesmo tempo instituídos e contraditórios entre si - o que exige invenção social de dispositivos e de circuitos com vocação para gerar regularidade de processos.

A experiência do dispositivo em construção "TV/comunidades" resulta de um objetivo de relacionamento que imediatamente faz perceber a lacuna de procedimentos interacionais pertinentes. 
Não há práticas estabelecidas que organizem um sistema de relações entre os dois lados: não há dispositivos estabilizados para relações continuadas - os dois setores "não falam a mesma língua". Os processos cooperativos, ainda que com eventuais tensionamentos, pedem a criação de uma mesma "linguagem" entre interagentes. A composição de atividades em comum depende de um dispositivo interacional intérprete com a missão de apreender as lógicas interacionais dos dois setores e se constituir como elemento "de tradução" nas duas direções. Isso corresponde à própria lógica de constituição de regras - inicialmente não existentes - a partir das estratégias de aproximação que vão sendo tentadas.

$\mathrm{O}$ estudo dos fluxos comunicacionais mostra uma potencialidade da deriva: esta favoreceria a invenção de circuitos informativos e de opinião indiferentes ao jornalismo canônico, gerando processos próprios no interesse de setores sociais de menor acesso, para suas perspectivas e reivindicações.

Não é, portanto, surpreendente que outros e outros processos de voz e de interação se experimentem, aproveitando, hoje, funcionalidades tecnológicas tornadas disponíveis (e sobretudo redirecionadas por ação social para tais usos e tentativas). Seja para modificar "por dentro" o campo jornalístico; seja para tensioná-lo a partir de fora; seja ainda para inventar outros e diversificados circuitos. $\mathrm{O}$ estudo mostra toda uma variedade de lógicas e processos de produção e circulação de informação.

\section{Deslocamentos \& Expansão}

Muito frequentemente, o processo transformador não exige a invenção de dispositivos ou circuitos ad-hoc, a partir de uma lacuna. Processos disponíveis na cultura podem ser deslocados de seus espaços de prática mais habitual, sob tensionamentos diversos. A expansão ou deslocamento, no acionamento de dispositivos 
interacionais estabelecidos, corresponde a seu uso em situações mais ou menos diversas às de suas práticas mais habituais; ou ainda, como ponto nodal relacionado a outros circuitos.

Um desses deslocamentos, na contemporaneidade, tem sido resultado da entrada em cena de meios modernos de comunicação - cinema, rádio, TV e, mais recentemente, os processos informatizados e as redes sociotécnicas. Na medida da diversificação e da abrangência de tais possibilidades técnicas, os diversos âmbitos sociais passam a fazer experimentações a partir de seus dispositivos e circuitos habituais, transformando-os.

$\mathrm{O}$ que chamamos de midiatização, como tendência generalizada do ambiente social, não corresponde à simples presença crescente daqueles recursos técnicos; mas sim ao fato de que a sociedade, em todos os seus âmbitos, busca ampliar e/ou qualificar seus processos interacionais fazendo incidir seus objetivos (de variada natureza) em acionamentos midiáticos tentativos. Mais que a presença da mídia, a midiatização é essa profusão experimental de uso de recursos tecnológicos, gerando outras lógicas para esse acionamento. Por um lado, as tecnologias deslocam ou permitem expandir processos habituais; por outro lado, são os objetivos sociais que "desviam" usos inicialmente previstos das tecnologias.

$\mathrm{O}$ atravessamento de campos sociais por circuitos diversos exige, às vezes, a invenção de novos dispositivos, como vimos antes. Mas também parecem ocorrer processos de ajuste e adaptação em dispositivos habituais. $\mathrm{O}$ desenvolvimento do senso comum, que valoriza conhecimentos especializados a partir de pragmáticas locais e singulares, favorece uma busca acelerada de respostas fora dos padrões dos campos sociais - o que pode gerar expansões e deslocamentos.

Vamos observar as possibilidades de deslocamento e expansão encontradas pelos pesquisadores dos casos empíricos. 
Nos movimentos de junho 2013, há certamente um dispositivo - a passeata - que aparece como referência estabelecida. Entretanto, mantido o aspecto comportamental mais imediato desta (povo reunido nas ruas, expondo suas reivindicações aos passantes e à captação das mídias), as demais características do sistema interacional são fortemente deslocadas pela transformação de componentes e processos. A concentração de proposições, em palavras de ordem sistematizadas, desaparece, abdicando-se ainda do planejamento que busca explicitar aos interlocutores os focos principais e as motivações do movimento.

Os episódios transformam então o dispositivo em processo colaborativo, disperso, euforizante. Certamente essa dinâmica entre os participantes se transmite aos interlocutores externos - a tal ponto que, mesmo recebendo indicações a distância, via grande mídia, muitos se sentiram concernidos e participantes - o que dinamizou ainda a parte presencial e a parte em rede por outras e outras adesões.

Encontramos referências históricas para tais expressões - euforizantes por seu ângulo comunicacional - de vozes que finalmente conseguem ir a público. Não pensamos apenas em processos recentes (que às vezes são atribuídos tão somente à existência de redes sociotécnicas). Muito antes de tais funcionalidades, o maio de 68 na Europa conteve elementos desta lógica comunicacional, de sintonia expressiva que favorece o congraçamento de reivindicações.

Sobre os processos da interação clínica psi, em que demandas e sofrimentos são refletidos com base em conhecimentos clínicos e teóricos de área especializada, o dispositivo da coluna Vida Íntima desenvolve algumas características destacadas: a descontinuidade da interlocução; a iniciativa do consulente, que expõe a demanda 
em seus próprios termos, fora do ambiente protetor; falas esclarecedoras do responsável pela coluna, que aceitam o terreno de senso comum em que as falas são postas, para aí produzir sua resposta; e - particularmente - o olhar de um terceiro se coloca como participante direto da interação. Não somente porque se dá como "público", como receptor; mas também porque o conhecimento de sua presença inevitavelmente incide sobre as duas falas mais expressas, a dos consulentes e a do terapeuta. $\mathrm{O}$ dispositivo se coloca assim como espaço aberto para o exercício da "extimidade".

O atravessamento é ativado por participante do campo especializado, com sua formação, acervo de conhecimentos e práticas processuais. A tentativa, porém, o expõe em posição marginal ao campo, pelo acolhimento e experimentação de interações que são e não são definidas pelas lógicas interacionais ali estabelecidas.

As experiências que atravessam difusamente o campo jornalístico são ações da sociedade. Trata-se de tensionamentos, de atravessamentos e de substituição dos padrões jornalísticos estabelecidos para circulação da informação na sociedade. Isso ocorre a partir de diversos "lugares", externos ao jornal e de algum modo relacionados mais de perto à própria situação informada. As lógicas de apuração, de formulação, de credibilidade se diversificam. Correlatamente, os processos de seleção, preparação e circulação da informação são experimentalmente outros.

A empresa jornalística se ajusta para enfrentar o tensionamento - absorvendo e domando táticas e processos. O que implica, no âmbito interno ao campo jornalístico, toda uma série de questões interacionais relativas a seu modus operandi, diversificando suas relações com as fontes, fazendo rever o próprio sentido dessa figura, modificando, ainda, suas relações com o público leitor/receptor.

No desenvolvimento dos processos de busca de transparência contra o circuito do segredo e da vigilância, uma parte das atividades 
envolve também, além da invenção de dispositivos, processos de deslocamento. Trata-se, sobretudo no caso Greenwald, da tentativa de articulação de processos de ativismo social com padrões do jornalismo, na experiência do The Intercept.

$\mathrm{O}$ jornalismo posto em cena é resultado de diferentes circunstâncias: o fato de a TV mostrar a pessoa que fala e informa; um interesse social difuso sobre a vida de pessoas em cena; funcionalidades das redes sociotécnicas que, ao comentar, propagam; o interesse empresarial na busca de audiência; uma tomada de consciência generalizada sobre os processos da mídia. Não se trata de um mesmo dispositivo acionado em quatro episódios, mas de um mesmo tipo de processo que se manifesta e é testado em diferentes dispositivos em elaboração.

Temos aqui, ainda, um processo de deslocamento de dispositivos habituais. Uma diferença, com relação a ajustes promovidos a partir de tensionamentos externos, é que os deslocamentos parecem corresponder a iniciativas do próprio espaço profissional da TV empresarial - seja em sua busca de audiência, seja para tentar sintonizar outros modos de credibilidade junto aos espectadores.

O "dispositivo Márcia Franz" parece se caracterizar por uma expansão do ambiente acadêmico. Os diálogos acadêmico-profissionais caracterizam uma derivação de práticas habituais em modo presencial: relações de orientação acadêmica, interação de colegas de mesma área de trabalho, estudos acadêmicos sobre o processo noticioso, debates profissionais de jornalismo, conversas de amadores sobre a atualidade em torno.

A experiência, mesmo, é a reunião desses vários ângulos em um só dispositivo - no qual ressalta uma posição de "liderança de opinião" viabilizada pela experiência da responsável pelo perfil na rede, fazendo ultrapassar os espaços mais canonicamente "de campo" (acadêmico ou profissional jornalístico) - propositalmente 
trazendo as reflexões mais sérias para um âmbito propriamente dialogal e inscrito no processo conversacional.

A expansão percebida pelo estudo de caso da minissérie corresponde à possibilidade de entrada de produto interacional em outro circuito, diverso daquele para o qual foi produzido e do qual o processo é ponto nodal - como narrativa de entretenimento e fruição estética.

Ao fazer entrevistas e interpretações sobre a minissérie, o programa Faixa Comentada estimula a circulação nessa outra perspectiva, transforma o produto inicial, ao produzir uma outra estrutura significativa de articulação. No circuito cultural educativo do programa, os espectadores são expressamente estimulados pelo processo dialogal e interpretativo como procedimento de aprendizagem.

Naturalmente, em todas as situações observadas, ao ser expandido para outras situações interacionais, o dispositivo se modifica, em maior ou menor grau - podendo se tornar apenas uma variante do já estabelecido, ou desenvolver procedimentos mais específicos.

Certamente uma grande parte dos dispositivos interacionais foi se desenvolvendo por processos de expansão (ou deslizamento) de uma situação para outra, com algum modo de ajustes inferenciais, na transferência.

\section{Exercitação de dispositivo interacional acionado}

Nas práticas estabelecidas em ambiente cultural, dispomos de uma grande variedade de dispositivos de interação que basta acionar, em função de uma situação, de um objetivo social, de processos reiterados de ordem profissional ou da vida cotidiana. Tais dispositivos, habituais entre os participantes, são "naturalmente" associados às rotinas, às situações conhecidas e seus objetivos. 
Ainda assim, esse simples exercício constante de práticas incorporadas pede algum ajuste inferencial às singularidades da situação ou dos participantes. Fora de um mundo excessivamente arraigado em tradições, mesmo nas reiterações os ajustes e as táticas diferenciadas se demarcam como procedimento tentativo.

Em algumas áreas da atividade humana, a repetição do mesmo tende a sulcar o gesto incorporado que afasta qualquer "desvio" inovador. $\mathrm{O}$ exercício de atividades burocráticas parece tender a uma maximização da gestualidade interacional mecânica. Não por acaso, quando, em um contexto social qualquer, se percebe uma recusa de ajuste inferencial à realidade singular dos fatos, o olhar crítico faz referência à metáfora da burocracia.

Em outras áreas de exercício de dispositivos oferecidos pela cultura, podemos ter um processo de criação. Quando a criatividade é a tônica, mesmo dentro de dispositivos estabelecidos (que caracterizam as interações relacionadas a tipos de produto, a gêneros, a processos estabilizados de fruição estética), a expectativa é de que cada produto singular a ser posto em circulação traga ao menos alguns aspectos de originalidade. Ainda que se conte (particularmente na sociedade em midiatização) com elementos pré-compartilhados com os interlocutores - por estruturas reconhecidas, por padrões de serialidade - espera-se sempre uma margem de oferta para a descoberta, para a surpresa da fruição, para a contribuição inferencial.

No conjunto de casos estudados, foram destacadas duas experiências nesse sentido. Embora os materiais produzidos se inscrevam em dispositivos de reconhecimento habitual - o documentário cinematográfico e a minissérie de referência histórica - os dois episódios estudados trazem a tática e a tentativa voltadas para a construção de singularidade e da incidência ativa no contexto. Ao 
mesmo tempo, em termos de fruição estética e de apreensão de sua substância motivadora.

O filme Acercadacana se caracteriza como episódio de um dispositivo habitual: documentários de denúncia social - o que já cria um direcionamento específico, dentro do dispositivo geral "documentário". Comporta ao mesmo tempo uma singularidade interacional que o assinala como interessante experimentação, pelas iniciativas da protagonista em cena.

É justamente o sucesso dessa sincronia que elucida e ilustra uma questão centralmente comunicacional. Contra as posições que privilegiam a dinâmica individual e as que só enxergam as determinações impostas "pelo social", o que vemos no documentário é uma produção mútua, a partir da convergência entre contexto e ações individuais em vista de objetivos comuns. A voz ativa da personagem em cena, no que se refere ao direcionamento de sua própria ação, da câmera e do andamento do filme, reproduz e reforça seu objetivo de circulação, dirigido à situação jurídico-política polemizada. A denúncia se vincula a essa situação por um processo interacional mais concreto que uma simples argumentação discursiva sobre a injustiça em curso, e se manifesta em ação concreta e simbólica.

Na minissérie histórica observada, o esforço criativo, a elaboração narrativa, a construção de personagens, meio ficção, meio referência histórica, resultam em um material que, entrando em circulação - seja no circuito do entretenimento e da fruição estética, seja por sua expansão para o circuito de estímulo a aprendizagem, aparece mais pela singularidade que pela simples referência ao dispositivo.

Os episódios da criatividade tendem a acionar mais os processos inferenciais que os códigos dos dispositivos acionados. $\mathrm{O}$ próprio fato de que, na circulação social, damos sempre espaço 
relevante para o não padronizado, para o que pede inferência e descoberta, sublinha e evidencia a estrutura básica da comunicação como um jogo entre o codificado e o que não cabe nos códigos - $\mathrm{e}$ por isso mesmo, surpreende e modifica.

\section{Conclusão}

$O$ fato de enfatizarmos o potencial transformador da comunicação não deve ser confundido com uma visão ingênua de que seus processos levem necessariamente a aperfeiçoamento constante da sociedade. É importante sublinhar que a comunicação não aparece apenas nos resultados humanamente valoráveis. É certamente uma característica fundamental da espécie humana, que nos distingue (ao menos na complexidade de nossos processos) e que é acionada em tudo o que fazemos. Mas pode ser dirigida para a construção de civilizações como para a organização da guerra e da opressão.

Transformações são feitas, constantemente, pelos processos comunicacionais. $\mathrm{O}$ direcionamento é sempre tentativo, mas não há garantias sobre os objetivos daquilo que se tenta fazer. Por isso mesmo, o desenvolvimento de um conhecimento - de ordem científica, cultural, criativa e pragmática (de senso comum) - é fundamental.

Só o aperfeiçoamento constantemente de nossos conhecimentos sobre a centralidade dessa necessidade e dessa competência humana pode desenvolver a probabilidade de seu direcionamento civilizatório, contra a dispersão aleatória e contra os obscurantismos que recusam ou oprimem, no outro, sua diferença. $\mathrm{O}$ que torna a comunicação positiva é a busca do reconhecimento da alteridade. 


\section{Posfácio - Um diálogo com André Pares}

André Dornelles Pares participou do grupo de pesquisa desde o início, no Seminário de outubro de 2012. À diferença de outros participantes, não trazia um objeto empírico para investigação, mas sim um interesse de estudioso de Filosofia \& Comunicação sobre a heurística em desenvolvimento. Nos debates de seminário, fez observações sobre as apresentações, trazendo aportes para nosso olhar investigativo. Durante a fase de elaboração dos textos, acompanhou sua produção e revisões.

Perto do final dos estudos, nos encaminhou vinte e cinco páginas de observações, perguntas e comentários. A maior parte dessa contribuição escrita não foi incluída nesta publicação porque, justamente, refletindo sobre a heurística em seu estado atual, apresenta questões em angulação filosófica que devem ser pensadas para além do livro.

Por outro lado, além das observações feitas no curso do trabalho, reflexivamente aproveitadas por nós durante o desenvolvimento, alguns dos comentários encaminhados são diretamente produtivos no interior mesmo da obra atual. São questões sobre a heurística e seus objetivos e processos, que não terão sido suficientemente esclarecidas no texto, e pedem um comentário esclarecedor.

Apresentamos neste Posfácio as páginas de André Pares que encaminham essas questões, diretamente voltadas para os processos de geração de conhecimento desenvolvidos na pesquisa. São seguidas por comentário nosso, em que procuramos atender à relevância dos ângulos apresentados. Outras questões do estudo de André Pares, mais abrangentes e exigindo um avanço da reflexão que dependem de estudos posteriores ao livro, serão direcionadoras para minhas pesquisas subsequentes. 


\section{A comunicação social como invenção, tentativa e experiência}

André Dornelles Pares

\section{Ao vivo, o processo comunicacional}

Acabo de chegar do almoço. Nesse par de horas, conversei e fui alvo de conversas tergiversas; obedeci à sinalização de trânsito diretamente e através de ações de terceiros; escolhi o local do almoço pelo contexto da placa que o anunciava, em ajustes com minhas companhias; li jornal impresso, escutei e formulei comentários a partir do publicado nele misturando interpretações de outros estímulos que trouxe ao entrar em contato com seu texto; interagi com o garçom por gestos já há tempo estabelecidos, inferidos por ele a ponto de vir me atender; e, entre outros episódios de interação, fui alvo de transmissão televisiva simultaneamente a um grupo de colegas, tendo esta gerado reações diversas em diferentes graus de intensidade, que impulsionaram, com durabilidade variável e atravessada de sua mensagem posta em circulação, desde o envio de códigos por aplicativo de trocas instantâneas de mensagens via aparelho multifuncional, até inferências provocadas em seguintes processos de interações nos quais se envolveram essas pessoas depois do almoço, entre outras possibilidades infinitas de circuitos de interações - que provavelmente tiveram outras motivações, e foram atravessadas por códigos inerentes a cada novo episódio 
de tentativa de estabelecer comunicação, tendo gerado (mais ou menos) inferências em diferentes graus de pertinência ao dispositivo comunicacional em que cada um estivesse participando.

Como no meu caso, que me inseri num dispositivo de comunicação "conversa conjugal domiciliar" no qual lancei mão de códigos, que naquele contexto julguei os mais compreensíveis, para expressar minha constatação sobre a pertinência da teoria, ainda que intermediária, da comunicação entendida através de uma aposta - em processo de pesquisa - de que ela, a comunicação social, ocorra em dispositivos interacionais e circuitos de circulação. Constatação que tive advinda de minha experiência empírica preparada pelo conhecimento em andamento dessa teoria e pela reflexão ao vivo e reiterada sobre ela, justamente pela profundidade de seu impacto em mim.

Essa teoria, em forma de heurística, ora apresentada como parte do pensamento comunicacional de Braga, faz com que se passe a sentir o quotidiano de maneira a descrevê-lo no formato acima. $\mathrm{Ou}$ seja, a comunicação social entendida dentro do âmbito da ideia de, ou propriamente como, 'interação' - que habita há um tempo a perspectiva braguiana - já coloca o fenômeno comunicacional muito perto, se não dentro, de nossas ações mais corriqueiras. Nessa perspectiva, entende-se de início que não há privilégio aos meios, à tecnologia, à linguagem, ao produto no entendimento científico da comunicação social: segundo Braga, o que interessa são os processos engendrados em interações sociais entendidas sob a ótica comunicacional.

\section{Para encontrar a comunicação na interação: uma heurística como método}

$\mathrm{O}$ ponto que aparece crucial, assim, seria o desafio de descobrir de que modo estes processos interacionais ocorrem, a ponto de podermos identificá-los como comunicacionais. Para enfrentar esse 
problema, Braga oferece como método uma investigação "descritiva e inferencial" "sobre toda uma diversidade de processos sociais segundo uma perspectiva comunicacional" (grifei). Esta maneira de ação, com enfoque na busca de "perguntas e ângulos de observação que se apresentem como mais próximos de preocupações comunicacionais" favoreceria "o desentranhamento de um conhecimento propriamente comunicacional”.

Note-se que para a investigação - que acontece fazendose descrições e inferências de processos sociais (de interação) - se dar "segundo uma perspectiva comunicacional", são necessárias "perguntas e ângulos de observação", o mais próximo possível de "preocupações comunicacionais". Nesse caso, de início, valeria perguntar: já não seria preciso ter de antemão alguma ideia do que seja o 'comunicacional', para que as perguntas e ângulos assim o sejam e permitam enxergar no, e/ou extrair do, processo social uma "perspectiva comunicacional"?

A esse possível problema, Braga diz que será preciso "organizar um conjunto articulado de ângulos e perguntas que favoreçam uma aproximação compreensiva de diferentes situações sociais com um 'olhar comunicacional" (grifei). Novamente, contudo, sente-se que viceja, de algum modo, uma proto-ideia, que seja, de entendimento, suspeita, ou hipótese do que seja o comunicacional, a ponto de se poder identificar, no ângulo de aproximação ou na pergunta que faria aparecer o comunicacional, já um "olhar comunicacional".

É provável que a resposta de Braga, aí, seja a de que podemos "hipotetizar ângulos de observação e perguntas para obter, tentativamente, uma compreensão do processo observado". Isto é, deve haver, antes de fazer perguntas e/ou apontar ângulos (mais ou menos focados), um cuidadoso trabalho ainda de construir, elaborar, criar estas perguntas, com tais características que seriam capazes de desentranhar, dos processos sociais, o comunicacional. De todo o 
modo, não deixa de persistir uma questão, agora em relação a tais características das perguntas e ângulos de observação: quais características são estas, que permitiriam tocar, fazer ver, trazer à tona o que seria entendido como comunicacional? Ou, afinal - ou por princípio! - o que é o comunicacional?, uma vez que ele aparece já 'instalado' quando se faz a pergunta que procura identificá-lo.

$\mathrm{O}$ texto braguiano diz que as respostas obtidas destas perguntas permitiriam comparar as situações sociais investigadas "em sua diversidade, pela angulação comum”. Ou seja, feitas as mesmas perguntas para uma diversidade de processos, se teria a possibilidade de agrupar as situações sociais por indícios encontrados através de um exame que busca o comunicacional. Ainda assim, se vale insistir em direção a um ponto zero da definição, fica a sensação de que 'o comunicacional' ainda tem um momento em que é plantado no processo que o procura descobrir; seja quando aparece como a perspectiva buscada, seja quando surge na característica aproximada pela pergunta que o busca, seja quando brota num conjunto de processos averiguados (justamente naquela perspectiva e através daquelas perguntas).

Neste momento, vale retomar então esta escalada de busca do comunicacional através do método oferecido por Braga, fazendo um refinamento das perguntas de aproximação ao processo investigado. Partindo do entendimento de que há um marco inicial - ao admitir-se que é nos processos sociais de interação que se dá o que se entenderá como comunicacional - poder-se-ia traduzir o movimento de busca de identificação do comunicacional em, pelo menos, três perguntas: (i) O que se está fazendo é apontar, em algo (processo social de interação), aquilo que se quer ver (processo comunicacional)? (ii) O que se está fazendo é apontar para algo (processo social de interação), de modo a descobrir aquilo que se imagina (características, traços que identifiquem o processo 
comunicacional)? e (iii) O que se está fazendo é apontar para algo (processo social de interação), de modo a testar aquilo que se hipotetiza (que possa caracterizar traços que identifiquem tais processos como comunicacionais)?

Provavelmente corresponda ao modelo contido nessa última pergunta aquilo que Braga chama de "tática de aproximação", assumida como sua heurística. Esse movimento seria entendido como uma "tentativa de compreender processos para os quais não temos nenhum algoritmo assegurado" (grifei). Com estes dados, nesse momento poder-se-ia tomar a via de desconfiar que, metodologicamente, uma 'heurística' como método (tentativa de compreender processos...) se coloque como um deus ex machina metodológico no processo de identificação, descoberta, definição do comunicacional. Pelo fato do algoritmo ser entendido como uma estrutura rigorosa que controla processos que só existem em função dele, a sua ausência é uma brecha, para lá, dentro da interação, ou bem encontrar alguma coisa (mutante, inclusive), ou bem jogar alguma coisa (que seja permanente, ou inconstante, ou ao sabor do interesse de quem a coloca, e mais uma infinidade de características possíveis). Isto é, o recurso heurístico permitiria arremessar lá para dentro do processo social de interação algo que o valha (como processo comunicacional). Um dos riscos a se correr, admitindo-se essa perspectiva de entendimento da heurística, é que o processo heurístico de busca vale enquanto valer: encontrar lá o comunicacional.

A questão talvez (ainda) seja: como - sob quais critérios e parâmetros - saberíamos que aquilo que aparece é "comunicacional"?

Se uma possibilidade, como já mencionado, é criar "boas perguntas”, elas seriam feitas para aquilo que já estaria identificado como comunicacional. Essa identificação poderia ser dada em duas leituras. Uma, institucionalmente: está seguro o campo da comunicação, tanto o da prática profissional como - e é o caso aqui - o da 
pesquisa científico-acadêmica. A outra identificação, epistemológica, é que não estaria assegurada - ou esta pesquisa não precisaria estar sendo feita. O caso é que a heurística como método para encontrar o comunicacional tem suas idiossincrasias. Ao ser arremessada a característica lá dentro do processo social de interação, na falta do algoritmo-referência, ela perguntaria para justificar uma resposta que estaria mais ou menos suspeitada de antemão - ainda que não concretizada. E o perigo aí é se aproximar de uma ontologia da comunicação desejando fazer justamente uma sociologia do conhecimento da comunicação. Afinal, foram eleitas pesquisas variadas para que, na atenta pesquisa sobre o que elas fazem, se encontre, extraídas delas, o comunicacional.

Mas já teria sido identificado o que é comunicação, para saber o que é o comunicacional, e dele poder inferir algo? 


\section{A tentativa, a experiência}

José Luiz Braga

André Pares evidencia uma leitura com ótima acuidade para entendimento da heurística - tanto no uso que fez desta no exercício descritivo de abertura, como na observação de nosso encaminhamento metodológico, como ainda nas perguntas, que efetivamente pedem esclarecimento. Algumas dessas perguntas são argumentativas - servindo para André encaminhar a reflexão para questões de fundo, de ordem epistemológica (envolvendo conceitos kantianos, como juízos analíticos a priori e sintéticos a posteriori). Mas podem ser referidas também em modo mais cotidiano, para explicitarmos aspectos que direcionam a heurística e a pesquisa.

Um primeiro ângulo é se tenho ou não uma definição, ou protodefinição, do que seja “comunicação”. André Pares tem razão em perguntar se "já não seria preciso ter de antemão alguma ideia do que seja o 'comunicacional", para elaborarmos a heurística. Não tenho uma identificação do fenômeno com pretensões de rigor epistemológico - não há definição. Mas, sim, tenho uma percepção pragmática, vagamente compartilhada por “todos nós" - que é o que o senso comum entende por comunicação. Nosso senso comum tem uma noção vaga, mas aplicável, sobre o que seja comunicação - e isso não é pouco. Ao contrário, é mesmo extraordinário como conseguimos nos entender a respeito dos processos mais diversos relacionados ao fenômeno, conversando no dia a dia sobre questões, problemas e objetivos comunicacionais. Não servindo como “definição", ainda assim a noção tem servido para a interação entre 
os seres humanos a respeito dos variadíssimos gestos pragmáticos que chamamos de "comunicação".

Mais que isso, a noção tem servido como ponto de partida para pesquisadores das várias ciências humanas e sociais tratarem, em suas áreas, do fenômeno, com seus ângulos diferenciados. Agora, já um pouco mais circunscrito em abrangência e com maior sistematicidade - a de cada disciplina em que se situam. Quando tratam de "comunicação" em sociologia, em linguística, em antropologia, não têm dúvidas de que sabem do que estão falando, e de que serão entendidos por seus leitores - já agora com um pouco mais de rigor e especificidade que no senso comum.

Tais proposições de outras disciplinas sobre o tema também nos servem como referência - embora, evidentemente, dando preferência a alguns ângulos sobre outros. Por isso mesmo, devo refletir sobre a observação de André Pares, de que fazemos "sociologia do conhecimento" - o que implicaria considerar como comunicacional aquilo que os pesquisadores investigam a título de estudos da comunicação.

Sim e não. Sim, porque tais perspectivas existem, e não temos que partir da "estaca zero". Um bom trabalho de sociologia do conhecimento nos oferece um ponto de partida bastante interessante. Não, entretanto, se se significar com a expressão que os processos constatados ("o que os pesquisadores investigam") seriam uma resposta final que nos deixe em repouso, considerando pragmaticamente resolvida a questão "disciplinar" da comunicação. Por isso, embora tenha feito algumas pesquisas para circunscrever temas e perspectivas que colegas da área assumem como pertinentes à comunicação, não faço aí simplesmente uma escolha para me situar em um lugar mais ou menos assegurado. Nosso objetivo é, então, um pouco mais complexo. 
O fato de que a área não tenha uma definição consensual sobre o que seja o comunicacional não implica, portando, desconhecimento. Apenas, o que sabemos está tão entranhado em outros conceitos mais estruturados, das demais CHS, que não sabemos bem o que é próprio da comunicação e o que é próprio dessas outras perspectivas ${ }^{113}$. Assim como avançamos, ao passar do conhecimento de senso comum para os conhecimentos das ciências humanas e sociais, avançaremos mais passando destas a um conhecimento focalizado no fenômeno comunicacional. Não busco uma essência supostamente não percebida pelas demais disciplinas. Busco apenas uma compreensão dos processos enquanto não subsumidos a princípios das ciências sociais estabelecidas. Em vez de essência, busco especificidade.

Trata-se então de observar o que as diferentes áreas de interesse parecem inferir como sendo "de ordem comunicacional", para extrair, nessa diversidade, alguns aspectos mais ou menos comuns a várias áreas de interesse e mesmo a várias disciplinas acadêmicas. Tenho aí, então, uma perspectiva um pouco mais "selecionada" para a construção da heurística (ou seja: para organizar as premissas que apresentamos nos capítulos iniciais). A partir daí, já não estou fazendo sociologia do conhecimento. Busco caminhos de uma "epistemologia evolucionária", conforme visadas construídas no século XX, em diferentes momentos, por Piaget, por Karl Popper, e por Donald T. Campbell.

É nessa perspectiva que devem ser consideradas as três alternativas percebidas por André Pares como possíveis, na aproximação proposta, e das quais ele mesmo observa como mais provável a

113 Os estudos de interface entre comunicação e outra disciplina podem ser produtivos pelo tensionamento sobre a perspectiva da outra área e a busca de um foco comunicacional mais nítido (ver Braga, 2004). 
terceira: ou quero mostrar, na interação social, o processo comunicacional, como já o vejo de antemão; ou quero ali descobrir o que já imagino seja o comunicacional; ou, finalmente, quero testar o que a heurística hipotetiza.

Efetivamente, o grau de descoberta seria crescente, nestes três movimentos. Nulo na primeira alternativa, um pouco maior na segunda e na terceira. Mas acredito poder sugerir um quarto movimento, que complementa o terceiro e faz avançar o sentido heurístico da pesquisa. Aquilo que imagino não aparece na forma de "tentar descobrir o que já sei", nem de apenas confirmar (ou não) a hipótese de que o seja. Mas sim como probabilidade de descobrir alguma coisa para além do que até o momento consigo imaginar seja em substituição, seja em desenvolvimento adicional. Por isso, mesmo assumindo eventuais descaminhos na aproximação (e nas premissas com as quais essa aproximação é feita), podemos assegurar uma produtividade do processo, em termos de conhecimento.

Isso nos leva ao comentário sobre a "sensação de que o comunicacional tem um momento em que é plantado no processo que o pretende descobrir". Este é efetivamente um risco a ser evitado (correspondendo à primeira das três alternativas). Aproveitando a metáfora botânica de André Pares, acredito que não plantamos um arbusto pronto para depois confirmar sua existência. Naquele quarto movimento, apenas colocamos uma raiz híbrida no solo, que esperamos seja rico, da heurística em desenvolvimento - para ver a planta que poderá se desenvolver a partir desse momento. Os nove casos já oferecem resultados estimulantes.

Assim, aquele conjunto de premissas dos capítulos iniciais pode bem ser visto como a minha caracterização (provisória) do que seja o comunicacional. Não é uma definição, não oferece critérios - porque não tem organização, nem estrutura, nem abrangência definida de validade. Algumas premissas certamente não valerão em muitas 
ocorrências do fenômeno. Outras características certamente existirão, que não aparecem ainda entre as premissas. Mas ainda assim, é uma ideia já suficientemente organizada para ser desenvolvida heuristicamente. As premissas compõem uma noção preliminar, tentativamente inferida um pouco além de proposições diversas da área.

O objetivo de "desentranhamento" que tenho defendido em alguns artigos (e nos capítulos iniciais deste livro) implica em não aceitar a dispersão que inevitavelmente tem decorrido da diversidade de ângulos. O objetivo seria, não o de chegar a uma ontologia, mas sim a perspectivas organizadas que viabilizem (em seu espaço de abrangência - de que ainda não sabemos bem a extensão nem o desenho) um relacionamento mais ou menos sistematizado das características que aí ocorrem. Se estas características forem razoavelmente diversificadas e abrangentes, teremos gerado um "campo de forças", atraindo mais algumas características, desenfatizando outras - servindo de algum modo para organizar percepções.

Para que serve, metodologicamente, a heurística? Certamente serve para fazer descrições e inferências. Por exemplo, a excelente descrição feita por André Pares de um "horário de almoço" vivido em Porto Alegre, com que abre seu texto, evidenciando ter apreendido bem a substância principal da proposta.

Há algumas apostas associadas a esse acionamento. Primeiro, que podem ser feitas descrições de ocorrências bastante variadas (creio que os casos empíricos estudados reforçam positivamente esse ângulo da aposta). Depois, que tais descrições sejam pragmaticamente interessantes - isso é, complementem satisfatoriamente a compreensão das ocorrências. Esse aspecto, entretanto, depende das leituras e interpretações sobre o acionamento aqui feito da heurística. Mas a aposta segue adiante, para seu principal objetivo - que é o de, fazendo tais descrições (com variedade e amplitude suficientes), poder inferir outras características, desenvolver melhores 
perguntas, e ainda ampliar o rigor com que venhamos a perceber abrangências e validades referentes à compreensão do fenômeno.

Essa possibilidade de desenvolvermos melhores perguntas e apreender com mais acuidade a abrangência da heurística decorre justamente do que André Pares percebe: "o recurso heurístico permitiria arremessar lá para dentro do processo social da interação” quaisquer características, "ao sabor de quem as coloca". Isso significa que, enquanto de nossa parte preferimos enfatizar tais e tais características como mais frequentemente presentes e mais enfaticamente importantes para compreender a ocorrência do comunicacional, outros pesquisadores podem - em função de suas experiências, de suas pesquisas, de sua formação, de sua acuidade - inferir que outras características o farão melhor, com mais precisão.

Assim, não se trata de pensar "as perguntas certas" (baseadas em uma definição) por oposição a "perguntas erradas" que até agora tivessem sido feitas. Acho mesmo que há um bom número de perguntas disponíveis bastante interessantes - mas acredito que é sempre possível descobrir ainda outras, um pouco melhores.

Isso só é possível quando se trata de características do fenômeno - que são plurais e às quais se podem dar ênfases variáveis, conforme o tipo de processo social que se observa. Se se tratasse da "essência do comunicacional", a possibilidade não existiria - uma pretensão de essência expulsa outra.

Assim, minha percepção não parte de uma essência prefigurada; nem se encaminha na busca de uma essência definidora. Resistimos a uma posição essencialista assumindo, ao invés, uma perspectiva pragmatista e de ordem histórica sobre os processos comunicacionais. Recusar essências não implica, porém, aceitar quaisquer afirmações sobre o fenômeno. Acredito que algumas características são mais abrangentes, pragmaticamente mais relevantes, mais pertinentes para uma situação comunicacional histórica. 
Até o momento, os aspectos tratados no presente livro expressam meu entendimento.

Acredito também que, se cotejarmos essas características com outras, propostas por outros pesquisadores e com outras ênfases, avançaremos, pela teoria metodológica das hipóteses concorrentes (Campbell, 2005), na direção de conhecimentos de maior sabedoria a respeito dos processos comunicacionais que produzimos constantemente e nos quais estamos imersos.

O acompanhamento dado por André Pares a esta pesquisa, as instigantes reflexões nos diversos momentos da elaboração, e os desafios trazidos no comentário aqui apresentado, com a exigência de rigor que sempre oferece, fazem sublinhar a importância da interação e do debate acadêmico, como condição fundamental para o avanço do conhecimento. 


\section{Bibliografia}

Alain. Idées. Introduction à la philosophie - Platon, Descartes, Hegel, Auguste Comte. [1939] Paris: Paul Hartmann, 1947.

Arles, Antonio; Silveira, Sérgio Amadeu da; Pimentel, Tiago. Interagentes: Estudo mostra principais detratores e apoiadores de Dilma nas redes sociais. Revista FóRUM, julho 23, 2013. Disponível em http://www.revistaforum.com.br/blog/2013/07/ interagentes-estudo-mostra-principais-detratores-e-apoiadores-dedilma-nas-redes-sociais/

Austin, John L. How to Do Things with words. Cambridge, Massachusetts: Harvard University Press, 1976, Second Edition, J.O. Urmson and Marina Sbisa, Editors.

Bauman, Zigmunt. O mal-estar da pós-modernidade. Rio de Janeiro: Jorge Zahar, 1998.

. Comunidade: a busca por segurança no mundo atual.

Rio de Janeiro: Zahar, 2003.

. Vida Líquida. Rio de Janeiro: Jorge Zahar, 2007.

Becker, Howard S. Métodos de pesquisa em Ciências Sociais. São Paulo: Hucitec, 1993.

Benevides, Pedro. Publicidade e autoritarismo no Brasil. Tese de Doutoramento, Programa de Pós-graduação em Comunicação da 
Universidade do Vale do Rio dos Sinos, São Leopoldo: Unisinos, 2006.

Berger, Christa. Em torno do discurso jornalístico. In: Fausto Neto (Org.). O indivíduo e as mídias. Rio de Janeiro: Diadorim, 1996, p.188-193.

Birman, Joel. Mal-estar na atualidade: a psicanálise e as novas formas de subjetivação. $2^{\mathrm{a}}$ edição. Rio de Janeiro: Civilização Brasileira, 2000.

Blood, Rebeca. Weblogs and journalism: do they connect? Nieman reports, n.3, v. 57, p. 61-63, 2003.

Bourdieu, Pierre. Da regra às estratégias. In: Coisas Ditas. São Paulo: Brasiliense, 1990 (original: 1987).

. Os usos sociais da ciência - por uma sociologia clínica do campo científico. São Paulo: Editora UNESP, 2003.

Boyd, D. M. \& Ellison, N. B. Social network sites: definition, history and scholarship. Journal of Computer-Mediated Communication, vol. 13, 2007, p.210-230. Disponível em: http://onlinelibrary.wiley. com/doi/10.1111/j.1083-6101.2007.00393.x/full.

Braga, José Luiz. Aprendizagem versus Educação na Sociedade Mediatizada. Revista Geraes - Estudos em Comunicação e Sociabilidade, Belo Horizonte: PPG Comunicação/UFMG, no 53, 2002, p. 26-39. 
. Os estudos de interface como espaço de construção do Campo da Comunicação, Contracampo, vol 10/11, fascículo 2004/2, Niterói: UFF, 2004, p. 219-235.

. A sociedade enfrenta sua mídia - dispositivos sociais de crítica midiática. São Paulo: Editora Paulus, 2006.

. Mediatização como processo interacional de referência. In: Médola, Ana Sílvia; Araujo, Denize Correa; Bruno, Fernanda (orgs.). Imagem, visibilidade e cultura midiática. Livro Compós 2007. Porto Alegre: Sulina, 2007, p. 141-167.

. Comunicação, disciplina indiciária. Matrizes, no 1 , série 2, São Paulo: ECA/USP, 2008, p. 73-88. Disponível em http://www. matrizes.usp.br/index.php/matrizes/article/view/85

. Disciplina ou campo? O desafio da consolidação dos estudos em Comunicação. Ferreira, Jairo, Paoliello Pimenta, Francisco e Signates, Luiz (org.). Estudos de Comunicação: Transversalidades epistemológicas. São Leopoldo: Unisinos, 2010a, p. 19-38.

. Comunicação é aquilo que transforma linguagens. Alceu, vol. 10, série 20, Rio de Janeiro: PUC/Rio, 2010b, p. 41-54.

. Nem rara, nem ausente - tentativa. Matrizes, ano 4, $\mathrm{n}^{\circ}$ 1, jul./dez. São Paulo: ECA/USP, 2010c, p. 65-81. Disponível em: http://www.matrizes.usp.br/index.php/matrizes/article/ view/179/300

. Análise performativa. Cem casos de pesquisa empírica, in Braga, José Luiz, Vassallo de Lopes, Maria Immacolata e Martino, 
Luiz Cláudio (orgs.), Pesquisa Empírica em Comunicação. Livro Compós 2010. São Paulo, Editora Paulus, 2010d, p. 403-423.

. Constituição do Campo da Comunicação. Verso e Reverso, v. 25 (58), jan.-abr (edição revista, anotações de atualização). São Leopoldo: Unisinos, 2011a, p. 62-77. Disponível em: http://revistas. unisinos.br/index.php/versoereverso/article/view/924

. Dispositivos Interacionais, in Anais do XX Encontro Anual da Compós, GT Epistemologias da Comunicação, Porto Alegre: UFRGS, 14 a 17 de junho. Disponível em: http://www.compos.org.br/data/biblioteca_1657.doc, 2011b.

. Uma teoria tentativa. E-Compós, vol. 15, série 3, set./dez, Brasília: Compós, 2012a, p. 1-17. http://www.compos.org.br/seer/ index.php/e-compos/article/view/811/629

. Circuitos versus Campos Sociais. In: Mattos, Maria Ângela; Janotti Junior, Jeder; Jacks, Nilda (orgs.) Mediação \& Midiatização, Livro Compós 2012. Salvador/Brasília: EDUFBA/Compós, 2012b, p. 31-52.

. La política de los internautas es producir circuitos. In Carlón, Mario; Fausto Neto, Antonio (orgs.), Las políticas de los internautas - nuevas formas de participación. Buenos Aires: La Crujía, 2012c, p. 43-59.

. Interação como contexto da comunicação. Matrizes, vol. 1, série 6, São Paulo: USP, 2012d, p. 25-41. 
. Dispositivos \& Circuitos - uma síntese. Paper. Seminário

Dispositivos e Circuitos em Comunicação. São Leopoldo, 2012e.

. O que a comunicação transforma? In Braga, José Luiz;

Ferreira, Jairo; Fausto Neto, Antonio; Gomes, Pedro Gilberto (orgs.).

Dez perguntas para a produção de conhecimento em comunicação. São Leopoldo: Editora Unisinos, 2013, p. 156-171.

. Um conhecimento aforístico. Questões Transversais -

Revista de Epistemologias da Comunicação, vol. 1, série 2, jan./jul. São Leopoldo: UNISINOS, 2014, p. 44-53.

. O grau zero da comunicação. E-Compós, vol. 18, série 2, Brasília: Compós, 2015, p. 1-17.

. Perspectivas para um conhecimento comunicacional .

In Vassallo de Lopes, Maria Immacolata (org.) Epistemologia da

Comunicação no Brasil: trajetórias autorreflexivas. São Paulo: ECA/USP, 2016, p.123-141.

Braga, José Luiz \& Calazans, Maria Regina. Comunicação e Educação - Questões Delicadas na Interface. São Paulo: Hacker Editores, 2001.

Braga, José Luiz; Vassallo de Lopes, Maria Immacolata; Martino, Luiz Cláudio (Org.). Pesquisa empírica em Comunicação. São Paulo: Editora Paulus, 2010.

Braga, Ruy. Sob a sombra do precariado. In: Cidades Rebeldes: Passe Livre e as manifestações que tomaram as ruas do Brasil São Paulo: Boitempo: Carta Maior, 2013. 
Brambila, Ana Maria. Jornalismo open source: discussão e experimentação do OhmyNews International. Dissertação de Mestrado. Porto Alegre: UFRGS, 2006.

Bruck, Mozahir Salomão; Jesus, Eduardo. José Luiz Braga:

Dispositivos interacionais como lugar para dialogar e tensionar conhecimentos. Entrevista em Dispositiva, v. 1, n. 1, jan./jul. Belo Horizonte: PUC/MG, 2012, p. 28-35. Disponível em: http://periodicos.pucminas.br/index.php/dispositiva/article/view/2817/3103.

Campbell, Donald T. Apresentação. In: Yin, Robert K. Estudo de Caso: planejamento e métodos. Porto Alegre: Bookman/Artmed, 2005.

Campbell, Donald T. Epistemología Evolucionista. In Martinez Sergio F. y Olivé Leon (compiladores) Epistemología Evolucionista. México: Paidós, Colección Problemas Cientificos y Filosoficos, Universidad Nacional Autónoma de Mexico, 1997, p.43-103. Disponível em http://www.filosoficas.unam.mx/ sfmar/ publicaciones/MARTINEZ-OLIVE\%201997\%20Epistemologia\%20 Evolucionista.pdf.

Canal Futura. Almanaque das Redes Sociais Futura. Rio de Janeiro: Fundação Roberto Marinho/Canal Futura, 2010.

Casali, Caroline. Circulação de saberes sobre Jornalismo na sociedade em midiatização. Tese de Doutoramento. Programa de Pós-Graduação em Comunicação da Universidade do Vale do Rio dos Sinos. São Leopoldo: UNISINOS, 2014. 
. Comentários sobre pré-estudo de "O Noticiador-

Noticiado", apresentado no Seminário Dispositivos \& Circuitos. Anais do Seminário, 18 e 19 de outubro de 2012.

Castellano, Mayka. Cultura da auto-ajuda: o "surto do aconselhamento" e a bioascese na mídia. E-Compós, vol.15, n. 1, jan./abr. Brasília: Compós, 2012, p. 1-12.

Certeau, Michel de et. all 1. A invenção do cotidiano. 2. Morar, Cozinhar. 10aed. Petrópolis: Vozes, 2011.

. A invenção do cotidiano. A arte de fazer. 19a ed.

Petrópolis: Vozes, 2012.

Christensen, Christian. Wikileaks: Losing Suburbia. Le Monde Diplomatique, English Edition, set. 2011. Disponível em http:// mondediplo.com/blogs/wikileaks-losing-suburbia.

Crossley, Nick \& Roberts, John M. After Habermas, New Perspectives on the Public Sphere. Oxford: Blackwell Publishing, 2004

Deleuze, Gilles. Qu'est-ce qu'un dispositif? In: Michel Foucault philosophe. Rencontre Internationale. Paris 9 a 11 janvier 1988. Paris: Éditions du Seuil, 1989, p.185-193.

. O que é um dispositivo? In: L. Janeira (Ed.), Michel Foucault, filósofo. Barcelona, España: Gedisa, 1990, p. 155-161.

Eco, Umberto. Apocalípticos e integrados. São Paulo: Perspectiva, $1993,5^{\text {a }}$ ed. 
Fausto Neto, Antonio. Será que ele é? Onde estamos? A midiatização de um “discurso proibido". Ícone. Ano 7, n.9, dezembro, Recife: UFPE, 2006a, p. 41-60

. Midiatização: prática social, prática de sentido. Paper. Encontro

Rede Prosul - Comunicação, Sociedade e Sentido, Seminário sobre Midiatização, São Leopoldo: PPGCC/Unisinos, 2006b.

. A midiatização jornalística do dinheiro apreendido:

das fotos furtadas à fita leitora. Comunicação. Veredas, Marília: UNIMAR, v. 1, p. 76-90, 2007a.

. Contratos de leitura: entre regulações e deslocamentos.

Diálogos Possíveis (FSBA), v. 6, Salvador: FSBA, 2007b, p. 27-39.

. Enunciação, autorreferencialidade e incompletude. Revista Famecos, vol. 1, n. 34, dez. Porto Alegre: PUC/RS, 2007c, p. 78-85.

. Ombusdman: A interrupção de uma fala transversal.

Revista InTexto, v. 1, Porto Alegre: UFRGS, 2008a, p. 35-47.

. Fragmentos de uma 'analítica' da midiatização. Revista Matrizes, v. 1, no 2, São Paulo: ECA/USP, 2008b, p. 89-105.

. Mudanças da Medusa? A enunciação midiatizada e sua incompletude. Fausto Neto, Antônio; Gomes, Pedro Gilberto; Braga, José Luiz; Ferreira, Jairo (orgs.). Midiatização e Processos Sociais na América Latina. São Paulo: Paulus, 2008c, p. 83-103.

. Olhares sobre a recepção através das bordas da circulação. XVIII Encontro Compós. Belo Horizonte: Compós, junho de 2009. Disponível em: http://www.compos.org.br/data/biblioteca_1164.pdf 
. As bordas da circulação. Alceu, v. 10, Rio de Janeiro: PUC/ RJ, 2010a, p. 55-69.

. A circulação além das bordas, in Fausto Neto, Antonio e Valdettaro, Sandra (orgs.) Mediatización, Sociedad y Sentido Diálogos entre Brasil y Argentina, Colóquio Mediatización, Sociedad y Sentido, Rosario, Argentina: UNR, agosto de 2010b, p. 2-15.

\section{. Afetações da Midiatização sobre o Ofício Jornalístico:}

Ambiência, identidades, discursividades e processos interacionais. Projeto de pesquisa. Programa de Pós-Graduação da Universidade do Vale do Rio dos Sinos - São Leopoldo: Unisinos. 2010c.

. Transformações do campo jornalístico na sociedade midiatizada: as estratégias de celebração e consagração. MORAES, Dênis de (org.). Mutações do visível - Da comunicação de massa à comunicação em rede. Rio de Janeiro: Pão e Rosas, 2010d, p. 113-128.

. Epistemologia do zigue-zague. In Ferreira, Jairo; Paoliello Pimenta, Francisco José; Signates, Luiz (org.). Estudos de Comunicação: Transversalidades epistemológicas. São Leopoldo: UNISINOS, 2010e, p.79-100.

. Midiatização da enfermidade de Lula: sentidos em circulação em torno de um corpo-significante. Mattos, Maria Ângela; Janotti Junior, Jeder; Jacks, Nilda (org.). Mediação \& Midiatização. Salvador/Brasília: EDUFBA/COMPÓS, 2012, p. 297-321. 
Fechine, Yvana. Tendências, usos e efeitos da transmissão direta no telejornal. In: DUARTE, Elizabeth Bastos \& Castro, Maria Lília Dias de. Televisão: entre o mercado e a academia. Porto Alegre: Sulina, 2006. p. 139-154.

Feenberg, A. Critical theory of technology: an overview. Tailoring biotechnologies. Vol. I, issue I, Winter 2005. pp. 47-64. Disponível em: https://www.sfu.ca/ andrewf/books/critbio.pdf.

Felinto, Erick. Grumpy Cat, Grande Mestre Zen da Geração Digital. Afetos e materialidades da imagem memética, 2013. Disponível em: https://www.academia.edu/3879345/Grumpy_Cat_Grande_ Mestre_Zen_da_Gera\%C3\%A7\%C3\%A3o_Digital_Afetos_e_ Materialidades_da_Imagem_Mem\%C3\%A9tica?auto=download

Ferreira, Jairo. Uma abordagem triádica dos dispositivos midiáticos. Líbero, v. 1, São Paulo: FACASPER, 2006, p. 1-15.

Finguerut, S. \& Sukman, H. (orgs). Fundação Roberto Marinho, 30 anos. Rio de Janeiro: Fundação Roberto Marinho, 2008.

Folquening, Victor. Contrabando cristão nas fronteiras da mídia. Projeto de Pesquisa de Doutoramento. PPG em Ciências da Comunicação da Unisinos, 2011.

Foucault, Michel. "Le jeu de Michel Foucault”. Entrevista dada à revista Ornicar? In: Dits et Écrits, Tome III [1977], 1994, p. 298-329.

Foucault, Michel. The confession of the flesh [1977], entrevista. In Power/Knowledge selected interviews and other writings. 
Edited by Colin Gordon, New York: Pantheon Books, 1980, p. 194-228. Disponível em: http://monoskop.org/images/5/5d/ Foucault_Michel_Power_Knowledge_Selected_Interviews_and_ Other_Writings_1972-1977.pdf

Freitas, Ana. Não é sobre 20 centavos, estúpido. Blog awesome randomness. Disponível em: < http:/ / awe-inspiring-randomness.tumblr. com/post/52896959452/n\%C3\%A3o-\%C3\%A9-sobre-20-centavos -est\%C3\%BApido>.

Freud, S. Análise terminável e interminável. [1937]. Edição Standard Brasileira das Obras Psicológicas Completas de Sigmund Freud. Vol. XII. Imago Editora, Rio de Janeiro, 1970.

Giddens, Anthony. As consequências da Modernidade. São Paulo: Ed. UNESP, 1991.

Ginzburg, Carlo. Sinais: raízes de um paradigma indiciário. In Mitos, emblemas, sinais - morfologia e história [1986]. São Paulo: Companhia da Letras, 1989.

Goldmann, Lucien. O Conceito de Estrutura Significativa na História da Cultura. Dialética e Cultura [1958]. Rio de Janeiro: Paz e Terra, 1967.

Gomes, Pedro Gilberto. A midiatização no processo social. Filosofia e ética da comunicação na midiatização da sociedade. São Leopoldo: Unisinos, 2006.

Gomes, Wilson. Transformações da política na era da comunicação de massa. São Paulo: Editora Paulus, 2004. 
Greenwald, Glenn. Sem Lugar para se Esconder: Edward Snowden, a NSA e a Espionagem do Governo Americano, Rio de Janeiro: GMT Editores, 2014.

GReMS, Centre de Recherches sur l'Education aux Médias. Présentation du colloque "Dispositifs \& Médiation des Savoirs", 1998. http:/www.comu.ucl.ac.be/reco/grems/agenda/dispositif/ presentation.htm

Gusmão, Luís de. O fetichismo do conceito - limites do conhecimento teórico na investigação social. Rio de Janeiro: Topbooks, 2012.

Halupka, Max. The evolution of anonymous as a political actor. Tese de doutoramento defendida no programa de Political Studies, The Flinders University of south Australia Faculty. Disponível em: https://www.academia.edu/1220969/ The_Evolution_of_Anonymous_as_a_Political_Actor.

Henn, Ronaldo Cesar; Höer, Kellen Mendes; Berwanger, Gabriela Inácio. Transformações do acontecimento nas redes sociais: das mobilizações contra a homofobia à crise da dupla sertaneja, Brazilian Journalism Research, vol. 8, n. 1, Brasília: SBPJor, 2012. Disponível em http://bjr.sbpjor.org.br/bjr/article/view/392.

Hjarvard, Stig. Midiatização: conceituando a mudança social e cultural, in Revista Matrizes. Vol. 8, no 1, São Paulo: ECA/USP, 2014a, p. 21-44. Disponível em: http://www.matrizes.usp.br/index.php/ matrizes/issue/view/ISSN\%201982-2073/showToc 
Hjarvard, Stig. A mediatização da cultura e da sociedade. São Leopoldo: Editora Unisinos, 2014b.

Jahn, Carlos Alberto. Indeterminações comunicacionais geradoras de indefinição ética - um estudo de casos múltiplos de dispositivos interacionais, circuitos comunicacionais e lógicas tentativas. Tese de Doutoramento, Programa de Pós-graduação em Comunicação da Universidade do Vale do Rio dos Sinos, São Leopoldo: Unisinos, 2014.

Jenkins, Henry; Ford, Sam; Green e Joshua. Spreadable Media: Creating Value and Meaning in a Networked Culture. New York: NYU Press, 2013.

Kessler, Frank. Notes on dispositif (captado em 04/08/2010) http:// www.let.uu.nl/ Frank.Kessler/personal/notes\%20on\%20dispositif. PDF

Klein, Eloísa. Circuitos comunicacionais ativados pela autorreferência didática no Jornalismo: o caso do Profissão Repórt. Tese de Doutoramento, Programa de Pós-graduação em Comunicação da Universidade do Vale do Rio dos Sinos, São Leopoldo: Unisinos, 2012.

Kuhn, Thomas. A tensão essencial. São Paulo: Editora Unesp, 2011

Kvale, Steinar. Las entrevistas em investigación cualitativa. Madrid: Morata, 2011.

Lasch, Scott. Crítica de la información. Buenos Aires: Amorrortu, 2005. 
Lemos, André. Cibercultura e Mobilidade. A Era da Conexão. Trabalho apresentado no XXVIII Congresso Brasileiro de Ciências da Comunicação, Rio de Janeiro: UERJ, 5 a 9 de setembro de 2005.

Lima, Venício A. de. As manifestações de junho e a mídia. Teoria e debate. Edição 113. 19 junho 2013. Disponível em http://www.teoriaedebate.org.br/colunas/midia/manifestacoes-de-junho-e-midia

Machado, Michelli. A midiatização da narrativa histórica em minisséries da rede Globo. Tese de Doutoramento, Programa de Pós-graduação em Comunicação da Universidade do Vale do Rio dos Sinos, São Leopoldo: Unisinos, 2013.

Marcondes Filho, Ciro. Duas doenças infantis da comunicação: a insuficiência ontológica e a submissão à política. Uma discussão com José Luiz Braga. Matrizes, Ano 5, no 1, ago./dez. São Paulo: ECA/ USP, 2011a, p. 169-178. Disponível em: http://www.matrizes.usp.br/ index.php/matrizes/article/view/205/pdf.

Martín-Barbero, Jesús. Uma aventura epistemológica. Entrevista a Maria Immacolata Vassallo de Lopes. Matrizes, v. 2, n. 2, jul./dez. São Paulo: ECA/USP, 2009, p. 143-162.

Martino, Luiz Cláudio. Uma questão prévia: existem teorias da comunicação? In Martino, Luiz Cláudio (Org.) Teorias da Comunicação - muitas ou poucas? São Paulo: Atelier Editorial, 2007, p. 13-42.

Medeiros Batista, Ana Lúcia. Noticiador-Noticiado: Perfis de jornalistas numa sociedade em midiatização. Tese de Doutoramento, 
PPG em Comunicação da Universidade de Brasília. Brasília: UnB, 2013.

Melo, Paula. Tensões entre Fonte e Campo Jornalístico: um estudo sobre o agendamento mediático do MST. Tese de Doutoramento, Programa de Pós-graduação em Comunicação da Universidade do Vale do Rio dos Sinos, São Leopoldo: Unisinos, 2008.

Melo, Paula. Comentários sobre pré-estudo de O NoticiadorNoticiado, apresentado no Seminário Dispositivos \& Circuitos. Anais do Seminário, 18 e 19 de outubro de 2012.

Merleau-Ponty, Maurice. A prosa do mundo. São Paulo: Cosac Naify, 2007 [1964, obra póstuma editada por Claude Lefort].

Merton, Robert K. Social Theory and Social Structure [1949]. New York: The Free Press, 1968.

Miège, Bernard. O Pensamento Comunicacional. Petrópolis: Vozes, 2000.

. A Sociedade Tecida pela Comunicação: Técnicas da informação e da comunicação entre inovação e enraizamento social. São Paulo: Paulus, 2009a.

. O pensamento comunicacional na contemporaneidade.

Líbero, v. 12, n. 23, jun. São Paulo: FACASPER, 2009b, p. 9-18. 
. Comunicação e tecnologia na sociedade: uma dimensão transversal. Entrevista. Matrizes. Ano 3 - no 1 ago./dez. São Paulo: ECA/USP, 2009c, p. 121-127.

Morin, Edgard. Cultura de Massa no Século XX. Rio de Janeiro: Forense Universitária, 1990.

Nichols, Bill. Introdução ao documentário. Campinas, SP: Papirus, 2005.

Nobre, Marcos. Choque de democracia - Razões da revolta. São Paulo: Companhia das Letras, 2013.

Pereira de Sá, Simone e Holzbach, Ariane. "\#u2youtube e a performance mediada por computador”. GT Comunicação e Cibercultura do XIX Encontro da Compós, Rio de Janeiro: Compós, jun. 2010.

Piaget, Jean. Introduction à l'epistémologie génétique, Paris : Presses Universitaires de France, Coll. Que-sais-je, 2005 [1970].

Pires, Álvaro. [1997]. De quelques enjeux épistémologiques d'une méthodologie générale pour les sciences sociales. Coll. Les classiques des sciences sociales, Québec: Université du Québec, 2006. Disponível em: http://classiques.uqac.ca/contemporains/pires alvaro/quelques_enjeux_epistem_sc_soc/enjeux_epistem_sc_soc. html

Popper, Karl. La selección natural y El surgimiento de la mente. In Martinez Sergio F. y Olivé Leon (compiladores) Epistemología Evolucionista. México: Paidós, Colección Problemas Cientificos y Filosoficos, Universidad Nacional Autónoma de Mexico, 1997, p. 
25-42. Disponível em http://www.filosoficas.unam.mx/ sfmar/ publicaciones/MARTINEZ-OLIVE\%201997\%20Epistemologia\%20 Evolucionista.pdf.

. All life is problem solving. London, Routledge, 1999. Tradução em português: Popper, Karl. A vida é aprendizagem: epistemologia evolutiva e sociedade aberta. Lisboa: Edições 70, 2001.

. O Mito do Contexto: em defesa da ciência e da racionalidade. Lisboa: Edições 70, 2009.

. A lógica da pesquisa científica. São Paulo: Cultrix, 2013.

Raffnsoe, Sverre. Qu'est-ce qu'un dispositif? L'analytique sociale de Michel Foucault, Symposium, Canadian Society for Continental Philosophy, v. 12, n. 1, 2008, p. 44-66.

Recuero, Raquel. Weblogs, Webrings e Comunidades Virtuais. (UFBA), v. 1, n. 31, 2003, p. 1-5. Disponível em http://www.pontomidia.com.br/raquel

. As Redes Sociais na Internet e a Conversação em Rede. In: Ciseco. Disponível em: http://www.ciseco.org.br/index.php/ artigos/108-as-redes-sociais-na-internet-e-a-conversacao-em-rede.

Rodrigues, Adriano Duarte. Estratégias da Comunicação. Lisboa: Presença, 1990.

. O paradigma comunicacional - história e teorias.

Lisboa: Fundação Calouste Gulbenkian, 2011. 
Seminário. Dispositivos \& Circuitos em Comunicação, Anais. São Leopoldo: Unisinos, outubro de 2012, 284 p.

Shifman, Limor. Memes in digital culture. Massachusetts Institute of Technology, 2014.

Sibília, Paula. O show da vida íntima na internet: blogs, fotologs, videologs, Orkut e webcams. In: Caiafa, Janice; Elhajji, Mohammed. (Org.). Comunicação e sociabilidade: cenários contemporâneos. Rio de Janeiro: Mauad X, 2007, p. 181-199.

Silva, José Henrique P. O 'Estadão’ e a cobertura dos protestos.

Observatório da Imprensa. 18/06/2013, edição 751. Disponível em http://observatoriodaimprensa.com.br/caderno-da-cidadania/_ ed751_o_estadao_e_a_cobertura_dos_protestos/

Silveira, Sérgio Amadeu da: O Fenômeno Wikileaks e as Redes de Poder, Contemporânea - Revista de Comunicação e Política, vol. 9, N. 2, Salvador: UFBA, 2011. Disponível em http://www.portalseer.ufba.br/index.php/contemporaneaposcom/.

Sperber, Dan e Wilson, Deirdre. La pertinence. In: Ludwig, Pascal. Le Langage. Paris: Flammarion, 1997.

Tisseron, Serge. L’intimité surexposée. Paris: Ramsay, 2001.

Valles, Miguel S. Entrevistas cualitativas. Madrid: Centro de Investigaciones Sociológicas, 2002.

Verón, Eliseu. Interfaces. Sobre la democracia audiovisual evolucionada, in: Ferry, Jean-Marc; Wolton, Dominique. El nuevo espacio 
público, Barcelona: Gedisa. 1998, pp. 124-139. Disponível em: http://scholar.google.com.br/scholar?q=Interfaces+sobre+la+democracia+audiovisual+evolucionada\&hl=pt-BR\&btnG=Pesquisar\&lr.

Verón, Eliseu. Quando ler é fazer - a enunciação no discurso da imprensa escrita. In Verón, Eliseu, Fragmentos de um tecido, São Leopoldo: Editora UNISINOS, 2004.

Wilson, Deirdre e Sperber Dan. L'interprétation des ennoncés. Communications nº 30, Paris, 1979.

Xavier, Monalisa Pontes. A Consulta transformada: experimentações de dispositivos interacionais "psi" na sociedade em midiatização. Tese de Doutoramento, PPG em Ciências da Comunicação, Universidade do Vale do Rio dos Sinos, São Leopoldo: UNISINOS, 2014.

Zilhão, António. Verbete "Abdução". In: Branquinho, João; Murcho, Desidério e Gomes, Nelson Gonçalves. Enciclopédia de Termos Lógico-Filosóficos. São Paulo: Martins Fontes, 2006.

Zucolo, Rosana C. Dispositivos interacionais e interações midiatizadas: um estudo sobre a implementação do Projeto Maleta Futura, Canal Futura, em Santa Maria e Passo Fundo/RS. Tese de Doutoramento, Programa de Pós-graduação em Comunicação da Universidade do Vale do Rio dos Sinos, São Leopoldo: Unisinos, 2014. 


\section{Os autores}

\section{Ana Lúcia Medeiros}

Doutora em Comunicação pela UnB (2013), com estágio doutoral na Université de Rennes-1 - França, tendo defendido a tese "Noticiador-Noticiado: perfis de jornalistas numa sociedade em midiatização”. Mestre em Comunicação pela UnB (1999). Graduada em Comunicação/Jornalismo pela Universidade Federal da Paraíba (1988), com Aperfeiçoamento em Teoria da Comunicação pela Universidade Federal da Bahia (2000). Fez Estudos pós-doutorais na Universidade Federal da Bahia em 2015. Foi professora na Universidade Católica de Brasília (1999-2006) e professora substituta na Universidade de Brasília (2006-2008). Em suas atividades acadêmicas, foi idealizadora e coordenadora das agências de comunicação OPN (UCB - 2000-2006) e Facto (UnB - 2006-2008). Foi também repórter colaboradora do Jornal da USP (2002-2006) e Ombudsman (Secom/UnB - 2008). É pesquisadora DCR (CNPq/Fapesq), editora convidada de "Âncora - revista latino-americana de jornalismo" do Laboratório de Jornalismo e Editoração (Laje/CCTA-UFPB). Áreas de interesse: midiatização, televisão e mídias digitais.

\section{André Dornelles Pares}

Professor de Filosofia e de Sociologia no Ensino Médio, atualmente no Colégio Farroupilha e no Colégio de Aplicação da UFRGS, e jornalista. Mestre em Comunicação pela Unisinos (2009), com a dissertação "Através da Imagem: Tarkovski, da Vinci, e a comunicação imagética no âmbito da midiatização". Graduado em Jornalismo pela Unisinos (2005) e em Filosofia pela UFRGS (2007). Foi professor de Filosofia e de Sociologia e Coordenador da área de 
Ciências Humanas na Rede Metodista de Educação. Presidente da A.L.F., Associação dos Licenciados em Filosofia, em Porto Alegre. Faz parte dos comitês científicos da Olimpíada Latinoamericana de Filosofia e da Olimpíada de Filosofia do Rio Grande do Sul. É articulador do GAF - Grupo Autônomo de Filosofia. Recebeu o Prêmio P. F. Gastal de Crítica de Cinema do Concurso Nacional da Secretaria de Cultura de Porto Alegre. Pesquisa sobre Pensamento Latinoamericano.

\section{Caroline Casali}

Professora Adjunta do Departamento de Administração da Universidade Federal de Pelotas (UFPel), desde novembro de 2015. É Doutora em Ciências da Comunicação pela UNISINOS (2014), apresentando a tese "Circulação de saberes sobre Jornalismo na sociedade em midiatização". Mestre em Ciências da Comunicação também pela UNISINOS (2006), com a dissertação "Revistas: configuração do relacionamento entre homem e mulher como estratégia de segmentação do público". Graduada em Comunicação Social / Jornalismo pela UFSM (2004). Foi Professora Adjunta do Departamento de Ciências da Comunicação da Universidade Federal de Santa Maria (UFSM), campus Frederico Westphalen/RS, de 2006 a 2015, atuando nos Cursos de Jornalismo e Relações Públicas. Pesquisa nas áreas de midiatização, marketing, semiótica e estudos de gênero.

\section{Eloísa Joseane da Cunha Klein}

Professora da Universidade Federal do Pampa (Unipampa), campus São Borja. Foi professora da Universidade Federal do Rio Grande do Norte. Doutora em Ciências da Comunicação pela Universidade do Vale do Rio dos Sinos (Unisinos), como bolsista do Conselho Nacional de Desenvolvimento Científico e Tecnológico (CNPq). Mestre em Ciências da Comunicação pela Unisinos. Graduada em 
Jornalismo pela Universidade Regional do Noroeste do Estado do Rio Grande do Sul (Unijuí). Experiência como jornalista em jornais, na Revista Informação (Sinpro-Noroeste) e em assessoria de imprensa. Tem especialização em Humanidades, foco em Sociologia, pela Unijuí. Interesses de pesquisa: teoria e pesquisa em Comunicação; aprendizagem social e mídia; audiovisual; telejornalismo; cultura e tecnologia; redes sociotécnicas; reportagem; jornalismo e conhecimento via processos audiovisuais; autorreferencialidade; aspectos pedagógicos do jornalismo e experiência de construção social de noções sobre o jornalismo, mídia e comunicação; midiatização; mídias digitais; circulação; jornalismo alternativo; assessoria de comunicação; produção informativa institucional e pessoal em mídias sociais.

\section{José Luiz Braga}

Professor Titular no Programa de Pós-Graduação em Ciências da Comunicação da Unisinos desde 1999. Pesquisador PQ 1A do CNPq. Doutor pela Université de Paris II, Institut Français de Presse, onde defendeu a tese "O Pasquim - hebdo brésilien d'humour” (1984). Mestre em Educação pela Florida State University (1972). Especialização em Ciências Políticas pela Université de Toulouse, França (1965) e em TV Educativa, Produção e Direção de TV pelo Instituto de Pesquisas Espaciais (Inpe, 1970). Graduado em Ciências Jurídicas e Sociais pela Faculdade de Direito do Vale do Paraíba (1962). Estudos pós-doutorais na UFMG (2008). Foi professor na Universidade Federal da Paraíba (UFPB) e na Universidade de Brasília (UnB). Foi presidente da Compós, gestão 1993-95. Coordenou o PPG em Ciências da Comunicação da Unisinos (2002-2004). Principais áreas de interesse: métodos de pesquisa em comunicação; crítica mediática; midiatização e processos sociais. 


\section{Leon Rabelo}

Doutorando em Comunicação na Universidade de Brasília, pesquisando o tema "Dados abertos no LabHacker da Câmara dos Deputados: iniciativas de transparência no legislativo federal brasileiro”. Mestre em Comunicação pela Universidade Federal de Goiás (2012). Fez a graduação em Música na UNIFIAM - FAAM, São Paulo (1996). Foi empreendedor próprio em "AdaSist Informática" de 1999 a 2007, produtor cultural em "Musicata Produções" de 2006 a 2009. É tradutor e intérprete em sueco e inglês. Trabalhou em consultoria e produção em projetos de intercâmbio internacional. Pesquisa nas áreas de comunicação e política, comunicação e democracia e novas tecnologias de informação e comunicação.

\section{Maria Regina Zamith Calazans}

Mestre em Tecnologias Educacionais pelo Instituto de Pesquisas Espaciais (INPE) onde foi pesquisadora em TV Educativa, no Projeto SACI, produzindo programas radiofônicos e televisuais. Tem o Diplôme de l'Institut Français de Presse (Université de Paris II - 1981), e o Diplôme d'Études Appronfondies (D.E.A.) em Cinema pela Université de Nanterre, França (1984). Graduada em História pela Universidade de São Paulo (USP). Foi professora na Universidade Federal da Paraíba (UFPB) e na Universidade de Brasília (UnB). Dedica-se ao ensino e à pesquisa de imagens e processos audiovisuais. Áreas de interesse: imagem, literatura.

\section{Michelli Machado}

Editora na Comunicação Institucional da Universidade do Vale do Rio dos Sinos - Unisinos, desde 2013. É doutora em Comunicação pela Unisinos (2013), tendo defendido a tese "A midiatização da narrativa histórica em minisséries da rede Globo". Mestre em Comunicação e Informação pela UFRGS (2006) e Graduada 
em Comunicação Social / Jornalismo, pela Unisinos (2003). Foi Coordenadora do Núcleo de Produção Audiovisual de aulas EaD na TV Unisinos em 2012 e Pesquisadora no Observatório Iberoamericano de Ficção Televisiva (OBITEL) de 2010 a 2012. Tem experiência nas áreas de redação e reportagem, entrevista jornalística, roteiros audiovisuais, produção televisiva, assessoria de imprensa e jornalismo cultural. Tem atuado principalmente nos seguintes temas: ficção televisiva, midiatização e identidade cultural.

\section{Monalisa Pontes Xavier}

Professora Adjunta da Universidade Federal do Piauí (UFPI), no curso de Psicologia, desde 2010 e no Programa de Pós-Graduação em Comunicação desde 2014. É Doutora em Comunicação pela Unisinos (2014), tendo defendido a tese "A Consulta transformada: experimentações de dispositivos interacionais 'psi' na sociedade em midiatização". Mestre em Psicologia pela Universidade Federal do Ceará (2009) e Graduada em Psicologia pela UFC (2006). Foi professora do curso de Psicologia da Faculdade Leão Sampaio, 2009-2010. Na área da Comunicação faz pesquisas sobre mídia e produção de subjetividade; processos de subjetivação na contemporaneidade; e midiatização e processos sociais.

\section{Paula Reis Melo}

Professora Adjunta do Departamento de Comunicação Social da Universidade Federal de Pernambuco (UFPE) desde 2009. Doutora em Ciências da Comunicação pela UNISINOS (2008), com a tese "Tensões entre fonte e campo jornalístico: um estudo sobre o agendamento mediático do MST", tendo feito Estágio Doutoral na Universidade Nova de Lisboa (2006 a 2007). Mestre em Comunicação Rural e Administração Rural pela UFRPE (2000). Graduada em Comunicação / Jornalismo pela UFPE (1996). Foi 
Chefe de Departamento na UFPE de 2011 a 2015. Foi Professora do Departamento de Comunicação Social da Universidade Católica de Pernambuco de 2002 a 2009, onde coordenou o Curso de Jornalismo. Professora e Coordenadora do Curso de Jornalismo das Faculdades Barros Melo (AESO) em 2001. Assessora de comunicação do Centro de Desenvolvimento Agroecológico Sabiá, em 2000. Pesquisa nas áreas de midiatização; comunicação e política; discursos de resistência.

\section{Pedro Benevides}

Professor adjunto de Jornalismo da Universidade Federal da Paraíba, UFPB, desde 2014. Doutor em Ciências da Comunicação pela Unisinos (2006). Mestre em Comunicação pela UnB (2001). Graduado em Comunicação / Jornalismo pela UnB (1999). Fez Pós-Doutorado na Unisinos, de 2011 a 2014. Pesquisa nas áreas de jornalismo, comunicação, e cultura e sociedade.

\section{Rosana Cabral Zucolo}

Professora no Centro Universitário Franciscano, Unifra (desde 2005); Doutora em Ciências da Comunicação pela Unisinos (2014), com a tese "Dispositivos interacionais e interações midiatizadas: um estudo sobre a implementação do Projeto Maleta Futura, Canal Futura, em Santa Maria e Passo Fundo/ RS”. Mestre em Educação (1990). Graduada em Comunicação / Jornalismo (1984) pela UFSM. Professora pesquisadora no curso de especialização Mídias na Educação (EAD/UFSM/ 20092011). Coordenadora do curso de jornalismo na Faculdade Social da Bahia (2001-2005). Professora na Universidade do Vale do Rio dos Sinos (2000-2003) e na Universidade de Passo Fundo (1998-1999). Consultora ad hoc do INEP/MEC. Coordenadora de Comunicação na Fundação de Ciência e Tecnologia do RS 
(2000-2001). Coordenadora de Comunicação na UFSM (19971998). Pesquisa midiatização, comunicação comunitária, discurso científico e a interface comunicação e educação. 


\section{Sobre o Livro}

\section{Capa Erick Ferreira Cabral}

Projeto Gráfico/Editoração Jefferson Ricardo Lima Araujo Nunes

Tipologias Utilizadas Myriad Pro 14 pt

Arno Pro 12 pt

Formato $15 \times 21 \mathrm{~cm}$

Impressão Gráfica UEPB 